\title{
Um Procedimento para Escolha de Pacote de Software na Área de Sistemas de Informação
}

\author{
Jusane Farina Lara
}

Orientadora: Profa. Dra. Rosely Sanches

Dissertação apresentada ao Instituto de Ciências Matemáticas e de Computação - ICMC-USP, como parte dos requisitos para obtenção do título de Mestre em Ciências - Área: Ciências de Computação e Matemática Computacional. 
Aos meus pais Idelar e Lenir, e, ao meu marido Marco Antonio 


\section{Agradecimentos}

Primeiramente, a Deus, por ter me capacitado a realizar este trabalho e ter me confortado nos momentos mais difíceis.

À Prof ${ }^{2} \mathrm{Dr}^{2}$ Rosely Sanches pela orientação deste trabalho e por estar sempre transmitindo muitos ensinamentos, incentivo, dedicação, amizade e paciência.

Ao meu marido Marco Antonio, por estar sempre presente, incentivando, transmitindo segurança e principalmente sendo a minha fonte de paz e tranqüilidade.

À minha familia, meus pais Idelar e Lenir e aos meus irmãos Jucemar e Jane por acompanhar-me, incentivar-me e principalmente, dedicar-me tanto carinho.

À Sra. Hilda pelo carinho, dedicação e hospedagem em sua casa durante todo o tempo de mestrado.

Às amigas Andrezza, Flávia, Huei, Mayb, pelo carinho, amizade, companheirismo, e pelos momentos de reflexão.

Aos companheiros do LABES pela simpatia, amizade e prestatividade.

A todos os professores do ICMC que sempre me incentivaram e se dedicaram pela minha formação profissional, além de estarem sempre dispostos a nos ajudar em tudo.

A todos os funcionários do ICMC, em especial à Beth, à Marília, à Laura e as bibliotecárias que sempre foram muito prestativas e amigas.

À Cantina Famiglia Dall'Agnoll que tornou possivel a realização do estudo de caso 1.

Ao Setor de Recursos Humanos da UNOESC que tornou possível a realização do estudo de caso 2.

À CAPESIPICDT, UNOESC - Campus de Chapecó (SC) e URI - Campus de Frederico Westphalen (RS) pelo apoio financeiro. 


\section{Sumário}

CAPÍTULO 1 - Introdução 1

1.1 - Motivação 1

1.2 - Objetivos

1.3 - Organização do Trabalho ___ 5

CAPÍTULO 2 - A Visão do American Supplier Institute (ASI) do QFD

2.1 - Considerações Iniciais___ 7

2.2 - Desdobramento da Função Qualidade "Tradicional” (QFD-Tradicional) ___ 7

2.3 - As Matrizes do QFD (ASI) _ 10

2.4 - A Matriz Casa da Qualidade __ 13

2.5 - Considerações Finais___ 24

CAPÍTULO 3 - Modelos de Avaliação da Qualidade de Produtos de Software ___ 25

3.1 - Considerações Iniciais _ 25

3.2 - Norma ISO/IEC 9126 - Qualidade de Produtos de Software __ 26

3.3 - Norma NBR 12119 - Qualidade de Pacotes de Software__ 30

3.3.1 Descrição do Produto 31

3.3.2 Manual do Usuário $\longrightarrow 35$

3.3.3 Programas e Dados 35

3.4 - Considerações Finais __ 36

CAPÍTULO 4-Processo de Aquisição de Conhecimento _

4.1 - Considerações Iniciais___ 37

4.2 - Aquisição de Conhecimento __ 37

4.3 - Processo de Aquisição de Conhecimento IPAIA__ 40

4.4 - Considerações Finais___ 45

CAPÍTULO 5 - Estratégia para Elaboração da Matriz Casa da Qualidade ___ 47

5.1 - Considerações Iniciais___ 47

5.2 - Processo de Aquisição de Conhecimento IPAIA, Instanciado para o Domínio QFD Casa da Qualidade _47

5.3 - Estratégia para Elaboração da Matriz Casa da Qualidade __ 61

5.4 - Considerações Finais _ _ 65

CAPÍTULO 6-Um Procedimento para Escolha de Pacote de Software ___ 67

6.1 - Considerações Iniciais___ 67

6.2 - Introdução

6.3 - Definição de Requisitos de Qualidade de Pacote de Software___ 68

6.4 - Preparação da Avaliação de Pacote de Software ___ 69

6.4.1 - Seleção de Métricas de Qualidade 69

6.4.2 - Definição dos Níveis de Pontuação 70 
6.4.3 - Definição dos Critérios de Julgamento 76

6.5 - Procedimento de Avaliação de Pacote de Software 77

6.6 - Considerações Finais 77

CAPÍTULO 7 - Estudos de Caso da Utilização do Procedimento para Escolha de Pacote de Software

7.1 - Considerações Iniciais 79

7.2 - Caso 1 - Cantina Famiglia Dall'Agnol 79

7.2.1 - Elaboração da Matriz Casa da Qualidade 80

7.2.2 - Avaliação do Pacote de Software - Cantina 91

7.3 - Caso 2 - Recursos Humanos (Unoesc)

7.3.1 - Elaboração da Matriz Casa da Qualidade

7.3.2 - Avaliação do Pacote de Software - Recursos Humanos 97

7.4 - Considerações Finais 115

CAPÍTULO 8-Conclusões 117

8.1 - Conclusões 117

8.2 - Contribuições deste Trabalho 118

8.3-Trabalhos Futuros 119

REFERÊNCIAS BIBLIOGRÁFICAS 121

BIBLIOGRAFIA COMPLEMENTAR 125

A - Quality Function Deployment Tool (QFDT) 127 


\section{Lista de Figuras}

Figura 1.1 - Overview do TQM [Haag, 1996] ___ 3

Figura 1.2 - Procedimento para Escolha de Pacote de Software ___ 4

Figura 2.1 - Relação entre QFD, QD e QFDr 10

Figura 2.2 - Modelo do ASI [ASI, 1995]___ 11

Figura 2.3 - Conversão do Mundo dos Clientes para o Mundo da Tecnologia __ 12

Figura 2.4-Casa da Qualidade [Carvalho, 1997] ___ 14

Figura 2.5 - Diagrama de Kano [Kano, 1984] ___ 16

Figura 2.6 - Conversão da Voz do Cliente em Requisitos do Cliente [Cheng, 1995] __ 17

Figura 2.7 - Procedimento para traduzir a voz dos clientes em informações de projeto [Cheng, 1995] __ 23

Figura 3.1 - As seis caracteristicas de qualidade de um software ___ 26

Figura 3.2 - Requisitos de Qualidade da norma NBR 12119 (1996) ___ 31

Figura 4.1-Processo de Aquisição de Conhecimento IPALA [Jubileu, 1999] ___ 41

Figura 5.1 - Processo de Aquisição de Conhecimento IPALA Instanciado __ 48

Figura 5.2 - Fase 1 do Processo de Aquisição de Conhecimento IPALA Instanciado __ 49

Figura 5.3 - Primeiro Ciclo de Aquisição de Conhecimento IPALA Instanciado ___ 51

Figura 5.4 - Segundo Ciclo de Aquisição de Conhecimento IPALA Instanciado __ 59

Figura 5.5 - Partes da matriz Casa da Qualidade - Requisitos do Cliente e o seu Grau de Importância___62

Figura 5.6 - Partes da matriz Casa da Qualidade - Caracteristicas de Pacote de Software ___ 63

Figura 5.7 - Partes da matriz Casa da Qualidade - Matriz de Relacionamentos ___ 64

Figura 5.8 - Partes da matriz Casa da Qualidade - Geração do Grau de Importância __ 65

Figura 6.1 - Modelo de Processo de Avaliação Adaptado da norma [NBR ISO/IEC 9126, $19941 \_68$

Figura 7.1 - . Matriz Casa da Qualidade - Cantina___ 89

Figura 7.2 - Matriz Casa da Qualidade - Recursos Humanos __ 107

Figura A.1 - Exibição da Interface Gráfica Principal __ 128

Figura A.2 - Escolha da opção para acessar informações do "File" 128

Figura A.3 - Escolha da opção para acessar informações do "Item"__ 129

Figura A.4 - Interface Gráfica das informações "Quality" __ 129

Figura A.5 - Interface Gráfica das informações "Element” 130

Figura A.6 - Escolha da opção para acessar informações do "Chart" __ 130

Figura A. 7 - Interface Gráfica das informações "Quality Planning”___ 131

Figura A.8 - Interface Gráfica para Determinar os Relacionamentos __ 131

Figura A.9 - Interface Gráfica entre os relacionamentos _ـ 132

Figura A.10 - Escolha da opção para acessar informações do "Tool" 132

Figura A.11 - Edição da matriz Casa da Qualidade ___ 133 


\section{Lista de Quadros}

Quadro 2.1 - Exemplos de visões de qualidade [Cheng, 1995]

Quadro 2.2 - Procedimento para elaboração da tabela de desdobramento dos requisitos do cliente

[Cheng, 1995] 18

Quadro 5.1 - Estrutura do Plano para a Sessão de Brainstorming Estruturado 53

Quadro 5.2 - Listagem de Idéias 55

Quadro 5.3 - Estrutura do Plano para a Sessão de Entrevista Estruturada 60

Quadro 6.1-Requisitos de Qualidade de Pacote de Software 69

Quadro 6.2-Métricas para Medição de Pacote de Software - Descrição do Produto 71

Quadro 6.3-Métricas para Medição de Pacote de Software - Manual do Usuário 73

Quadro 6.4-Métricas para Medição de Pacote de Software - Programas e Dados 74

Quadro 6.5 - Exemplos de Métricas para Medição de Pacote de Software 75

Quadro 6.6 - Comparação das Necessidades do Cliente versus Pacotes Avaliados 76

Quadro 7.1 - Plano para a Sessão de Brainstorming - Cantina 81

Quadro 7.2 - Estrutura do Plano para a Sessão de Entrevista Estruturada - Cantina 86

Quadro 7.3 - Proce dimento para obter o Grau de Importância das Caracteristicas de Pacote 88 Quadro 7.4 - Avaliação do Pacote de Software - Cantina 92

Quadro 7.5 - Comparação das Necessidades do Cliente versus Avaliação do Pacote da Cantina 96

Quadro 7.6 - Plano para a Sessão de Brainstorming - Recursos Humanos 98

Quadro 7.7-Estrutura do Plano para a Sessão de Entrevista Estruturada-Recursos Humanos 104

Quadro 7.8 - Procedimento para obter o Grau de Importância das Características de Pacote 106

Quadro 7.9 - Avaliação do Pacote de Software - Recursos Humanos 110

Quadro 7.10 - Comparação das Necessidades do Cliente versus Avaliação do Pacote do Recursos Humanos 114 


\section{Lista de Tabelas}

Tabela 5.l - Obtenção da Voz dos Clientes.____ 54

Tabela 5.2 - Tabela de Desdobramento dos Requisitos do Cliente (TDRC) _ _ _ 57

Tabela 7.l - Obtenção dos Dados Originais - Cantina _____ 83

Tabela 7.2 - Tabela de Desdobramento dos Requisitos do Cliente - Cantina__ 85

Tabela 7.3 - Tabela de Desdobramento dos Requisitos do Cliente como Grau de Importância-Cantina_87

Tabela 7.4 - Geração do Grau de Importância em Percentagem - Cantina ___ 90

Tabela 7.5 - Obtenção dos Dados Originais - Recursos Humanos _____________ 100

Tabela 7.6 - Tabela de Desdobramento dos Requisitos do Cliente - Recursos Humanos______ 103

Tabela 7.7 - Tabela de Desdobramento dos Requisitos do Cliente com o Grau de Importância-Recursos

Humanos

105

Tabela 7.8 - Geração do Grau de Importância em Percentagem - Recursos Humanos 108 


\section{Resumo}

Diante das inúmeras opções de pacotes de software que existem atualmente para as aplicações de Sistemas de Informação e da dificuldade que um cliente tem para escolher aquele pacote que atenda melhor suas necessidades, neste trabalho é apresentado um procedimento para escolha de pacote de software na área de Sistemas de Informação. Nesse procedimento são utilizadas a norma NBR 12119 da Associação Brasileira de Normas Técnicas (ABNT) e o Quality Function Deployment QFD do American Supplier Institute (ASI). Também são apresentados dois estudos de caso da aplicação do procedimento para escolha de pacote de software. 


\section{Abstract}

Since the great deal of software packs that exist nowadays to the applications of the system of information and also the difficulty that a client has to choose the pack that supplies the necessities, we present a work about the procedure to choose a software pack in the Information System Area. In this procedure we use the rule NBR 12119 from the ABNT (Brazilian Association of Technical Rules) and the QFT (Quality Function Deployment). Two case studies about the procedure to choose a software pack are presented in this work as well. 


\section{CAPÍTULO 1 - INTRODUÇÃO}

\section{1 - Motivação}

Com a introdução cada vez maior do computador na rotina diária das pessoas, estão surgindo diferentes pacotes de software na área de Sistemas de Informação, os quais procuram atender as diversas necessidades dos clientes. Pacote de software envolve um conjunto completo $\theta$ documentado de programas fornecidos a diversos usuários para uma aplicação ou função genérica, ou seja, trata de todos os componentes do produto disponiveis aos usuánios, tais como documentação, manual de instruçōes e guia para instalação [NBR $12119,1996]$. Existem pacotes para Sistemas de Informação que são destinados à realização de atividades administrativas, comerciais e financeiras das organizações nos diversos ramos de atividades. Por exemplo, pacotes para folha de pagamento, controle de estoque, vendas, contabilidade, faturamento, controle fiscal, sistemas especificos para escolas, bancos, saúde, jurídico e comércio.

Diante de muitas opçס̄es de pacote de software para a mesma aplicação, o cliente defronta-se com um dilema: Qual escolher? A reação natural é que a escolha seja feita por aquele pacote que atenda melhor suas necessidades. 
A totalidade dos aspectos e características de um produto de software que the confere a capacidade de satisfazer as necessidades explícitas e implícitas do cliente é definida pela ISO (Intemational Standardization Organization) ISO/IEC 9126 (1991) como qualidade do produto de software.

Outro autor também relaciona necessidades do cliente à qualidade do produto. Pressman (1994) define qualidade de software como "a conformidade aos requisitos de desempenho e de funcionalidade que foram explicitamente definidos, aos padrões de desenvolvimento explicitamente documentados, e às características implícitas que são esperadas por todo software desenvolvido por profissionais".

Dois problemas porem interferem na escolha do pacote de software: o primeiro problema que surge é saber que características do pacote de software devem ser observadas para que se compreenda melhor sua potencialidade e sua adequação às reais necessidades do cliente. Para solucionar esse problema, neste trabalho considera-se a norma NBR 12119 Tecnologia de Informação - Pacotes de software - Teste e requisitos de qualidade, elaborada pela ABNT (Associação Brasileira de Normas Técnicas) - Fórum Nacional de Normalização. Nessa norma são estabelecidos os requisitos de qualidade para pacotes de software e instruções de como um produto deve ser testado em relação a esses requisitos. Os requisitos de qualidade de pacote de software envolvem a descrição do produto, o manual do usuánio e os programas e dados, caso existam.

O segundo problema que interfere na escolha relaciona-se a como traduzir as necessidades do cliente em requisitos de pacote de software. Essa tradução não é uma tarefa trivial, o processo de conversão é complicado e problemático.

O processo de seleção de pacotes de software começa com as necessidades do cliente, que em geral são características qualitativas definidas sem muita rigidez, tais como "ser bom", "ser fácil de usar", "ser fácil de aprender a usar", "funcionar bem", etc. Essas características são importantes para o cliente, porém não são quantificáveis, e, portanto, de difícil operacionalização. Elas devem ser convertidas em requisitos de produto, por exemplo, "fácil de aprender" pode ser convertida em "tempo para completar o tutorial", "número de icones" e "número de facilidades de help on-line". Os requisitos de produto costumam ser características globais do software (geralmente mensuráveis), que iräo satisfazer às necessidades do cliente se apropriadamente executadas [Eureka, 1992].

O problema de conversão das necessidades e desejos dos clientes em requisitos de pacote de software, na verdade, é o mesmo (ou está relacionado àquele) encontrado nos setores de manufatura e serviço. Assim, neste trabalho, para solucionar o problema de 
"tradução" dos requisitos será utilizada uma abordagem do programa de Gerenciamento da Qualidade Total (TQM - Total Quality Management) (Figura 1.1), originalmente utilizada em ambientes de manufatura tradicionais que pode ser de grande valia para introduzir qualidade no processo de seleção de pacote de software.

A abordagem do programa de Gerenciamento da Qualidade Total que pode ser usada para orientar a tradução das necessidades do cliente em requisitos de qualidade de pacote de software denomina-se QFD (Quality Function Deployment).

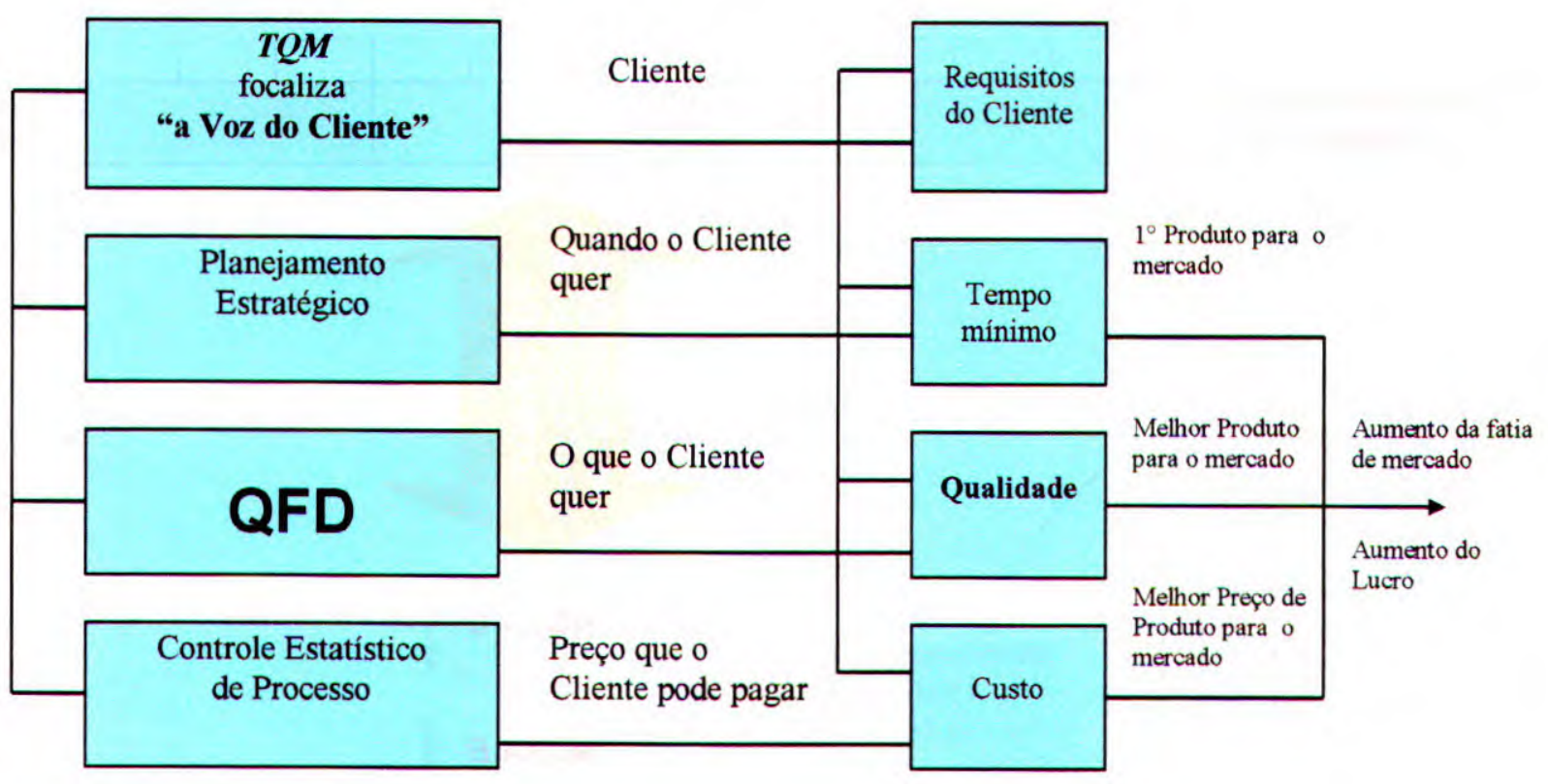

Figura 1.1 - Overview do TQM [Haag, 1996]

O QFD é mais originalmente direcionado para desenvolvimento de software, mas neste trabalho ele será adaptado para seleção de pacote de software.

\section{2 - Objetivo}

Diante das inúmeras opções de pacotes de software que existem atualmente para as aplicações de Sistemas de Informação e da dificuldade que um cliente tem para escolher aquele pacote que atenda melhor suas necessidades, neste trabalho é apresentado um procedimento para escolha de pacote de software na área de Sistemas de Informação (Figura 1.2). Nesse procedimento são utilizadas a norma NBR 12119 da Associação Brasileira de Normas Técnicas (ABNT) e o QFD do American Supplier Institute (ASI). 


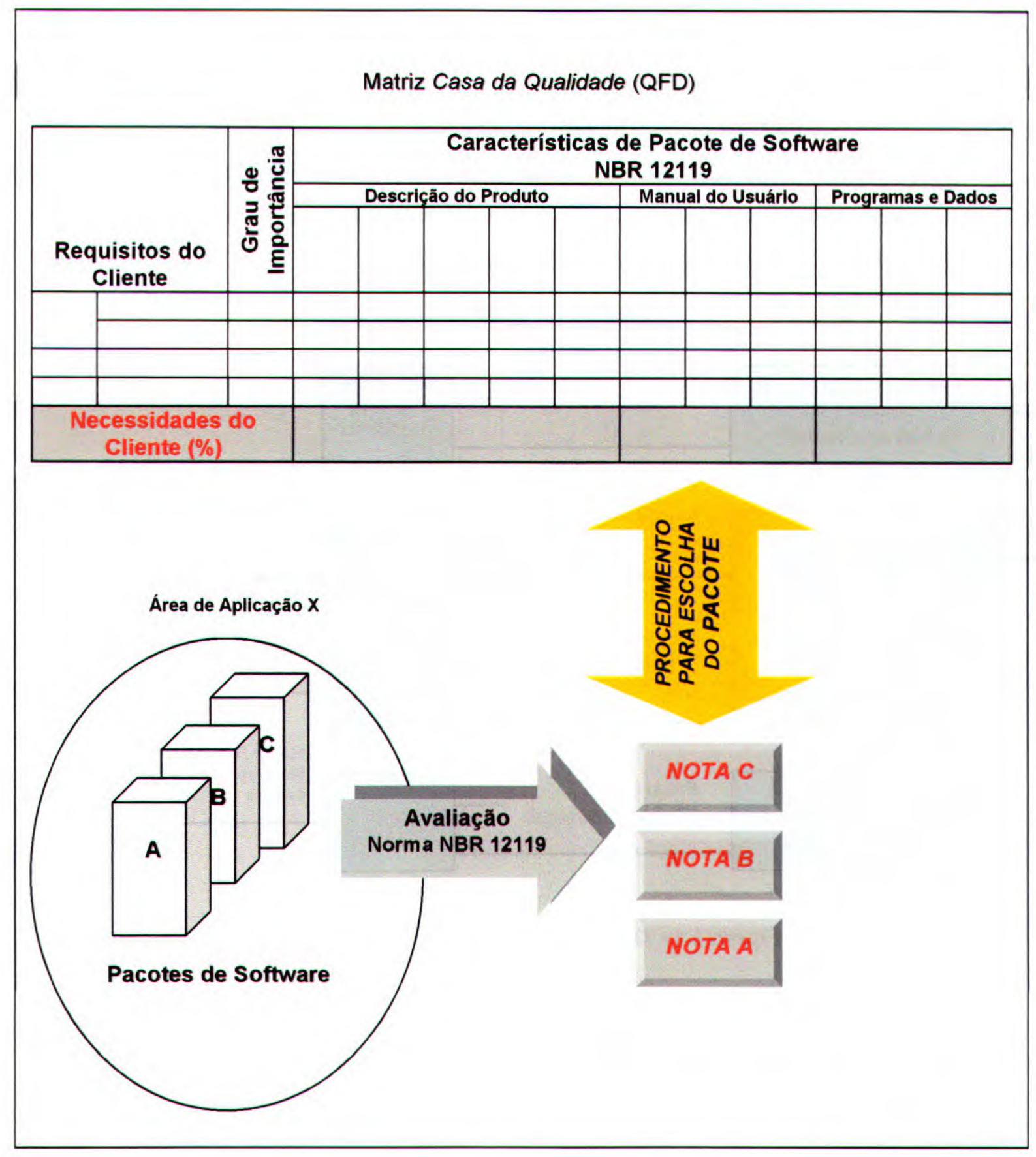

Figura 1.2 - Procedimento para Escolha de Pacote de Software 


\section{3 - Organização do Trabalho}

Este trabalho está organizado em oito capitulos. Neste capitulo, descreve-se a motivação e o objetivo do trabalho.

No Capitulo 2 é apresentado uma visão geral do QFD "tradicional". Apresenta-se as matrizes do QFD na versão do American Supplier Institute (ASI), dando ênfase a matriz Casa da Qualidade, por ser essa a de maior utilidade no desenvolvimento do trabalho.

No Capítulo 3 estão descritos o modelo de avaliação da qualidade de produto e de pacote de software (norma ISO/IEC 9126 e norma NBR 12119).

Para obter as necessidades do cliente é necessánio um planejamento. Neste trabalho, esse planejamento envolve um processo denominado processo de aquisição de conhecimento IPAIA, instanciado para o domínio QFD - Casa da Qualidade. No Capítulo 4 está descrito o processo de aquisição de conhecimento genérico, o qual pode ser utilizado em qualquer domínio de conhecimento. No Capítulo 5 são apresentados o processo de aquisição de conhecimento IPAIA, instanciado para o domínio QFD - Casa da Qualidade e a estratégia para elaboração da matriz Casa da Qualidade.

No Capitulo 6 está descrito um procedimento para escolha de pacote de software na área de Sistemas de Informação que é usado para avaliar pacote de software.

Dois estudos de caso são descritos no Capítulo 7 e mostram exemplos da utilização do procedimento para escolha de pacote de software na área de Sistemas de Informação.

Finalmente, o Capítulo 8 mostra as conclusões, bem como propostas para futuras pesquisas que podem ser desenvolvidas.

No Apêndice A é apresentada a ferramenta QFDT (Quality Function Deployment Tool) utilizada para elaborar as matrizes Casa da Qualidade obtidas nos dois estudos de caso descritos no Capítulo 7. 


\section{CAPÍTULO 2 - A VISÃO DO AMERICAN SUPPLIER INSTITUTE (ASI) DO QFD}

\section{1 - Considerações Iniciais}

O desdobramento da função qualidade (QFD) é uma forma sistemática de assegurar que o desenvolvimento de atributos, características e especificaçōes do produto, assim como a seleção e o desenvolvimento de equipamentos, métodos e controle do processo sejam dirigidos para as demandas do cliente ou do mercado.

Dentre as várias versões do QFD, a versão do American Supplier Institute (ASI) é a mais adequada para aplicaçōes de software, e utiliza apenas a Casa da Qualidade.

Nos tópicos a seguir, serão abordados o QFD "tradicional", as matrizes do QFD e em especial a matriz Casa da Qualidade.

\section{2 - Desdobramento da Função Qualidade "Tradicional" (QFD- Tradicional)}

O Desdobramento da Função Qualidade (QFD - Quality Function Deployment) é uma metodologia que converte a voz do cliente em projetos de produto e serviço, ou seja, traduz as necessidades do cliente em requisitos apropriados à empresa, em cada estágio do 
processo de desenvolvimento do produto, desde a pesquisa e o desenvolvimento até a engenharia, a produção, o marketing, as vendas e a distribuição [Eureka, 1992], [Becker, 1998].

O método QFD foi originalmente proposto por Yoji Akao, em 1966, professor de Engenharia Industrial da Universidade Tamagawa em Tokyo e um dos primeiros líderes do movimento Total Quality Control (TQC) no Japäo [Akao, 1990]. O propósito foi desenvolver um método de garantia de qualidade que projetaria a satisfação do cliente em produto antes que ele fosse manufaturado. Os métodos anteriores de controle de qualidade tinham como objetivo resolver um problema durante ou após a manufatura [Mazur, 1998]. A proposta de Akao permitia que todos os empregados da empresa participassem do projeto de novos produtos. A idéia básica é converter os requisitos do cliente em requisitos técnicos apropriados para cada estágio do processo de manufatura. Portanto, a voz do cliente é a entrada básica exigida para iniciar um projeto QFD.

O QFD foi implementado nos estaleiros KOBE da Mitsubishi Heavy Industries em 1972, com a ajuda dos Drs. Shigeru Mizuno e Furukawa, que desenvolveram uma matriz contendo as exigências do cliente $e$ as caracteristicas da qualidade.

$\mathrm{Na}$ década de 70, esse método se difundiu no Japão, destacando-se as aplicaçōes na montadora de veículos Toyota Auto Body e em seus fornecedores [Hauser, 1988]. Só na década de 80 as empresas americanas começaram a implementar O QFD. Hoje estima-se que essa metodologia tenha sido adotada por mais de cem empresas americanas [Carvalho, 1997].

No Japão, o QFD é utilizado principalmente na indústria automotiva, também sendo utilizado em eletrônica, indústrias de eletrodomésticos, confecçōes, circuitos integrados e máquinas agrícolas. Além disso, escolas de natação e empresas de decoração de ambientes também têm adotado essa técnica [Hauser, 1988]. Nos Estados Unidos, O QFD tem sido utilizado na indústria automotiva, mas a indústria de computadores também têm demonstrado grande interesse nessa abordagem [King, 1987].

Segundo Akao (1990), QFD é a conversăo dos requisitos do consumidor em caracteristicas de qualidade do produto e o desenvolvimento da qualidade de projeto para 0 produto acabado através de desdobramentos sistemáticos das relações entre os requisitos do consumidor $\theta$ as características do produto. Esses desdobramentos iniciam-se com cada mecanismo e se estendem para cada componente ou processo. A qualidade global do produto será formada através dessa rede de relações. 
O processo QFD envolve a construção de uma ou mais matrizes (algumas vezes chamada "tabelas de qualidade"). A estrutura hierárquica das matrizes auxilia a obter informações detalhadas e precisas a partir de requisitos vagos e abstratos dos clientes. As matrizes quebram as barreiras funcionais, encorajando o trabalho em equipe.

O QFD foi criado para auxiliar o processo de gestão de desenvolvimento do produto denominada ação gerencial do planejamento da qualidade. Essa ação pode ser, de forma bem simples, sequenciada em quatro etapas a seguir [Cheng, 1995]:

1. Finalidade do produto (a que necessidades e desejos o produto deve satisfazer);

2. Identificação das características do produto (que caracteristicas, materiais e tecnologias são necessários);

3. Identificação dos processos (qual é o fluxograma de processo e como aquelas características podem ser agregadas;

4. Plano experimental de fabricação (se der certo é adotado como padrão).

O QFD é um método eficaz para desenvolver e aperfeiçoar produtos. Sua aplicação vem crescendo em todo o mundo, possibilitando às empresas [Cheng, 1995]:

- traduzir de forma eficaz as necessidades e expectativas dos clientes;

- reduzir as reclamações de clientes;

- reduzir o desperdício de tempo e recursos financeiros no aperfeiçoamento e desenvolvimento de produtos;

- integrar a capacidade criativa de todas as pessoas envolvidas no desenvolvimento de produtos;

- melhorar a comunicação entre departamentos funcionais;

- proporcionar o crescimento e o desenvolvimento de pessoas através do aprendizado mútuo.

Especificamente, o QFD, identificado como um veículo para a implementação do Gerenciamento da Qualidade Total (TQM - Total Quality Management), tem sido proposto como uma abordagem efetiva na implementação de programas de melhoria da qualidade em uma variedade de ambientes de produtos e serviços. Procurando garantir produtos de alta qualidade, o método QFD pode ser aplicado tanto a produto (entendido como bens ou serviços) da empresa quanto a produto intermediário entre cliente e fornecedor interno. Pode ser aplicado também para remodelagem ou melhoria de produtos existentes e para produtos 
novos às empresas. A implantação do método QFD objetiva duas finalidades especificas (Figura 2.1):

- auxiliar o processo de desenvolvimento do produto, buscando, traduzindo e transmitindo as necessidades e desejos do cliente (QD - Desdobramento da Qualidade); e,

- garantir qualidade durante o processo de desenvolvimento do produto (QFDr Desdobramento da Função Qualidade no sentido restrito).

É extenso o número de publicaçōes sobre o QFD, a maioria estudos de caso. $O$ número de versões existentes também é grande; dentre as mais difundidas estão as advogadas por Akao [Akao, 1990] e pelas organizações americanas GOAL/QPC [King, 1989] e ASI (American Supplier Institute) [ASI, 1995].

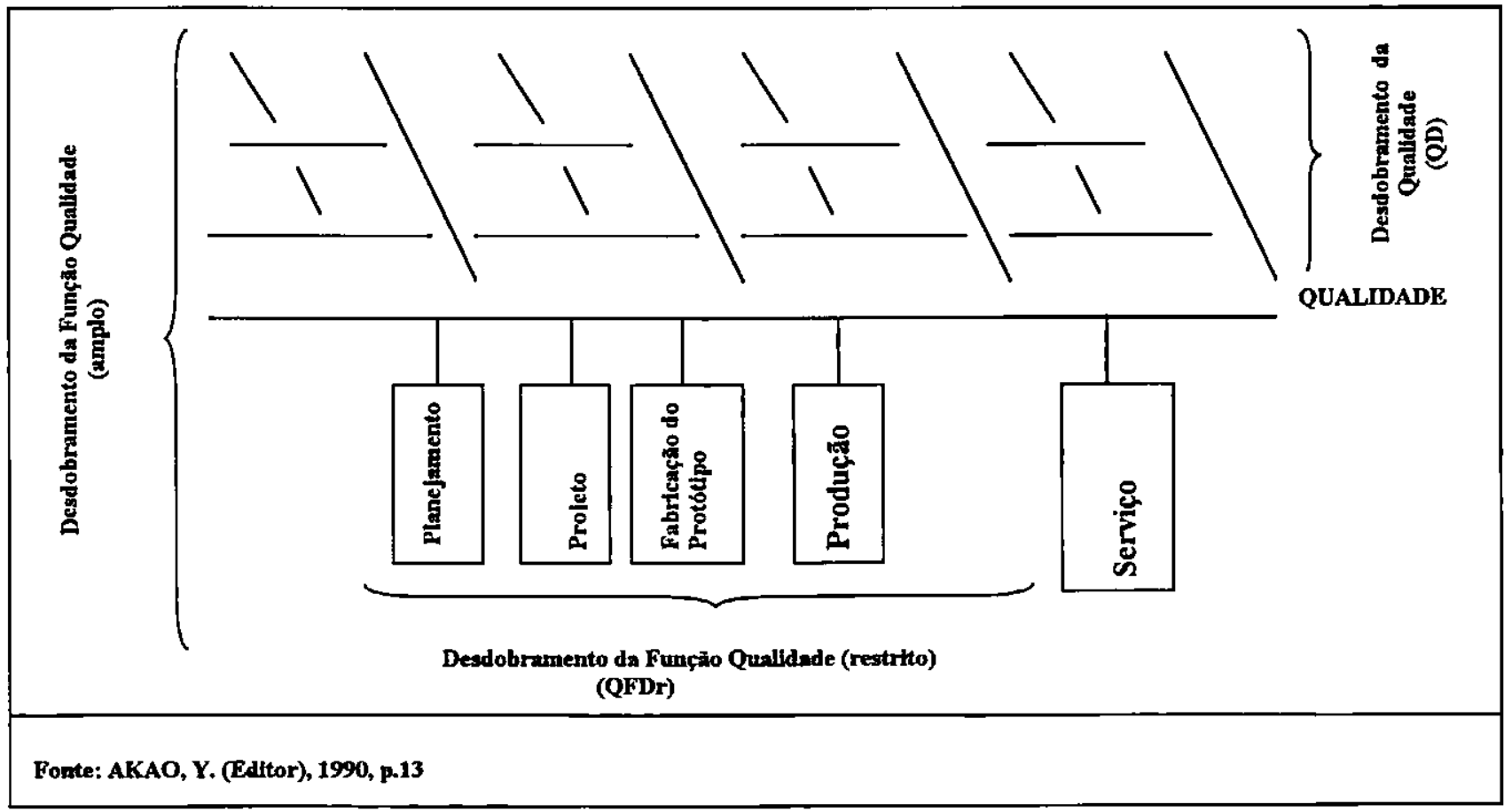

Figura 2.1 - Relação entre QFD, QD e QFDr

\section{3 - As Matrizes do QFD (ASI)}

O modelo QFD difundido pelo ASI (American Supplier Institute) é o mais simples e popular, restringindo-se ao processo de Desdobramento da Qualidade (QD). O processo de 
Desdobramento da Qualidade visa buscar, traduzir e transmitir as exigências dos clientes em características do produto, iniciando-se com a determinação da voz do cliente, passando pelo estabelecimento de funções, mecanismos, componentes, processos, matéria-prima e estendendo-se até o estabelecimento dos valores dos parâmetros de controle dos processos.

O processo de desdobramento da qualidade é alcançado através de quatro matrizes: Planejamento do Produto, Desdobramento das Partes, Planejamento do Processo e Planejamento da Produção que traduzem as necessidades do cliente apropriadamente em requisitos de produto, características das partes, operações de fabricação e requisitos de produção (Figura 2.2).

O relacionamento entre as quatro matrizes se dá através da permanência de um vetor de variáveis para a matriz subseqüente. Por exemplo, da primeira matriz permanecem os requisitos de produto selecionados que serão expandidos na matriz subseqüente em características das partes, da segunda matriz permanecem as características das partes selecionadas que serão expandidas na matriz subseqüente em operações de fabricação, e assim sucessivamente.

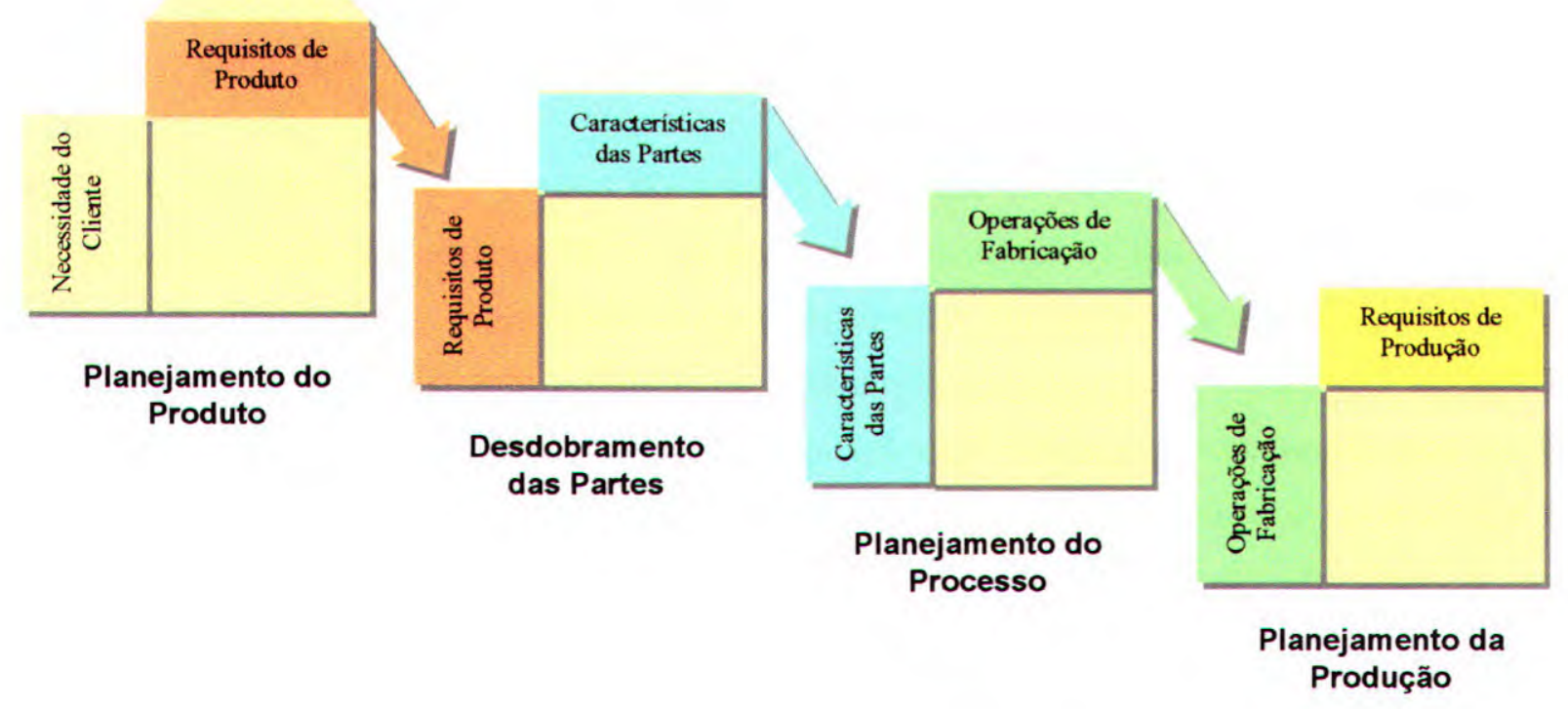

Figura 2.2 - Modelo do ASI [ASI, 1995] 
A matriz inicial é a matriz de Planejamento do Produto, também conhecida como a Casa da Qualidade (House of Quality) onde as necessidades do cliente são expandidas em requisitos de produto (Figura 2.3). Os Requisitos do Cliente pertencem ao mundo dos clientes e é importante que o processo de desenvolvimento de software, que se posiciona no lado oposto, se esforce para atender as exigências, entrando no mundo dos clientes. É nessa atitude que reside a verdadeira busca orientada à qualidade de software. Os Requisitos de Produto expressam o mundo da tecnologia. Pode-se, portanto, considerar que a Casa da Qualidade possui um significado mais profundo, isto é, "a conversão do mundo dos clientes para o mundo da tecnologia".

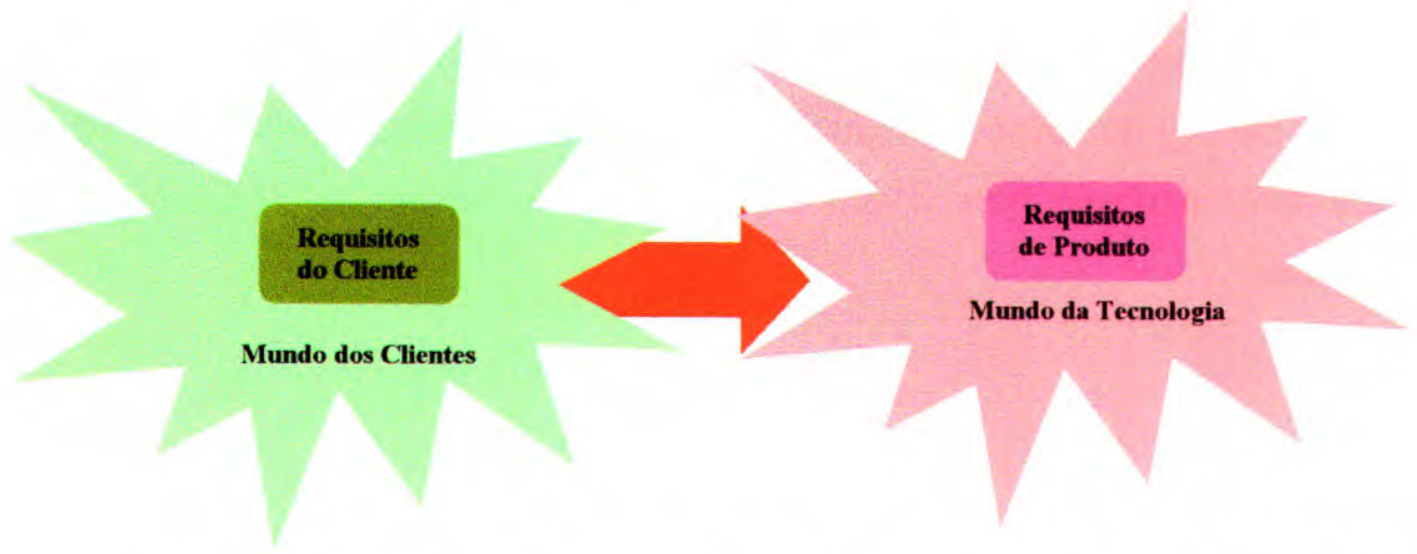

Figura 2.3 - Conversão do Mundo dos Clientes para o Mundo da Tecnologia

A matriz de Desdobramento das Partes expande alguns dos requisitos de produto, identificados na matriz Casa da Qualidade, em nível de subsistema/partes. Essa matriz serve de base para todas as atividades preliminares do produto. Nem todos os requisitos de produto da Casa da Qualidade necessitam de expansão, somente os requisitos de alto risco (novo, difícil ou extremamente importante) são expandidos [Eureka, 1992]. Essa matriz é conduzida pela engenharia do produto.

A matriz de Planejamento do Processo representa a transição do produto para o planejamento do processo. Durante o planejamento do processo, os processos de manufatura são representados através de um diagrama para cada característica crítica das partes, e os parâmetros do processo ou objetivos são documentados. Essa matriz é conduzida pela engenharia de manufatura.

Na matriz de Planejamento da Produção são criados indicadores de desempenho para monitorar o processo de produção, manter tabelas e realizar práticas de treinamento para 
operadores. Também nessa matriz final são tomadas decisões como o risco envolvido em um processo não controlado. Essa matriz é usualmente conduzida pelo departamento de garantia da qualidade em acordo com a manufatura.

O QFD na versão do ASI está baseado em paradigmas de projeto e manufatura de objetos físicos. Os paradigmas de projeto e desenvolvimento de software são diferentes, e, por isso, os engenheiros de software não usam o modelo do ASI além da Casa da Qualidade. De fato, a maiona das aplicações QFD para hardware, software e serviços usam somente a Casa da Qualidade.

Nota-se que na matriz Casa da Qualidade (Figura 2.2) existe uma diferença significativa em relação às demais matrizes que é o "telhado" da Casa da Qualidade, onde estão representadas as correlações entre os requisitos de produto.

Para este trabalho, a matriz Casa da Qualidade é considerada a mais importante, uma vez que ela é usada para detectar as necessidades do cliente e transformar essas necessidades em requisitos de produto.

\section{4 - A Matriz Casa da Qualidade}

A matriz Casa da Qualidade (Figura 2.4) é dividida em nove partes e tem como objetivo estabelecer os Requisitos do Cliente, priorizando aqueles que maximizam sua satisfação e relacioná-los a Requisitos de Produto que os traduzam. É na Casa da Qualidade que se estabelecem as metas para os Requisitos de Produto e as estratégias de desdobramento que nortearão as demais matrizes do método QFD [Carvalho, 1997].

Na matriz Casa da Qualidade se equacionam as seguintes questões:

- Como interpretar as necessidades dos clientes expressas em linguagem natural?

- Como selecionar aquelas que maximizam a satisfação do cliente?

- Como priorizar alguns requisitos do cliente conciliando os diferentes critérios?

- Em quais requisitos de produto devem ser concentrados os esforços de engenharia e os recursos disponíveis para o desenvolvimento?

- Segundo a visão do cliente, seu produto é melhor ou pior que o produto dos concorrentes?

- Como estabelecer metas quantitativas para os requisitos de produto? 


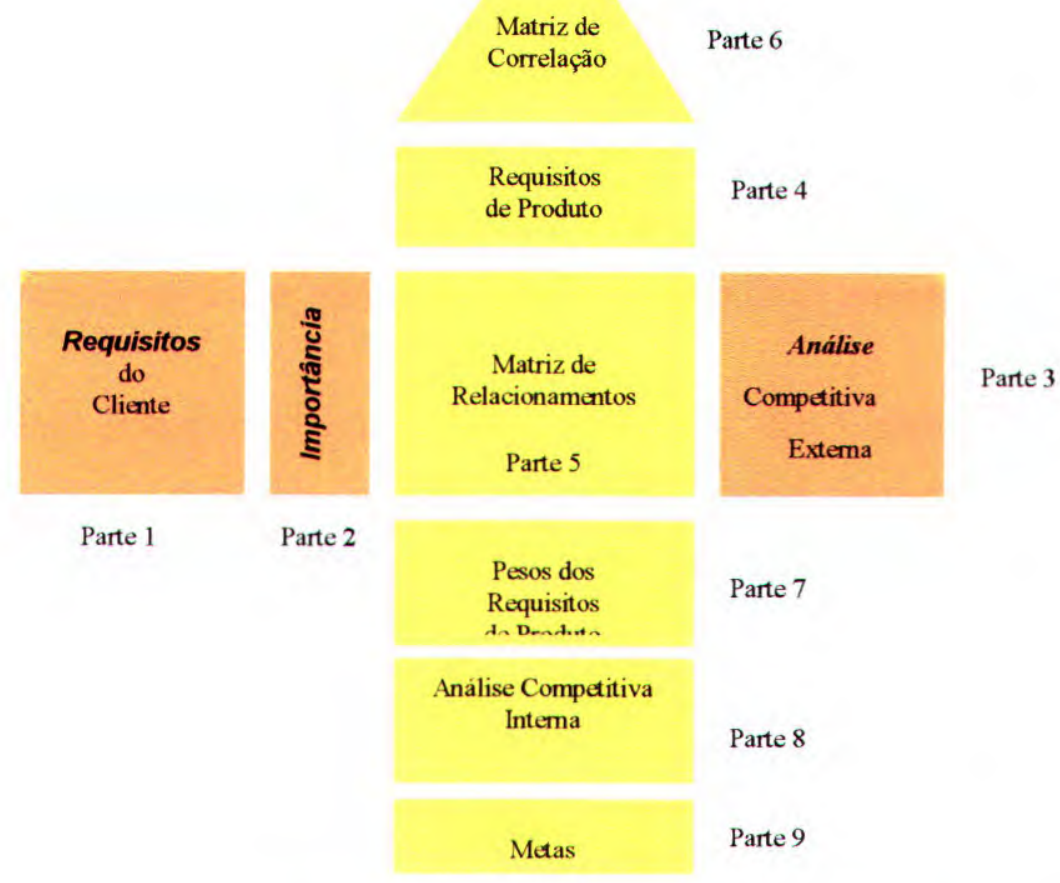

Figura 2.4 - Casa da Qualidade [Carvalho, 1997]

A seguir segue o detalhamento das nove partes da matriz Casa da Qualidade:

\section{Parte 1 - Requisitos do Cliente - A Voz do Cliente (Voice of the Customer)}

O propósito da parte 1 da Casa da Qualidade é determinar qual segmento de mercado será analisado, identificar quem serão os clientes e coletar as informações dos clientes referentes aos requisitos do produto ou serviço. Tem como objetivo captar a "voz do cliente" (voice of the customer), ou seja, os atributos que influenciam a percepção do cliente para a qualidade do produto e os pontos fortes e fracos do mesmo com relação a esses atributos, sempre do ponto de vista do cliente.

O propósito da voz do cliente é conhecer as expectativas, os desejos declarados e os desejos implícitos do cliente. Desse modo, obter a voz do cliente é o ponto principal do processo QFD, uma vez que os demais estágios do método irão traduzir as informações obtidas do cliente, expressas em linguagem natural, para a linguagem técnica. Se uma representação incorreta dos desejos do cliente for obtida, o processo QFD levará à frente o 
produto indevido. Assim, obter a voz do cliente corretamente é crucial à aplicaçäo precisa do QFD [Dean, 1994a].

Para auxiliar essa parte existem ferramentas de apoio, por exemplo, diagramas de afinidades, diagramas em árvores, tabelas e matrizes.

Para satisfazer os clientes, deve-se entender como reunir os requisitos do mesmo a fim de realizar satisfação. Existe uma relação entre a avaliação subjetiva do produto expressa pelo nivel de satisfação do cliente ${ }^{1}$ e a avaliação objetiva - expressa pelo nível de desempenho do produto ${ }^{2}$, que são interessantes introduzi-los sob o ponto de vista do cliente, para saber se se trata de algo atrativo ou não para o mesmo. O diagrama de Kano (Figura 2.5) mostra as diversas visões de qualidade do produto conforme percebido pelos clientes, como as de qualidade linear, as de qualidade óbvia, compulsória ou obrigatória e as de qualidade atrativa.

As visöes de qualidade linear são os elementos de qualidade que trazem maior satisfação aos clientes à medida quẹ aumentą o nivel de desempenho do produto.

As visöes de qualidade óbvia, compulsória ou obrigatória são os elementos ide qualidade considerados óbvios, quando ò desempenho è súficiente,porém sua ausência ou insuficiência provoca insatisfação.

As visōes de qualidääde atrativa são os elęmentos de qualidade que, mesmo com desempenho insuficiente, são aceitos com resignàçãa pelos clientes, do tipo "não tem jeito". Porém, a suficiência ou presença traz grande satisfação.

O Quadro 2.1 mostra um exemplo das três visōes de qualidade sobre o serviço de transportes aéreos.

Quadro 2.1 - Exemplos de visöes de qualidade [Cheng, 1995]

\begin{tabular}{|c|l|}
\hline Visão de Qualidade & Elemento \\
\hline Llnear & $\begin{array}{l}\text { Bom atendimento } \\
\text { Pontualidade de vôo } \\
\text { Ter sIstema de desconto }\end{array}$ \\
\hline Óbvia & $\begin{array}{l}\text { Bom atendimento dos comissános } \\
\text { Poltrona confortável } \\
\text { Excelente serviço de emergência }\end{array}$ \\
\hline Atrativa & $\begin{array}{l}\text { Serviço de boas bebidas alcoólicas } \\
\text { Possibilldade de assistir televisão } \\
\text { Possibilidade de usar o telefone }\end{array}$ \\
\hline
\end{tabular}

\footnotetext{
${ }^{1}$ Escala variando de insatisfeito a satisfeito

${ }^{2}$ Escala variando de insuficiente a suficiente
} 
O modelo de Kano é dinâmico, uma vez que, a avaliação em relação as visões de qualidade apresenta um fenômeno de obsolescência, passando de:

QUALIDADE ATRATIVA

Desse modo, as características do produto que são atrativas para o cliente hoje, passam a ser óbvias amanhã. Conseqüentemente, é preciso estar sempre criando qualidades atrativas para manter as preferências dos clientes.

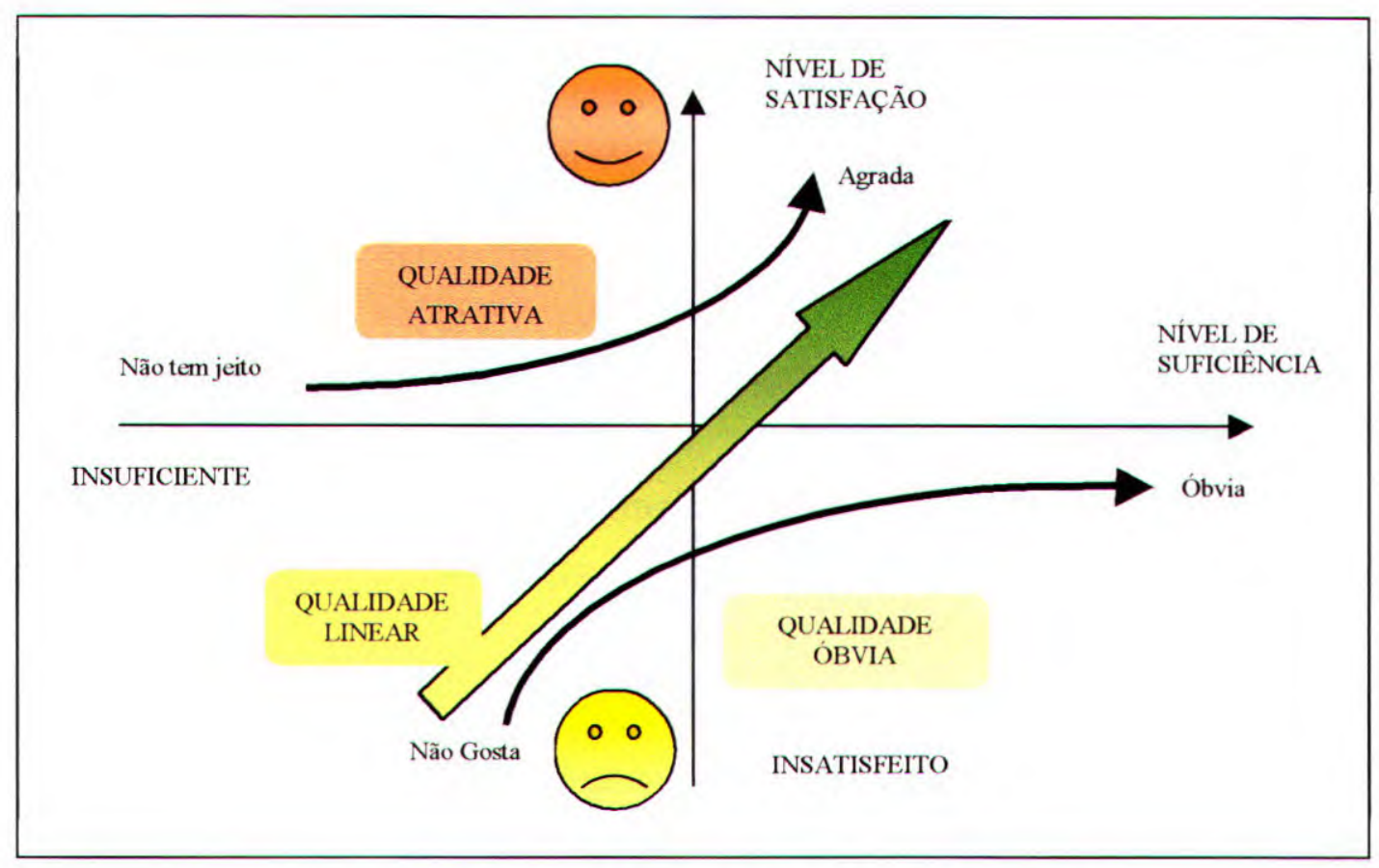

Figura 2.5 - Diagrama de Kano [Kano, 1984]

\section{CONVERSÃO DA VOZ DO CLIENTE EM REQUISITOS DO CLIENTE}

A informação obtida dos clientes por meio de pesquisas produz uma grande quantidade da informação que denomina-se dados originais. Em geral, os clientes não expressam suas necessidades diretamente, mas por meio de descrições sobre seus desejos. Esses dados precisam ser trabalhados para se transformar em informação útil para o desenvolvimento do produto.

O objetivo ao realizar as pesquisas é descobrir as verdadeiras necessidades dos clientes, portanto, é preciso converter os dados originais em necessidades. No início do 
desenvolvimento de um produto é importante pensar em todas as possiveis necessidades dos clientes. A técnica de desdobramento de cenas pode ser útil no processo de geração de idéias: a equipe visualiza cenas plausíveis de uso do produto (modificando "quem", "quando", "onde" e "como") e, a partir de uma necessidade expressa vagamente pelo cliente, obtém-se uma grande quantidade de necessidades concretas. As necessidades se referem a qualidade intrínseca do produto, preço, serviços associados ao produto, etc. Esse processo é ilustrado na Figura 2.6. Nessa etapa, é interessante identificar e organizar as necessidades que se referem à qualidade intrínseca do produto, que na literatura de QFD são denominadas qualidade exigida ou requisitos do cliente [Cheng, 1995].

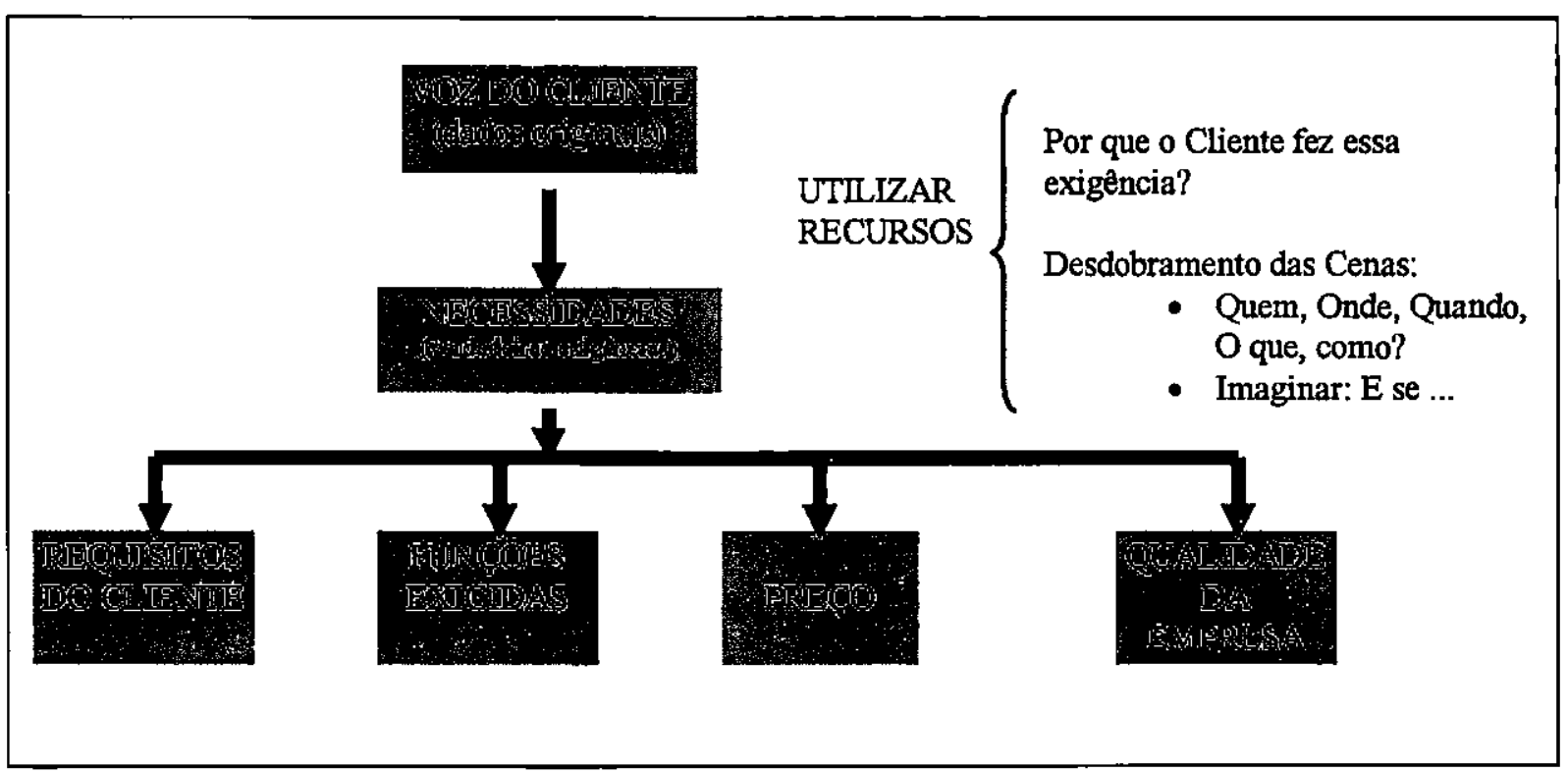

Figura 2.6 - Conversão da Voz do Cllente em Requisitos do Cliente [Cheng, 1995]

Uma vez obtidos os requisitos do cliente, esses são agrupados e hierarquizados através da tabela de desdobramento dos requisitos do cliente. Essa tabela é a representação das verdadeiras exigências dos clientes, o mais próximo possível de sua própria linguagem. Essas exigências, obtidas das várias fontes de informação, são resumidas em forma sistemática, desdobradas do nivel abstrato para o concreto, do resumido para o detalhado, utilizando o procedimento descrito no Quadro 2.2. 
Quadro 2.2 - Procedimento para elaboração da tabela de desdobramento dos requisitos do cliente [Cheng, 1995]

\begin{tabular}{|c|}
\hline $\begin{array}{l}\text { Converter as informaçöes originais (palavras dos clientes ou dados originais) em necessidades do } \\
\text { liente, usando expressöes simples e com apenas um significado. Utilizar o Desdobramento de } \\
\text { Cenas para extrair e ampliar as verdadeiras exigências dos clientes. }\end{array}$ \\
\hline $\begin{array}{l}\text { Utilizar o diagrama de afinidades para agrupar os itens similares dos requisitos do cliente (4 a } 5 \\
\text { tens por grupo) e escrever uma expressão (título) que descreva o conteúdo de cada grupo formado. }\end{array}$ \\
\hline $\begin{array}{l}\text { 3. Considerar esses títulos como itens de nívei secundário, aproximadamente. Agrupar esses itens } \\
\text { em conjuntos similares para formar itens primários, mediante a utilização do diagrama de afinidade. } \\
\text { Colocar um título para cada conjunto formado. }\end{array}$ \\
\hline $\begin{array}{l}\text { 4. Esciarecer quais são os itens primários de qualidade e acrescentar, se necessário, itens de nível } \\
\text { secundário e terciário. }\end{array}$ \\
\hline $\begin{array}{l}\text { 5. Colocar a numeração de classificação e montar a Tabela de Desdobramento dos Requisitos do } \\
\text { Cliente. }\end{array}$ \\
\hline $\begin{array}{l}\text { 6. Realizar uma análise crítica da tabeia, observando se há consistência na hier } \\
\text { classificação dos itens e se a tabela está completa tanto no șentido vertical quant } \\
\text { Acrescentar os itens de qualidade óbvia. }\end{array}$ \\
\hline
\end{tabular}

Parte 2 - Grau de Importância dos Requisitos do Cliente

O propósito dessa parte é atribuir pesos (escala Likert') que represèntam a importância de cada requisito do cllente, no ponto de vista do cliente, tendo como objetivo conhecer a intensidade de sua exigência. Esse valor obtido do cliente, segundo Akao (1996), pode ser relativo ou absoluto e será usado posteriormente na matriz de relacionamentos. $A$ escala é relativa quando o cliente indica a importância de cada requisito em comparação aos demais (este requisito é mais importante do que aquele). A escala é absoluta quando o cijente analisa a influência de cada requisito em sua decisão de compra do produto, sem comparánlo aos demais.

Como métodos para encontrar o grau de importância dos requisitos do cliente, existem o cálculo do grau de importáncia através da freqüência de duplicação ocorrida no momento da conversão dos dados primitivos para requisitos do cliente $\theta$ o método Analytical Hierarchy Process (AHP). A técnica AHP sistematiza a comparação entre os requisitos, estabelecendo um meio eficaz para determinar a importância relativa destes. O AHP é descrito, de forma sucinta, em Ohfuji (1997) [Peixoto, 1998].

\footnotetext{
${ }^{3}$ A escala de Likert varia no intervalo de 1 a 5 sendo que 1 indica "discorda fortemente" e 5 "concorda fortemente".
} 


\section{Parte 3 - Análise Competitiva Externa}

A análise competitiva externa é elaborada sob a ótica do cliente e abrange dois aspectos para cada requisito do cliente: (a) a avaliação competitiva dos produtos dos principais concorrentes existentes no mercado, e (b) a qualidade planejada [Peixoto, 1998].

A Avaliação Competitiva do Cliente é uma pesquisa quantitativa que busca identificar como os clientes percebem o desempenho do produto atual da empresa, em comparação com os principais concorrentes. A utilização do produto atual da empresa se justifica pelo alto grau de conhecimento que a equipe deve ter sobre aquele produto. A equipe deve saber exatamente qual o desempenho do produto e quais são as características que determinam esse desempenho. A partir desse conhecimento e da avaliação do cliente para o produto atual da empresa, a equipe pode estabelecer uma referência de características versus satisfação do cliente, a qual servirá de base para a análise do grau de importância (valor) dos produtos concorrentes e para a projeção da qualidade do produto em desenvolvimento.

A Qualidade Planejada está subdividida em: plano, indice de melhoria, argumento de venda, peso relativo e peso absoluto.

O plano de qualidade dos requisitos é elaborado considerando o desempenho do produto em desenvolvimento para cada requisito do cliente. Segundo Akao (1996) é no plano de qualidade que a estratégia da empresa é inserida no planejamento do produto. Para Akao (1990), o plano de qualidade deve ser definido após a análise da avaliação competitiva do cliente, do argumento de vendas e da importância do requisito. Obviamente, nesse caso, o argumento de vendas deve ser determinado antes do plano de qualidade.

Para Akao (1996), o indice de melhoria é a forma de insenir na importância final dos requisitos (peso absoluto e relativo) a intenção da empresa, ou seja, o plano estratégico da empresa. Esse índice é determinado pela divisão do desempenho desejado para o produto em desenvolvimento (que corresponde ao "Plano de Qualidade") pelos valores obtidos para o desempenho efetivo do produto atual (que corresponde ao valor da "Própria Empresa"). Reflete quantas vezes o produto precisa meihorar seu desempenho, em relação ao produto atual, para alcançar a situação planejada.

Os argumentos de vendas são os benefícios-chave que o produto fornecerá aos clientes visando o atendimento de suas necessidades [Cheng, 1995] e, por isso, significam o grau de conformidade dos requisitos dos clientes com a política da empresa para o mercado alvo [Akao, 1996]. Pode-se, então, interpretar que os argumentos de vendas especiais (peso $1,5)$ são as qualidades atrativas $e$ os argumentos de vendas comuns (peso 1,2) são as 
qualidades lineares mais "valorizadas" pelos clientes, cujo desempenho planejado deverá "sobrepujar" amplamente o desempenho dos concorrentes.

O peso absoluto dos requisitos é determinado pela multiplicação do "grau de importância" pelo "índice de melhoria" e pelo "argumento de vendas". Representa a prioridade de atendimento de cada requisito sob a lógica de que os esforços de melhoria devem ser concentrados em três pontos: nos requisitos mais importantes, nos requisitos que estão em consonância com a estratégia da empresa e nos requisitos que a empresa ainda precisa melhorar bastante.

O peso relativo dos requisitos é determinado pela conversão do peso absoluto em percentagem, através da divisão do peso absoluto de cada requisito pelo resultado da soma de todos os pesos absolutos. Os pesos relativos tem por objetivo facilitar a rápida percepção da importância relativa dos requisitos.

\section{Parte 4 - Requisitos de Produto - A Voz do Engenheiro (Voice of the Engineer)}

O propósito dessa parte é traduzir a "voz do cliente" para a "voz do engenheiro", ou seja, transformar os Requisitos do Cliente em Requisitos de Produto. Para tal, lista-se os requisitos de produto que estão diretamente relacionados aos requisitos do cliente estabelecidos anteriormente. Um requisito de produto pode afetar mais de um requisito do cliente. Os requisitos de produto devem ser mensuráveis, uma vez que deverão ser controlados e comparados com os valores estabelecidos como meta [Carvalho, 1997].

Pode-se utilizar dois métodos para fazer a identificação dos requisitos de produto. $O$ primeiro é pelo método independente e o segundo é utilizando tabelas de extração [Ohfuji, 1997]. No desdobramento pelo método independente pode-se utilizar o brainstorming. Devese separar as "idéias" objetivamente mensuráveis daquelas não objetivamente mensuráveis. As mensuráveis são características de qualidade ou requisitos de produto $e$ as não mensuráveis são os elementos de qualidade. Os elementos de qualidade são definidos como itens não quantificáveis, capazes de avaliar a qualidade do produto. $\mathrm{Na}$ extração (segundo método), deve-se utilizar tabelas de extração, conforme proposto por Akao (1996) e Cheng (1995).

Extraidos os requisitos de produto, deve-se organizá-los em formato de diagrama em árvore. Para isso, deve-se utilizar a técnica do diagrama de afinidades [Akao, 1996; Akao, 1990; Cheng, 1995; Ohfuji, 1997; entre outros]. 


\section{Parte 5 - Matriz de Relacionamentos}

Na matriz de relacionamentos é estabelecido o relacionamento entre os Requisitos do Cliente e os Requisitos de Produto. Em geral, o relacionamento pode ser forte, moderado ou fraco, sendo representados pelos simbolos $x, O, \Delta$, respectivamente. Usualmente, adota-se a seguinte escala para quantificar os relacionamentos: relacionamento forte vale 9 pontos, relacionamento moderado vale 3 pontos e relacionamento fraco vale 1 ponto. Após o preenchimento dessa matriz é possivel indicar se os requisitos de produto satisfazem adequadamente aos requisitos do cliente. A ausência de símbolos ou a maioria de sinais de relacionamento fraco indica que, para um determinado requisito do cliente, não são atribuidos requisitos de produto capazes de traduzir aquela necessidade expressa pelo cliente em parâmetros de projeto [Carvalho, 1997]. Se não houver correlação entre os requisitos, o espaço em linhas ou colunas da matriz ficará vazio. Linhas ou colunas em branco indicam posições onde a conversão dos requisitos do cliente em requisitos de produto foram inadequados, o que determina verificar a consistência dessa matriz [Eureka, 1992]. Após a análise crítica dessa matriz, pode-se complementar os requisitos de produto para assegurar que todos os requisitos do cliente estão adequadamente traduzidos, ou então rever o agrupamento e a hierarquia entre os requisitos do cliente [Carvalho, 1997].

\section{Parte 6 - Matriz de Correlação Triangular}

Na matriz de correlação triangular, ou "telhado" da Casa da Qualidade, estão representadas as correlaçōes entre os requisitos de produto. A finalidade dessa matriz é explicar a dependência entre os requisitos de produto, $e$, consequentemente, identificar requisitos de produto conflitantes, para os quais é difícil a otimização conjunta quanto à satisfação do cliente, bem como aqueles que interagem de forma positiva. A correlação também é expressa por simbolos, que representam o grau de intensidade da correlação e a forma como um requisito modifica o outro (positiva ou negativa) [Carvalho, 1997]. Os símbolos usados comumente são um círculo (positiva), círculo duplo (positiva forte), cruz (negativa), cruz dupla (negativa forte). As correlações positivas ajudam a identificar os requisitos de produto que estão intimamente relacionados e evitam a duplicação de esforços pela empresa. Correlações negativas representam condições que provavelmente exigirão substituiçōes [Eureka, 1992]. 
Parte 7 - Peso dos Requisitos de Produto

A partir da matriz de relacionamentos e do peso relativo dos requisitos do cliente, é possivel estabelecer os pesos absoluto e relativo dos requisitos de produto. $O$ peso absoluto é o resultado da soma vertical dos valores anotados na parte inferior das células de cada requisito de produto (coluna). Indica a importância de cada requisito de produto no atendimento do conjunto de requisitos dos clientes. $O$ peso relativo é a transformação do peso absoluto dos requisitos de produto em percentual. Calcula-se dividindo o peso absoluto de cada requisito de produto pelo resultado da soma dos pesos absolutos de todos os requisitos de produto [Peixoto, 1998]. O peso relativo fomece uma diretriz para a seleção dos requisitos de produto a serem elaborados nas matrizes subseqüentes do QFD. Os requisitos de produto selecionados são aqueles que maximizam a satisfação do cliente e, portanto, nos quais devese concentrar os esforços de engenharia [Carvalho, 1997].

\section{Parte 8 - Análise Competitiva Interna}

A análise competitiva intema é elaborada sob a ótica da engenharia e abrange a avaliação comparativa dos produtos dos principais concorrentes existentes no mercado, para cada requisito de produto.

A análise competitiva intema, também chamada de matriz de Benchmarking Intemo, é elaborada pela equipe do QFD com o objetivo de quantificar, na unidade de medida mais adequada, os requisitos de produto sendo desenvolvido e os requisitos de produto dos principais concorrentes. É importante ressaltar que podem existir inconsistências entre a avaliação do cliente e a da equipe. Deve-se, portanto, fazer uma análise critica, revendo os relacionamentos entre requisito de produto e requisito do cliente, bem como os dados das análises competitivas intemas e extemas [Carvalho, 1997].

\section{Parte 9 - Metas Quantitativas}

As metas para cada requisito de produto são obtidas através do consenso da equipe. Tais metas devem ter valores mensuráveis que possam ser avaliados no produto final. Para chegar ao valor a ser estipulado para um determinado requisito de produto, a equipe baseiase na análise competitiva intema, bem como na matriz de correlação triangular e no peso relativo do requisito de produto. Essas metas devem ser aferidas a cada estágio do desenvolvimento do produto e do processo experimental [Carvalho, 1997]. 
Alguns autores incluem ainda a avaliação da dificuldade técnica' e do custơ estimado para atingir as metas para cada requisito de produto, feita de forma subjetiva pela equipe, utilizando pesos ou percentagens [Carvalho, 1997].

Estabelecer metas significa traçar o plano de melhoria para os requisitos de produto. Isso implica definir novos valores para esses requisitos de produto ou manter os valores atuais, com o objetivo de superar os concorrentes nos requisitos de maior importância segundo o mercado (maior peso relativo) [Cheng, 1995].

$\mathrm{Na}$ casa da qualidade as informaçōes do mundo dos clientes são convertidas em informações do mundo da tecnologia (linguagem técnica). O procedimento para elaborar a matriz Casa da Qualidade pode ser visualizado no fluxograma da Figura 2.7.

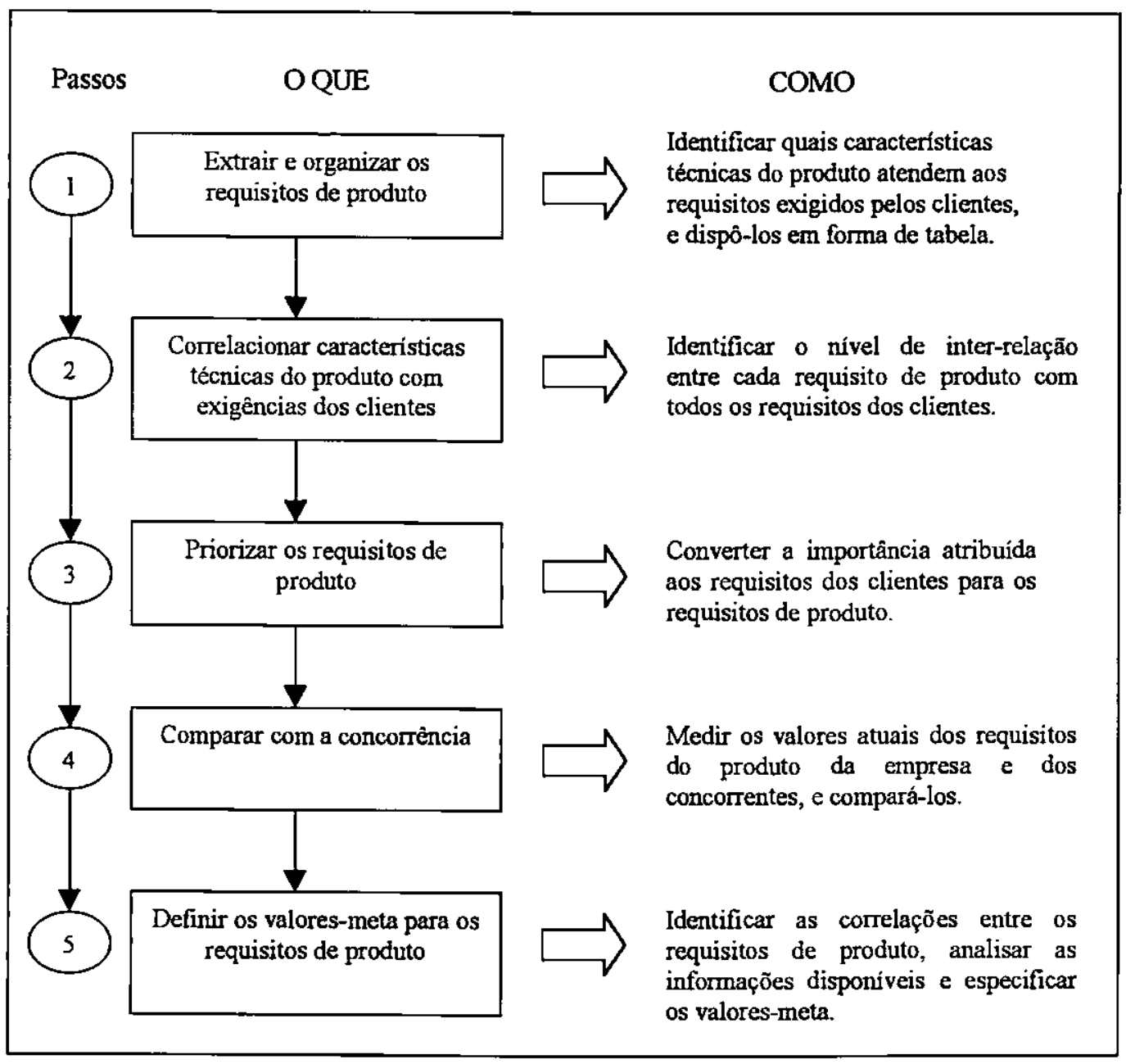

Figura 2.7 - Procedimento para traduzir a voz dos clientes em informaçōes de projeto [Cheng, 1995] 


\section{5 - Considerações Finais}

Neste capítulo foi apresentada uma visão geral do desdobramento da furıção qualidade "tradicional" e as matrizes do QFD na versão do American Supplier Institute, destacando a matriz Casa da Qualidade, por ser ela utilizada no contexto da engenharia de software.

No próximo capitulo apresenta-se duas normas relacionadas à qualidade de produto de software utilizadas na parte 4 da matriz Casa da Qualidade. 


\section{CAPÍTULO 3 - MODELOS DE AVALIAÇÃO DA QUALIDADE DE PRODUTOS DE SOFTWARE}

\section{1 - Considerações Iniciais}

Quando se fala em qualidade de software, a versão mais intuitiva é aquela de que o software produto tem qualidade quando satisfaz os requisitos que foram impostos pelos clientes [Silva, 1998]. Desse modo, a primeira versão de qualidade de software concentra o esforço em avaliar a qualidade do software produto depois de pronto, para que um produto defeituoso não chegue às mãos do cliente. Essa abordagem, dentro do contexto de qualidade de software é conhecida como qualidade de produto de software.

A qualidade de software não pode ser especificada somente como um software (produto) sem erros. A especificaçāo da qualidade de software deve ser mais exata $e$ detalhada. A formalização da qualidade de software pode ser feita usando modelos de qualidade.

Neste capítulo sāo apresentadas duas normas relacionadas à qualidade de produtos de software: a norma ISO/IEC 9126 e a norma NBR 12119. 


\section{2 - Norma ISO/IEC 9126 - Qualidade de Produtos de Software}

A norma ISO/IEC 9126 foi publicada em 1991 e é uma das mais antigas dentro do contexto de qualidade de software. Essa norma já possui sua tradução para o Brasil, publicada em agosto de 1994 como NBR 13596.

Essas normas listam o conjunto de características que devem ser verificadas em um software para que ele seja considerado um "software de qualidade". Essas características dividem-se em seis grandes grupos (Figura 3.1), cada um dividido em algumas subcaracterísticas.

A norma ISO/IEC 9126 define minuciosamente o que se pretende avaliar em cada característica e subcaracterística.

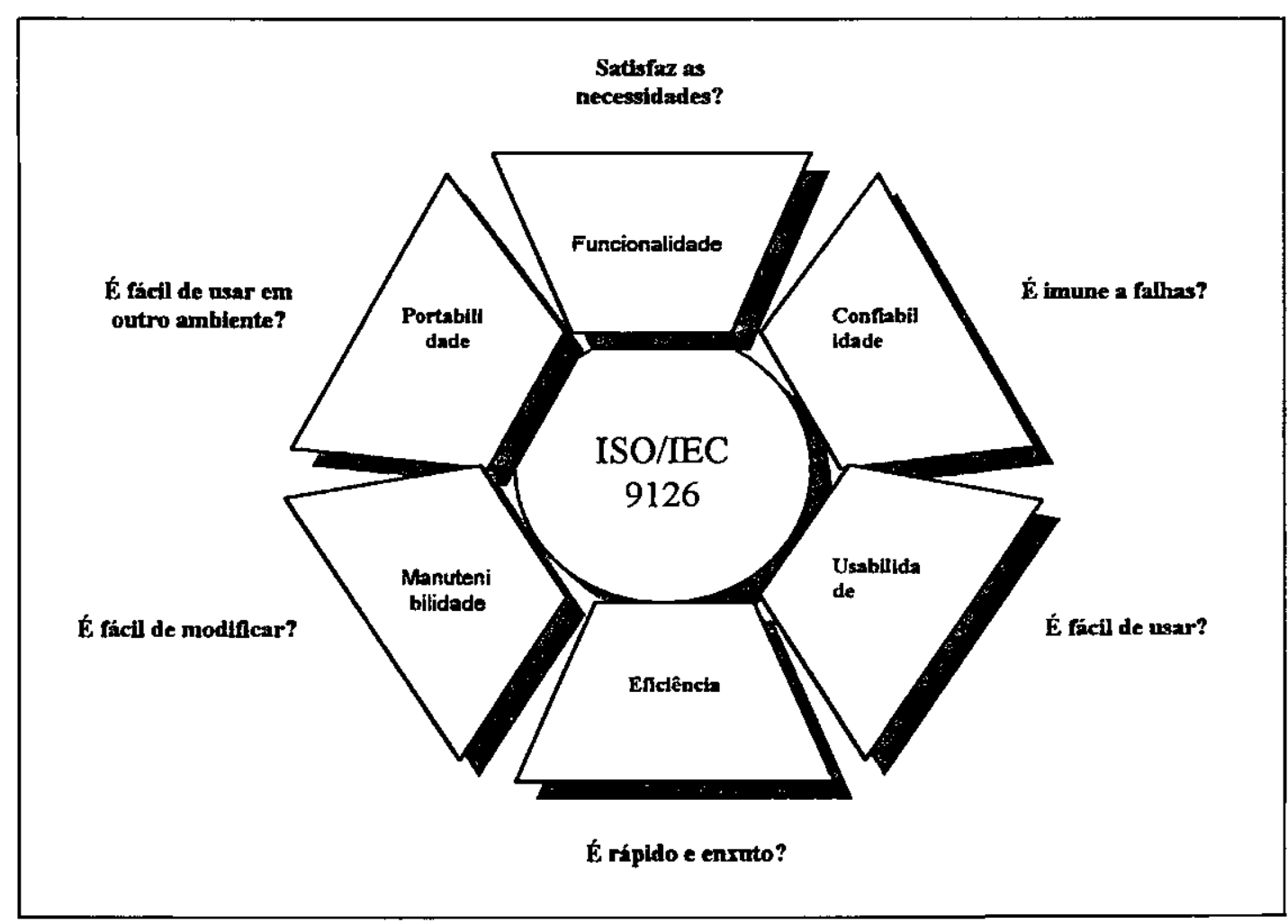

Figura 3.1 - As seis Características de Qualidade de um Software

Segue abaixo uma breve definição das seis características de qualidade do software produto e de suas respectivas subcaracterísticas [ISO/IEC 9126, 1991]: 


\section{Funcionalidade}

"Conjunto de atributos que evidenciam a existência de um conjunto de funções e suas propriedades especificadas. As funções são as que satisfazem as necessidades explicitas ou implicitas."

As subcaracteristicas para Funcionalidade apresentadas pela ISO/IEC 9126, de forma informativa são as que seguem:

Adequação: Atributos do software que evidenciam a presença de um conjunto de funções e sua apropriação para as tarefas especificadas;

Acurácia: Atributos do software que evidenciam a geração de resultados ou efeitos corretos ou conforme estabelecidos;

Interoperabilidade: Atributos do software que evidenciam sua capacidade de interagir com sistemas especificados;

Conformidade: Atributos do software que fazem com que o mesmo esteja de acordo com as normas, convençōes ou regulamentações previstas em leis e descrições similares, relacionadas a aplicação;

Segurança de Acesso: Atributos do software que evidenciam sua capacidade de evitar o acesso não autorizado, acidental ou deliberado a programas e dados.

\section{Confiabilidade}

"Conjunto de atributos que evidenciam a capacidade do software de manter seu nivel de desempenho sob condições estabelecidas durante um periodo de tempo estabelecido."

As subcaracteristicas para Confiabilidade apresentadas pela ISO/IEC 9126, de forma informativa são as que seguem:

Maturidade: Atributos do software que evidenciam a freqüência de falhas por defeitos no software; 
Tolerância a Falhas: Atributos do software que evidenciam a sua capacidade em manter um nivel de desempenho especificado nos casos de falhas no software ou de violação nas interfaces especificadas.

Recuperabilidade: Atributos do software que evidenciam sua capacidade de restabelecer seu nível de desempenho, em caso de falhas, em tempo e esforço necessário para tal.

\section{Eficiência}

"Conjunto de atributos que evidenciam o relacionamento entre o nivel de desempenho do software e a quantidade de recursos usados, sob condiçōes estabelecidas."

As subcaracterísticas para Eficiência apresentadas pela ISO/IEC 9126, de forma informativa são as que seguem:

Comportamento em Relação ao Tempo: Atributos do software que evidenciam seu tempo de resposta, tempo de processamento e velocidade de execução de suas funçōes.

Comportamento em Relação a Recursos: Atributos do software que evidenciam a quantidade de recursos usados e a duração de seu uso na execução de suas funções.

\section{Usabilidade}

"Conjunto de atributos que evidenciam o esforço necessário para se poder utilizar o software, bem como o julgamento individual desse uso, por um conjunto explicito ou implícito de usuários."

As subcaracterísticas para Usabilidade apresentadas pela ISO/IEC 9126, de forma informativa são as que seguem:

Inteligibilidade: Atributos do software que evidenciam o esforço do usuário para reconhecer o conceito lógico e sua aplicabilidade;

Apreensibilidade: Atributos do software que evidenciam o esforço do usuário para aprender a utilizar o software (por exemplo: o controle de operação, entrada, saídas); 
Operacionalidade: Atributos do software que evidenciam o esforço do usuário para sua operação e controle de sua operação.

Nota: A Usabilidade deve levar em conta os vários ambientes de usuários que o software podè afetar, que podem abranger desde a preparação para uso até a avaliação de resultados.

\section{Manutenibilidade}

"Conjunto de atributos que evidenciam o esforço necessário para fazer modificações especificadas no software."

As subcaracterísticas para Manutenibilidade apresentadas pela ISO/IEC 9126, de forma informativa são as que seguem:

Analisabilidade: Atributos do software que evidenciam o esforço necessário para diagnosticar deficiências ou causas de falhas, ou para identificar partes a serem modificadas;

Modificabilidade: Atributos do software que evidenciam o esforço necessário para modificá-lo, remover seus defeitos ou adaptá-lo a mudanças ambientais;

Estabilidade: Atributos do software que evidenciam o risco de efeitos inesperados ocasionados por modificações;

Testabilidade: Atributos do software que evidenciam o esforço necessário para validar o software modificado.

Nota: As modificações podem incluir correções, melhorias ou adaptações do software devido a mudanças no ambiente ou nos seus requisitos.

\section{Portabilidade}

“Conjunto de atributos que evidenciam a capacidade do software de ser transferido de um ambiente para outro."

As subcaracteristicas para Portabilidade apresentadas pela ISO/IEC 9126, de forma informativa são. as que seguem: 
Adaptabilidade: Atributos do software que evidenciam sua capacidade de ser adaptado a ambientes diferentes especificados, sem a necessidade de aplicações de outras ações ou meios além daqueles fornecidos para esta finalidade pelo software considerado;

Capacidade para ser Instalado: Atributos do software que evidenciam o esforço necessário para sua instalação num ambiente especificado;

Conformidade: Atributos do software que tornam aderente a padrões ou convençōes relacionadas à portabilidade;

Capacidade para Substituir: Atributos do software que evidenciam sua capacidade e esforço necessário para substituir um outro software, num ambiente estabelecido para este outro software.

\section{3 - Norma NBR 12119 - Qualidade de Pacotes de Software}

A norma NBR 12119 foi publicada em 1996 e trata da avaliação de pacotes de software, também conhecidos como "software de prateleira". São exemplos: processadores de texto, planilhas eletrônicas, bancos de dados, software gráficos, programas para funções técnicas ou cientificas e programas utilitários. Além de estabelecer os requisitos de qualidade para esse tipo de software, ela também destaca a necessidade de instruções para teste desse pacote, considerando esses requisitos.

Quando o software produto envolve um conjunto completo e documentado de programas fornecidos a diversos usuários para uma aplicação ou função genérica, ele é denominado um "pacote de software", ou seja, trata de todos os componentes do produto disponiveis aos usuários, tais como documentação, manual de instruções e guia para instalação.

O escopo da norma NBR 12119 refere-se a pacotes de software, na forma oferecida no mercado, e não aos processos de desenvolvimento e fornecimento de software. Os usuários dessa norma são fornecedores, entidades certificadoras, laboratórios de testes, entidades de credenciamento, auditores de laboratórios de teste, compradores e usuários que podem se beneficiar com produtos melhor especificados [NBR 12119, 1996].

Um pacote de software está em conformidade com essa norma se atende a todos os requisitos definidos na Figura 3.2. A conformidade de um produto em relação a esses requisitos pode ser dificil ou impossivel de se provar. Entretanto, um teste (incluindo a revisão 
da documentação) de acordo com o item é considerado suficiente para propiciar a confiança necessária para a certificação de conformidade de acordo com a ISO/IEC Guide 2. Nenhuma prova formal é necessária.

Os requisitos de qualidade para pacote de software envolvem a descrição do produto, o manual do usuário e os programas e dados, caso existam [NBR 12119, 1996].

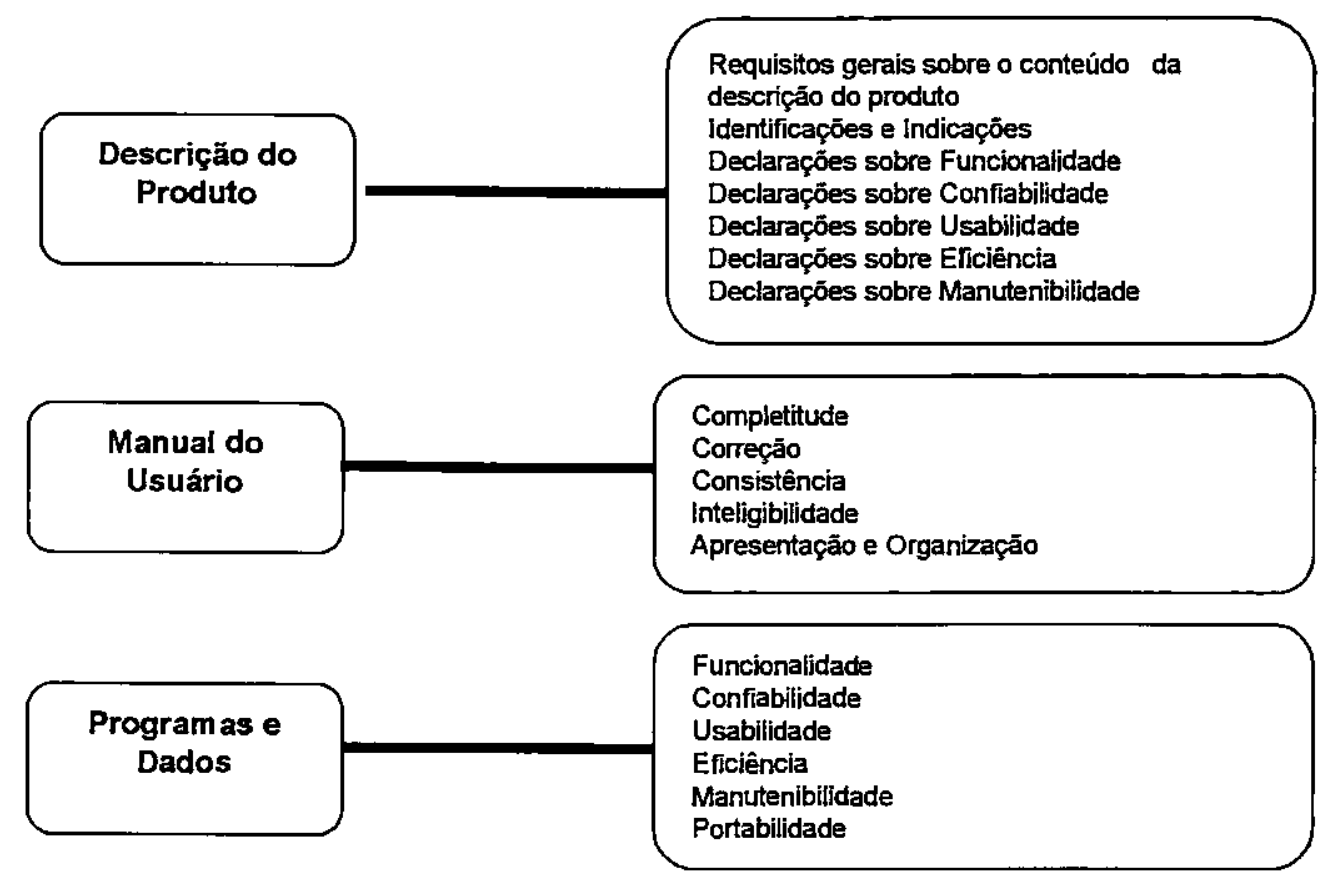

Figura 3.2 - Requisitos de Qualidade da norma [NBR 12119, 1996]

\subsubsection{Descrição do Produto}

Quando um requisito de qualidade envolve um documento expondo as propriedades de um pacote de software, com o principal objetivo de auxiliar os potenciais compradores na avaliação da adequação do produto antes de sua aquisição, ele é denominado descrição do produto.

A descrição do produto define o produto e é uma parte do conjunto de documentação do produto. Ela fornece informações sobre a documentação do usuário, programas e, se existirem, sobre os dados.

Essa descrição tem como objetivo auxiliar o usuánio ou o comprador em potencial na avaliação da adequação do produto às suas necessidades e servir como base para testes. Esse requisito inclui as principais propriedades do pacote e é um documento disponivel ao usuário, independente da aquisição do produto, contendo indicaçōes mandatónas e recomendáveis. 
Os itens para descrição do produto apresentados pela norma NBR 12119, de forma informativa, são os que seguem:

Requisitos gerais sobre o conteúdo da descriçăo: a descrição deve ser inteligivel, completa e possuir boa organização e apresentação, a fim de auxiliar os compradores em potencial na avaliação da adequação do produto às suas necessidades, antes de comprá-lo. Deve ser livre de inconsistências intemas e è interessante que cada termo tenha um unico significado.

Um documento contendo quaisquer çmbinações de recomendaçöes, requisitos ou regulamentações a serem atendidas por um pacote de software é denominado documento de requisito.

Nota: esse requisito se estende às declarações que citem documentos de requisitos, se existentes.

Identificaçōes e indicações: esse item está divido em oito subitens:

a) Identificação da descrição do produto: o documento de descrição de produto deve possuir uma única identificação;

b) Identificaçăo do produto: A identificação do produto deve ter no mínimo o nome do produto e uma versäo ou data;

c) O fomecedor. a identificação do fomecedor deve conter o nome e o endereço de, no mínimo, um fomecedor,

Nota: o nome e endereço não precisam ser impressos; o cańmbo de um fomecedor/revendedor é suficiente.

d) Tarefa: identificação das tarefas que podem ser realizadas utilizando o produto;

e) Conformidade a documentos de requisitos: a descriçăo do produto pode fazer referência aos documentos de requisitos com os quais o produto está em conformidade. Nesse caso as edições relevantes devem ser identificadas;

f) Requisitos de hardware e software: os requisitos para colocar o produto em uso devem ser especificados, incluindo nomes de fabricantes e ldentificação do tipo de todos os componentes; 
g) Interface com outros produtos: se a descrição do produto faz referências a interfaces com outros produtos, as interfaces ou produtos devem ser identificados;

h) Itens a serem entregues: todo componente fisico do produto fornecido deve ser identificado, incluindo todos os documentos impressos e todos os meios de armazenamento de dados.

Nota: a formatação dos meios de armazenamento como por exemplo, formatação dos disquetes, não precisa ser indicada, uma vez que o conjunto de formatações possiveis é determinado pelos requisitos de hardware e software;

i) Instalação: deve ser declarado se a instalação do produto pode ou não ser conduzida pelo usuário;

j) Suporte: deve ser declarado se o suporte para operação do produto é oferecido ou não;

k) Manutenção: deve ser declarado se a manutenção é oferecida ou não. Em caso afirmativo deve ser declarado especificamente o que é incluido.

Declarações sobre Funcionalidade: esse item está divido em três subitens:

a) Visão geral das funções: a descrição do produto deve fornecer uma visão geral das funções disponiveis para o usuário do produto, os dados necessários e as facilidades oferecidas.

Nota: Nem toda função disponivel para o usuário necessita ser mencionada, e nem todos os detalhes de como uma função é chamada necessitam ser descritos.

b) Valores limite: se o uso do produto é limitado por valores limite específicos, estes devem ser fornecidos;

c) Segurança de acesso: convém que a descrição do produto inclua informaçōes a respeito de maneiras, se fornecidas, para evitar o acesso não autorizado (acidental ou intericional) a programas e dados.

Declaraçōes sobre Confiabilidade: a descrição do produto deve incluir informaçōes sobre procedimentos para preservação de dados. 
Nota: Uma declaração do tipo: "é possível fazer backup através de funções do sistema operacional" é suficiente na descrição do produto.

Convém que propriedades adicionais do produto sejam descritas para assegurar sua capacidade funcional. Como exemplo tem-se: verificar se a entrada é aceitável; proteger contra conseqüências danosas decorrentes de erro de usuário; recuperar erro;

Declaracões sobre Usabilidade: esse item está divido em cinco subitens:

a) Interface de usuário: deve ser especificado o tipo de interface com o usuário, como por exemplo, linha de comando, menu, janelas, teclas de função e função de auxilio;

b) Conhecimento requerido: deve ser descrito o conhecimento especifico requerido para a aplicação do produto;

c) Adaptação às necessidades do usuário: se o produto pode ser adaptado pelo usuário, entāo as ferramentas para essa adaptação e as condiçōes para seu uso devem ser identificadas. São exemplos: mudança de parâmetros, mudança de algoritmos para computação e atribuição de teclas de função;

d) Proteção contra infrações a direitos autorais: se a proteção técnica contra infraçōes a direitos autorais pode dificultar a usabilidade, então essa proteção deve ser declarada. São exemplos: proteção técnica contra cópias, datas programadas de expiração de uso, lembretes interativos para pagamento por cópia;

e) Eficiência de uso e satisfação de usuário: a descrição do produto deve incluir dados sobre a eficiência de uso e satisfação de usuário.

Declaraçōes sobre Eficiência: na descrição do produto podem ser incluidos dados sobre o comportamento do produto em relação ao tempo, tais como tempo de resposta e taxas de throughput para uma dada função sob condiçőes estabelecidas, como por exemplo, a configuração do sistema.

Declaraçōes sobre Manutenibilidade: pode conter declaraçōes sobre a manutenibilidade do produto. 
Declaraçöes sobre Portabilidade: pode conter declaraçōes sobre a portabilidade do produto.

\subsubsection{Manual do Usuário}

Quando um requisito de qualidade para pacote de software envolve o conjunto completo de documentos, disponivel na forma impressa ou não, que é fornecido para a utilização de um produto, sendo também uma parte integrante do produto, ele é denominado manual do usuário.

O manual do usuário deve incluir todos os dados necessários para a instalação (se necessário), para o uso da aplicação e para a manutenção do software produto.

O manual do usuário é um documento que será avaliado em relação à sua completitude, correção, consistência, inteligibilidade, apresentação e organização.

Completitude: deve conter todas as informaçōes necessárias para o uso do produto, tais como estabelecer todas as funções do pacote, procedimentos de instalação e os valores limite.

Correçāo: a informação apresentada deve estar correta e sem ambigüidade.

Consistência: deve haver plena coerência entre a documentação e a descrição do produto. Cada termo deve ter um único significado.

Inteligibilidade: a documentação deve ser compreensível pela classe de usuários que desenvolve atividades com o produto, utilizando termos apropriados, exibições gráficas $\theta$ explicaçōes detalhadas.

Apresentação e Organização: deve ser apresentada através de uma forma que facilite uma visão geral de índices e tabelas de conteúdo. Se o documento não está na forma impressa, deve haver indicação de como efetuar a impressão.

\subsubsection{Programas e Dados}

Os programas e dados são os requisitos de programas e dados que devem estar descritos, caso existam, para o funcionamento do produto. 
Os requisitos de qualidade para Programas e Dados utilizam as mesmas definiçס́es das características de qualidade da norma ISO/IEC 9126. As caracteristicas de Funcionalidade, Confiabilidade e Usabilidade são destacadas e devem ser verificadas através do uso do produto. Não há requisitos especificos para os aspectos de Eficiência, Manutenibilidade e Portabilidade. Qualquer requisito declarado na documentação do pacote, referente às características citadas, deve estar em conformidade. Os principais requisitos para Programas e Dados estão descritos a seguir:

Funcionalidade: devem ser verificados os procedimentos para instalação do produto; a presença de todas as funções mencionadas; a execução correta dessas funções; a ausência de contradições entre a descrição do produto e a documentação do usuário.

Confiabilidade: o usuário deve manter o controle do produto, sem corromper ou perder dados, mesmo que a capacidade declarada seja explorada até os limites ou fora deles, se uma entrada incorreta é efetuada, ou ainda se instruções explicitas na documentação são violadas.

Usabilidade: a comunicação entre o programa e o usuário deve ser de fácil entendimento, através das entradas de dados, mensagens e apresentação dos resultados, utilizando um vocabulário apropriado, representações gráficas e funções de auxílio (help), entre outras; o programa também deve proporcionar apresentação $\theta$ organização que facilitem uma visão geral das informações, além de procedimentos operacionais que o auxiliem, por exemplo, a reversão de uma função executada e o uso de recursos de hipertexto em funções de auxílio, entre outras.

\section{4 - Considerações Finais}

Neste capitulo foi apresentado um estudo das normas ISO/IEC 9126 e a NBR 12119 para avaliação da qualidade de produtos de software por serem elas utilizadas na elaboração da parte 4 da matriz Casa da Qualidade.

No próximo capítulo apresenta-se um processo de aquisição de conhecimerito, que será utilizado na elaboração das partes 1 e 2 da matriz Casa da Qualidade. 


\section{CAPÍTULO 4 - PROCESSO DE AQUISIÇÃO DE CONHECIMENTO}

\section{1 - Considerações Iniciais}

Neste trabalho utiliza-se para auxiliar a construção da matriz Casa da Qualidade um processo de aquisição de conhecimento denominado IPAIA, instanciado para o domínio QFD - Casa da Qualidade. Esse processo de aquisição de conhecimento foi desenvolvido a partir do processo IPAIA genérico o qual é apresentado neste capitulo. Também seräo apresentados os principais conceitos relacionados a aquisição de conhecimento.

\section{2 - Aquisição de Conhecimento}

A expressão "aquisição de conhecimento" corresponde a todos os mecanismos para adquirir conhecimento a ser utilizado na modelagem de um domínio de conhecimento. Podese dizer também, que a aquisição de conhecimento è o processo que visa obter toda a informação necessána para a construção de uma base de conhecimento para sistemas inteligentes [Rezende \& Pugliesi, 1998]. 
Em [Goonatilake \& Khebbal, 1995] a aquisição de conhecimento é descrita como um processo envolvendo a extração, interpretação e representação do conhecimento de um dado domínio, e é considerada como sendo o estágio mais dificil e precário no desenvolvimento de sistemas inteligentes.

Os membros envolvidos na aquisição de conhecimento são: Engenheiro de Conhecimento, Especialista de Domínio e os Clientes.

O engenheiro de conhecimento é o profissional responsável pela elaboração de um plano para aquisição de conhecimento explícito e pela aquisição de conhecimento propriamente dita. Sua tarefa primordial é extrair o conhecimento do(s) especialista(s) de domínio, ou de outra fonte - Clientes, relatórios, livros, manuais e dados entre outros interpretá-lo e representá-lo em uma base de conhecimento.

O especialista de domínio é o profissional selecionado devido à sua especialidade em um determinado domínio e sua habilidade em transpor seu conhecimento. Na extração de conhecimento, os especialistas de domínio se destacam devido às suas experiências no domínio do problema e ao alto grau de conhecimento.

Os clientes têm, de forma geral, uma boa visão do domínio em questão e podem fornecer informações de teor valioso durante as investigações iniciais.

O processo de aquisição de conhecimento pode ser realizado de forma manual, conhecido como aquisição de conhecimento explícito, elicitação ou eliciação de conhecimento, ou automática, conhecido como aquisição de conhecimento implícito.

No contexto do processo IPAIA utiliza-se apenas a aquisição de conhecimento explícito. Existem técnicas apropriadas para o processo de aquisição de conhecimento explícito, tais como entrevista, análise de protocolos, rastreamento de processo, brainstorming, repertónio grid, estudo de casos, introspecção e cenários. Neste trabalho são utilizadas as técnicas de entrevista e de brainstorming [McGraw \& Briggs, 1989; Cooke, 1994; Tuthill, 1990].

Entrevista é a técnica mais comum utilizada por engenheiros de conhecimento para elicitação - a partir de especialistas - de conhecimento do dominio em questäo. Utilizada nos estágios iniciais da aquisição de conhecimento, permite que o engenheiro de conhecimento compreenda, rapidamente, os conceitos e vocabulário do domínio. 
Durante a entrevista (1) o engenheiro de conhecimento deve deixar claro o propósito do envolvimento dos entrevistados na sessão; (2) as informaçōes podem ser registradas como notas, em áudio-tape ou video-tape; (3) situações, instâncias e problemas especificos são bem mais fáceis de serem conduzidos; (4) o especialista de domínio não deve ser forçado a produzir informaçōes de maneira determinada pelo engenheiro de conhecimento na qual ele não entende o método - é melhor usar uma representação natural e depois transportar as informações para uma representação devida; (5) o engenheiro de conhecimento deve tentar não interromper o raciocinio do especialista de domínio, mesmo que esse repita as informações várias vezes [Kidd, 1987].

As entrevistas podem ser do tipo:

- desestruturada: é apropriada quando o engenheiro de conhecimento precisa explorar um problema em questão durante, principalmente, as fases iniciais. Raramente produz descrições completas e bem organizadas do processo cognitivo. Trata-se de uma entrevista mais informal;

- estruturada: é apropriada quando o engenheiro de conhecimento deseja informações especificas do conteúdo ou o esclarecimento de uma questão. Este tipo de entrevista é orientada a objetivos e os resultados são mais úteis para a base de conhecimento.

Brainstorming é uma técnica de solução partilhada de problemas na qual todos os membros de um grupo contribuem espontaneamente com idéias, ou seja, é um processo designado a obter o número máximo de idéias relacionadas a uma área de interesse especifica.

A técnica do brainstorming (ou tempestade de idéias) foi originalmente desenvolvido por Alex Osbom em 1930, e sem dúvida é a precursora de muitas idéias existentes nos dias atuais.

Essa técnica é baseada em dois princípios e quatro regras básicas. 0 primeiro principio é o da suspensão do julgamento. $O$ objetivo da suspensão de julgamento é o de possibilitar a geração de idéias, sobrepujando o pensamento de julgar e criticar. Só após a geração de idéias consideradas suficientes, é que se fará o julgamento de cada uma. 0 segundo princípio do brainstorming sugere que quantidade origina qualidade. Quanto maior o número de idéias geradas, maior será a possibilidade de encontrar a solução do problema. 
As quatro regras básicas para o êxito de uma sessão de brainstorming são:

- eliminar qualquer crítica, no primeiro momento do processo, para que não haja inibição nem bloqueios e ocorra o maior número de idéias;

- apresentar as idéias tal qual elas surgem na cabeça, sem rodeios, elaborações ou maiores considerações;

- no brainstorming, quantidade gera qualidade, portanto, quarto mais idéias surgirem, maior será a chance de se conseguir, diretamente ou por meio de associações, as idéias realmente boas;

- numa segunda etapa, feita a seleção das idéias, aquelas potencialmente boas devem ser aperfeiçoadas. Nesse processo, costumam surgir outras idéias.

O brainstorming faz brotar idéias presas nas mentes das pessoas. Reconhece-se que, existindo certas condições, as pessoas poderão participar de um processo criativo que é autorealizador e melhora a qualidade do trabalho.

O brainstorming pode ser realizado de duas formas:

- estruturado: onde todos os membros do grupo devem dar uma idéia a cada rodada da sessão;

- não estruturado: onde os membros do grupo simplesmente dão idéias conforme elas surgem em suas mentes.

\section{3 - Processo de Aquisição de Conhecimento IPAIA}

A extração, interpretação e representação do conhecimento de um dado domínio é realizada utilizando-se um Processo de Aquisição de Conhecimento. Foi criado um Processo de Aquisição de Conhecimento - IPAIA (acrônimo) [Jubileu, 1999] onde a estrutura foi baseada na idéia de melhoramento contínuo de processo do Modelo IDEAL [Gremba, 1998].

Ó processo de Aquisição de Conhecimento IPAIA apresenta orientações que proporcionam uma abordagem de Aquisição de Conhecimento Explícito de uma maneira organizada. Esse processo pode ser direcionado tanto para grandes quanto para pequenos programas de Aquisição de Conhecimento e contém cinco fases: (1) Início do Processo de Aquisição de Conhecimento, (2) Preparação da Sessão de Aquisição de Conhecimento, (3) Aquisição do Conhecimento, (4) Implementação do Conhecimento e (5) Avaliação do 
Conhecimento. A fase 1 é realizada apenas uma vez, e as fases $2,3,4$ e 5 compöem uma etapa contínua de melhoramento do conhecimento, como mostrado na Figura 4.1 [Jubileu, 1999].

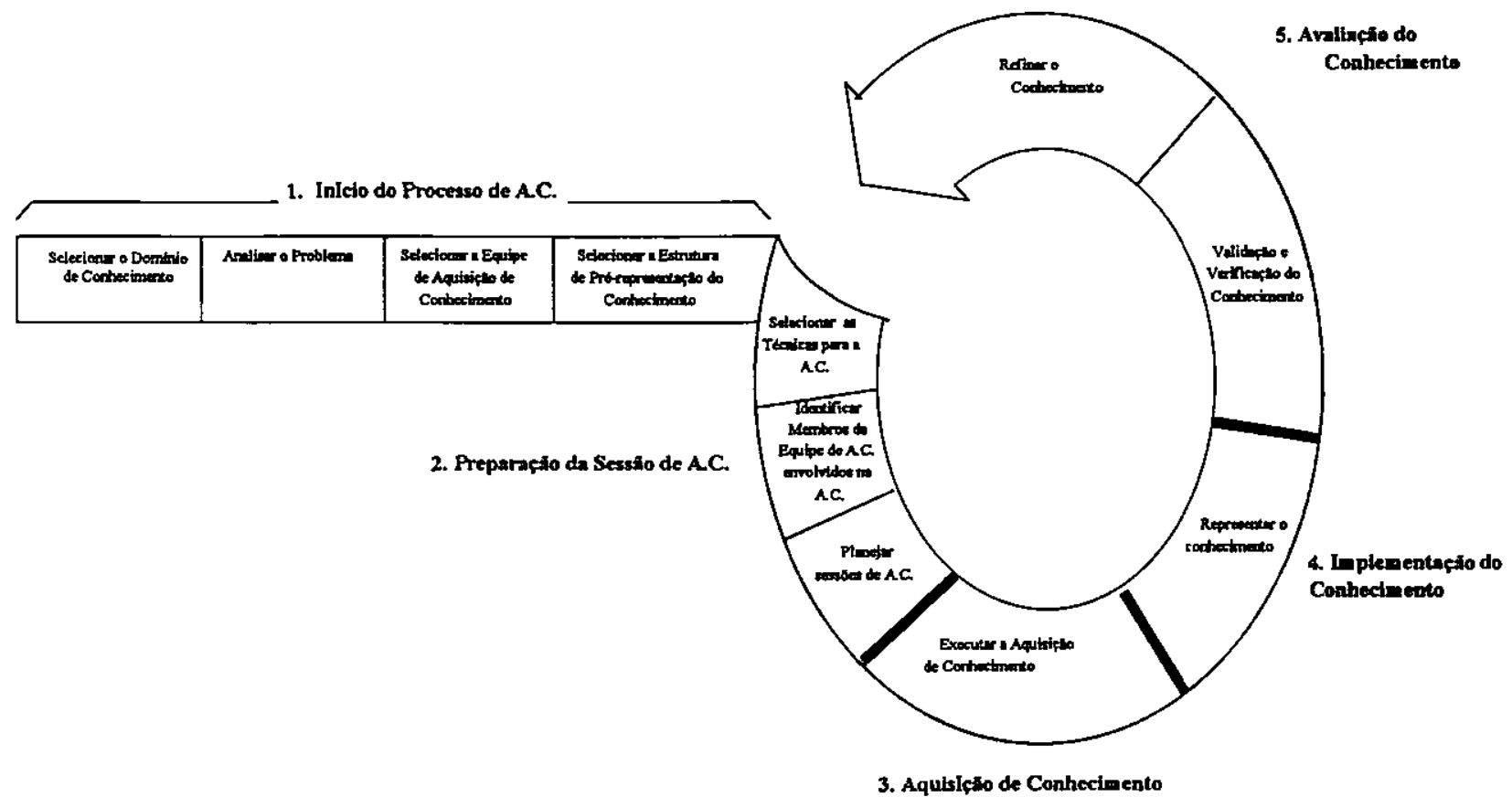

Figura 4.1 - Processo de Aquisição de Conhecimento IPAIA [Jubileu, 1999]

Fase 1 - Início do Processo de Aquisição de Conhecimento: esta fase descreve o domínio de conhecimento, termos chaves e referências. Também identifica um resumo simplificado dos conceitos relacionados ao domínio de conhecimento, para que as pessoas que tenham que interagir com o processo de Aquisição de Conhecimento possam compreendê-lo melhor. É desenvolvido um mapa mental do dominio de conhecimento, realizada a análise funcional na qual módulos distintos e entradas e saidas atuais são identificados, selecionada a equipe de Aquisição de Conhecimento e escolhida a estrutura de pré-representação do conhecimento dentro do domínio específico.

- Selecionar o Domínio de Conhecimento: a seleção de um dominio apropriado è crucial para o êxito no desenvolvimento de um Sistema Baseado em Computador. Os limites da tarefa devem ser claramente delineados; 
- Analisar o Problema: os termos chaves são importantes para se obter uma terminologia única entre os membros da equipe de Aquisição de Conhecimento; devem ser identificadas todas as referências que o processo de Aquisição de Conhecimento fizer a padrōes, procedimentos, terminologias ou outros documentos; os conceitos iniciais referentes ao dominio de conhecimento devem ser especificados; um mapa mental do domínio de conhecimento deve identificar relaçōes entre os conceitos e identificar as principais funçőes permitindo, assim, uma maior familiarização com o domínio do conhecimento; uma análise funcional pode ser realizada com o propósito de refletir a principal funcionalidade que o usuário deseja do sistema. A análise funcional é uma técnica que o Engenheiro de Conhecimento pode usar para estruturar os requisitos do sistema e delinear a sua funcionalidade. Na análise funcional devem ser identificados módulos distintos, entradas e saídas atuais. A ênfase nesta tarefa é traduzir os requisitos para um diagrama funcional inicial e descrever o relacionamento básico entre as funções. Usando diagramas de fluxo funcional, o Engenheiro de Conhecimento pode descrever sistemas maiores, subsistemas, requisitos de sistemas e interaçōes entre os componentes do sistema;

- Selecionar a Equipe de Aquisição de Conhecimento: uma característica fundamental para a formação da equipe de Aquisição de Conhecimento é uma boa interação, que é indispensável entre os componentes de qualquer grupo de trabalho, principalmente na situação aqui tratada, que envolve um processo dependente da motivação de todos os participantes. Uma equipe de Aquisição de Conhecimento normalmente é composta pelos seguintes membros: Gerente, Engenheiro de Conhecimento, Anotador/Assistente, Observador e Psicólogo;

- Selecionar a Estrutura de Pré-Representação do Conhecimento: a estrutura interna que representará o conhecimento deve ser elaborada de acordo com a necessidade da aplicação e/ou das definições do projeto do Sistema Baseado em Computador. Dentre estas estruturas estão regras de produção, redes semânticas, frames, scripts, entre outras.

Fase 2 - Preparação da Sessão de Aquisiçăo de Conhecimento: nesta fase são selecionadas as técnicas mais adequadas à aplicação, identificados os membros da equipe de Aquisição de Conhecimento envolvidos nas sessōes e planejadas as sessões de Aquisição de Conhecimento. 
- Selecionar as Técnicas para a Aquisiçăo de Conhecimento: muitas variáveis influenciam na seleção de técnicas de Aquisição de Conhecimento e o grau de estruturação com o qual elas são aplicadas. Entre essas variáveis estão: Tamanho e Meta do Programa de Aquisição de Conhecimento, Disponibilidade de Especialista(s) do Domínio, Quantidade e Experiência da Equipe de Aquisição de Conhecimento, e Tipo de Conhecimento.

- Tamanho e Meta do Programa de Aquisição de Conhecimento: programa de grande escala têm maior necessidade de estruturas e técnicas pré-determinadas do que programas menores. Por exemplo, numa fase inicial de Aquisição de Conhecimento podese utilizar as técnicas de Entrevista e Análise de Protocolos. Já nas sessões de Feedback e Refinamento, pode ser utilizado o Rastreamento de Processo seguido pela Entrevista Estruturada. Nas sessões aprofundadas de Aquisição de Conhecimento podem ser utilizadas Entrevista Estruturada, Simulações e Protótipos de desenvolvimento. A meta do programa de Aquisição de Conhecimento e a funcionalidade do Sistema Baseado em Conhecimento têm impacto sobre o tipo de técnicas de Aquisição de Conhecimento que serão selecionadas;

- Disponibilidade de Especialista(s) do Domínio: as técnicas também são selecionadas de acordo com o tempo que um especialista dispõe para um programa de Aquisição de Conhecimento. Isso não desconsidera o fato de que em alguns casos, a técnica mais apropriada requererá um tempo maior que aquele que o especialista tem disponível. Nesses casos deve haver uma negociação. Deve-se considerar, também, o fato de que o tempo disponibilizado a um programa de Aquisição de Conhecimento depende da complexidade do domínio do conhecimento em questão;

- Quartidade e Experiência da Equipe de Aquisição de Conhecimento: além da quantidade de membros da equipe de $A C$ disponiveis e da experiência dos mesmos com Aquisição de Corhecimento, um outro aspecto considerado no esforço dessa aquisição é - grau de compatibilidade entre as técricas de Aquisição de Conhecimento e a experiência ou capacidade atual do Engenheiro de Conhecimento com as mesmas;

- Tipo de Conhecimento: é importante caracterizar e combinar os tipos de conhecimento com as técnicas de Aquisição de Conhecimento apropriadas. Os tipos de conhecimento são declarativo, procedural, semântico e episódico. No conhecimento declarativo, identificam-se heurísticas gerais que são avaliáveis num nivel consciente ("sabendo que ${ }^{n}$ ), geralmente em memória de curto prazo, e são expressas de forma verbal. No 
conhecimento procedural, identificam-se tarefas/procedimentos de rotina. Este conhecimento inclui a habilidade de um individuo de "como" realizar algo, envolve uma resposta automática para um estímulo e. pode ser de natureza reacionária. No conhecimento semântico, identificam-se principais conceitos, ou seja, o vocabulário, procedimentos de decisão e heuristicas avaliáveis num nivel inconsciente. Este conhecimento é de grande importância ao(s) Engenheiro(s) de Corthecimento, reflete a estrutura de aprendizado, organização e representação, e representa um conhecimento de memória de longo prazo. No conhecimento episódico, identificam-se heurísticas de resolução de problemas análogos. Este conhecimento reside em memória de longo prazo e contém informações sobre "episódicos ou itens temporariamente datados e relaçōes temporais entre estes itens";

- Identificar Membros da Equipe de Aquisição de Conhecimento Envolvidos na Aquisição de Conhecimento: inclui indicar quem deve acompanhar as atividades. Cada uma das tarefas de Aquisição de Conhecimento deve ter um membro responsável. É recomendável que se registrem os atributos necessánios e desejáveis para quem ocupa cada cargo;

- Planejar Sessóes de Aquisição de Conhecimento: esta tarefa tem por finalidade criar, efetivamente, um instrumento de auxílio à Aquisição de Conhecimento e planejar como as sessões de Aquisição de Conhecimento serão conduzidas;

Fase 3 - Aquisição do Conhecimento: esta fase tem como objetivo adquirir os corhhecimentos que serão armazenados na Base de Conhecimento, ou seja, é a fase de execução do planejamento realizado na etapa anterior.

Fase 4 - Implementação do Conhecimento: nesta fase, o conhecimento adquirido deve ser representado formalmente. Para isso utiliza-se a estrutura de representação do conhecimento selecionada na Fase 1 deste Processo de Aquisição de Conhecimento.

Fase 5 - Avaliação do Conhecimento: nesta fase é realizada a verificação e validação (V\&V) do conhecimento que será refinado posteriormente, averiguando se o conhecimento existente é suficiente e correto. O conhecimento é considerado suficiente de acordo com o objetivo da Aquisição de Conhecimento.

Martin [McGRAW, 1989] descreve verificação como " construir o produto corretamente" e validação como "construir o produto certo". As atividades de V\&V são um dos componentes que asseguram a garantia de qualidade e confiabilidade do conhecimento adquirido. Teste é 
uma das atividades que pode ser utilizada na verificação e validação de produtos. Os testes para localizar potenciais problemas na Aquisição de Conhecimento podem ser estáticos e dinâmicos. A forma mais comum de teste estático refere-se à checagem, por parte dos Especialistas do Domínio, da consistência e completitude do conhecimento conceitual do domínio adquirido, $e$ teste dinâmico refere-se à identificação de valores críticos e casos a serem executados [Wilson, 1999; Andert, 1999].

Um aspecto crucial para a verificação da Base de Conhecimento é determinar se a transformação de conhecimento é exata, considerando a sua forma origirnal, passando por uma ou mais representações intermediárias, até a sua representação final (computável). Porém, ainda não existe uma técnica amplamente aceita para garantir a corretitude dessa transformação. Algumas técnicas utilizadas incluem inspeçōes/walkthroughs com outros Engenheiros de Conhecimento e execução "limitada" para permitir que o especialista veja o resultado de empregar o conhecimento.

As técnicas de V\&V são usadas para identificar redundâncias, contradiçōes, ciclos (por exemplo, o conhecimento $X$ infere no $Y$ que por sua vez infere no $X$ novamente) que geralmente indicam falhas na Base de Conhecimento e conclusões inalcançáveis que ocupam espaço desnecessário na mesma, e indicam problemas na lógica. Essas redundâncias, contradiçōes, ciclos e conclusōes inalcançáveis devem ser removidas para tornar a Base de Conhecimento mais eficiente.

\section{4 - Considerações Finais}

Neste capítulo foram apresentados alguns conceitos relacionados a aquisição de conhecimento, enfatizadas algumas técnicas de aquisição de conhecimento explícito que podem ser utilizadas durante o processo de aquisição de conhecimento e as fases do processo de Aquisição de Conhecimento IPAIA que pode ser utilizado em qualquer domínio de conhecimento.

No próximo capítulo é apresentada uma estratégia para elaboração da matriz Casa da Qualidade. Nessa estratégia o processo de aquisição de conhecimento IPAIA é instanciado para o domínio QFD - Casa da Qualidade. 


\section{CAPÍTULO 5 - ELABORAÇÃO DA MATRIZ CASA DA QUALIDADE}

\section{1 - Consideraçōes İniciais}

Neste trabalho, á matriz' Casa da Qualidade é gerada em quatro etapas. Na primeira etapa, determina-se os réquisitos do cliente, e o grau de importância dessés requisitos. $\mathrm{Na}$ segunda etápa, determina-se os requisitos de produto. Na terceira etapa, elabora-se a matriz de relacionamentos e na quarta etapa, faz-se a geração do grau de importância das características de pacote de software.

Para auxiliar a primeira etapa, instanciou-se o processo de aquisiçã́o de-conhẻcimènto IPAIA para o domínio QFD - Casa da Qualidâde. Neste capítulo, sãó apresentados o processo de aquisiçăò de conhecimento IPAIA, instanciado para o domínio QFD - Casa da Qualidade e a estratégiá pąąalabofação da matriz-Casa-da Qualidade.

\section{2 - Processo de Aquisição de Conhecimento IPAIA, Instanciado para o Domínio QFD - Casa da Qualidade}

O processo para Aquisição de Conhecimento Explícito - IPAIA [Jubileu, 1999] tem âmbito geral, podendo ser utilizado em qualquer domínio de conhecimento. 
O processo de aquisição de conhecimento IPAIA, como dito no Capítulo anterior, contém cinco fases: (1) Início do Processo de Aquisição de Conhecimento, (2) Preparação da Sessão de Aquisição de Conhecimento, (3) Aquisição de Conhecimento, (4) Implementação do Conhecimento e (5) Avaliação do Conhecimento. A primeira fase é realizada apenas uma vez, ao contrário das fases seguintes que são executadas tantas vezes quantas forem necessárias, com o intuito de lapidar cada vez mais o conhecimento das necessidades do cliente.

Na instanciação do processo para o domínio QFD - Casa da Qualidade eliminou-se da fase 1 a atividade análise do problema, pois nem sempre o Cliente tem a Visão Geral do Domínio de Conhecimento do Pacote a ser adquirido. O cliente, muitas vezes, não conhece os termos chaves para se obter uma terminologia única entre os membros da equipe de aquisição de conhecimento. As outras atividades da fase 1 são mantidas, pois são críticas para os esforços e recursos nas fases subsequentes.

A Figura 5.1 representa a instanciação do processo IPAIA para o domínio QFD - Casa da Qualidade.

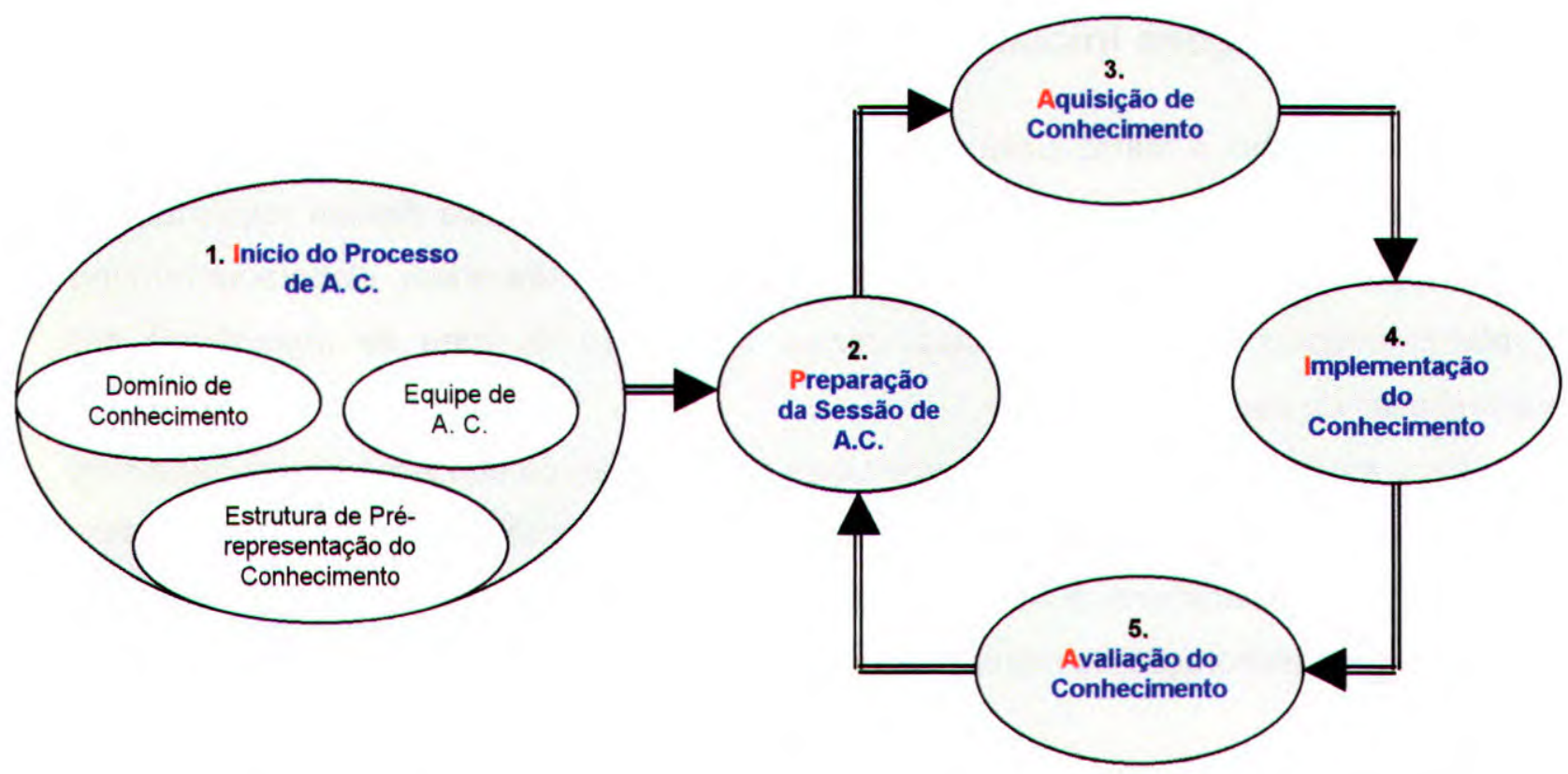

Figura 5.1 - Processo de Aquisição de Conhecimento IPAIA instanciado 


\section{- Fase 1 - Início do Processo de Aquisição de Conhecimento}

$\mathrm{Na}$ fase inicial do processo de aquisição de conhecimento IPAIA, instanciado para o domínio QFD - Casa da Qualidade (Figura 5.2) deve-se fornecer uma base sólida para o sucesso na Aquisição de Conhecimento. Essa fase ocorre apenas uma vez.

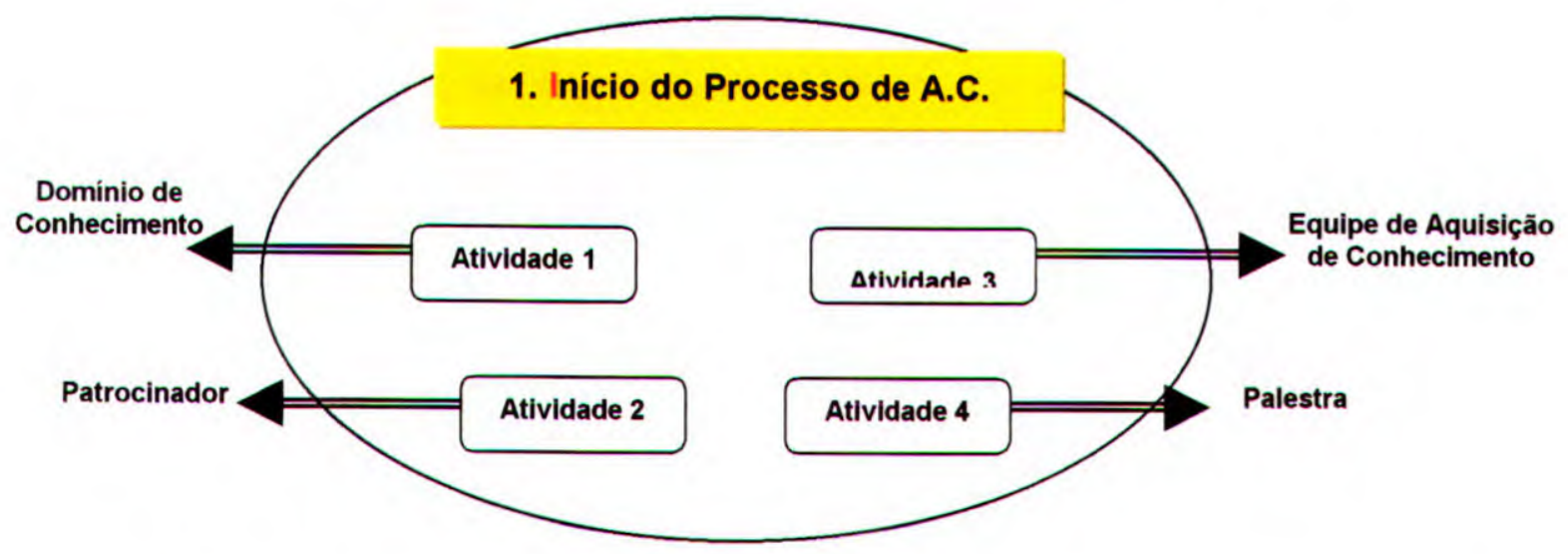

Figura 5.2 - Fase 1 do Processo de Aquisição de Conhecimento IPAIA Instanciado

Atividade 1 - Selecionar a área de aplicação do Pacote a ser adquirido, estabelecendo-se os limites do domínio de conhecimento;

Atividade 2 - Definir o patrocinador que deve ajudar a manter o compromisso nos momentos de dificuldades e garantir os recursos essenciais utilizados durante a Aquisição de Conhecimento;

Atividade 3 - Selecionar os potenciais membros das sessões de Aquisição de Conhecimento. Dentre esses estão 0 Engenheiro de Conhecimento, os Anotadores/Assistentes, os possíveis Especialistas de Domínio e os Clientes. O Especialista de Domínio deve entender da aplicação à qual o Pacote a ser adquirido se refere. O Engenheiro de Conhecimento deve entender de avaliação de "software de prateleira", ser alguém que conheça o processo de aquisição de conhecimento IPAIA instanciado e que seja capaz de selecionar os Especialistas de Domínio considerando não apenas o potencial dos mesmos a respeito do domínio da aplicação, mas também as suas características de relacionamento interpessoal. 
Atividade 4 - Estimular os possiveis participantes das sessões de Aquisição de Conhecimento realizando uma palestra inicial que deve focalizar o que é Aquisição de Conhecimento, sua importância para a organização, os principais conceitos relacionados à Aquisição de Conhecimento como Especialistas de Domínio, Engenheiro de Conhecimento, entre outros.

As últimas quatro fases do processo IPAIA instanciado para o domínio QFD - Casa da Qualidade podem se repetir quantas vezes forem necessárias para a obtenção das necessidades do cliente. Cada repetição das quatro fases é denominada ciclo do processo. $\mathrm{Na}$ instanciação do processo IPAIA para o domínio QFD - Casa da Qualidade existem dois tipos de ciclos, o ciclo de Visão Geral das Principais Necessidades do Pacote e o ciclo de Determinação de Importância das Características do Pacote.

- Primeiro Ciclo do Processo IPAIA instanciado para o domínio QFD - Casa da Qualidade: Ciclo de Visão Geral das Principais Necessidades do Pacote

Esse ciclo tem como objetivos adquirir uma visão geral do domínio do conhecimento do Pacote a ser adquirido e uma visão detalhada das características desse Pacote. A visão geral envolve os termos chaves utilizados no domínio de conhecimento e as principais funções de um Pacote referentes a esse domínio. A visão detalhada envolve o conteúdo da descrição do produto, a documentação para o usuário e o funcionamento do produto. Essas visões podem ser obtidas a partir do Especialista do Domínio da aplicação e dos Clientes.

Nesse ciclo deseja-se conhecer as expectativas, os desejos declarados e os desejos implícitos do cliente, com relação ao software de prateleira que ele deseja adquirir. Para auxiliar essa atividade escolheu-se a técnica de brainstorming estruturado.

A Figura 5.3 sintetiza os passos do primeiro Ciclo de Aquisição de Conhecimento, detalhados a seguir. 


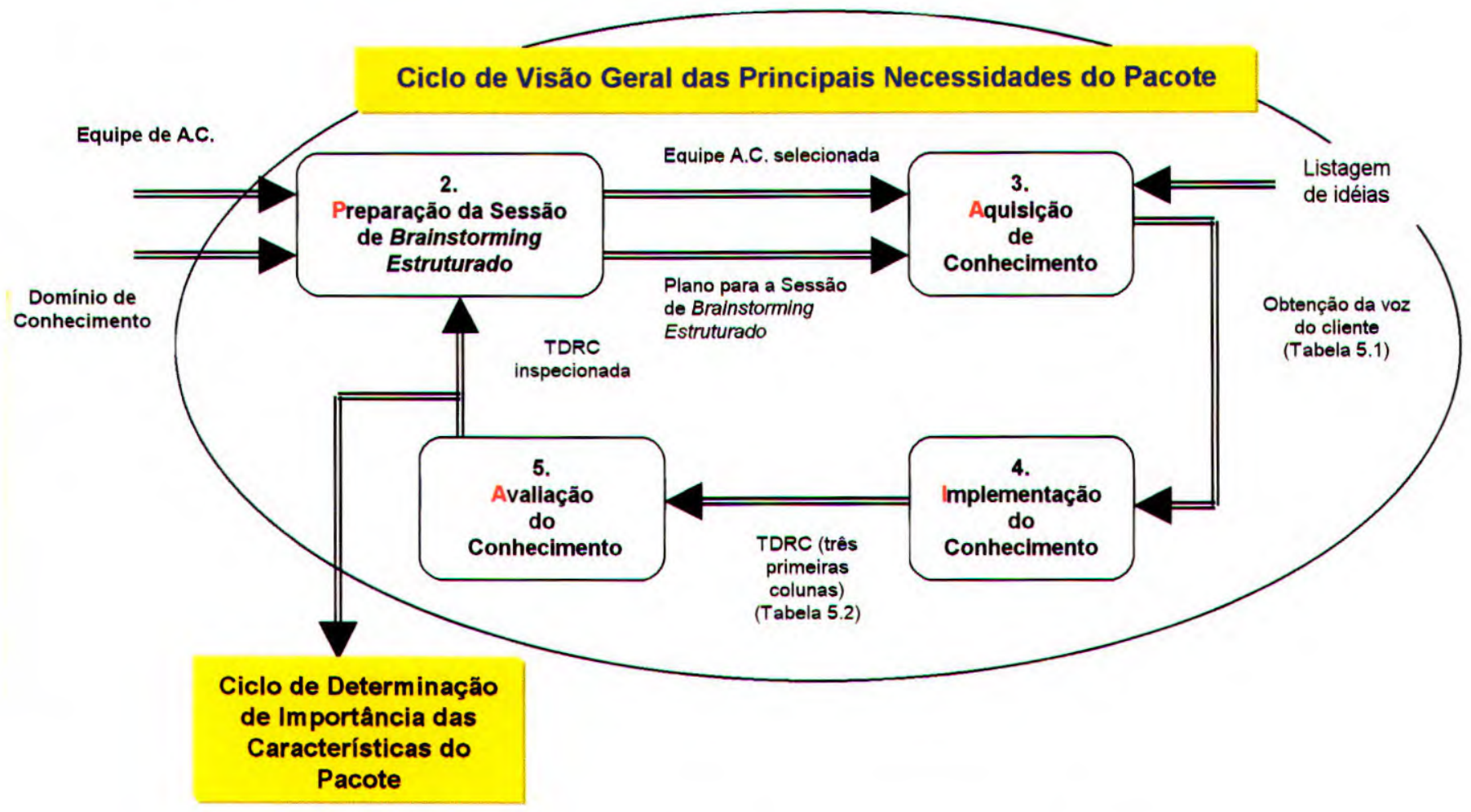

Figura 5.3 - Primeiro Ciclo de Aquisição de Conhecimento IPAIA Instanciado

\section{CICLO DE VISÃO GERAL DAS PRINCIPAIS NECESSIDADES DO PACOTE Fase de Preparação da Sessão de Brainstorming Estruturado}

Nessa fase são selecionados os membros que participarão da sessão de brainstorming estruturado e é elaborado um plano para auxiliar o Engenheiro de Conhecimento a conduzir a sessão de brainstorming.

Atividade 1 - Selecionar os membros que participarão da sessão de brainstorming estruturado: o Engenheiro de Conhecimento, o Especialista de Domínio, os Clientes e os Anotadores/Assistentes.

O Engenheiro de Conhecimento deverá selecionar dentre os potenciais membros selecionados na Fase 1, aqueles que realmente participarão da sessão. Essa seleção deve levar em consideração alguns problemas que normalmente ocorrem quando uma sessão de brainstorming é conduzida, além dos problemas referentes à Aquisição de Conhecimento propriamente dita. Esses problemas são sociais, tais como um grupo de pessoas 
que não contradizem seus superiores, pessoas que não dão sua opinião por temer "olhares negativos" de outros, pessoas com personalidade autoritária que dominam o grupo, etc. Por isso, devem ser escolhidos os membros considerados indivíduos democráticos direcionados aos objetivos do grupo [Wilson, 1999]. Também poderão fazer parte da sessão, pelo menos dois Anotadores/Assistentes que anotarão tudo o que está se passando durante a sessão.

Atividade 2 - Elaborar um plano de orientação para a sessão de brainstorming estruturado. No Quadro 5.1 é apresentada a estrutura do plano para conduzir essa sessão. Este plano deve ser entregue, com pelo menos dois dias de antecedência, para todos os participantes da sessão.

\section{CICLO DE VISÃO GERAL DAS PRINCIPAIS NECESSIDADES DO PACOTE Fase de Aquisição de Conhecimento}

Nessa fase o plano para a sessão de brainstorming estruturado, elaborado anteriormente, é colocado em prática para se adquirir os conhecimentos de âmbito geral a respeito do pacote a ser adquirido pelo cliente.

Durante a realização da sessão de brainstorming 0 anotador deve preencher 0 cabeçalho da Tabela 5.1 com os dados de identificação do cliente. O Engenheiro de Conhecimento deve perguntar aos Especialistas de Domínio quais são as suas exigências de qualidade para o pacote a ser adquirido. Como trata-se de brainstorming estruturado, utilizase uma listagem de idéias (Quadro 5.2 ) a partir da qual todos os membros do grupo expõem seus comentários. Para a criação da listagem de idéias considerou-se as características de qualidade da norma NBR 12119. As respostas devem ser anotadas na coluna "Dados Originais" da Tabela 5.1. A execução dessa primeira etapa tem como objetivo obter os dados originais, ou seja, captar a voz dos clientes.

A próxima etapa durante o processo de geração de idéias do brainstorming é extrair as reais exigências dos clientes, ou seja, converter os dados originais da segunda coluna para requisitos do cliente da quarta coluna (Tabela 5.1). A técnica desdobramento da cena auxilia nessa etapa, pois permite visualizar quem são os clientes, como o pacote será usado, onde será usado e porque será usado [Cheng, 1995; Cohen, 1937]. Pode-se utilizar também a imaginação para desdobrar novas cenas a partir dos dados originais emitidos pelos clientes. 
Quadro 5.1 - Estrutura do Plano para a Sessão de Brainstorming Estruturado

\section{PLANO PARA A SESSÃO DE BRAINSTORMING ESTRUTURADO}

1 Introdução: o objetivo deste plano é orientar o Engenheiro de Conhecimento a conduzir uma sessão de brainstorming estruturado:

2 Gerenciamento: devem ser identificados os dados gerais para a realização da sessão de brainstorming. estruturado:

Local da Sessão: <local físico onde ocorrerá a sessão>

Data da Sessão: $<\mathrm{dd} / \mathrm{mm} / a a>$ Horário: <hh:mm>

Tempo Total: 〈duração da sessão de Aquisição de Conhecimento〉

Engenheiro de Conhecimento: «nome>

Anotadores/Assistentes: 〈nome>

Especialista do Domínio/Fonte de Conhecimento: «nome do especialista

Cliente: snome do cliente>

$+x^{4}$

:

Meta da Sessão: adquirir uma visão geral do domínio do conhecimento do Pacote a ser adquirido e uma visão detalhada das características desse Pacote.

3 Tarefas:

3.1 O Engenheiro de Conhecimento deve deixar claro o motivo da participação de cada membro da equipe de Aquisição de Conhecimento, motivando-os e deixando-oș relaxados para que a sessão transcorra de forma efetiva. Além disso, deve deixar claro o seu papel durante a sessão e o papel dos Anotadores/Assistentes que devem registrar as informações relatadas tão logo apresentadas;

\section{Brainstorming Estruturado.}

3.2 Levantar uma das funcionalidades considerando o listagem de idéias (Quadro 5.2):

3.3 Solicitar que cada especialista exponha seu conhecimento a respeito da função levantada;

3.4 Anotar as respostas na coluna "Dados Originais" da Tabela 5.1;

3.5 Repetir as tarefas 3.2. 3.3 e 3.4 até que todas as funcionalidades identificadas tenham sido discutidas;

3.6 Converter os dados originais da segunda coiuna para requisitos do cliente da quarta coluna da Tabela 5.1.

4 Cronograma: é importante a elaboração de um cronograma para melhor utilizar o tempo não atrapalhando, assim, o cotidiano dos membros de Aquisição de Conhecimento.

5 Recursos: preparar o local selecionado dispondo as cadeiras de forma circular, para que todos se vejam, e distribuindo papel e caneta a todos os membros da sessão para anotações. Se no local houver uma mesa onde todos possam se posicionar em forma circular, ótimo; caso não haja mesa, serão necessárias pranchetas que servirão de apoio para escrever; 
O Engenheiro de Conhecimento deve exercer a função de moderador durante a Aquisição de Conhecimento: deve ponderar as discussões, não deixar ninguém interromper quando um dos Especialistas de Domínio estiver com a palavra, deve limitar o tempo para que cada um exponha suas informaçōes. Deve incentivar a participação dos membros do grupo $e$ o processo de geração de novas idéias. Deve, também, esclarecer algumas regras de brainstorming aos Especialistas de Domínio: esses não devem se preocupar com o modo de se expressar (escolher palavras), não devem se preocupar com a organização das palavras, devem escrever em qualquer ordem. Os participantes da reunião devem apresentar suas idéias naturalmente, à medida que elas vão surgindo, o que torna 0 ambiente mais informal. Não devem criticar, validar, julgar ou defender as informaçōes fomecidas por qualquer um dos membros de Aquisição de Conhecimento [Bouchard, 1999; KCl, 1999; Osbome, 1999]. As críticas podem inibir a participação de alguns membros do grupo.

Tabela 5.1 - Obtenção da Voz dos Clientes

\begin{tabular}{|c|c|c|c|}
\hline \multicolumn{4}{|c|}{$\begin{array}{l}\text { Pacote de Software : } \\
\text { Identificação dos Cllentes: }\end{array}$} \\
\hline $\mathrm{N}^{\circ}$ & DADOS ORIGINAIS & $\begin{array}{l}\text { DESDOBRAMENTO DA } \\
\text { CENA (Quem, Onde, } \\
\text { Quando, como, Por que, ...) }\end{array}$ & $\begin{array}{c}\text { REQUISITO DO CLIENTE } \\
\text { (cartäo) }\end{array}$ \\
\hline & & & \\
\hline & & & \\
\hline & & & \\
\hline & & & \\
\hline
\end{tabular}


Quadro 5.2 - Listagem de Idéias

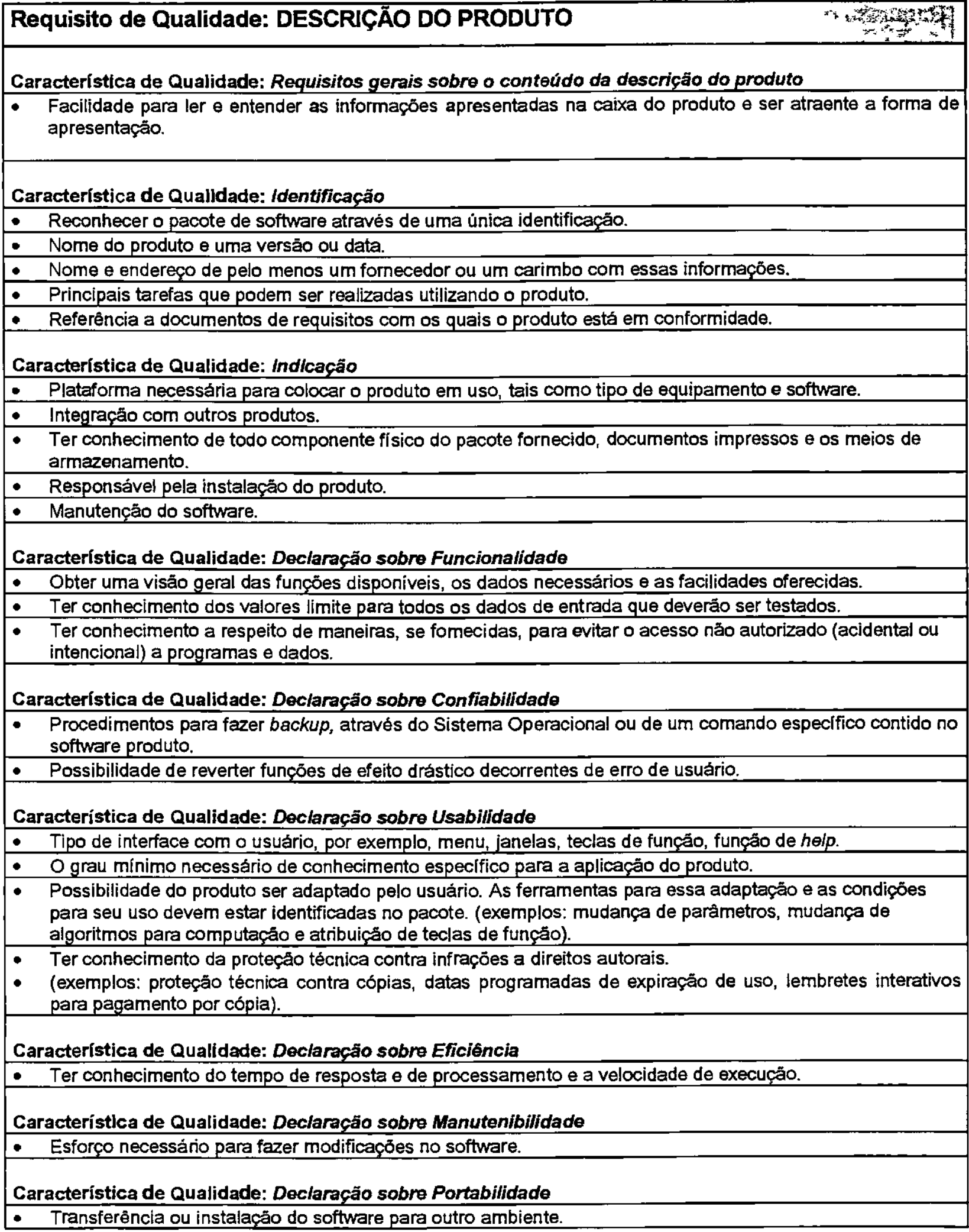




\section{Quadro 5.2 - Listagem de Idéias (continuaçāo)}

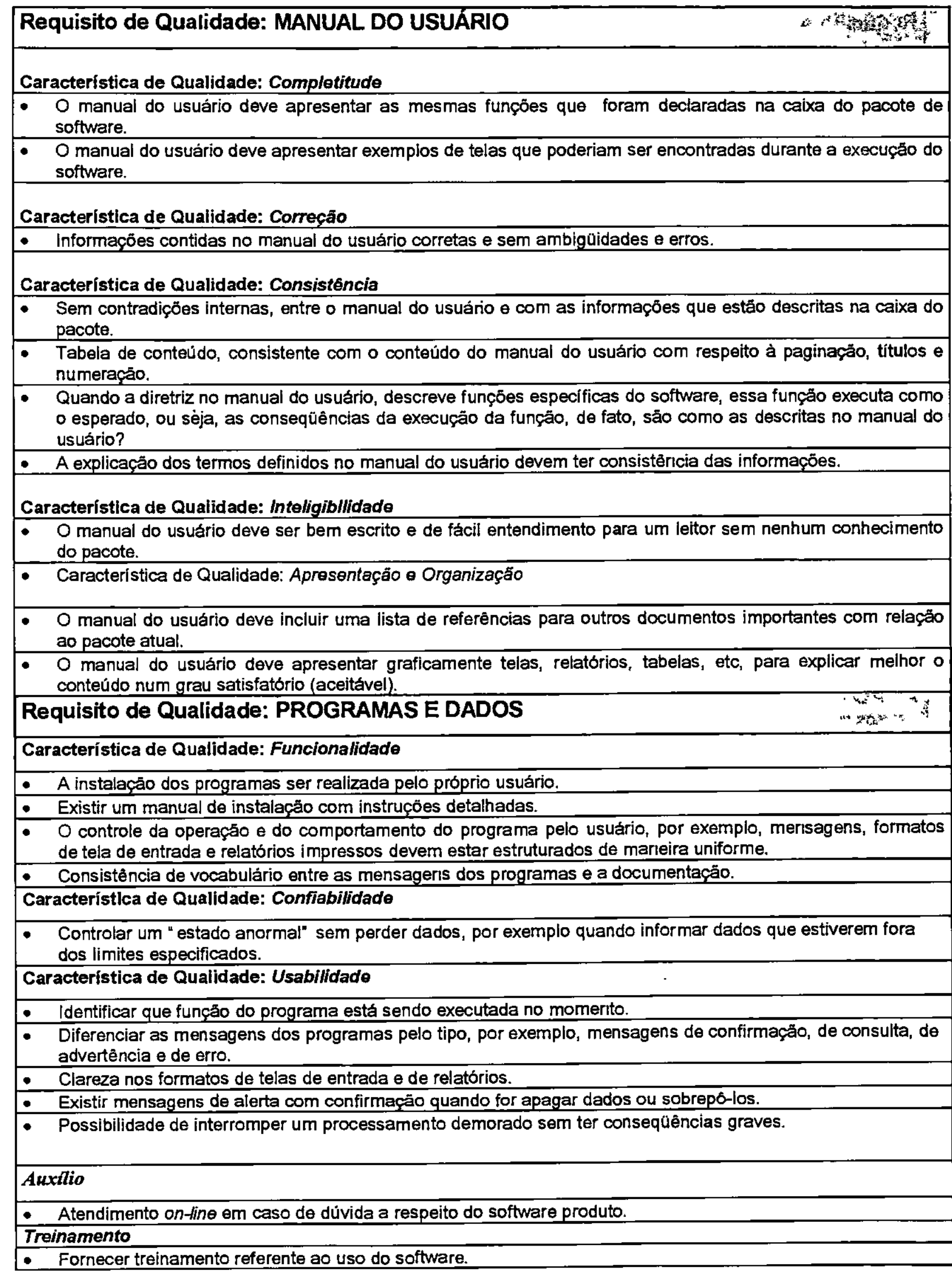




\section{CICLO DE VISÃO GERAL DAS PRINCIPAIS NECESSIDADES DO PACOTE}

Fase de Implementação do Conhecimento

Para realizar a implementação do conhecimento, duas etapas são realizadas:

Etapa 1: nessa etapa deve-se escrever cada requisito do cliente, mostrado na última coluna da Tabela 5.1, em um "cartão" para posterior agrupamento.

Etapa 2: nessa etapa é realizada a preparação da tabela de desdobramento dos requisitos do cliente. Na elaboração da tabela de desdobramento dos requisitos do cliente só são utilizados os itens da coluna "Requisito do Cliente" da Tabela 5.1. O Engenheiro de Conhecimento deve ler em voz alta, examinar e comparar esses itens. Se houver dois ou mais cartões com mesmo significado, selecionar aquele que melhor expresse o requisito do cliente e descartar os demais. Agrupar os itens similares de requisito do cliente, utilizando a técnica diagrama de afinidades, e escrever em um "cartão" um título que descreva cada grupo formado. Considerar esses títulos como itens de nível secundário e os elementos de cada grupo como de nivel terciário. Agrupar os itens secundários em grupos similares para formar itens primários e escrever os títulos de cada grupo em cartões. Nesse ciclo são preenchidas apenas as três primeiras colunas da tabela de desdobramento dos requisitos do cliente (Tabela 5.2). A coluna de grau de importância será preenchida no próximo ciclo. $\mathrm{Na}$ seqüência, deve-se fazer uma análise crítica de cada item em cada nível, verificando se são apropriados. Rearranjar, caso necessário, e completar a Tabela 5.2. No preenchimento da Tabela 5.2 não é obrigatório completar as três primeiras colunas, depende do nivel de detalhamento da informação desejada. Talvez seja suficiente representar a informação apenas no primeiro e segundo nível.

Tabela 5.2 - Tabela de Desdobramento dos Requisitos do Cliente (TDRC)

\begin{tabular}{|l|l|l|c|}
\hline Nível Primário & Nivel Secundário & Nivel Terciário & $\begin{array}{c}\text { Grau de } \\
\text { Importância }\end{array}$ \\
\hline \multirow{3}{*}{} & & & \\
\hline & & & \\
\cline { 3 - 4 } & & & \\
\cline { 3 - 5 } & & & \\
\cline { 3 - 5 } & & & \\
\hline
\end{tabular}


CICLO DE VISÃO GERAL DAS PRINCIPAIS NECESSIDADES DO PACOTE Fase de Avaliação do Conhecimento

Nessa fase, o conhecimento adquirido deve ser verificado e validado. A verificação do conhecimento refere-se à confiabilidade de representação. A validação refere-se à confiabilidade conceitual e é realizada por meio de uma inspeção [Wilson, 1999], [Andert, 1999]. Essa inspeção é realizada junto ao Especialista de Dominio, os Clientes e o Engenheiro de Conhecimento, a fim de checar a consistência e completitude do conhecimento conceitual do domínio adquirido.

Normalmente, uma sessão de brainstorming estruturado já é suficiente para o objetivo do ciclo. No entanto, se as informações ainda não foram suficientes para adquirir a Visão Geral das Principais Necessidades do Pacote, pode ser repetida outra sessão de brainstorming estruturado. Isso deve ocorrer até que se atinja o objetivo do ciclo de Visão Geral das Principais Necessidades do Pacote. Quando o objetivo do primeiro ciclo é atingido inicia-se o segundo ciclo do processo IPAIA instanciado: Ciclo de Determinação de Importância das Características do Pacote.

- Segundo Ciclo do Processo IPAIA instanciado para o domínio QFD - Casa da Qualidade: Ciclo de Determinação de Importância das Características do Pacote

O objetivo desse ciclo é adquirir o grau de importância para cada característica obtida no primeiro ciclo. O grau de importância deve ser obtido a partir do ponto de vista do Cliente. Assim, nesse ciclo é selecionada a técnica de entrevista estruturada com o Cliente. As questões formuladas na entrevista são baseadas na tabela de desdobramento dos requisitos do cliente (TDRC) quando então, o Cliente determinará o grau de importância de cada uma das características do Pacote. A escala de valores possiveis para o grau de importância deve seguir a escala de Likert'.

A Figura 5.4 sintetiza os passos do segundo Ciclo de Aquisição de Conhecimento, detalhados a seguir.

\footnotetext{
${ }^{1}$ A escala de Likert varia no intervalo de 1 a 5 sendo que 1 corresponde a nenhuma importância, 2 correspond pouca importância, 3 corresponde a alguma importância, 4 corresponde a importante e 5 corresponde a mu... importante
} 


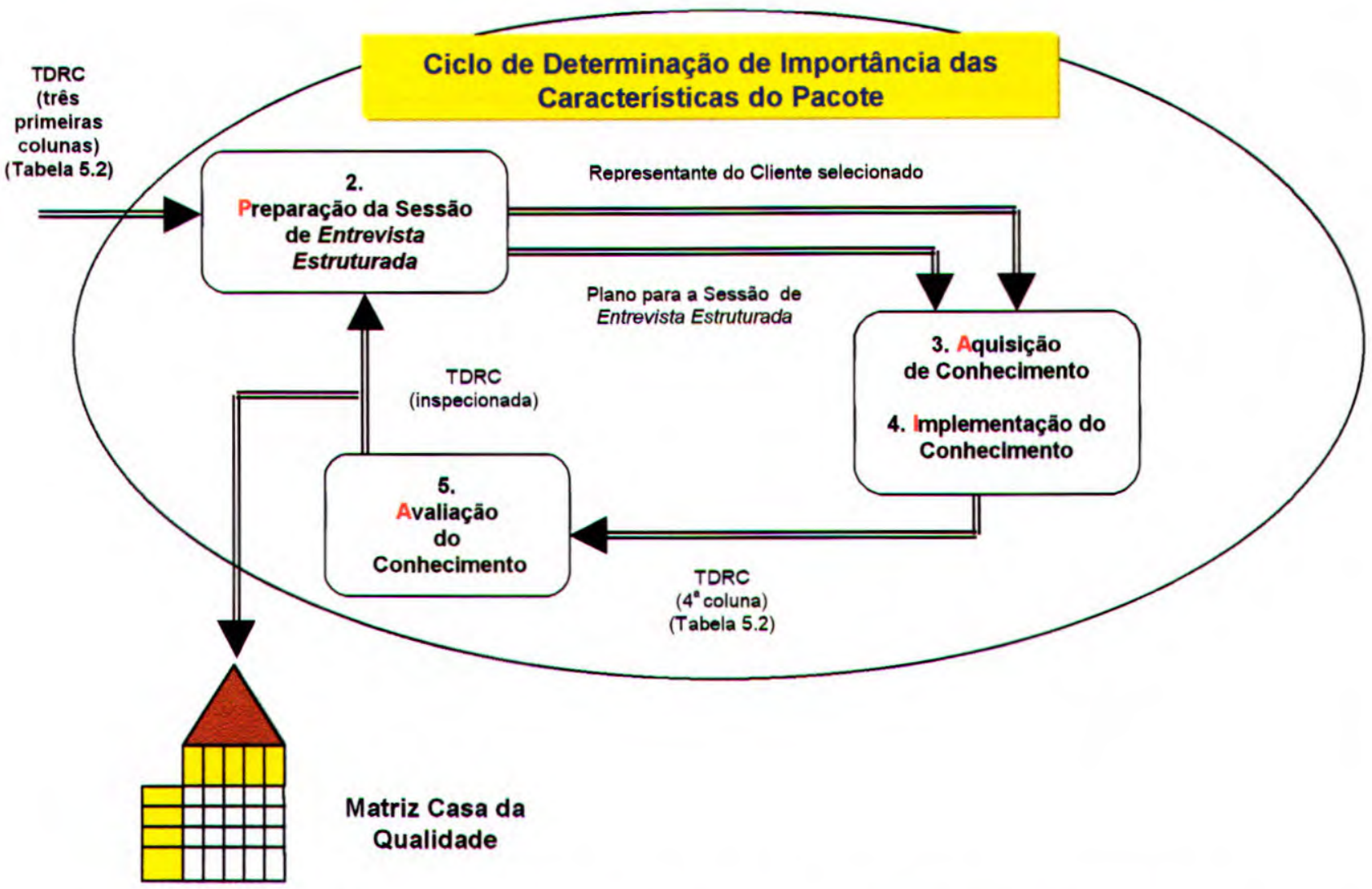

Figura 5.4 - Segundo Ciclo de Aquisição de Conhecimento IPAIA Instanciado

\section{CICLO DE DETERMINAÇÃO DE IMPORTÂNCIA DAS CARACTERÍSTICAS DO PACOTE Fase de Preparação da Sessão de Entrevista Estruturada}

Nessa fase é elaborado um plano para conduzir a sessão de entrevista estruturada. No Quadro 5.3 é apresentada a estrutura do plano para conduzir essa sessão. Este plano deve ser entregue com pelo menos dois dias de antecedência para o participante da entrevista.

Atividade 1 - Selecionar o representante do Cliente que participará da sessão de entrevista estruturada;

Atividade 2 - Elaborar um plano para orientar a condução da sessão de entrevista estruturada. 
Quadro 5.3 - Estrutura do Plano para a Sessão de Entrevista Estruturada

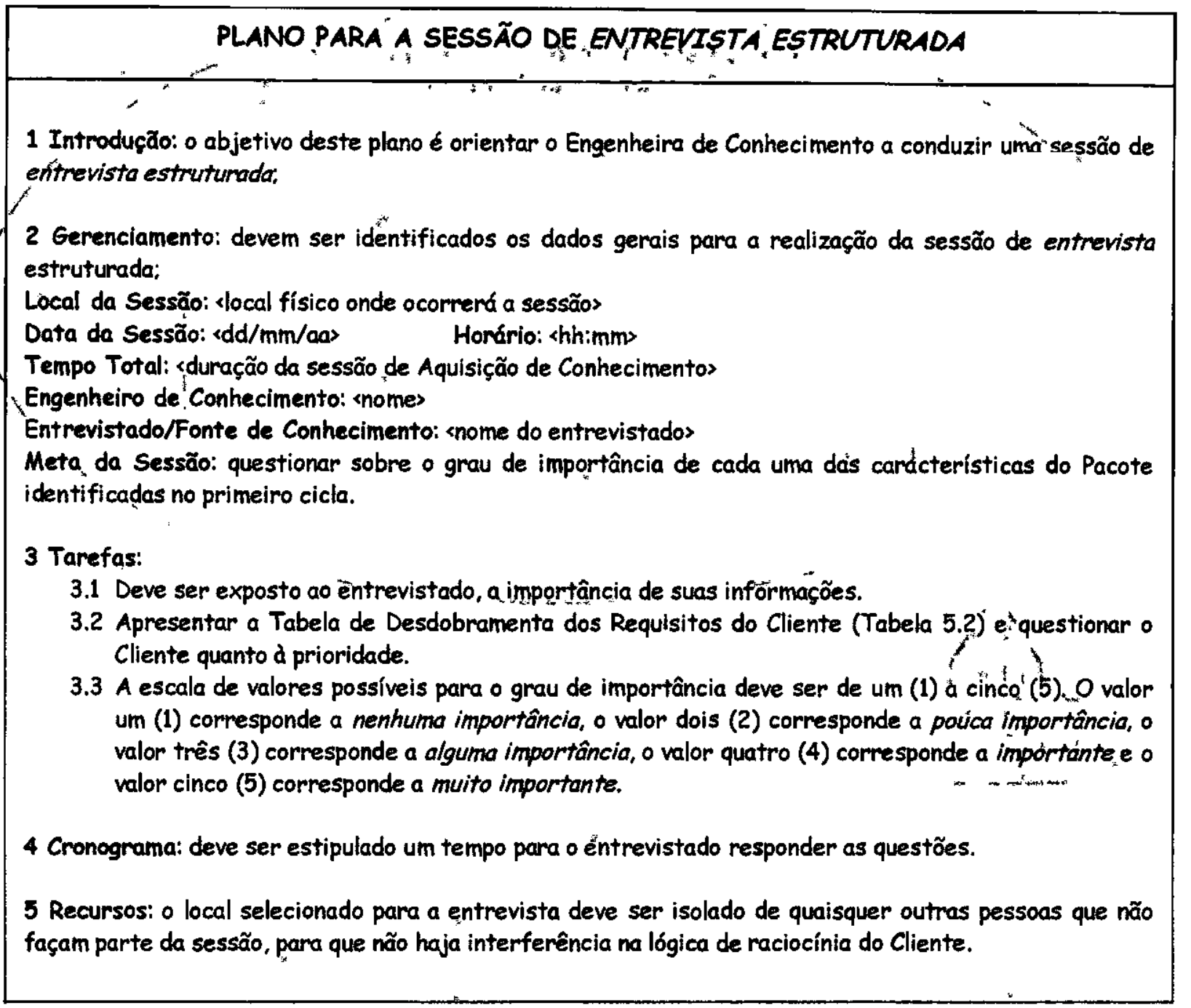

\section{CICLO DE DETERMINAÇÃO DE IMPORTÂNCIA DAS CARACTERÍSTICAS DO PACOTE Fase de Aquisição e Implementação de Conhecimento}

Nessa fase o plano para a sessão de entrevista estruturada, elaborado na etapa anterior, é colocado em prática a fim de se completar a tabela de desdobramento dos requisitos do cliente (Tabela 5.2), preenchendo-se a quarta coluna com o grau de importancia de cada uma das características do Pacote. 
CICLO DE DETERMINAÇÃO DE IMPORTÂNCIA DAS CARACTERÍSTICAS DO PACOTE Fase de Avaliação de Conhecimento

Nessa fase. conhecimento da tabela de desdobramento dos requisitos do cliente (TDRC) é verificado e validado. Isso é realizado conferindo a consistência $e_{i} c_{1} c_{i}^{\prime}$ 'mpletitude do conhecimento obtido anteriormente e junto ao Cliente.

\section{3 - Estratégia para Elaboração da Matriz Cas̄a da Quạlịdạj̧e}

A estratégia para elaboraçäo da matriz Casa da Qualidade é composta de quatro etapas:

- Requisitos do Cliente e o seu Grau de Importância

- Requisitos de Produto

- Matriz de Relacionamentos

- Geração do Grau de Importância das Caracteristicas de Pacote de Software

- Procedimento para Determinaçăo dos Requisitos do Cliente e do seu Grau de Importância

A determinação dos requisitos do cliente tem como objetivo captar a "voz do cliente", ou seja, os atributos que influenciam a percepção do cliente para a qualidade do pacote de software $\theta$ os pontos fortes $\theta$ fracos do mesmo com relação a esses atributos, sempre do ponto de vista do cliente.

A determinação do grau de importância tem como propósito atribuir pesos que representam a importância de cada requisito do cliente, no ponto de vista do cliente.

Para auxiliar a obtenção das necessidades e desejos do Cliente com relação às características do Pacote a ser adquirido e na determinação do grau de importância dessas características, utilizou-se o processo de aquisição de conhecimento IPAIA, instanciado para o domínio QFD - Casa da Qualidadø, apresentado na seção anterior.

A tabela de desdobramento dos requisitos do cliente produzida pelo processo de aquisição de conhecimento IPAIA, instanciado para o domínio QFD - Casa da Qualidade, determinam as "linhas" da matriz Casa da Qualidado. As informaçöes contidas na Tabela 5.2 que correspondem ao último nível de desdobramento dos requisitos do cliente e ao grau de importância, são transcritas para a área circundada da matriz Casa da Qualidade (Figura 5.5). 


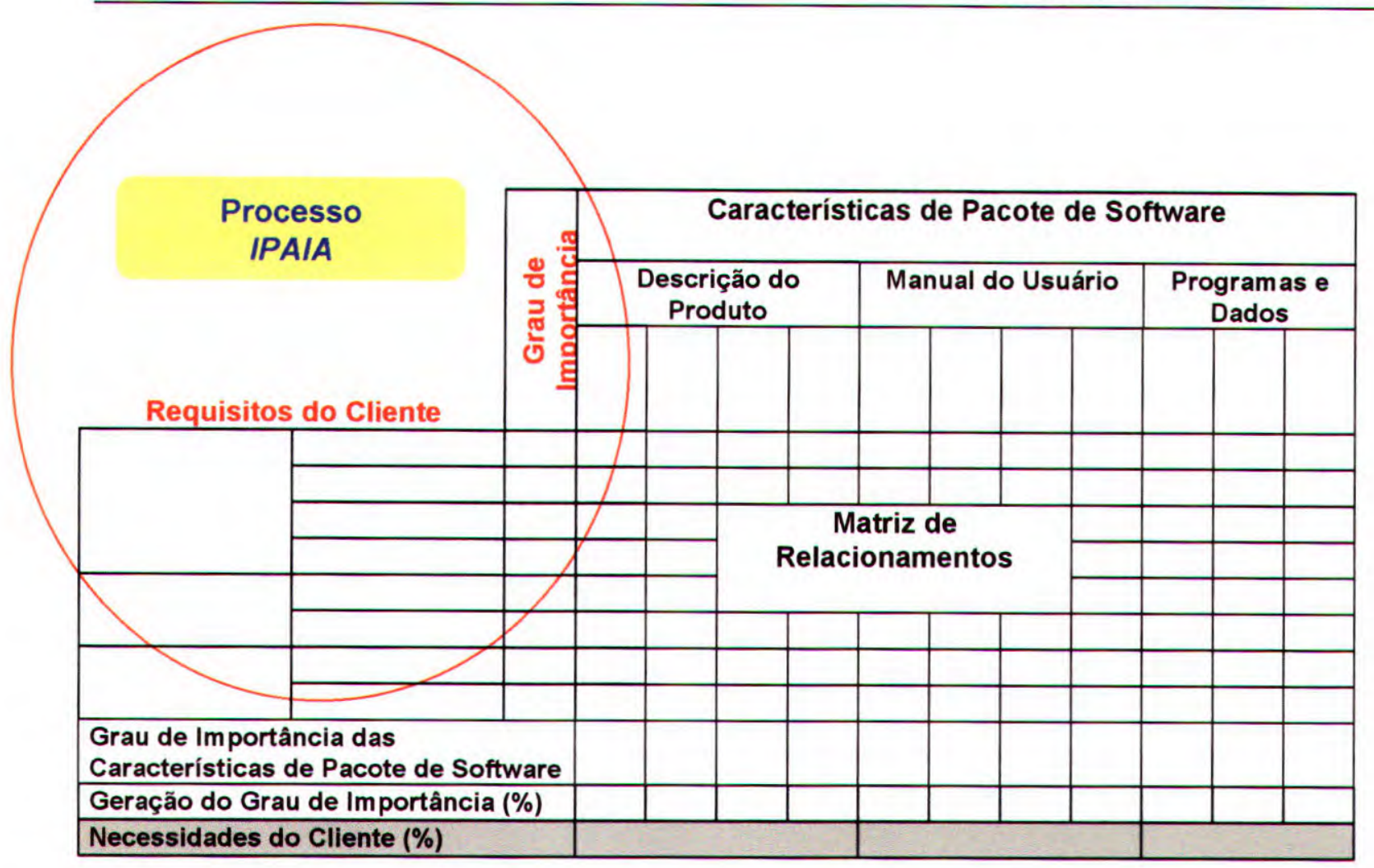

Figura 5.5 - Partes da matriz Casa da Qualidade - Requisitos do Cliente e o seu Grau de Importância

\section{- Procedimento para Determinação dos Requisitos de Produto}

Considerando-se O QFD "tradicional", na primeira matriz - Casa da Qualidade - os requisitos do cliente são transformados em requisitos de produto; na segunda matriz Desdobramento das Partes - os requisitos de produto são traduzidos em características das partes; na terceira matriz - Planejamento do Processo - as características das partes são traduzidas em operações de fabricação, e assim sucessivamente.

No caso deste trabalho, utiliza-se apenas a primeira matriz - Casa da Qualidade, como citado no item 2.3 do Capítulo 2. Nas "colunas" dessa matriz são colocadas as características de qualidade para pacote de software (norma NBR 12119): descrição do produto, manual do usuário e programas e dados (Figura 5.6). 


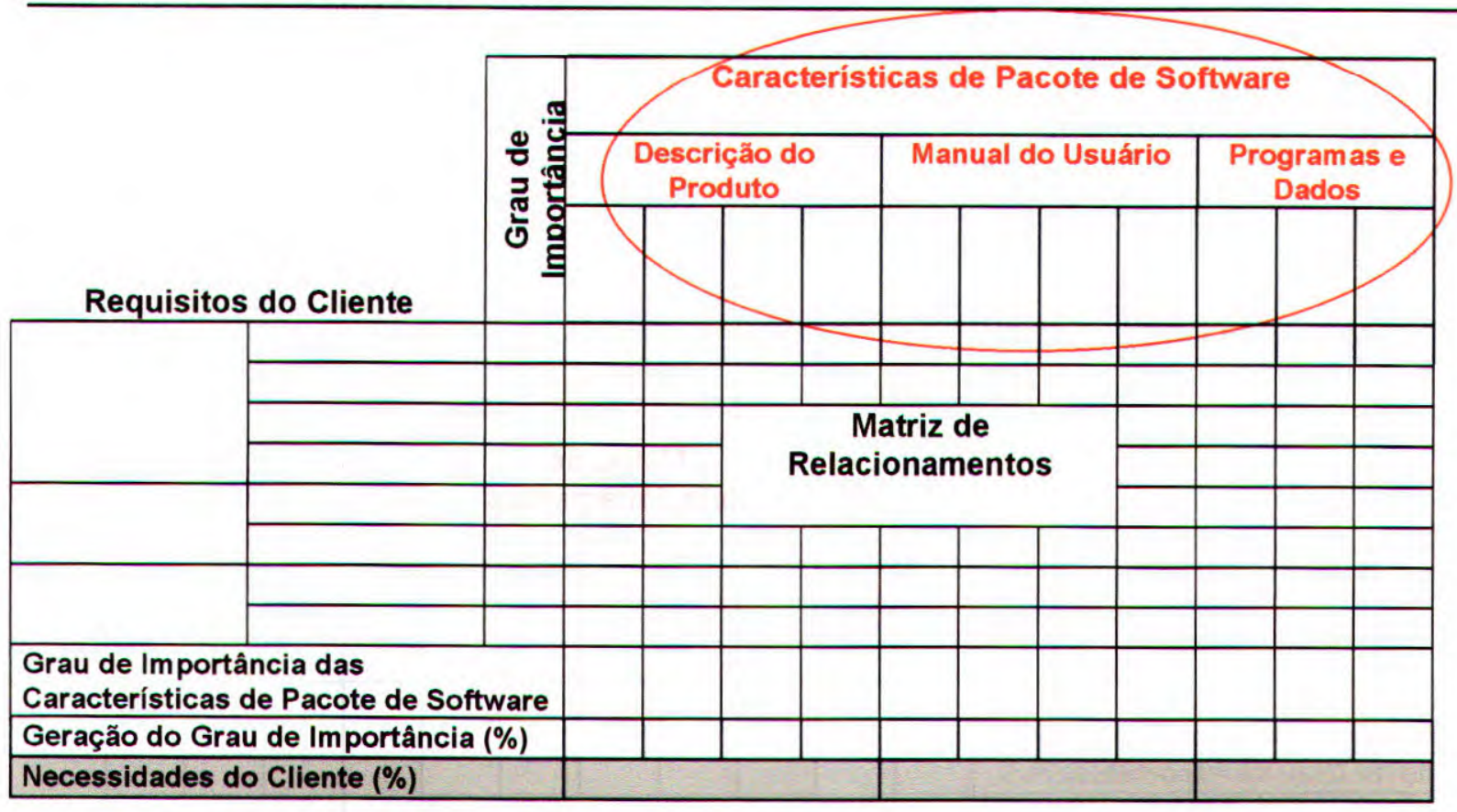

Figura 5.6 - Partes da matriz Casa da Qualidade - Características de Pacote de Software

\section{- Procedimento para Elaboração da Matriz de Relacionamentos}

O processo de correlação consiste em identificar o grau de influência ou interferência que os requisitos do cliente exercem sobre as características de pacote de software (Figura 5.7).

Para se executar a correlação entre os requisitos do cliente e as características de pacote de software, considera-se individualmente cada item dos requisitos do cliente e definese a sua correlação com todos os itens das características de pacote de software. Adota-se a seguinte escala para quantificar os relacionamentos: relacionamento forte vale nove (9) pontos, relacionamento moderado vale três (3) pontos e relacionamento fraco vale um (1) ponto.

O relacionamento forte significa que, com certeza, a característica de pacote de software avalia diretamente $o$ atendimento às necessidades do cliente.

O relacionamento moderado significa que, provavelmente, a característica de pacote de software possa avaliar o atendimento às necessidades do cliente.

O relacionamento fraco significa que há uma suspeita de que a característica de pacote de software possa avaliar, mesmo que indiretamente, o atendimento às necessidades do cliente. 


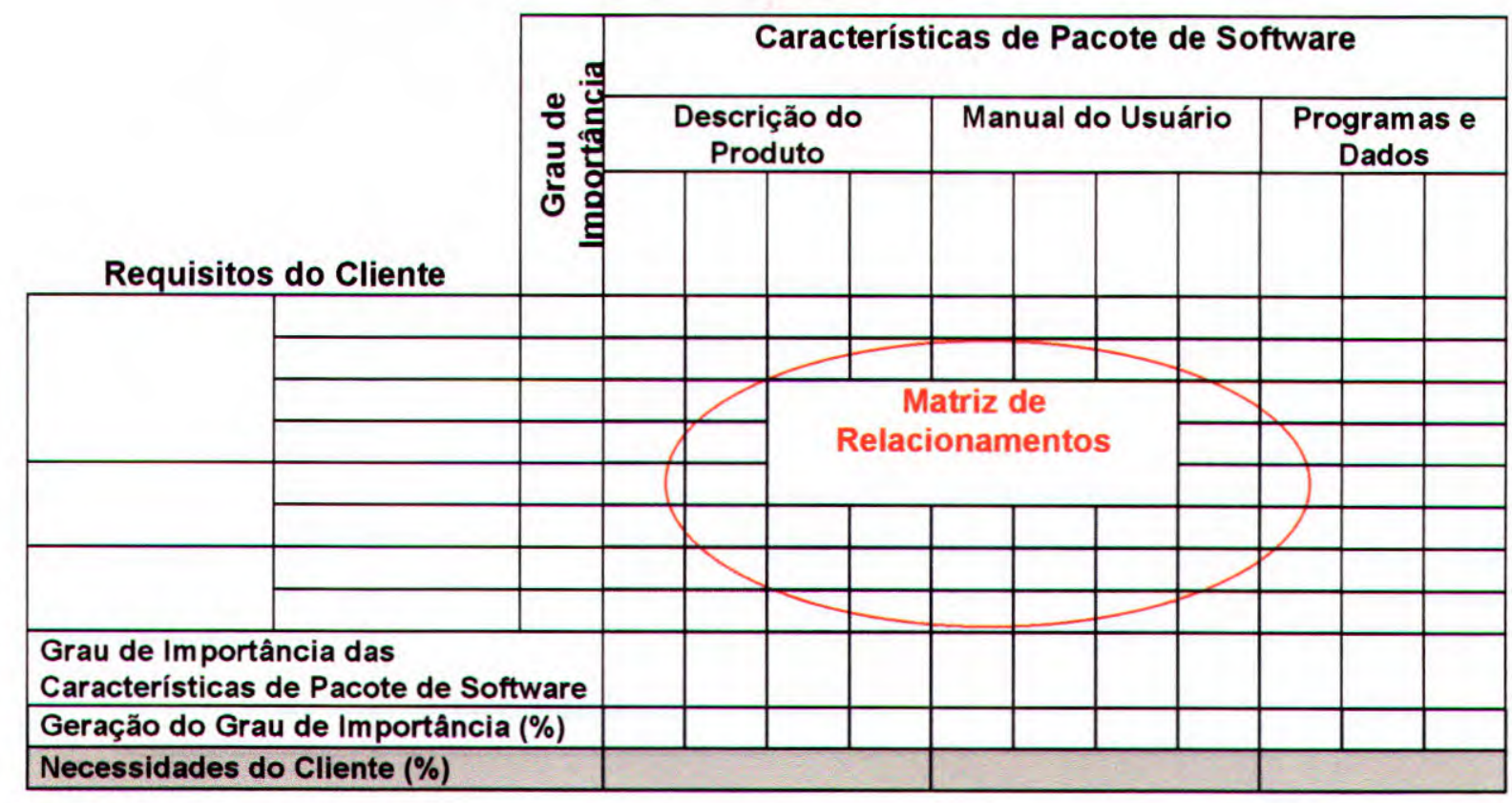

Figura 5.7 - Partes da matriz Casa da Qualidade - Matriz de Relacionamentos

\section{- Geração do Grau de Importância das Características de Pacote}

Após ter correlacionado os requisitos do cliente com as características de pacote de software, gera-se o grau de importância das características de pacote de software. (Figura 5.8). Para isso, deve-se multiplicar o valor de cada correlação pelo respectivo grau de importância do requisito de cliente. Anotar o resultado no canto inferior de cada célula da matriz Casa da Qualidade. Em seguida, determina-se o grau de importância de cada característica de pacote (antepenúltima linha da matriz), somando-se os valores obtidos em cada coluna e colocando o resultado final dessa soma na célula correspondente.

A geração do grau de importância das características de pacote (penúltima linha da matriz) pode então ser obtida, convertendo-se os valores do grau de importância em valores percentuais. Para isso, deve-se dividir o valor de cada coluna pelo somatório da linha de "grau de importância das características de pacote de software".

Finalmente, deve-se somar os valores obtidos na penúltima linha da matriz da Figura 5.8 para cada uma das características de pacote de software (descrição do produto, manual do usuário e programas e dados) e transcrever os resultados para as células correspondentes da última linha da matriz. 


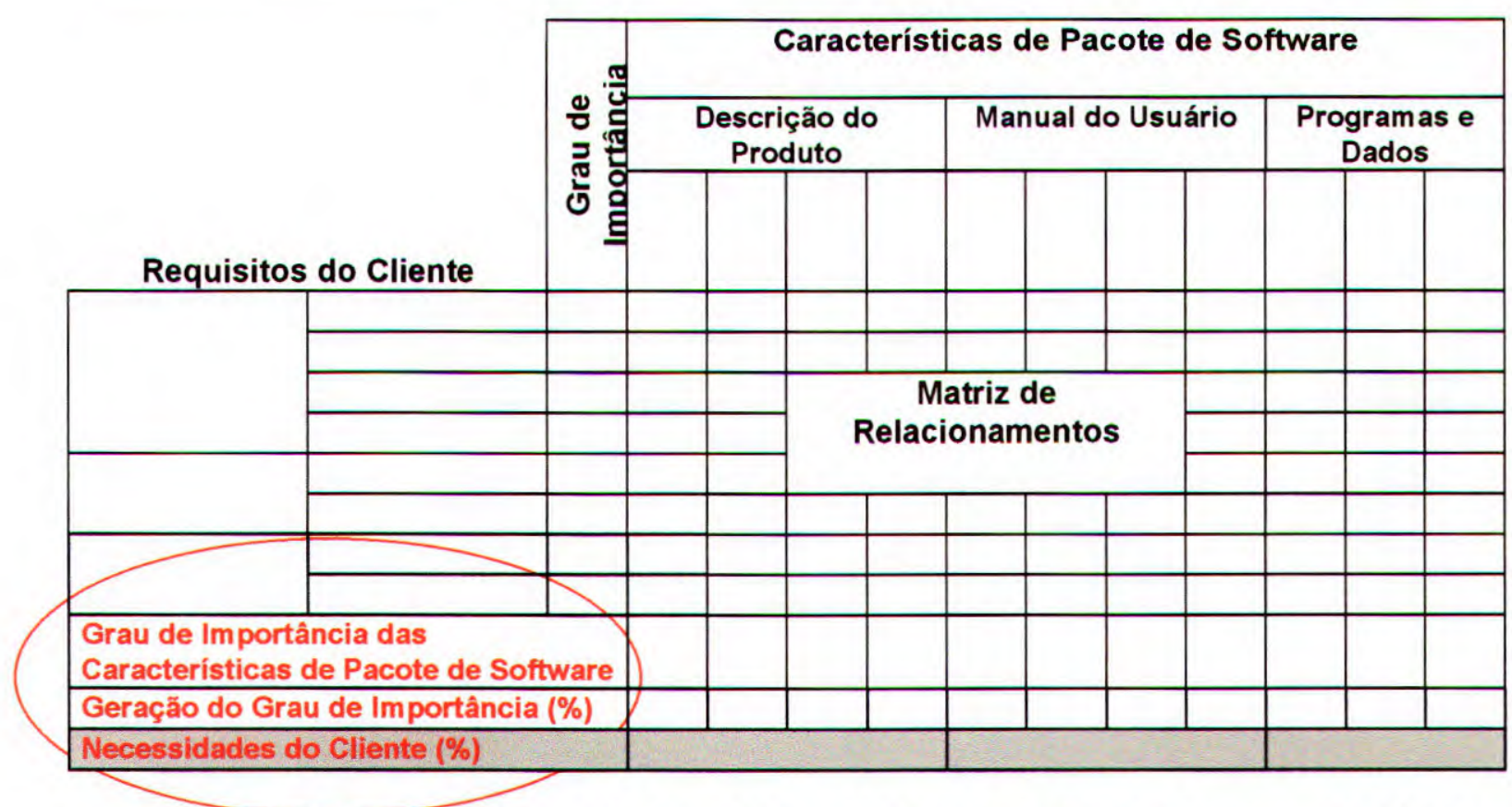

Figura 5.8 - Partes da matriz Casa da Qualidade - Geração do Grau de Importância

Exemplos de utilização da estratégia são apresentados em dois estudos de caso no Capítulo 7.

\section{4 - Considerações Finais}

Neste capítulo foi apresentada as quatro etapas para gerar a matriz Casa da Qualidade. Para auxiliar a primeira etapa (requisitos do cliente e grau de importância), instanciou-se o processo IPAIA para o domínio QFD - Casa da Qualidade. Também foi apresentada a estratégia para elaboração da matriz Casa da Qualidade.

No próximo capítulo é apresentado um procedimento para escolha de pacote de software na área de Sistemas de Informação que inclui as informações sobre necessidades do cliente produzidas pela matriz Casa da Qualidade. 


\section{CAPÍTULO 6 - UM PROCEDIMENTO PARA ESCOLHA DE PACOTE DE SOFTWARE}

\section{1 - Considerações Iniciais}

Este capitulo apresenta um procedimento para escolha de pacote de software na área de Sistemas de Informação o qual permite que a qualidade de pacote de software seja avaliada. Nesse procedimento estão descritos os principais estágios, que são: definição de requisitos, preparação e avaliação. No contexto deste trabalho, esse procedimento irá auxiliar na obtenção de uma nota (valor) para o pacote de software avaliado.

\section{2 - Introdução}

Para realizar a avaliação de qualidade de pacote de software é necessário um modelo de processo de avaliação. O modelo utilizado neste trabalho é o apresentado na norma NBR ISO/IEC 9126. O modelo que está nessa norma (Figura 6.1) é genérico e pode ser usado para qualquer pacote de software. Os principais estágios do modelo são: definição de requisitos, preparação e avallação [NBR ISO/IEC 9126, 1994]. 


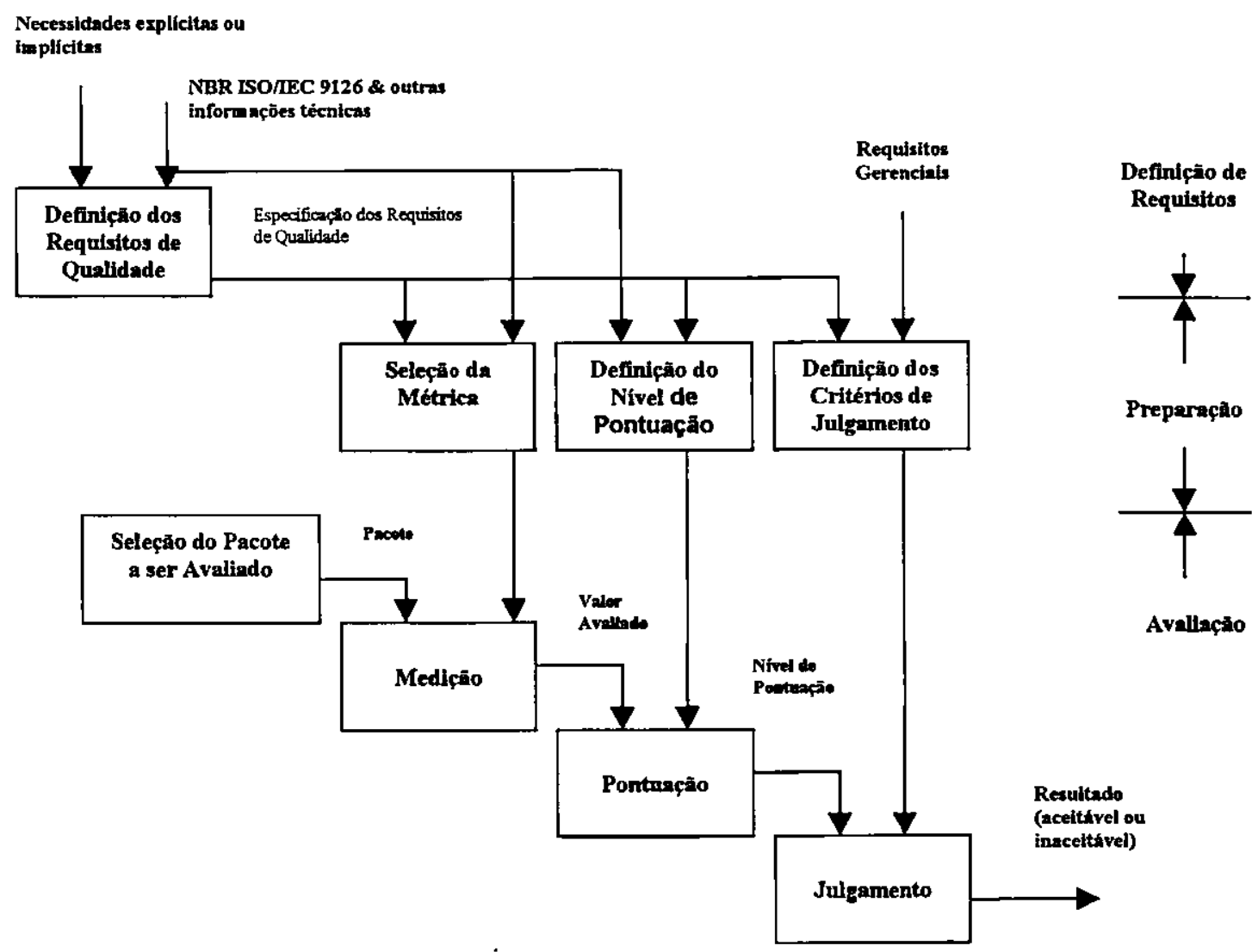

Figura 6.1 - Modelo de Processo de Avaliação adaptado da norma [NBR ISO/IEC 9126, 1994]

\section{3 - Definição de Requisitos de Qualidade de Pacote de Software}

O objetivo do primeiro estágio do modelo é especificar os requisitos do pacote em termos de características de qualidade e possíveis subcaracterísticas.

Os requisitos expressam as exigências do ambiente pelo pacote de software em consideração, e precisam ser definidos antes da avaliação.

À medida que um pacote de software é decomposto em seus componentes principais, os requisitos derivados do pacote como um todo podem ser diferentes para cada componente.

Os requisitos e as características de qualidade para pacote de software considerados neste trabalho são os apresentados na norma NBR 12119 (Quadro 6.1). 
Quadro 6.1 - Requisitos de Qualidade de Pacote de Software

\begin{tabular}{|c|c|}
\hline Requisitos de Qualidade de Pacote & Características de Qualidade \\
\hline \multirow[t]{9}{*}{ Descrição do Produto } & $\begin{array}{l}\text { Requisitos Gerais sobre o Conteúdo da Descriçăo do } \\
\text { Produto }\end{array}$ \\
\hline & Identificaçăo \\
\hline & \begin{tabular}{|l} 
Indicaçăo \\
\end{tabular} \\
\hline & \begin{tabular}{|l|} 
Declaração sobre Funcionalidade \\
\end{tabular} \\
\hline & Declaração sobre Confiabilidade \\
\hline & Declaração sobre Usabilidade \\
\hline & Declaração sobre Eficiência \\
\hline & Declaração sobre Manutenibilidade \\
\hline & Declaração sobre Portabilidade \\
\hline \multirow[t]{5}{*}{ Manual do Usuário } & Completitude \\
\hline & Correçáo \\
\hline & Consistência \\
\hline & Inteligibilidade \\
\hline & Apresentaçăo e Organizaçāo \\
\hline \multirow[t]{6}{*}{ Programas e Dados } & Funcionalidade \\
\hline & Confiabilidade \\
\hline & Usabilidade \\
\hline & Eficiència \\
\hline & Manutenibilidade \\
\hline & Portabilidade \\
\hline
\end{tabular}

\section{4 - Preparação da Avaliação de Pacote de Software}

O objetivo do segundo estágio do modelo é preparar as bases para a avaliação, ou seja, realizar a seleção de métricas, definir o nivel de pontuação e definir os critérios de julgamento do pacote de software.

\subsection{1 - Seleção de Métricas de Qualidade}

A maneira como as características de qualidade são definidas não permite sua medição direta. Portanto, existe a necessidade de estabelecer métricas correlacionadas às características do pacote de software, uma vez que não existe um método formal simples ou uma técnica para especificar métricas. A especificação das métricas não é uma tarefa trivial. A eficiência de uma métrica, ou seja, a importância dos resultados tem um certo custo e é um parâmetro importante na escolha.

As métricas foram criadas considerando-se particularidades relacionadas ao ambiente. Essas métricas são qualitativas, estão apresentadas na primeira coluna dos Quadros 6.2, 6.3 e 6.4 e foram baseadas nas declarações sobre os fatores de qualidade descritos na norma NBR 12119. 


\subsection{2 - Definição dos Níveis de Pontuação}

Cada particularidade utilizada para medir as características de qualidade são pontuadas em três niveis:

0 - nivel de pontuação pobre

1 - nivel de pontuação satisfatório

2 - nivel de pontuação excelente

Pode-se utilizar apenas dois níveis de pontuação como resposta para cada particularidade, tais como Não e Sim, representados através dos valores 0 e 2 respectivamente; Também é possivel utilizar os três níveis citados acima, tendo como exemplo de respostas: 0 - Não, 1 - Algumas informações, e, 2 - Todas as informações.

Os niveis de pontuação de cada particularidade são apresentados na segunda coluna dos Quadros 6.2, 6.3 e 6.4 .

O procedimento para sintetizar as respostas contidas nos Quadros 6.2, 6.3 e 6.4 envolve três etapas:

Primeira etapa: somar as notas das características de qualidade para obter a nota do requisito de qualidade. O valor obtido é colocado no campo nota da primeira linha do quadro de métricas correspondente ao requisito de qualidade.

Segunda etapa: contar a quantidade de métricas que existem para cada requisito de qualidade, e multiplicar essa quantidade pela nota máxima que é dois (2), para obter a nota máxima do requisito de qualidade. O valor obtido é colocado no campo nota máxima da primeira linha do quadro de métricas correspondente ao requisito de qualidade.

Terceira etapa: converter a nota do requisito de qualidade em valor percentual. Para isso, deve-se dividir o valor da nota pela nota máxima e multiplicar por 100 . O valor obtido é colocado no campo resultado(\%) da primeira linha do quadro de métricas correspondente ao requisito de qualidade.

O Quadro 6.5 mostra uma exemplificaçāo de como sintetizar o procedimento descrito acima. Os valores obtidos na primeira linha desse quadro estão descritos a seguir:

- Somando-se as notas obtidas nas doze (12) respostas, obtém-se o valor dezesseis (16) para a nota do requisito de qualidade manual do usuário.

- Multiplicando o valor dois (2) pela quantidade de métricas existentes para o requisito de qualidade manual do usuário, que são doze (12), obtém-se o valor 24 para a nota máxima. 
- Dividindo o valor 16 do campo nota pela nota máxima, que é 24 , multiplicado por 100 , obtém-se o resultado 66,66 .

Quadro 6.2 - Métricas para Mediçāo de Pacote de Software - Descriçāo do Produto

\begin{tabular}{|c|c|}
\hline $\begin{array}{l}\text { MÉTRICAS PARA DESCRIÇÁO DO PRODUTO } \\
\text { Nota }=\end{array}$ & Nota Máxima = \\
\hline MEDIDAS & RESPOSTAS \\
\hline \multicolumn{2}{|c|}{ Característica de Qualidade: Requisitos Gerais sobre o conteúdo da descriçăo do produto } \\
\hline $\begin{array}{l}\text { 1. O conteúdo da descriçāo do produto está inteligívei, compieto e } \\
\text { possui boa organizaçāo e apresentação? }\end{array}$ & $\begin{array}{l}\text { N. Não. A descrição está muito técnica } \\
\text { 1. Algumas partes estão dificeis de compreender } \\
\text { 2. Sim. Geralmente } \\
\end{array}$ \\
\hline
\end{tabular}

Caracteristica de Qualidade: Identificaçăo

2. O documento da descrição do produto possul uma única 0 . Nāo identificação?

\begin{tabular}{ll|l}
\hline 3. A identificaçāo do produto possui o nome do produto e uma versão & 0. Não
\end{tabular} ou data?

2. Sim

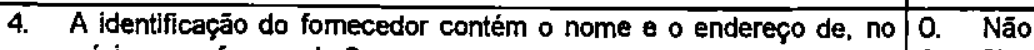
minimo, um fomecedor?

2. Sim

\begin{tabular}{lll|ll}
\hline 5. & Existe indicação das tarefas que podem ser realizadas utilizando o & 0. & Não
\end{tabular} produto?

2. $\operatorname{Sim}$

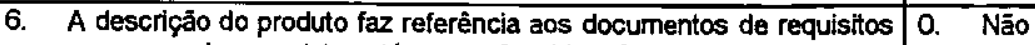
\begin{tabular}{l|ll} 
com os quais o produto está em conformidade? & 1. & Faz \\
& 2. & Sim
\end{tabular}

Característica de Qualidade: Indlcaçäo

\begin{tabular}{lll|ll}
\hline 7. Existe Indicação dos requisitos de hardware e software para colocar & 0. & Não
\end{tabular} o produto em uso, ou seja, nomes de fabricantes e identificação do 1 . Alguns requisitos estāo identificados, nảo todos tipo de todos os componentes?

2. Sim. Todos os requisitos estão identificados

\begin{tabular}{ll|ll} 
8. Se a descriçāo do produto faz referências a interfaces com outros & 0. & Não
\end{tabular} \begin{tabular}{l|l} 
produtos, essas intertaces ou produtos estäo identificados? & $1 . \quad$ Aigumas interfaces ou produtos estão
\end{tabular}

identificados

2. Sim. Todas as interfaces ou produtos estâo identificados

9. Todo componente físico do produto fornecldo está identificado, 0 . Nāo inciuindo todos os documentos impressos e todos os meios de 1. Alguns componentes físicos estão identificados armazenamento?

2. Sim. Todos os componentes fisicos eståo identificados

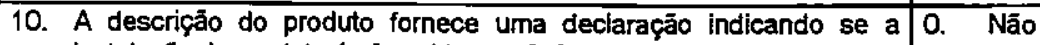
instaiaçäo do produto é oferecida ou nảo?

2. Sim

11. A descriçåo do produto fomece uma declaraçāo indicando se a manutenç̧āo do produto é oferecida ou não?

2. $\operatorname{Sim}$

Característica de Qualidade: Declaraçāo sobre Funcionalidade

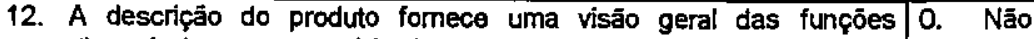
disponiveis para o usuário do produto, os dados necessários e as 1. Apresenta algumas funçỏes disponiveis, não facilidades oferecidas?

13. Os valores limite são especificados para todos os dados de entrada 0. Não que deverāo ser testados?

2. Sim. Apresenta todas as funçöes disponiveis

\begin{tabular}{|l|ll} 
& 2. & Sim. Apresenta todos os valores limite \\
\hline 14. A descrição do produto inclú informaçōes a respeito de maneiras, se & 0. & Năo \\
fomecidas, para evitar o acesso não autorizado (acidental ou & 1. Apresenta algumas informaçōes \\
intencional) a programas e dados? & 2 . Sim. Apresenta todas as informaçöes \\
\hline
\end{tabular}


Quadro 6.2 - Métricas para Medição de Pacote de Software - Descrição do Produto (continuação)

\begin{tabular}{|c|c|}
\hline \multicolumn{2}{|l|}{ MÉTRICAS PARA DESCRIÇĀO DO PRODUTO } \\
\hline MEDIDAS & RESPOSTAS \\
\hline \multicolumn{2}{|l|}{ Característica de Qualidade: Declaração sobro Confiabilidado } \\
\hline $\begin{array}{l}\text { 15. Existe uma declaraçáo dlzendo como se deve fazer backup } \\
\text { (através do Sistema Operacional ou de um comando específico } \\
\text { contido no software produto)? }\end{array}$ & $\begin{array}{ll}\text { O. } & \text { Não } \\
\text { 2. } & \text { Sim }\end{array}$ \\
\hline $\begin{array}{l}\text { 16. É possivel reverter funções de efeito drástico decorrentes de erro } \\
\text { de usuário? }\end{array}$ & \begin{tabular}{|ll}
0. & Nǎo \\
1. & As vezes, näo sempre \\
2. & Sim. Geralmente \\
\end{tabular} \\
\hline \multicolumn{2}{|c|}{ Característica de Qualidade: Declaração sobre Usabilidade } \\
\hline $\begin{array}{l}\text { 17. O tipo de interface com o usuário está especificado na descriçăo } \\
\text { do produto, por exemplo, menu, Janelas, teclas de funçáo, funçâo } \\
\text { de help? }\end{array}$ & $\begin{array}{ll}0 . & \text { Não } \\
\text { 1. Alguns tipos de interfaces estăo especiflcados } \\
\text { 2. Slm. Todos os tipos de interfaces estäo } \\
\text { especificados }\end{array}$ \\
\hline $\begin{array}{l}\text { 18. Se é necessário conhecimento específico para a aplicaçāo do } \\
\text { produto, este conhecimento específico exlgido está descrito na } \\
\text { descrição do produto? }\end{array}$ & $\begin{array}{ll}0 . & \text { Nฐ⿱ } \\
2 . & \operatorname{Sim}\end{array}$ \\
\hline $\begin{array}{l}\text { 19. Se o produto pode ser adaptado pelo usuário, entäo as } \\
\text { ferramentas para essa adaptaçäo e as condlçōes para seu uso } \\
\text { estão identificadas? (exemplos: mudança de parâmetros, } \\
\text { mudança de algoritmos para computaçăa e atribuiçăo de teclas } \\
\text { de funçăo). }\end{array}$ & $\begin{array}{ll}\text { 0. Năo } & \\
\text { 1. } & \text { Algumas informaç̋̄es para adaptaçăo estão } \\
\text { identificadas } & \\
\text { 2. Sim. Geraimente }\end{array}$ \\
\hline $\begin{array}{l}\text { 20. Se a proteçāo técnica contra infraçóes a dilreitos autorais pode } \\
\text { dificultar a usabllidade, então essa proteçăo está declarada? } \\
\text { (exemplos: proteção técnica contra cópias, datas programadas } \\
\text { de expiraçăa de uso, lembretes interattvos para pagamento por } \\
\text { cópia) }\end{array}$ & $\begin{array}{ll}\text { 0. } & \text { Năo } \\
\text { 1. } & \text { Algumas Informaçōes estão declaradas } \\
\text { 2. } & \text { Sim. Geralmente }\end{array}$ \\
\hline \multicolumn{2}{|l|}{ Característica de Qualidade: Declareção sobre Eficiéncia } \\
\hline $\begin{array}{l}\text { 21. A descrição do produto possui dados sobre o comportamento do } \\
\text { produto em relação ao tempo, tals como tempo de resposta e de } \\
\text { processamento e a velocidade de execuçäo? }\end{array}$ & $\begin{array}{ll}\text { 0. } & \text { Não } \\
\text { 2. } & \text { Sim }\end{array}$ \\
\hline \multicolumn{2}{|c|}{ Característica de Qualidade: Deciaração sobre Manuteniblifiade } \\
\hline $\begin{array}{l}\text { 22. A descriçăo do produto contém declaraçōes que evidenciam o } \\
\text { esforço necessário para fazer modifflcaçōes especificadas no } \\
\text { software? }\end{array}$ & $\begin{array}{ll}\text { 0. } & \text { Nāo } \\
\text { 2. } & \text { Sim }\end{array}$ \\
\hline \multicolumn{2}{|l|}{ Característica de Qualidade: Deciaração sobre Portabifidade } \\
\hline $\begin{array}{l}\text { 23. A descriçăo do produto contém declaraçöes que evidenciam a } \\
\text { capacidade do software ser transferido de um ambiente para } \\
\text { outro? }\end{array}$ & $\begin{array}{ll}\text { 0. } & \text { Nåo } \\
\text { 2. } & \text { Sim }\end{array}$ \\
\hline
\end{tabular}


Quadro 6.3 - Métricas para Medição de Pacote de Software - Manual do Usuário

\begin{tabular}{|c|c|}
\hline \multicolumn{2}{|l|}{ METRICAS PARA MANUAL DO USUARIO } \\
\hline MEDIDAS & RESPOSTAS \\
\hline \multicolumn{2}{|l|}{ Caracteristica de Qualidade: Completitude } \\
\hline $\begin{array}{l}\text { 1. As informaçôes contidas na descrição do produto também estäo } \\
\text { inciuidas no mariual do usuário? }\end{array}$ & $\begin{array}{|ll|}0 . & \text { Näo } \\
1 . & \text { Algumas informaçöes } \\
\text { 2. } & \text { Sim } \\
\end{array}$ \\
\hline $\begin{array}{l}\text { 2. As informaçōes ausentes (que estão faltando) estão ciaramente } \\
\text { identificadas na norma com reiaçăo a quando ou como a informação } \\
\text { tomar-se-á disponivel e será incluída no manual do usuário? }\end{array}$ & $\begin{array}{l}\text { 0. Näo, a informação ausente cuja ausência é } \\
\text { óbvia, não está disponivei } \\
\text { 1. A informação ausente é fundamental identificà-la } \\
\text { 2. Sim - a informação da informação ausente é } \\
\text { satisfatória ou aparentemente nenhuma } \\
\text { informação está faltando }\end{array}$ \\
\hline $\begin{array}{l}\text { 3. O manual do usuário possui exemplos de telas (menus, etc) que } \\
\text { poderiam ser encontradas durante a execução do software? }\end{array}$ & $\begin{array}{l}\text { 0. Năo. Somente figuras das telas principais são } \\
\text { mostradas } \\
\text { 1. Figuras de telas, menus, etc, sảo mostrados } \\
\text { mas seus conteúdos não são mostrados } \\
\text { 2. Sim - o número e a qualidade das figuras de } \\
\text { teias no manual do usuário são satisfatórios }\end{array}$ \\
\hline \multicolumn{2}{|l|}{ Característica de Qualidade: Correção } \\
\hline $\begin{array}{l}\text { 4. As informaçöes contidas no manuai do usuário estäo corretas, ou } \\
\text { seja, sem ambigüidades e erros? }\end{array}$ & $\begin{array}{|ll|}0 . & \text { Năo } \\
\text { 1. } & \text { Aigumas informaçōes estäo ambiguas } \\
\text { 2. } & \text { Sim, todas } \\
\end{array}$ \\
\hline \multicolumn{2}{|l|}{ Característica de Qualidade: Consistencia } \\
\hline $\begin{array}{l}\text { 5. Os documentos do manual do usuário näo apresentam contradiçöes } \\
\text { entre sí e com a descrição do produto? }\end{array}$ & $\begin{array}{l}\text { 0. Quase sempre apreseritam contradiçöes } \\
\text { 1. Usuaimente, mas não sempre } \\
\text { 2. Geralmerite não apresentam contradiçőes }\end{array}$ \\
\hline $\begin{array}{l}\text { 6. A tabela do conteúdo está consistente com o conteúdo do manual } \\
\text { com respeito à paginação, títulos e numeração? }\end{array}$ & $\begin{array}{l}\text { 0. Não ou nenhuma tabeia de conteúdo fol } \\
\text { encontrada } \\
\text { 1. Menos do que } 5 \text { inconsistências foram } \\
\text { encontradas } \\
\text { 2. Sim } \\
\end{array}$ \\
\hline $\begin{array}{l}\text { 7. Quando a diretriz (norma) no manual do usuário, descreve funçōes } \\
\text { especificas do software, são observadas se a funçäa executa como o } \\
\text { esperado (ou seja, as conseqũências da execução da funçäo, de } \\
\text { fato, são como as descritas no manuai do usuário)? }\end{array}$ & $\begin{array}{ll}\text { 0. } & \text { Não } \\
\text { 1. } & \text { Algumas funçōes executam como o esperado } \\
\text { 2. Sim, todas as furç̧̄es executam como o } \\
\text { esperado }\end{array}$ \\
\hline 8. Os termos definidos estāo explicados consistentemente? & $\begin{array}{ll}0 . & \text { Näo, geraimente não } \\
\text { 1. } & \text { Usualmente, mas näo sempre } \\
\text { 2. } & \text { Sim, sempre } \\
\end{array}$ \\
\hline \multicolumn{2}{|l|}{ Característica de Qualidade: Inteligibilidade } \\
\hline $\begin{array}{l}\text { 9. O manual do usuário está bem escrito e de fácil entendimento para } \\
\text { um leitor sem nenhum conhecimento (background) do sistema? }\end{array}$ & $\begin{array}{l}\text { 0. Não. O manual está muito técnico } \\
\text { 1. } \text { Algumas partes estão dificeis de compreender } \\
\text { 2. Sim, geralmente }\end{array}$ \\
\hline \multicolumn{2}{|l|}{ Característica de Qualidade: Apresentação e Organização } \\
\hline $\begin{array}{l}\text { 10. O manual do usuário inclui uma lista de referências para outros } \\
\text { documentos importantes com reiação ao sistema atual? }\end{array}$ & $\begin{array}{l}\text { 0. Não } \\
\text { 1. A lista de referéncia está desestruturada / } \\
\text { incompieta / dificli para usar } \\
\text { 2. Sim, a lista de referéncia está suficientemente } \\
\text { compieta e proveitosa ou aparentemente, outros } \\
\text { documentos não são essenciais para o } \\
\text { entendimento do usuário com reiaģa ao } \\
\text { sistema }\end{array}$ \\
\hline $\begin{array}{l}\text { 11. As definiçōes dos termos estão repetidos toda a vez que eies são } \\
\text { encontrados no texto ou essas definiçōes estāo inciuidas nas } \\
\text { referéncias? }\end{array}$ & $\begin{array}{l}\text { 0. Multas repetiçōes ou nenhuma defin|çẫo foi } \\
\text { encontrada } \\
\text { 1. Algumas repetiçőes } \\
\text { 2. Referências para definiçőes únicas } \\
\end{array}$ \\
\hline $\begin{array}{l}\text { 12. O manual do usuário contém figuras, tabelas, etc, para expilcar } \\
\text { meihor o conteúdo num grau satisfatório (aceitávei)? }\end{array}$ & $\begin{array}{ll}0 . & \text { Nāo } \\
1 . & \text { Figuras, etc, săo usadas raramente } \\
2 . & \text { Figuras, etc, săo usadas extensivamente }\end{array}$ \\
\hline
\end{tabular}


Quadro 6.4 - Métricas para Medição de Pacote de Software - Programas e Dados

\begin{tabular}{|c|c|}
\hline METRICAS PARA PROGRAMAS E DADOS & Nota Máxima $=$ \\
\hline MEDIDAS & RESPOSTAS \\
\hline \multicolumn{2}{|l|}{ Característica de Qualidade: Funcionalidade } \\
\hline $\begin{array}{l}\text { 1. Existe um manual de instalaçăo com instruçōes detaihadas para } \\
\text { o usuário realizar a instalaçăo dos programas? }\end{array}$ & $\begin{array}{l}\text { Não } \\
\text { 2. Sim - ou aparentemente, a instalaçăo dos programas } \\
\text { não é realizada pelo próprio usuário }\end{array}$ \\
\hline $\begin{array}{l}\text { 2. É possivel instalar os programas seguindo as infornaçőes } \\
\text { contidas no manuai de instalaçăo? }\end{array}$ & $\begin{array}{l}\text { 0. Nāo } \\
\text { 2. Sim - ou aparentemente, a instalaçáo dos programas } \\
\text { não é realizada peio próprio usuário }\end{array}$ \\
\hline $\begin{array}{l}\text { 3. É possívei verificar se uma instaiaçăo dos programas foi bem } \\
\text { sucedida? }\end{array}$ & $\begin{array}{l}\text { Nâo } \\
\text { 2. Sim - ou aparentemente, a instalação dos programas } \\
\text { não é reailzada peio próprio usuário }\end{array}$ \\
\hline $\begin{array}{l}\text { 4. O controle da operação e do comportamento do programa pelo } \\
\text { usuário, por exempio, mensagens, formatos de tela de entrada e } \\
\text { relatórios impressos estäo estruturados de maneira uniforme? }\end{array}$ & $\begin{array}{ll}\text {. Não } \\
\text { 1. Aigumas informaçōes estāo estruturadas } \\
\text { 2. Sim, todas }\end{array}$ \\
\hline $\begin{array}{l}\text { 5. Existe consistência de vocabuiário entre as mensagens dos } \\
\text { programas e a documentaçăo? }\end{array}$ & $\begin{array}{ll}0 . & \text { N5a } \\
\text { 2. } & \text { Sim }\end{array}$ \\
\hline \multicolumn{2}{|l|}{ Característica de Qualidade: Confiabilldade } \\
\hline $\begin{array}{l}\text { 6. Se os dados estiverem fora dos ilimites especificados, o usuário } \\
\text { conseguirá controiar esse estado anormai sern perder dados? }\end{array}$ & $\begin{array}{ll}\text { O. } & \text { Nāo } \\
\text { 2. } & \text { Sim }\end{array}$ \\
\hline \multicolumn{2}{|l|}{ Característica de Qualidade: Usabilidade } \\
\hline $\begin{array}{l}\text { 7. As mensagens de erro apresentam informaçbes necessárias } \\
\text { para a soiuçăo da situaçăo de erro (por exemplo, uma referência } \\
\text { a um Htem no manuai do usuário)? }\end{array}$ & $\begin{array}{ll}\text { O. } & \text { Nāo } \\
\text { 2. } & \text { Sim }\end{array}$ \\
\hline $\begin{array}{l}\text { 8. Existe identificaçäo da funçăo do programa que está sendo } \\
\text { executada no momento? }\end{array}$ & $\begin{array}{ll}\text { O. Năo } \\
\text { 1. Aiguns programas exibem a identificaçăo da funçăo } \\
\text { que está sendo executada } \\
\text { 2. Sim }\end{array}$ \\
\hline $\begin{array}{l}\text { 9. As mensagens dos programas foram projetadas de foma que o } \\
\text { usuário possa diferenciá-las pelo tipo (por exempio, mensagens } \\
\text { de confimaçăo, consulta, advertência e erro)? }\end{array}$ & $\begin{array}{ll}0 . & \text { Năo } \\
\text { 2. } & \text { Sim }\end{array}$ \\
\hline 10. Existe ciareza nos formatos de telas de entrada e reiatórios? & $\begin{array}{ll}\text { 0. } & \text { Năo } \\
\text { 2. } & \text { Sim }\end{array}$ \\
\hline $\begin{array}{l}\text { 11. Na execuçăo de funçōes como apagar dados ou sobrepôtos, } \\
\text { existe alertas ciaros para as consequências de uma determinada } \\
\text { confirmação? }\end{array}$ & $\begin{array}{ll}\text { 0. } & \text { Nāo } \\
\text { 2. } & \text { Sim }\end{array}$ \\
\hline $\begin{array}{l}\text { 12. Pode-se interromper um processamento demorado sem ter } \\
\text { consequéncias graves? }\end{array}$ & $\begin{array}{ll}\text { 0. } & \text { Nåo } \\
\text { 2. } & \text { Sim }\end{array}$ \\
\hline \multicolumn{2}{|l|}{ Caracteristica de Quaiidade: Auxllio (he/p) } \\
\hline $\begin{array}{l}\text { 13. Está disponivel atendimento on-line em caso de dúvida a respetto } \\
\text { do software produto? }\end{array}$ & $\begin{array}{ll}\text { O. } & \text { Nāo } \\
\text { 2. } & \text { Sim }\end{array}$ \\
\hline
\end{tabular}


Quadro 6.5 - Exemplos de Métricas para Medição de Pacote de Software

\begin{tabular}{|c|c|}
\hline $\begin{array}{l}\text { MÉTRICAS PARA MANUAL DO USUÁRIO } \\
\qquad \text { Nota }=16 \\
\end{array}$ & Rosultado(\%) $=66,66$ \\
\hline MEDIDAS & RESPOSTAS \\
\hline \multicolumn{2}{|l|}{ Característica de Qualidade: Completitude } \\
\hline $\begin{array}{l}\text { 1. As informaçōes contidas na descriçäo do produto também estão } \\
\text { incluidas no manuai do usuário? }\end{array}$ & \begin{tabular}{|ll}
0. & Não \\
$1 . \checkmark$ & Aigumas informaçōes \\
2. & Sim \\
\end{tabular} \\
\hline $\begin{array}{l}\text { 2. As Informaçóes ausentes (que estāo faltando) estấo ciaramente } \\
\text { identificadas na norma com relaçăo a quando ou como a informação } \\
\text { tomar-se-á disponivei e será inciuída no manuai do usuário? }\end{array}$ & $\begin{array}{l}\text { 0. Não, a informaçâo ausente cuja ausência é óbvia, } \\
\text { não está disponivei } \\
\text { 1. A Informação ausente é fundamental identificá-ia } \\
\text { 2. Sim - a informação da informação ausente é } \\
\text { satisfatória ou aparentemente nenhuma } \\
\text { informaçāo está faltando }\end{array}$ \\
\hline $\begin{array}{l}\text { 3. O manuai do usuário possul exemplos de telas (menus, etc) que } \\
\text { poderiam ser encontradas durante a execuçäo do software? }\end{array}$ & $\begin{array}{l}\text { 0. Não. Somente figuras das telas principais são } \\
\text { mostradas } \\
\text { 1. Figuras de teias, menus, etc, são mostrados } \\
\text { mas seus conteúdos não são mostrados } \\
\text { 2. Sim - o número e a qualidade das figuras de } \\
\text { telas no manuai do usuário são satisfatórios }\end{array}$ \\
\hline \multicolumn{2}{|l|}{ Característica de Qualidade: Correçāo } \\
\hline $\begin{array}{l}\text { 4. As informaçöes contidas no manual do usuário estão corretas, ou } \\
\text { seja, sem ambiguldades e ertos? }\end{array}$ & \begin{tabular}{|l|} 
0. Nāo \\
1. Aigumas informaçōes estāo ambiguas \\
2. Sim, todas \\
\end{tabular} \\
\hline \multicolumn{2}{|l|}{ Característica de Qualidade: Cons/sténcia } \\
\hline $\begin{array}{l}\text { 5. Os documentos do manual do usuárlo riāo apresentam contradlçōes } \\
\text { entre si e com a descriçāo do produto? }\end{array}$ & $\begin{array}{l}\text { O. Quase sempre apresentam contradiçōes } \\
\text { 1.V Usualmente, mas näo sempre } \\
\text { 2. Geralmente nāo apresentam contradiçōes }\end{array}$ \\
\hline $\begin{array}{l}\text { 6. A tabela do conteúdo está consistente com o conteưdo do manual } \\
\text { com respeito à paginaçăo, títuios e numeração? }\end{array}$ & $\begin{array}{l}\text { O. Não ou nentiuma tabela de conteúdo fol } \\
\text { encontrada } \\
\text { 1. Menos do que } 5 \text { inconsistências foram } \\
\text { encontradas } \\
2 . \checkmark \text { Sim } \\
\end{array}$ \\
\hline 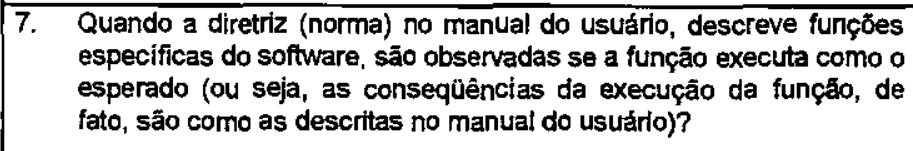 & $\begin{array}{l}\text { Nāo } \\
\text { 1.r Algumas funçöes executam como o esperado } \\
\text { 2. Sim, todas as funçōes executam como o } \\
\text { esperado }\end{array}$ \\
\hline 8. Os termos definidos estão explicados consistentemente? & \begin{tabular}{ll|}
0. & Nâo, geralmente não \\
1. Usualmente, mas não sempre \\
2. S Sim, sempre
\end{tabular} \\
\hline \multicolumn{2}{|l|}{ Característica de Qualidade: Inteligibilldade } \\
\hline $\begin{array}{l}\text { O. O manuai do usuário está bem escrito e de fácil entendimento para } \\
\text { um leitor sem nenhum conhecimento (background) do sistema? }\end{array}$ & $\begin{array}{l}\text { 0. Nâo. O manuai está mujto técnico } \\
\text { 1. Aigumas partes estâo dificeis de compreender } \\
\text { 2. Sim, geralmente }\end{array}$ \\
\hline \multicolumn{2}{|l|}{ Caracteristica de Qualldade: Apresentaça e Organ/zaça } \\
\hline $\begin{array}{l}\text { 10. O manual do usuário inciui uma lista de referênclas para outros } \\
\text { documentos importantes com relação ao sistema atual? }\end{array}$ & 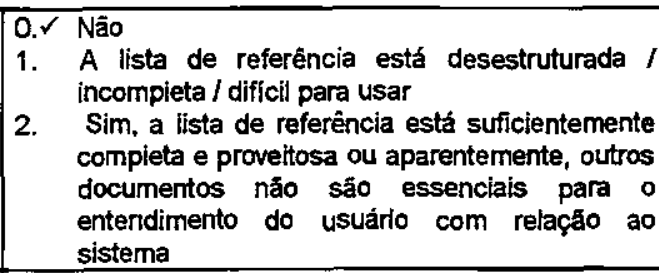 \\
\hline $\begin{array}{l}\text { 11. As definiçōes dos termos estáo repetidos toda a vez que eies sáo } \\
\text { encontrados no texto ou essas definiçōes estāo incluidas nas } \\
\text { referências? }\end{array}$ & $\begin{array}{l}\text { Muitas repetiçóes ou nenhuma definiçăo fol } \\
\text { encontrada } \\
\text { 1. Algumas repetiçöes } \\
\text { 2. Referências para definiçōes únicas } \\
\end{array}$ \\
\hline $\begin{array}{l}\text { 12. O manuai do usuário contém figuras, tabelas, etc, para expilicar } \\
\text { meihor o conteúdo num grau satisfatório (aceitávei)? }\end{array}$ & $\begin{array}{ll}\text { O. Năo } \\
\text { 1. } \\
\text { 2. Figuras, etc, são usadas raramente } \\
\end{array}$ \\
\hline
\end{tabular}




\subsection{3 - Definição dos Critérios de Julgamento}

Para o julgamento do pacote de software é necessáno elaborar um quadro comparativo das necessidades do cliente com relação aos niveis de pontuação obtidos das avaliações dos pacotes (Quadro 6.6). Para isso, deve-se seguir os passos descritos abaixo:

a) Transcrever as necessidades do cliente (obtido em percentual, na última linha da matriz Casa da Qualidade, na seção 5.3 do Capítulo 5), para a segunda coluna do Quadro 6.6;

b) Transcrever o resultado obtido nos Quadros $6.2,6.3$ e 6.4 referente a cada requisito de qualidade para a respectiva coluna "resultado(\%)", correspondente a avaliação do pacote;

c) Multiplicar o valor da segunda coluna pelo valor correspondente da coluna "resultado(\%)" e transcrever o resultado para a respectiva coluna de "proporção", correspondente a avaliação do pacote.

O valor transcrito para a coluna "resultado(\%)" significa quanto das necessidades do cliente com relação a característica de pacote de software foi atendida.

O valor obtido na coluna "proporção" significa a proporcionalidade das necessidades do cliente com relação a caracteństica de pacote de software.

Para obter o valor medido do pacote avaliado, deve-se somar os valores da coluna "proporção", correspondente a avaliação do pacote.

Deve-se repetir os passos dos itens a), b) e c) para todos os pacotes de software a serem avaliados.

Quadro 6.6 - Comparação das Necessidades do Cliente versus Pacotes Avaliados

\begin{tabular}{|c|c|c|c|c|c|}
\hline \multirow{2}{*}{$\begin{array}{c}\text { Características de Qualidade } \\
\text { de Pacote de Software }\end{array}$} & \multirow{2}{*}{$\begin{array}{l}\text { Necessidades do } \\
\text { Cliente }(\%)\end{array}$} & \multicolumn{2}{|c|}{ Avallação do Pacote X } & \multicolumn{2}{|c|}{ Avaliaçāo do Pacote $Y$} \\
\hline & & Resultado(\%) & Proporçāo & $\begin{array}{l}\text { Resultad } \\
o(\%)\end{array}$ & $\begin{array}{l}\text { Proporç } \\
\text { ão }\end{array}$ \\
\hline \multicolumn{6}{|l|}{ Descrição do Produto } \\
\hline \multicolumn{6}{|l|}{ Manual do Usuário } \\
\hline \multicolumn{6}{|l|}{ Programas e Dados } \\
\hline Valor Medido & & 䎿 & & & \\
\hline
\end{tabular}




\section{5 - Procedimento de Avaliação de Pacote de Software}

O último estágio do Modelo de Processo de Avaliação é composto por três passos, que são: medição, pontuação e julgamento.

Para medição, os questionários dos Quadros $6.2,6.3$ e 6.4 são respondidos considerando-se o pacote de software.

No passo referente à pontuação, o nível de pontuação é avaliado considerando-se as respostas dadas nos questionários.

O julgamento é uma decisão do cliente. O pacote de software que estiver com o valor medido mais próximo das necessidades do cliente, é um bom parâmetro para o cliente tomar sua decisão.

\section{6 - Considerações Finais}

Neste capitulo foi apresentado um procedimento para escolha de pacote de software na área de Sistemas de Informação, destacando-se os passos de definição de requisitos, preparação e avaliação.

No próximo capítulo são apresentados dois estudos de caso exemplificando a aplicação desse procedimento. 


\section{CAPÍTULO 7 - ESTUDOS DE CASO DA UTILIZAÇÃO DO PROCEDIMENTO PARA ESCOLHA DE PACOTE DE SOFTWARE}

\section{1 - Consideraçōes Iniciais}

Neste capítulo são relatados dois estudos de caso exemplificando a utilização do procedimento para escolha de pacote de software na área de Sistemas de Informação.

Os estudos de caso são relatados apresentando primeiramente a elaboração da matriz Casa da Qualidade para identificação das necessidades do cliente, e, posteriormente, é apresentada a avaliação do pacote de software.

Nesses estudos de caso foi avaliado apenas um pacote de software para cada aplicação, visto que nas organizações pesquisadas a compra já tinha sido realizada.

\section{2 - Caso 1 - Cantina Famiglia Dall'Agnol}

A Cantina Famiglia Dall'Agnol é um estabelecimento comercial de pequeno porte localizado na cidade de Concórdia, no meio-oeste de Santa Catarina, cuja especialidade é elaborar e servir a culinária típica italiana. 
Esse estabelecimento tem interesse em adquirir um pacote de software que atenda as suas necessidades no que se refere ao atendimento de cantinas ou restaurantes.

\subsection{1 - Elaboração da Matriz Casa da Qualidade}

Para auxiliar a primeira etapa, foi utilizado o processo de aquisição de conhecimento IPAIA, instanciado para o domínio QFD - Casa da Qualidade.

\section{- Início do Processo de Aquisição de Conhecimento}

A área de aplicação do Pacote a ser adquirido refere-se a um sistema de controle do atendimento de cantinas ou restaurantes. O patrocinador foi o próprio dono da Cantina, o Sr. Darlan Dall'Agnol. Os potenciais membros da sessāo de aquisição de conhecimento foram o proprietário, no papel do especialista de dominio e a própria autora deste trabalho de mestrado, no papel de engenheiro de conhecimento e anotador. O estímulo para a aplicação do processo foi realizado através de uma conversa inicial focalizando o que é aquisição de conhecimento, sua importância para a organização, os principais conceitos relacionados à aquisição de conhecimento como especialistas de dominio, engenheiro de conhecimento, entre outros.

Neste estudo de caso, para a obtenção das necessidades do cliente, foi necessária uma única aplicação, tanto do primeiro ciclo quanto do segundo ciclo do processo.

\section{- Ciclo de Visão Geral das Principais Necessidades do Pacote}

Para auxiliar a condução da sessāo de brainstorming, realizada com o proprietário da cantina, elaborou-se um plano (Quadro 7.1), o qual foi entregue ao mesmo com quatro dias de antecedència. 
Quadro 7.1 - Plano para a Sessão de Brainstorming - Cantina

\section{PLANO PARA A SESSÃO DE BRAINSTORMING ESTRUTURADO}

1 Introdução: o objetivo deste plano é orientar o Engenheiro de Conhecimento a conduzir uma sessão de brainstorming estruturado (técnica utilizada para adquirir informações de um grupo de pessaas sabre as suas necessidades quanta a aquisiçãa de um Pacote para o Controle e Automação de Restaurantes).

\section{Gerenciamento}

Local da Sessão: Cantina Famiglia Dall' Agnol

Data da Sessão: 03/02/2000 Horário: 14:30

Tempo Total: 00:45

Engenheiro de Conhecimento: Jusane Farina Lara

Anotador/Assistente: Jusane Farina Lara

Especialista do Domínio/Fonte de Conhecimento: Darlan Dall' Agnal

Cliente: Darlan Dall' Agnol

Meto da Sessão: adquirir uma visão geral do Sistema de Cantrole de Restaurantes a ser adquirido e uma visão detalhada das características desse Pacote.

\section{Tarefas:}

3.1 Iniciaçãa: $O$ abjetiva dessa sessão de brainstorming está facado na abtenção de informações a respeita das requisitos desejáveis em um Pacote de Software para Cantrole de Restaurantes.

3.2 O engenheiro de conhecimento deve introduzir cada uma das funcionalidades cansideradas na listagem de idéias.

3.3 Haverá um tempo dispanível para que a participante exponha a que conhece a respeita das funcionalidades que o sistema deverá ter, termas relacionadas a essas funcionalidades e características gerais que 0 mesma gostaria que 0 pacote farnecesse. $O$ engenheira de canhecimento pade introduzir outras características que podem ser interessantes ao pacote.

3.4O anotadar deve registrar as tare fas na coluna "Dados Originais" da Tabela 7.1:

3.5 Repetir as tarefas 3.2, 3.3 e 3.4 até que tadas as funcianalidades identificadas tenham sida discutidas:

3.6 Converter as Dados Originais para Requisitos do Cliente:

4 Cronograma:

\begin{tabular}{|l|l|l|l|l|l|}
\hline Tarefas & 5 minutas & 15 minutos & 30 minutas & 45 minutas & 60 minutos \\
\hline 3.1 & & & & & \\
\hline 3.2 & & & & & \\
\hline 3.3 & & & & & \\
\hline 3.4 & & & & & \\
\hline 3.5 & & & & & \\
\hline 3.6 & & & & & \\
\hline
\end{tabular}

5 Recursos: no local onde acorrerá a sessão, as membros paderão utilizar uma mesa com cadeiras, para que os mesmos se vejam, e o anotador deverá ter papel e caneta para anotaçães. 
O plano foi colocado em prática; não houve necessidade do papel de moderador, visto o número pequeno de participantes da sessāo de brainstorming, e as idéias foram registradas pelo anotador na coluna "Dados Originais" da Tabela 7.1. Após ter identificado todas as funcionalidades desejáveis do pacote, foi realizada a conversão desses dados originais para requisitos do cliente, completando a Tabela 7.1 . Na seqüência, foi realizada a seleção dos requisitos do cliente entre aqueles que se referem as reais necessidades do pacote. A partir dos requisitos do cliente selecionados, foi elaborada a tabela de desdobramento dos requisitos do cliente (Tabela 7.2) preenchendo-se apenas as duas primeiras colunas.

O conhecimento adquirido foi validado junto ao especialista de domínio e o engenheiro de conhecimento. Para isso, realizou-se uma inspeção para averiguar tanto a consistência quanto a completitude do conhecimento conceitual do domínio adquirido. Depois de realizada a inspeção notou-se que não haveria necessidade de ser realizado outro ciclo brainstoming; desse modo, o ciclo seguinte (de determinação de importáncia das características do pacote) foi realizado visando a obtençāo do grau de importância para cada característica obtida no primeiro ciclo. 
Tabela 7.1 - Obtenção dos Dados Originais - Cantina

\begin{tabular}{|c|c|c|c|}
\hline $\mathbf{N}^{\circ}$ & DADOS ORIGINAIS & $\begin{array}{c}\text { DESDOBRAMENTO DA CENA } \\
\text { (quem, onde, quando, como, } \\
\text { por que) }\end{array}$ & REQUISITO DO CLIENTE \\
\hline \multirow[t]{3}{*}{1} & \multirow{3}{*}{$\begin{array}{l}\text { Fácil de ler e entender as } \\
\text { informaçōes }\end{array}$} & \multirow[t]{3}{*}{ Descritas na caixa do pacote } & Fácil de ler \\
\hline & & & Fácil de entender \\
\hline & & & Boa aparência aos olhos \\
\hline 2 & Pacote deve ter urn único título & Pacote & Fácil de identificar \\
\hline 3 & $\begin{array}{l}\text { Apresentar descriçăo do nome, da } \\
\text { versão ou data }\end{array}$ & Pacote & $\begin{array}{l}\text { Ter conhecimento do nome, da } \\
\text { versảo ou data }\end{array}$ \\
\hline 4 & $\begin{array}{l}\text { Apresentar informaçóes do } \\
\text { fornecedor }\end{array}$ & Pacote & $\begin{array}{l}\text { Ter conhecimento do nome e } \\
\text { endereço do fornecedor }\end{array}$ \\
\hline 5 & $\begin{array}{l}\text { Descrever as principais } \\
\text { caracteristicas }\end{array}$ & Utilização do sisterna & $\begin{array}{l}\text { Fácil de saber quais tarefas são } \\
\text { realizadas }\end{array}$ \\
\hline 6 & $\begin{array}{l}\text { Fazer referência aos documentos } \\
\text { disponiveis }\end{array}$ & Pacote & $\begin{array}{l}\text { Fácil de saber se há referência a } \\
\text { documentos de requisitos }\end{array}$ \\
\hline 7 & $\begin{array}{l}\text { Saber o tipo de computador, } \\
\text { vers5o do windows, quantidade de } \\
\text { memória, espaço ern disco }\end{array}$ & Hardware e software & $\begin{array}{l}\text { Fácil de saber a plataforma } \\
\text { necessária }\end{array}$ \\
\hline 8 & $\begin{array}{l}\text { Permitir integraçăo com Word, } \\
\text { Excel e outros módulos fornecidos } \\
\text { pelo próprio fornecedor }\end{array}$ & Pacote & $\begin{array}{l}\text { Ter possibilidade de integraçöes } \\
\text { com outros produtos }\end{array}$ \\
\hline 9 & $\begin{array}{l}\text { Saber quem fará a instalaçăo dos } \\
\text { prograrnas }\end{array}$ & Pacote & $\begin{array}{l}\text { Ter conhecirnento sobre quem } \\
\text { fará a instalação }\end{array}$ \\
\hline 10 & $\begin{array}{l}\text { Saber se oferece manutençäo ou } \\
\text { náo }\end{array}$ & Pacote & $\begin{array}{l}\text { Ter conhecimento se é oferecida } \\
\text { manutençáo }\end{array}$ \\
\hline 11 & $\begin{array}{l}\text { Possibilidade de ser instalado ern } \\
\text { outro computador }\end{array}$ & Sistema & $\begin{array}{l}\text { Ter conhecimento se pode ser } \\
\text { instalado em outro equipamento }\end{array}$ \\
\hline 12 & $\begin{array}{l}\text { Facilidade de tirar dúvidas por } \\
\text { telefone, internet, etc }\end{array}$ & Uso do Sistema & $\begin{array}{l}\text { Ter conhecimento se é oferecida } \\
\text { assistência }\end{array}$ \\
\hline 13 & $\begin{array}{l}\text { Facilidade de alterações de telas e } \\
\text { relatórios }\end{array}$ & $\begin{array}{l}\text { Configuração de telas } \theta \\
\text { relatórios }\end{array}$ & $\begin{array}{l}\text { Fácil de alterar a configuraçăo } \\
\text { de telas e relatórios }\end{array}$ \\
\hline 14 & $\begin{array}{l}\text { Ter possibilidade de registrar } \\
\text { informaçöes }\end{array}$ & $\begin{array}{l}\text { Clientes, fornecedores, } \\
\text { funcionários, produtos, cartão de } \\
\text { crédito, despesas }\end{array}$ & $\begin{array}{l}\text { Fácil de registrar os dados } \\
\text { cadastrais }\end{array}$ \\
\hline 15 & $\begin{array}{l}\text { Ter possibilidade de controlar a } \\
\text { abertura da mesa }\end{array}$ & Atendimento no saläo & $\begin{array}{l}\text { Fácil de registrar o pedido da } \\
\text { mesa }\end{array}$ \\
\hline 16 & $\begin{array}{l}\text { Ter possibilidade de registrar o } \\
\text { fechamento da mesa }\end{array}$ & Atendimento no salão & $\begin{array}{l}\text { Fácil de registrar o fechamento } \\
\text { da rnesa }\end{array}$ \\
\hline 17 & $\begin{array}{l}\text { Ter possibilidade de registrar o } \\
\text { recebimento da mesa }\end{array}$ & Atendimento no salão & $\begin{array}{l}\text { Fácil de registrar o recebimento } \\
\text { da mesa }\end{array}$ \\
\hline 18 & $\begin{array}{l}\text { Ter possibilidade de fazer } \\
\text { transferência de mesa } \\
\end{array}$ & Atendimento no salão & Fácil de transferir mesa \\
\hline 19 & $\begin{array}{l}\text { Ter possibilidade de fazer o } \\
\text { cancelarnento de mesa }\end{array}$ & Atendimento no salso & Fácil de cancelar mesa \\
\hline 20 & $\begin{array}{l}\text { Ter possibilidade de registrar } \\
\text { pedidos feitos por telefone }\end{array}$ & Atendimento no balcäo & $\begin{array}{l}\text { Fácil de registrar pedldos feitos } \\
\text { por telefone }\end{array}$ \\
\hline 21 & $\begin{array}{l}\text { Ter possibilidade de registrar o } \\
\text { fechamento do pedido }\end{array}$ & Atendimento no balcão & $\begin{array}{l}\text { Fácil de registrar o fecharnento } \\
\text { do pedido }\end{array}$ \\
\hline 22 & $\begin{array}{l}\text { Ter possibilidade de registrar o } \\
\text { recebirnento do pedido }\end{array}$ & Atendimento no balcāo & $\begin{array}{l}\text { Fácil de registrar o recebimento } \\
\text { do pedido }\end{array}$ \\
\hline 23 & $\begin{array}{l}\text { Ter possibilidade de fazer } \\
\text { transferência de pedido feito por } \\
\text { telefone }\end{array}$ & Atendimento no balcão & Fácil de transferir o pedido feito \\
\hline 24 & $\begin{array}{l}\text { Ter possibilidade de fazer o } \\
\text { cancelamento do pedido }\end{array}$ & Atendimento no balcão & Fácil de cancelar o pedido \\
\hline 25 & $\begin{array}{l}\text { Mostrar informaçōes referentes às } \\
\text { entradas e às saidas }\end{array}$ & $\begin{array}{l}\text { Entradas (dinheiro, cartăo de } \\
\text { crédito ou caderneta) Saidas } \\
\text { (produtos que foram vendidos) }\end{array}$ & $\begin{array}{l}\text { Exibir informaçס̄es referentes às } \\
\text { entradas e saídas }\end{array}$ \\
\hline
\end{tabular}


Tabela 7.1 - Obtenção dos Dados Originais - Cantina (continuação)

\begin{tabular}{|c|c|c|c|}
\hline$\overline{N^{\circ}}$ & DADOS ORIGINAIS & $\begin{array}{l}\text { DESDOBRAMENTO DA CENA } \\
\text { (quem, onde, quando, como, } \\
\text { por que) }\end{array}$ & REQUISITO DO CLIENTE \\
\hline 26 & $\begin{array}{l}\text { Ter possibilidade de exibir } \\
\text { informaçōes dos produtos } \\
\text { mais/menos vendidos }\end{array}$ & Estabelecimento & $\begin{array}{l}\text { Exibir informaçóes dos produtos } \\
\text { mais ou menos vendidos }\end{array}$ \\
\hline 27 & $\begin{array}{l}\text { Saber o grau de conhecimento } \\
\text { minimo necessário }\end{array}$ & Operaçåo do sistema & $\begin{array}{l}\text { Fácil de saber o nivel de } \\
\text { conhecimento }\end{array}$ \\
\hline 28 & $\begin{array}{l}\text { Saber se apresenta menus, } \\
\text { janelas, teclas de funçäo e de } \\
\text { auxílio }\end{array}$ & Sistema & $\begin{array}{l}\text { Fácil de saber se apresenta } \\
\text { menus, janelas, teclas de funçăo e } \\
\text { de auxilio }\end{array}$ \\
\hline 29 & $\begin{array}{l}\text { Indicar o tempo de resposta e de } \\
\text { execução dos dados }\end{array}$ & Pacote & $\begin{array}{l}\text { Fácil de saber o tempo de } \\
\text { resposta e de execuçăo dos dados }\end{array}$ \\
\hline 30 & $\begin{array}{l}\text { Ter procedimentos sobre como } \\
\text { fazer backup }\end{array}$ & Pacote & $\begin{array}{l}\text { Fácil de gerar cópias de } \\
\text { segurança }\end{array}$ \\
\hline 31 & $\begin{array}{l}\text { Apresentar as mesmas funçöes } \\
\text { que foram descritas na caixa do } \\
\text { pacote }\end{array}$ & Manual do usuário & $\begin{array}{l}\text { Fácil de saber se as informaçōes } \\
\text { apresentadas no manual do } \\
\text { usuário são as mesmas } \\
\text { apresentadas na caixa do pacote }\end{array}$ \\
\hline 32 & $\begin{array}{l}\text { Ter índice ou sumário para } \\
\text { visualizaçāo geral das } \\
\text { informaçōes }\end{array}$ & Manual do usuário & $\begin{array}{l}\text { Ter indice para facilitar acesso } \\
\text { geral às. informaçōes }\end{array}$ \\
\hline \multirow[t]{2}{*}{33} & \multirow{2}{*}{$\begin{array}{l}\text { Mostrar as telas em modo gráfico } \\
\text { com uma breve explicaçäo }\end{array}$} & \multirow[t]{2}{*}{ Manual do usuário } & Facil de visualizar as telas \\
\hline & & & $\begin{array}{l}\text { Fácil de entender as explicações } \\
\text { das telas }\end{array}$ \\
\hline 34 & Mostrar exemplos dos relatórios & Manual do usuário & $\begin{array}{l}\text { Fácil de entender os exemplos de } \\
\text { saída dos dados (relatórios) }\end{array}$ \\
\hline 35 & $\begin{array}{l}\text { As informaçóes devem ser } \\
\text { corretas e sem ambiguidades }\end{array}$ & Manual do usuário & $\begin{array}{l}\text { Apresentar as informações } \\
\text { corretas e sem ambigüidades }\end{array}$ \\
\hline 36 & $\begin{array}{l}\text { A linguagem utilizada deve ser } \\
\text { bem acessivel e não técnica }\end{array}$ & Manual do usuário & $\begin{array}{l}\text { Enterider facilmente a linguagem } \\
\text { utilizada }\end{array}$ \\
\hline 37 & $\begin{array}{l}\text { As informações devem ser } \\
\text { coerentes }\end{array}$ & Pacote e manual do usuário & $\begin{array}{l}\text { Ter coerència das informações } \\
\text { contidas no manual do usuário } \\
\text { com as informações contidas na } \\
\text { descrição da caixa }\end{array}$ \\
\hline 38 & $\begin{array}{l}\text { Ter consistência de vocabulário } \\
\text { entre as mensagens }\end{array}$ & $\begin{array}{l}\text { Dos programas e o manual do } \\
\text { usuário }\end{array}$ & $\begin{array}{l}\text { Ter consistência de vocabulário } \\
\text { entre as mensagens dos } \\
\text { programas e o manual do usuário }\end{array}$ \\
\hline 39 & $\begin{array}{l}\text { As mensagens, os formatos de } \\
\text { tela de entrada de dados e os } \\
\text { relatórios devem estar } \\
\text { estruturados de maneira uniforme }\end{array}$ & Uso do pacote & $\begin{array}{l}\text { Ter controle da operaçáo e do } \\
\text { comportamento do programa }\end{array}$ \\
\hline 40 & $\begin{array}{l}\text { Ter garantia dos dados mesmo } \\
\text { quando informar dados fora dos } \\
\text { limites especificados }\end{array}$ & Uso do pacote & $\begin{array}{l}\text { Ter controle do estado anormal } \\
\text { sem perder os dados }\end{array}$ \\
\hline 41 & $\begin{array}{l}\text { As mensagens na tela devem ser } \\
\text { claras }\end{array}$ & Uso do pacote & $\begin{array}{l}\text { Ser possível diferenciar } \\
\text { mensagens de confirmaçăo, de } \\
\text { consulta, de advertência e de erro }\end{array}$ \\
\hline 42 & $\begin{array}{l}\text { O formato das telas e de relatórios } \\
\text { devem ser claros }\end{array}$ & Uso do pacote & $\begin{array}{l}\text { Fácil de entender as telas e } \\
\text { relatórios }\end{array}$ \\
\hline 43 & $\begin{array}{l}\text { Ter mensagens de alerta quando } \\
\text { for excluir ou sobrepor alguma } \\
\text { informaçăo }\end{array}$ & Uso do pacote & $\begin{array}{l}\text { Ter mensagens de alerta quando } \\
\text { for excluir ou sobrepor alguma } \\
\text { informação }\end{array}$ \\
\hline 44 & $\begin{array}{l}\text { Ter um menu mostrando as } \\
\text { principais funçóes do pacote }\end{array}$ & Uso do pacote & $\begin{array}{l}\text { Ter um menu mostrando as } \\
\text { principais funçóes do pacote }\end{array}$ \\
\hline 45 & Ter tecias de auxilio para cada tela & Uso do pacote & Ter teclas de auxílio para cada tela \\
\hline$\overline{46}$ & Fácil de aprender a usar & Uso do pacote & Ser fácil de aprender a usar \\
\hline
\end{tabular}


Tabela 7.2 - Tabela de Desdobramento dos Requisitos do Cliente - Cantina

\begin{tabular}{|c|c|c|}
\hline $1^{0}$ Nivel & $2^{\circ}$ Nivel & $\begin{array}{c}\text { Grau de } \\
\text { importancle }\end{array}$ \\
\hline \multirow{3}{*}{$\begin{array}{l}\text { 1. Boas condiçöes para } \\
\text { compra }\end{array}$} & 1.1 Boa aparêncla aos olhos & \\
\hline & 1.2 Ser fácil de ler as informaçōes & \\
\hline & 1. 3 Ser fácil de entender as informações & \\
\hline \multirow[t]{4}{*}{ 2. Fácil de identificar } & 2.1 A caixa do produto & \\
\hline & 2.20 nome, versäo ou data do produto & \\
\hline & 2.30 nome e endereço do fomecedor & \\
\hline & 2.4 As principais tarefas & \\
\hline \multirow{11}{*}{$\begin{array}{l}\text { 3. Fácil de saber se as } \\
\text { informaçōes estão } \\
\text { declaradas }\end{array}$} & 3.1 Referência a documentos de requisitos & \\
\hline & 3.20 tipo de plataforma necessária & \\
\hline & 3.3 Integraçöes com outros produtos & \\
\hline & 3.40 responsável pela instaiaçāo & \\
\hline & 3.5 Ter manutençåo do software & \\
\hline & 3.6 Possibilidade de ser instalado em outro equipamento & \\
\hline & 3.7 Ter assistência & \\
\hline & 3.80 grau de conhecimento mínimo exigido & \\
\hline & 3.9 Apresentar o tempo de resposta e de execucão dos dados & \\
\hline & $\begin{array}{l}\text { 3.10 Apresentar procedimentos para gerar cópias de segurança dos } \\
\text { dados (backup) }\end{array}$ & \\
\hline & $\begin{array}{l}\text { 3.11 Apresentar facilidades de uso, tais como, menus, janelas, teclas de } \\
\text { funcáo e de auxilio }\end{array}$ & \\
\hline \multirow{2}{*}{$\begin{array}{l}\text { 4. Fácil de registrar } \\
\text { informaçōes }\end{array}$} & 4.1 Ter uma furlçāo para incluir dados cadastrais & \\
\hline & 4.2 Ter uma funçāo para controlar o atendimento no saiāo e no balcāo & \\
\hline \multirow[t]{2}{*}{$\begin{array}{l}\text { 5. Fácil de obter } \\
\text { informaçōes }\end{array}$} & $\begin{array}{l}\text { 5.1 Ter uma funçāo para exibir informaçōes referentes às entradas e } \\
\text { saidas }\end{array}$ & \\
\hline & $\begin{array}{l}5.2 \text { Ter uma funçāo para exibir informações dos produtos mais ou menos } \\
\text { vendidos }\end{array}$ & \\
\hline \multirow{6}{*}{$\begin{array}{l}\text { 6. Entender facilmerite o } \\
\text { manual do usuário }\end{array}$} & 6.1 Apresentar as iriformaçōes corretas e sem ambigüidades & \\
\hline & 6.2 Entender facilmente a linguagem utilizada & \\
\hline & 6.3 Ter indice para facilitar acesso gerai às informaçōes & \\
\hline & 6.4 Ser fácil de visualizar as telas & \\
\hline & 6.5 Ser fácil de entender as expiicaçōes das teias com exemplos & \\
\hline & 6.6 Ser fácil de entender os exemplos de saída dos dados (relatónios) & \\
\hline 7. Ser compieto & $\begin{array}{l}\text { 7.1 Manual do usuárlo deve apresentar as mesmas funçōes que foram } \\
\text { declaradas na calxa do produto }\end{array}$ & \\
\hline \multirow[t]{2}{*}{$\begin{array}{l}\text { 8. Ter consistência das } \\
\text { informaçöes }\end{array}$} & $\begin{array}{l}\text { 8.1 Possuir coeréncla das informaçóes contidas no manual do usuário } \\
\text { corn as informaçōes contidas na descrição da caixa do produto }\end{array}$ & \\
\hline & $\begin{array}{l}\text { 8.2 Ter consistência de vocabulário entre as mensagens dos programas e } \\
\text { o manual do usuárlo }\end{array}$ & \\
\hline \multirow[t]{10}{*}{ 9. Fácil de usar } & $\begin{array}{l}\text { 9.1 Ter controle da operação e do comportamento do programa em } \\
\text { execucáo }\end{array}$ & \\
\hline & 9.2 Ter controle do estado ariormal sem perder os dados & \\
\hline & $\begin{array}{l}\text { 9.3 Ser possivel diferenciar mensageris de confirmaçäo, de consulta, de } \\
\text { adverténcia e de erro }\end{array}$ & \\
\hline & 9.4 Ter um menu mostrando as prirıipals funçöes & \\
\hline & 9.5 Fácil de entender as telas a relatórios & \\
\hline & $\begin{array}{l}\text { 9.6 Ter mensagens de alerta quando for excluir ou sobrepor alguma } \\
\text { informaçảo }\end{array}$ & \\
\hline & 9.7 Ter teclas de auxillo para cada tela & \\
\hline & 9.8 Ser fácil de aprerider a usar & \\
\hline & 9.9 Ser fácil de alterar layout de relatórios & \\
\hline & 9.10 Ser fácii de usar & \\
\hline
\end{tabular}


- Ciclo de Determinação de Importância das Características do Pacote

Para auxiliar a condução da sessão de entrevista estruturada, realizada com o proprietário da cantina, foi elaborado um plano (Quadro 7.2).

O plano foi colocado em prática, preenchendo-se a terceira coluna com o grau de importância de cada uma das características do Pacote (Tabela 7.3).

As prioridades das caracteristicas do pacote foram validadas junto ao cliente.

Quadro 7.2 - Estrutura do Plano para a Sessão de Entrevista Estruturada

\section{PLANO PARA A SESSÃO DE ENTREVISTA ESTRUTURADA}

1 Introdução: o objetivo deste plano é orientar o Engenheiro de Conhecimento a conduzir uma sessão de entrevista estruturada,

\section{Gerenciamento}

Local da Sessão: Cantina Famiglia Dall' Agnol

Data de Sessão: 14/02/2000 Horário: 19:30

Tempo Total: 0:20

Engenheiro de Conhecimento: Jusane Farina Lara

Entrevistado/Fonte de Conhecimento: Darlan Dall' Agnol

Meta da Sessão: questionar sobre o grau de importância de cada uma das características do Pacote identificadas no cicio anterior.

\section{Tarefas:}

3.1 Deve ser explicado ao entrevistado que suas informações na entrevista são importantes para a seleção do pacote de software.

3.2 Apresentar a Tabela de Desdobramento dos Requisitos do Cliente (TDRC) e questionar o Cliente quanto d̀ prioridade dos requisitos.

3.3 A escala de valores possiveis para o grau de importância deve ser de um (1) a cinca (5). O valor um (1) corresponde a nenhuma importância, o valor dois (2) corresponde a pouca importância, o valor três (3) corresponde a alguma importância, o valor quatro (4) corresponde a importante e o valor cinco (5) corresponde a muito importante.

4 Cronograma: $O$ entrevistado deve gastar até 30 minutos para responder as questöes.

5 Recursos: o local selecionado para a entrevista deve ser isolado de quaisquer outras pessoas que não façam parte da sessäo, para que não haja interferência na lógica de raciocínio do Cliente. 
Tabela 7.3 - Tabela de Desdobramento dos Requisitos do Cliente com o Grau de Importância - Cantina

\begin{tabular}{|c|c|c|}
\hline $1^{\circ}$ Nivel & $2^{\circ}$ Nivel & $\begin{array}{c}\text { Grau de } \\
\text { Importancia' }\end{array}$ \\
\hline \multirow{3}{*}{$\begin{array}{l}\text { 1. Boas condiçōes para } \\
\text { compra }\end{array}$} & 1.1 Boa aparêncla aos olhos & 5 \\
\hline & 1.2 Ser fácil de ler as informaçōes. & 5 \\
\hline & 1. 3 Ser fácii de entender as informaçōes & 5 \\
\hline \multirow[t]{4}{*}{ 2. Fácil de identificar } & 2.1 A caixa do produto & 5 \\
\hline & 2.20 nome, versáo ou data do produto & 5 \\
\hline & 2.30 nome e endereco do fornecedor & 5 \\
\hline & 2.4As principais tarefas & 5 \\
\hline \multirow{11}{*}{$\begin{array}{l}\text { 3. Fácil de saber se as } \\
\text { informaçסes estäo } \\
\text { declaradas }\end{array}$} & 3.1 Referéncla a documentos de requisitos & 5 \\
\hline & 3.20 tipo de plataforma necessánia & 5 \\
\hline & 3.3 integraçoes com outros produtos & 4 \\
\hline & 3.40 responsável pela instalaçăo & 4 \\
\hline & 3.5 Ter manutencăo do software & 5 \\
\hline & 3.6 Possibillidade de ser instalado em outro equipamento & 4 \\
\hline & 3.7 Ter assistência & 4 \\
\hline & 3.80 grau de conhecimento minimo exigido & 3 \\
\hline & 3.9 Apresentar o tempo de resposta e de execuça dos dados & 3 \\
\hline & $\begin{array}{l}\text { 3.10 Apresentar procedimentos para gerar cópias de segurança dos dados } \\
\text { (backup) }\end{array}$ & 4 \\
\hline & $\begin{array}{l}\text { 3.11 Apresentar facilidades de uso, tals como, menus, janelas, tecias de } \\
\text { funçäo e de auxillio }\end{array}$ & $\overline{4}$ \\
\hline \multirow{2}{*}{$\begin{array}{l}\text { 4. Fácll de registrar } \\
\text { informaçōes }\end{array}$} & 4.1 Ter uma função para incluir dados cadastrais & 4 \\
\hline & 4.2 Ter uma função para controlar o atendimento no salāo e no balcão & 5 \\
\hline \multirow{2}{*}{$\begin{array}{l}\text { 5. Fácil de obter } \\
\text { informaçbes }\end{array}$} & 5.1 Ter uma função para exibir informaçöes referentes às entradas e saidas & 5 \\
\hline & $\begin{array}{l}5.2 \text { Ter uma funçāo para exibir intormaçōes dos produtos mais ou menos } \\
\text { vendidos }\end{array}$ & 5 \\
\hline \multirow{6}{*}{$\begin{array}{l}\text { 6. Entender facilmente o } \\
\text { manual do usuário }\end{array}$} & 6.1 Apresentar as informaços corretas e sem ambigojidades & 5 \\
\hline & 6.2 Entender facilmente a linguagem utilizada & 4 \\
\hline & 6.3 Ter índice para facilitar acesso geral às informaçöes & 5 \\
\hline & 6.4 Ser fácll de visualizar as telas & 4 \\
\hline & 6.5 Ser fácil de entender as explicaçöes das telas com exemplos & 4 \\
\hline & 6.6 Ser fácil de entender os exemplos de saida dos dados (reiatórios) & 3 \\
\hline 7. Ser completo & $\begin{array}{l}\text { 7.1 Manual do usuário deve apresentar as mesmas funçōes que foram } \\
\text { declaradas na caixa do produto }\end{array}$ & 4 \\
\hline \multirow[t]{2}{*}{$\begin{array}{l}\text { 8. Ter consistência das } \\
\text { informaçōes }\end{array}$} & $\begin{array}{l}\text { 8.1 Possuir coerência das informaçoes contidas no manual do usuário com } \\
\text { as informaçōes contidas na descriça da caixa do produto }\end{array}$ & 4 \\
\hline & $\begin{array}{l}\text { 8.2 Ter consistēncia de vocabuláno entre as mensagens dos programas } \theta 0 \\
\text { manual do usuário }\end{array}$ & 4 \\
\hline \multirow[t]{10}{*}{ 9. Fácil de usar } & $\begin{array}{l}\text { 9.1 Ter controle da operaçåo e do comportamento do programa em } \\
\text { execução }\end{array}$ & 5 \\
\hline & 9.2 Ter controle do estado anormal sem perder os dados & 5 \\
\hline & $\begin{array}{l}\text { 9.3 Ser possivel diferenciar mensagens de confirmação, de consulta, de } \\
\text { advertência e de erro }\end{array}$ & 4 \\
\hline & 9.4 Ter um menu mostrando as principais funçōes & 4 \\
\hline & 9.5 Fácil de entender as telas e relatórios & 4 \\
\hline & $\begin{array}{l}\text { 9.6 Ter mensagens de alerta quando for excluir ou sobrepor alguma } \\
\text { Informaçá }\end{array}$ & 4 \\
\hline & 9.7 Ter teclas de auxílio para cada tela & 4 \\
\hline & 9.8 Ser facil de aprender a usar & 5 \\
\hline & 9.9 Ser fácil de alterar layout de relatórios & 5 \\
\hline & 9.10 Ser fácil de usar & 5 \\
\hline
\end{tabular}

\footnotetext{
${ }^{1}$ Escala de Likert: 1 - nenhuma importância 2 - pouca importância 3 -alguma importância 4 - importante 5 muito importarite
} 


\section{- Construção da Matriz Casa da Qualldade}

Para a construção da matriz Casa da Qualidade utilizou-se a ferramenta QFDT (Quality Function Deployment Tool) descrita no Apêndice A.

A tabela de desdobramento dos requisitos do cliente produzida pelo processo de aquisição de cornhecimento IPAIA, instanciado para o domínio QFD - Casa da Qualidade, determinaram as "linhas" da matriz Casa da Qualidade. As informações contidas na Tabela 7.3 que correspondem aos desdobramentos dos requisitos do cliente e ao grau de importância, foram transcritas para o lado esquerdo da matriz (Figura 7.1). Nas "colunas" da matriz foram colocadas as caracteristicas de qualidade para pacote de software. Em seguida, realizou-se a correlação entre os requisitos do cliente com as características de pacote de software, conforme o procedimento descrito na seção 5.3 do Capítulo 5 . Finalmente, a ferramenta QFDT gerou o grau de importância das características de pacote apresentadas na última linha da matriz da Figura 7.1.

Em função do formato de apresentação, a ferramenta QFDT fez uma pequena modificação no modo de cálculo do grau de importância (última linha da matriz da Figura 7.1), o que não altera o percentual final de cada característica do pacote de software. A alteração está relatada no Quadro 7.3.

Quadro 7.3 -'Procedimento para obter o Grau de Importância das Caracteristicas de Pacote

a) Obter a antepenúltima linha da matriz Casa da Qualidade como apresentada na seção 5.3 do Capitulo 5.

b) Realizar o somatório da coluna "grau de importância dos requisitos do cliente".

c) Realizar o somatório da linha "grau de importância das caracteństicas de pacote" obtido no item a).

d) Calcular a proporção, dividindo o valor obtido no item b) pelo valor obtido no item c).

e) Multiplicar a proporção obtida no item d) por cada valor da linha do item a). 


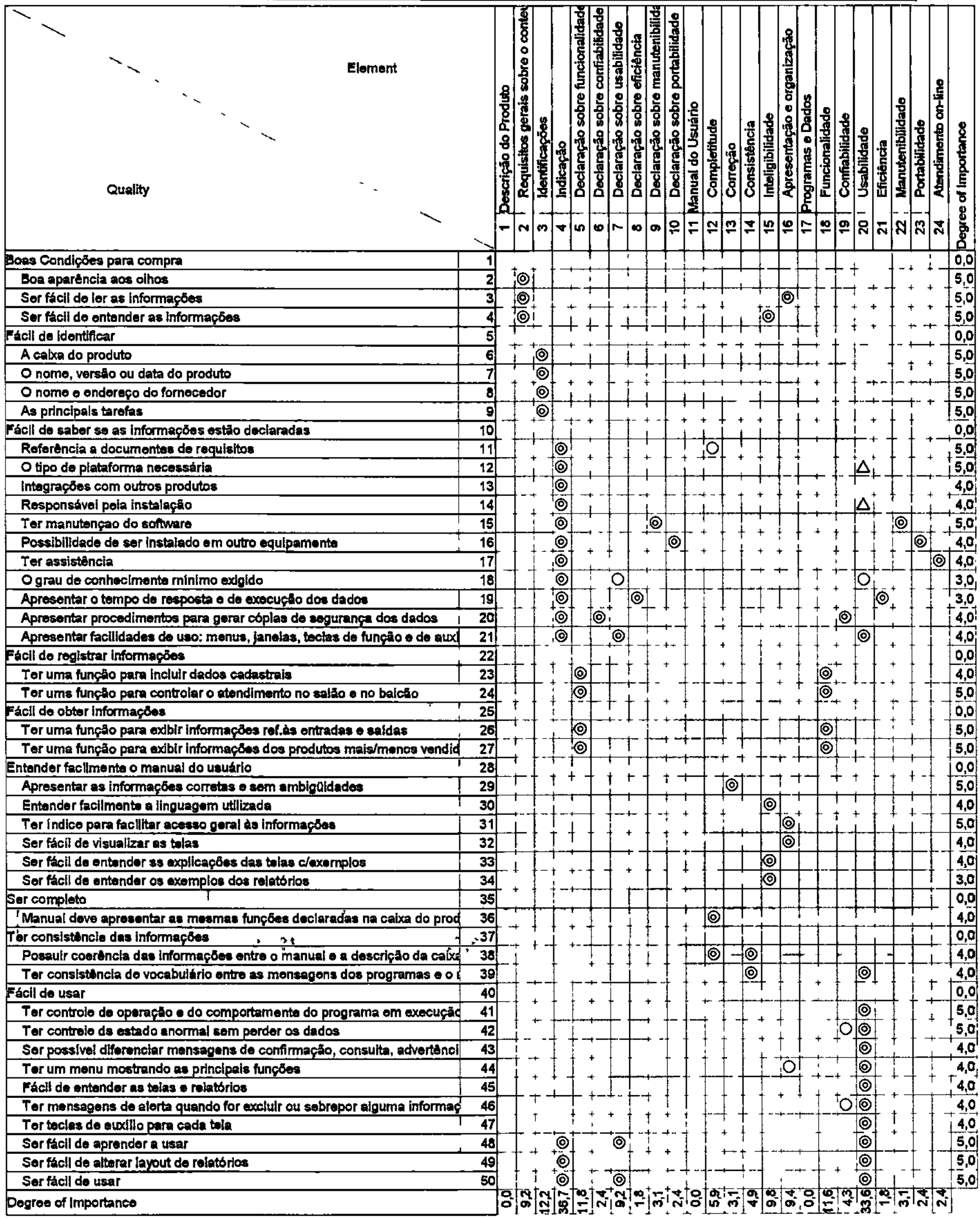

Figura 7.1 - Matriz Casa da Qualldade - Cantina 
Para realizar a geração do grau de importância das características de pacote, deve-se converter os valores do grau de importância (última linha da matriz da Figura 7.1) em valores percentuais. Para isso, deve-se seguir os passos descritos abaixo:

a) Transcrever os valores da última linha da matriz da Figura 7.1 para as colunas correspondentes da matriz da Tabela 7.4;

b) Realizar o somatório para os valores das colunas correspondentes a cada característica de pacote: descrição do produto, manual do usuário e programas e dados da matriz da Tabela 7.4. Transcrever o resultado para as colunas correspondentes da Tabela 7.4;

c) Realizar o somatório dos valores obtidos no item b). Transcrever o resultado para a célula " $\Sigma$ Grau de Importância das Características de Pacote";

d) Transformar os valores obtidos na penúltima linha da matriz da Tabela 7.4 na base $100 \%$. Transcrever os resultados para a última linha da matriz da Tabela 7.4 nas colunas correspondentes.

Tabela 7.4 - Geração do Grau de Importância em Percentagem - Cantina

\begin{tabular}{|c|c|c|c|c|c|c|c|c|c|c|c|c|c|c|c|c|c|c|}
\hline \multirow{2}{*}{ Requisitos do Cliente } & \multirow{2}{*}{ 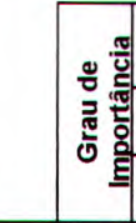 } & \multicolumn{17}{|c|}{ Características de Pacote de Software } \\
\hline & & \multicolumn{7}{|c|}{ Descrição do Produto } & \multicolumn{5}{|c|}{$\begin{array}{l}\text { Manual do } \\
\text { Usuário }\end{array}$} & \multicolumn{5}{|c|}{ Programas e Dados } \\
\hline & & & & & & & & & & & & & & & & & & \\
\hline & & & & & & & & & & & & & & & & & - & \\
\hline & & & & & & & & & & & & & & & 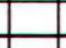 & . & 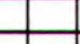 & \\
\hline $\begin{array}{l}\text { Grau de Importância das } \\
\text { Características de Pacote }\end{array}$ & & $\approx$ & $\stackrel{\sim}{\mathrm{N}}$ & : & 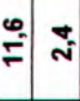 & $\approx$ & $\stackrel{\infty}{-}:$ & $\bar{m}$ & 6 & $\bar{m}$ & $\stackrel{9}{+} a_{0}^{\infty}$ & क & $\stackrel{\infty}{=}$ & $=9$ & 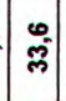 & $\stackrel{\infty}{=} \bar{m}$ & $=\frac{a}{4}$ & $\stackrel{4}{a}$ \\
\hline $\begin{array}{l}\text { Grau de Importância das } \\
\text { Características de Pacote } \\
\end{array}$ & $=180,90$ & & & & 88, & & & & & & 33,1 & & & & & 59,2 & & \\
\hline Necessidades do Cliente (\%) & & & & & 48,9 & & & & & & 8,30 & & & & & 2,73 & & \\
\hline
\end{tabular}




\subsection{2 - Avaliação do Pacote de Software - Cantina}

A Cantina possui um Sistema de Controle e Automação de Restaurantes denominado Fast Food. Esse sistema foi adquirido da empresa Soft Logic Informática, localizada na cidade de São Paulo (SP), através do seu representante local de software, Electra Informática Ltda. - Fast food é um sistema que tem como objetivo controlar 0 atendimento do estabelecimento, permitir o controle no salão e dos pedidos feitos por telefone com retirada no balcão, assim como, imprimir os comprovantes com a especificação do pedido para entregar aos clientes e à cozinha.

Para a avaliação do pacote de software Fast Food analisou-se a descrição do produto apresentada na embalagem, o manual do usuário que acompanha a caixa e a avaliação do pacote através da utilização do sistema. $O$ engenheiro de conhecimento responsável pela avaliação foi a própria autora deste trabalho de mestrado.

O pacote de software Fast Food foi avaliado aplicando-se as métricas definidas no Capitulo 6.

Para medição, os questionánios do Quadro 7.4 foram respondidos considerando-se o pacote de software Fast Food.

Primeiramente, somou-se as notas das respostas das características de qualidade obtendo-se a nota de cada requisito de qualidade.

Posteriormente, contou-se a quantidade de questões existentes para cada requisito de qualidade. Para 0 requisito de qualidade descrição do produto tem-se 23 questões que multiplicado por dois (2) que é a nota máxima obtida para cada resposta, obteve-se 46 para a nota máxima. Para os demais requisitos de qualidade repetiu-se o mesmo procedimento.

Finalmente, converteu-se a nota de cada requisito de qualidade em valor percentual. Para isso, dividiu-se o valor de cada célula correspondente a nota pela nota máxima e multiplicou-se por 100. Para o requisito de qualidade descrição do produto, dividiu-se a nota cujo valor é 19 pela nota máxima cujo valor é 46 , multiplicado por 100, obteve-se o resultado $41 \%$. Para os demais requisitos de qualidade repetiu-se o mesmo procedimento. 
Quadro 7.4 - Avaliação do Pacote de Software - Cantina

\begin{tabular}{|c|c|}
\hline REQUISITO DE QUALIDADE: DESCRIÇAO DO PRODUTO & 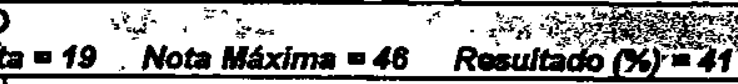 \\
\hline MEDIDAS & RESPOSTAS \\
\hline Caracteristica de Qualidade: Requisitos Gerais sobro o c & ontoúdo da descriçäo do produto \\
\hline $\begin{array}{l}\text { 1. O conteúdo da descriçāo do produto está inteligivel, completo e } \\
\text { possut boa organizaçăo e apresentaçẩo? }\end{array}$ & $\begin{array}{l}\text { 0. Nāo. A descriçăo está multo técnica } \\
\text { 1.V Algumas partes estáo dificels de compreender } \\
\text { 2. Sim. Geralmente }\end{array}$ \\
\hline Caracteristica de Qualidade: identificaç5o & \\
\hline $\begin{array}{l}\text { 2. O documento da descriçăo do produto possui uma única } \\
\text { identificaçăo? }\end{array}$ & $\begin{array}{ll}\text { Nato } \\
2 . \checkmark \text { Sim }\end{array}$ \\
\hline $\begin{array}{l}\text { 3. A identiflcacăo do produto possul o nome do produto e uma } \\
\text { versáo ou data? }\end{array}$ & $\begin{array}{ll}0 . & \text { Nà̃o } \\
2 . \checkmark & \text { Sim }\end{array}$ \\
\hline $\begin{array}{l}\text { 4. A identificaçåo do fornecedor contém o nome e o endereço de, } \\
\text { no mínimo, um fornecedor? }\end{array}$ & $\begin{array}{l}\text { 0. Nâa } \\
2 . \checkmark \text { Sim }\end{array}$ \\
\hline $\begin{array}{l}\text { 5. Existe indicaçåo das tarefas que podem ser realizadas utilizando } \\
\text { o produto? }\end{array}$ & $\begin{array}{l}\text { O. Nă } \\
\text { 2. } \\
\text { Sim }\end{array}$ \\
\hline $\begin{array}{l}\text { 6. A descriçåo do produto faz referéncia sos documentos de } \\
\text { requisitos com os quais o produto está em conformidade? }\end{array}$ & $\begin{array}{l}\text { O. Nåo } \\
\text { 1. Faz referêncla apenas para alguns documentos } \\
\text { 2. Sim } \\
\end{array}$ \\
\hline Caracteristica de Qualidade: Indicaçäo & \\
\hline $\begin{array}{l}\text { 7. Existe indicaçato dos requisitos de hardware e soltware para } \\
\text { colocar o produto em uso, ou seja, nomes de fabricantes e } \\
\text { ldentfilcaçăo do tipo de todos os componentes? }\end{array}$ & $\begin{array}{l}\text { Năo } \\
\text { 1. } \text { Alguns requisitos eståo Identificados, não todos } \\
\text { 2. Sim. Todos os requisitos estāo identificados }\end{array}$ \\
\hline $\begin{array}{l}\text { 8. Se a descriçăo do produto faz referências a interfaces com } \\
\text { outros produtos, essas interfaces ou produtos eståo } \\
\text { identificados? }\end{array}$ & 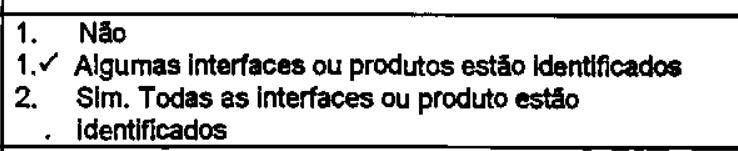 \\
\hline $\begin{array}{l}\text { 9. Todo componente fisico do produto fomecido está identificado, } \\
\text { incluindo todos os documentos impressos e todos os meios de } \\
\text { armazenamento? }\end{array}$ & $\begin{array}{ll}0 . \checkmark \text { Não } \\
\text { 1. Alguns componentes físico estáo identificados } \\
\text { 2. Sim. Todos os componentes físicos estâo identificados }\end{array}$ \\
\hline $\begin{array}{l}\text { 10. A descriçáo do produto fornece uma declaraçăo indicando se a } \\
\text { instalaça do produto é oferecida ou não? }\end{array}$ & $\begin{array}{ll}0 . \checkmark & \text { Năo } \\
\text { 2. } & \text { Sim }\end{array}$ \\
\hline $\begin{array}{l}\text { 11. A descriçăo do produto fornece uma declaraça indicando se a } \\
\text { manutenģa do produto é oferecida ou não? }\end{array}$ & $\begin{array}{l}\text { O. Não } \\
\text { 2. Sim }\end{array}$ \\
\hline Caracteristica de Qualidade: Declaração sobro Funcional & lidade \\
\hline $\begin{array}{l}\text { 12. A descriçăo do produto fornece uma visăo geral das funç̧es } \\
\text { disponiveis para o usuárlo do produto, os dados necessários e } \\
\text { as facilidades oferecidas? }\end{array}$ & 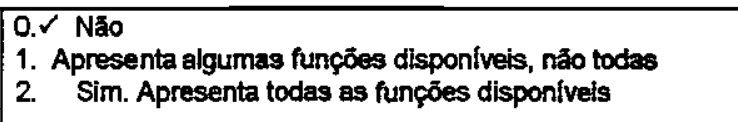 \\
\hline $\begin{array}{l}\text { 13. Os valores limite săo especificados para todos os dados de } \\
\text { entrada que deverếo ser testados? }\end{array}$ & \begin{tabular}{ll|}
$0 . \checkmark$ & Nāo \\
1. Apresenta alguns valores limite \\
2. Sim. Apresenta todos os valores limite \\
\end{tabular} \\
\hline $\begin{array}{l}\text { 14. A descriçăo do produto incluł Informaçes a respelto de } \\
\text { maneiras, se fomecidas, para evitar o acesso năo autorlzado } \\
\text { (acidental ou intenclonal) a programas e dados? }\end{array}$ & $\begin{array}{l}\text { 0.V Não } \\
\text { 1. Apresenta algumas informaçōes } \\
\text { 2. Sim. Apresenta todas as informaçōes }\end{array}$ \\
\hline
\end{tabular}


Quadro 7.4 - Avaliação do Pacote de Software - Cantina (continuação)

\begin{tabular}{|c|c|}
\hline \multicolumn{2}{|c|}{ 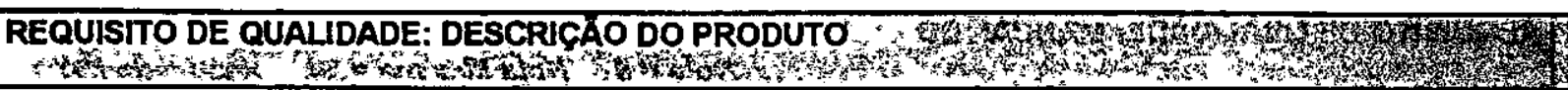 } \\
\hline MEDIDAS & RESPOSTAS \\
\hline \multicolumn{2}{|l|}{ Caracteristica de Qualidade: Declaraça sobre Confiabilidade } \\
\hline $\begin{array}{l}\text { 15. Existe uma deciaraçāo dizendo como se deve fazer backup } \\
\text { (através do Sistema Operacional ou de um comando especifico } \\
\text { contido no software produto)? }\end{array}$ & $\begin{array}{ll}0 . & \text { Não } \\
2 . \checkmark \text { Sim }\end{array}$ \\
\hline $\begin{array}{l}\text { 16. É possivei reverter funçठ̄es do efeito drástico decorrentes de erro } \\
\text { de usuánio? }\end{array}$ & $\begin{array}{ll}\text { 0. Nāo } \\
\text { 1. As vezes, não sempre } \\
\text { 2. Silm. Geraimente }\end{array}$ \\
\hline \multicolumn{2}{|c|}{ Caracteristica de Qualidade: Declaraçäo sobre Usabilidade } \\
\hline $\begin{array}{l}\text { 17. O tipo de interface com o usuário está especificado na descrição } \\
\text { do produto, por exemplo, menu, Janeias, teclas de funçăo, funçăo } \\
\text { de help? }\end{array}$ & 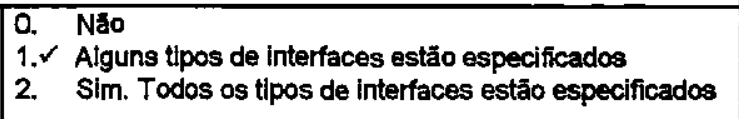 \\
\hline $\begin{array}{l}\text { 18. Se é necessário conhecimento especifico para a aplicação do } \\
\text { produto, este conhecimento especifico exdgido está descrito na } \\
\text { descriçăo do produto? }\end{array}$ & $\begin{array}{ll}0 . \checkmark & \text { Nåo } \\
2 . & \text { Sim }\end{array}$ \\
\hline $\begin{array}{l}\text { 19. Se o produto pode ser adaptado peio usuário, entảo as } \\
\text { ferramentas para essa adaptação e as condiçðes para seu uso } \\
\text { estáo identificadas? (exemplos: mudança de parâmetros, } \\
\text { mudança de algortmos para computaçāo e atribuiçăo de tectas } \\
\text { de função). }\end{array}$ & 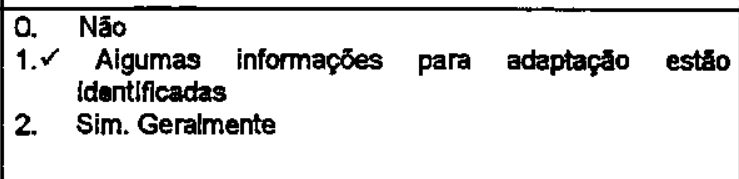 \\
\hline $\begin{array}{l}\text { 20. Se a proteção técnica contra infraçöes a direitos autorais pode } \\
\text { difficuitar a usabilidade, entáo essa proteçåo está deciarada? } \\
\text { (exempios: proteção técnica contra cópias, datas programadas } \\
\text { de expiração de uso, lembretes interativos para pagamento por } \\
\text { cópla) }\end{array}$ & $\begin{array}{ll}\text { O.V } & \text { Não } \\
\text { 1. } & \text { Algumas informaçōes estäo declaradas } \\
\text { 2. } & \text { Sim. Geralmente }\end{array}$ \\
\hline \multicolumn{2}{|l|}{ Característica de Qualidade: Declaraçäo sobre Eficiência } \\
\hline $\begin{array}{l}\text { 21. A descricãa do produto possui dados sobre o comportamento do } \\
\text { produto em relaçăo ao tempo, tais como tempo de resposta e de } \\
\text { processamento e a velocidade de execuçäo? }\end{array}$ & $\begin{array}{ll}0 . \checkmark & \text { Năo } \\
2 . & \text { Sim }\end{array}$ \\
\hline \multicolumn{2}{|c|}{ Caracteristica de Qualidade: Declaraçäo sobre Manutenibilldade } \\
\hline $\begin{array}{l}\text { 22. A descriçăo do produto contém deciaraçöes que evidenciam o } \\
\text { esforço necessário para fazer modificaçöes especificadas no } \\
\text { software? }\end{array}$ & $\begin{array}{ll}0 . \checkmark & \text { Nåo } \\
\text { 2. } & \text { Sim }\end{array}$ \\
\hline \multicolumn{2}{|l|}{ Característica de Qualidade: Declaraçäo sobro Portabllidade } \\
\hline $\begin{array}{l}\text { 23. A descriçăo do produto contém deciaraçôes que evidenciam a } \\
\text { capacidade do software ser transferido de um amblente para } \\
\text { outro? }\end{array}$ & $\begin{array}{ll}0 . & \text { Näo } \\
2 . \checkmark \operatorname{Sim}\end{array}$ \\
\hline
\end{tabular}


Quadro 7.4 - Avaliação do Pacote de Software - Cantina (continuação)

\begin{tabular}{|c|c|}
\hline REQUISITO DE QUALIDADE: MANUAL DO USUÁRIO & 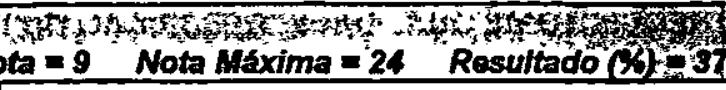 \\
\hline MEDIDAS & RESPOSTAS \\
\hline Característica de Quailidade: Completitude & \\
\hline $\begin{array}{l}\text { 1. As informaçōes contidas na descrição do produto também estăo } \\
\text { inciuidas no manual do usuário? }\end{array}$ & 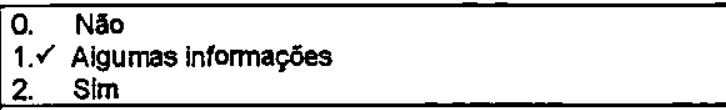 \\
\hline $\begin{array}{l}\text { 2. As informaçōes ausentes (que estảo faltando) estāo claramente } \\
\text { Identfficadas na norma com relaçăo a quando ou como a } \\
\text { informaçăo tornar-se-á disponivel e será incluida no manual do } \\
\text { usuário? }\end{array}$ & 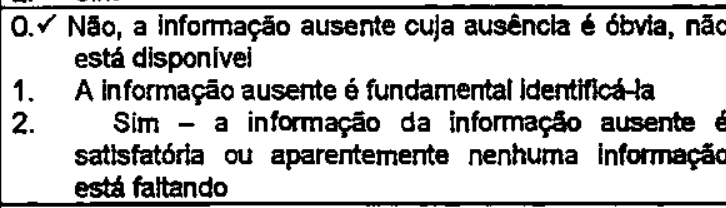 \\
\hline $\begin{array}{l}\text { 3. O manual do usuário possui exempios de telas (menus, etc) que } \\
\text { poderiam ser encontradas durante a execuç̧o do software? }\end{array}$ & $\begin{array}{l}\text { O.Váo. Somente figuras das teias principais são } \\
\text { mostradas } \\
\text { 1. Figuras de telas, menus, etc, são mostrados mas seus } \\
\text { conteúdos nắo sáo mostrados } \\
\text { 2. Sim - o número e a qualidade das figuras do telas no } \\
\text { manual do usuário são satisfatórios }\end{array}$ \\
\hline Característlica de Qualidade: Correção & \\
\hline $\begin{array}{l}\text { 4. As Informaçöes contidas no manuai do usuário estăo corretas, ou } \\
\text { seja, sem ambigúidades e erros? }\end{array}$ & $\begin{array}{l}\text { 0. Nåo } \\
\text { 1. } \text { Algurnas informaçð̈es estäo ambiguas } \\
\text { 2. Sim, todas } \\
\end{array}$ \\
\hline Característlca de Qualidade: Cons/stência & \\
\hline $\begin{array}{l}\text { 5. Os documentos do manual do usuário não apresentam } \\
\text { contradiçōes entre si e com a descriçāo do produto? }\end{array}$ & $\begin{array}{l}\text { 0. Quase sempre apresentam contradiçð̄es } \\
\text { 1. Usuaimente, mas nāo sempre } \\
\text { 2. Geraimente năo apresentam contradiç̋̄es }\end{array}$ \\
\hline $\begin{array}{l}\text { 6. A tabela do conteúdo está consistente com o conteúdo do manual } \\
\text { com respeito à paginaçāo, títulos e numeração? }\end{array}$ & $\begin{array}{l}0 . \checkmark \text { Näo ou nenhuma tabela de conteúdo foi encontrada } \\
\text { 1. Menos do que } 5 \text { inconsistências foram encontradas } \\
\text { 2. Sim } \\
\end{array}$ \\
\hline $\begin{array}{l}\text { 7. Quando a diretriz (norma) no manual do usuário, descreve } \\
\text { funçoses especificas do software, sáo observadas se a função } \\
\text { executa como o esperado (ou seja, as consequeencias da } \\
\text { execução da funçăo, de fato, sāo como as descritas no manual } \\
\text { do usuário)? }\end{array}$ & $\begin{array}{l}\text { 0. Não } \\
\text { 1. Algumas funçōes executam como o esperado } \\
\text { 2. Sim, todas as funçōes executam como o esperado }\end{array}$ \\
\hline $\begin{array}{l}\text { 8. Os termos definidos no manual do usuário estão ex } \\
\text { consistentemente? }\end{array}$ & $\begin{array}{|lr|}0 . & \text { Năo } \\
1 . \checkmark & \text { Usu } \\
\text { 2. Sim. } & \text { Sim } \\
\end{array}$ \\
\hline
\end{tabular}

Característica de Qualidade: Inteligibilidade

9. O manual do usuário está bem escrito e de fácil entendimento $0 . \quad$ Nāo. O manuai está multo técnico para um leltor sem nenhum conhecimento (background) do sistema?

1. Algumas partes estāo dificeis de compreender

2. Sim, geraimente

\section{Característica de Quaijdade: Apresentação e Organização}

10. O manual do usuário inclù uma lista de referénclas para outros documentos importantes com relação ao sistema atuah?
1. A lista de referência está desestruturada / incompleta / dificil para usar

2. Sim, a lisla de referência está suficientemente completa e proveltosa ou aparentemente, outros documentos nảo săo essenciałs para o entendimento do usuário com relacăo ao sistema

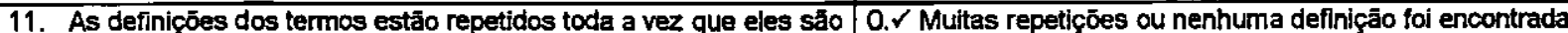
encontrados no texto ou essas definiçōes estảo incluidas nas 1. Algumas repetiçōes referências?

2. Referências para definiçőes únicas

$0 . \checkmark$ Näo

1. Figuras, etc, săo usadas ramente

2. Figuras, etc, sāo usadas extensivamente 
Quadro 7.4 - Avaliação do Pacote de Software - Cantina (continuação)

\begin{tabular}{|c|c|}
\hline $\begin{array}{r}\text { REQUISITO DE QỤALIDADE: PROGRAMAS E DADOS } \\
\text { Not }\end{array}$ & 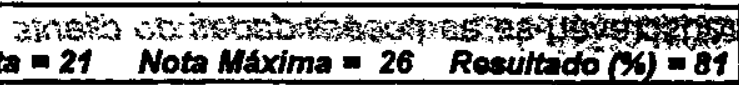 \\
\hline MEDIDAS & RESPOSTAS \\
\hline \multicolumn{2}{|l|}{ Característica de Qualidade: Funcionalldade } \\
\hline $\begin{array}{l}\text { 1. Exjste um manual de instalação com instruçỏes detalhadas para o } \\
\text { usuário realizar a instalação dos programas? }\end{array}$ & $\begin{array}{l}\text { 0. Năo } \\
\text { 2.V Sim - ou aparentemente, a instalaçáo dos programas } \\
\text { näo é realizada pelo próprio usuário }\end{array}$ \\
\hline $\begin{array}{l}\text { 2. É possivel instalar os programas seguindo as informaçōes } \\
\text { contidas no manual de instalaçāo? }\end{array}$ & \begin{tabular}{|l|} 
O. Nāo \\
2. Sim - ou aparentemente, a instalaçăo dos programas \\
näo é realizada pelo próprio usuário
\end{tabular} \\
\hline $\begin{array}{l}\text { 3. É possivel verificar se uma instalaçáo dos programas fol bem } \\
\text { sucedida? }\end{array}$ & \begin{tabular}{|l|l|} 
O. & Nāo \\
2. Sim - ou aparentemente, a instalaçăo dos programas \\
nåo é realizada pelo próprio usuárlo
\end{tabular} \\
\hline $\begin{array}{l}\text { 4. O controle da operaçāo e do comportamento do programa pelo } \\
\text { usuário, por exemplo, mensagens, formatos de tela de entrada e } \\
\text { relatónios impressos estāo estruturados de maneira uniforme? }\end{array}$ & $\begin{array}{ll}\text { 0. } & \text { Năo } \\
\text { 1. } & \text { Algumas informaçōes estāo estruturadas } \\
\text { 2. Sim, todas }\end{array}$ \\
\hline $\begin{array}{l}\text { 5. Existe consistência de vocabulário entre as mensagens dos } \\
\text { programas } \theta \text { a documentaçăo? }\end{array}$ & $\begin{array}{ll}0 . & \text { Não } \\
2 . & \text { Sim }\end{array}$ \\
\hline \multicolumn{2}{|l|}{ Caracteristica de Quaiidade: Confiabllidade } \\
\hline $\begin{array}{l}\text { 6. Se os dados estiverem fora dos limites especificados, o usuário } \\
\text { conseguirá controlar esse estado anormal sem perder dados? }\end{array}$ & $+\cdots$ \\
\hline \multicolumn{2}{|l|}{ Caracteristica de Quaifidade: Usabilidade } \\
\hline $\begin{array}{l}\text { 7. As mensagens de erro apresentam informaç̧es necessárias } \\
\text { para a solução da situação de emo (por exemplo, uma referêrncia } \\
\text { a um item no manual do usuário)? }\end{array}$ & $\begin{array}{ll}0 . \checkmark & \text { Nảo } \\
2 . & \text { Sim }\end{array}$ \\
\hline $\begin{array}{l}\text { 8. Existe identlffcaçāo da funģåo do programa que está sendo } \\
\text { executada no momento? }\end{array}$ & 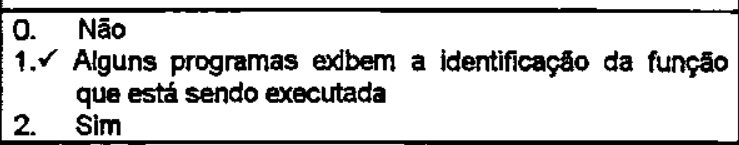 \\
\hline $\begin{array}{l}\text { 9. As mensagens dos programas foram projetadas de forma que o } \\
\text { usuário possa diferenclá-las pelo tipo (por exemplo, mensagens } \\
\text { de confimação, consulta, advertêncla e erro)? }\end{array}$ & 2. Nim \\
\hline 10. Exlste clareza nos formatos de telas de entrada e relatórios? & \begin{tabular}{|ll}
0. & $\mathrm{NaO}$ \\
$2 . \checkmark$ & $\mathrm{SIm}$ \\
\end{tabular} \\
\hline $\begin{array}{l}\text { 11. Na execução de funçōes como apagar dados ou sobrepô-los, } \\
\text { existe alertas claros para as consequâncias de uma determinada } \\
\text { confirmaçăo? }\end{array}$ & \begin{tabular}{|ll}
0. & Nä \\
$2 . \checkmark \mathrm{Sim}$
\end{tabular} \\
\hline $\begin{array}{l}\text { 12. Pode-se intertomper um processamento demorado sem Ter } \\
\text { consequénclas graves? }\end{array}$ & $\begin{array}{ll}0 . & \text { Nazo } \\
2 . \gamma & \text { Sim }\end{array}$ \\
\hline \multicolumn{2}{|l|}{ Caracteristica de Quaildade: AuxIlio (he/p) } \\
\hline $\begin{array}{l}\text { 13. Está disponivel atendimento on-line em caso de dúvida a respeito } \\
\text { do software produto? }\end{array}$ & $\begin{array}{ll}0 . \checkmark & \text { Năo } \\
\text { 2. } & \text { SIm }\end{array}$ \\
\hline
\end{tabular}


Para realizar o julgamento foi necessáno completar o Quadro 7.5. Para isso, transcreveu-se as necessidades do cliente (obtido em percentual na última linha da matriz da Tabela 7.4 da seção 7.2 .1$)$ para a respectiva coluna de "necessidades do cliente(\%)". Em seguida, transcreveu-se o resultado (obtido da avaliação do pacote do Quadro 7.4 da seção anterior) para a respectiva coluna "resultado(\%)". Finalmente, multiplicou-se o valor da coluna "necessidades do cliente" pelo valor em percentual da coluna "resultado(\%)", obtendo-se a coluna "proporção".

\section{Quadro 7.5 - Comparação das Necessidades do Cliente versus Avaliação do Pacote da Cantina}

\begin{tabular}{|c|c|c|c|}
\hline \multirow{2}{*}{$\begin{array}{l}\text { Características de Quailidade } \\
\text { de Pacote de Software }\end{array}$} & \multirow{2}{*}{$\begin{array}{l}\text { Necessidades } \\
\text { do cllente (\%) }\end{array}$} & \multicolumn{2}{|c|}{ Avaliaçăo do Pacote } \\
\hline & & Resultado(\%) & Proporção \\
\hline Descrição do Produto & 48,97 & 41 & 20,1 \\
\hline Manuai do Usuário & 18,30 & 37 & $\overline{6,8}$ \\
\hline Programas e Dados & 32,73 & 81 & 26,51 \\
\hline Valor I & 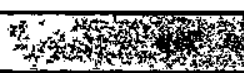 & & $\%$ \\
\hline
\end{tabular}

Para interpretar o Quadro acima deve-se comparar os valores que estão na coluna "necessidades do cliente" com os valores que estão na coluna "resultado(\%)". Por exemplo, analisando-se os valores da penúltima linha, as necessidades do cliente com relação a característica de pacote de software "programas e dados" foi $32,73 \%$ e o pacote avaliado atendeu $81 \%$. Proporcionalmente; obteve-se 26,51 dos 32,73 exigidos pelo cliente. Pode-se notar que na avaliação do pacote, a característica de qualidade programas e dados é a que está mais próxima das necessidades do cliente.

Somando-se os valores que estão na coluna "proporção", obtém-se 53,41\% para o valor medido que se refere ao resultado da avaliação do pacote de software da Cantina.

Como não houveram outros pacotes de cantina ou restaurantes para serem analisados, o cliente foi questionado sobre sua satisfação com relação ao pacote Fast Food. Segundo o cliente, ele está razoavelmente satisfeito com o pacote Fast Food, o que corresponde com o resultado obtido de $53,41 \%$ do atendimento do pacote com relação as suas reais necessidades. 


\section{3 - Caso 2 - Recursos Humanos (Unoesc)}

A Universidade do Oeste de Santa Catarina - UNOESC é uma instituição de ensino superior que atua nas áreas de graduação, pós-graduação, pesquisa e extensão. Localiza-se na regiäo oeste de Santa Catarina, na cidade de Chapecó. Atende mais de quatro mil alunos e possui trezentos e cinqüenta e oito funcionários administrativos e duzentos e cinqüenta e quatro professores mensalistas e horistas. O setor de Recursos Humanos é responsável pelo controle de toda a administração de pessoal da instituição.

Essa instituição tem interesse em adquirir um pacote de software que atenda as suas necessidades no que se refere a administração de recursos humanos.

\subsection{1 - Elaboração da Matriz Casa da Qualidade}

Para auxiliar a primeira etapa, foi utilizado o processo de aquisição de conhecimento IPAIA, instanciado para o domínio QFD - Casa da Qualidade.

\section{- Início do Processo de Aquisição de Conhecimento}

A área de aplicação do Pacote a ser adquirido refere-se a um sistema de controle de administração de recursos humanos. O patrocinador foi o Sr. Paulo Sérgio Jordani. Os potenciais membros da sessão de aquisição de conhecimento foram a Stra. Juliana Malvessi Lima, no papel do especialista de domínio, a Sra. Carla Lúcia Druzina Giongo, no papel de cliente e a própria autora deste trabalho de mestrado, no papel de engenheiro de conhecimento e anotador. O estimulo para a aplicação do processo foi realizado através de uma conversa inicial focalizando o que é aquisição de conhecimento, sua importância para a organização, os principais conceitos relacionados à aquisição de conhecimento como especialistas de domínio, engenheiro de conhecimento, entre outros.

Neste estudo de caso, para a obtenção das necessidades do cliente, foi necéssária uma única aplicação, tanto do primeiro ciclo auanto do segurin riclo do processo.

\section{- Ciclo de Visão Geral das Principais Necessidades do Pacote}

Para auxiliar a condução da sessão de brainstorming, realizada com os membros da equipe selecionada, elaborou-se um plano (Quadro 7.6), o qual foi entregue aos mesmos com dois dias de antecedência. 
Quadro 7.6 - Plano para a Sessão de Bralnstorming - Recursos Humanos

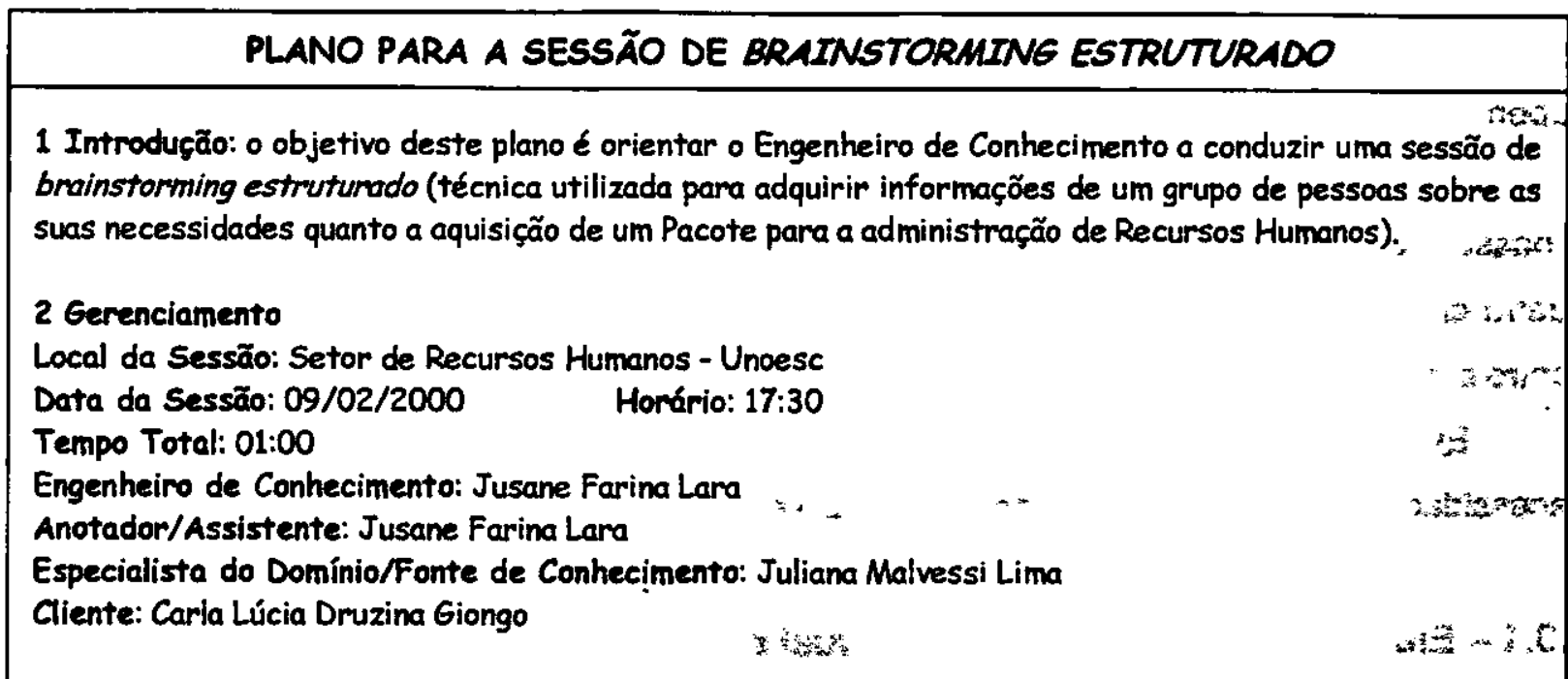

Meta da Sessão: adquirir uma visão geral do Siste ma de Recursos Humanos a ser adquirido e uma visão detalhada das características desse Pacote.

3 Tarefas:

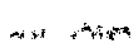

3.1 Iniciação: O objetivo dessa sessão de brainstorming está focado na obtenção de informações a respeito dos requisitos desejáveis em um Pacote de Software para Administração de Recursos Humanos.

3.20 engenheiro de conhecimento deve introduzir cada uma das funcionalidades consideradas na listagem de idéias:

3.3 Haverá um tempo disponivel para que o participante exponha o que conhece a respeito das funcionalidades que o sistema deverá ter, termos relacionados a essas funcionalidades e características gerais que o mesmo gostaria que o pacote fornecesse. $O$ engenheiro de conhecimento pode introduzir outras características que podem ser interessantes ao pacote.

3.40 anotador deve registrar as tarefas na coluna "Dados Originais" da Tabela 7.6:

3.5 Repetir as tarefas $3.2,3.3$ e 3.4 até que todas as funcionalidades identificadas tenham sido discutidas;

3.6 Converter os Dados Originais para Requisitos do Cliente;

\section{Cronograma:}

\begin{tabular}{|l|l|l|l|l|l|}
\hline Tarefas & 5 minutas & 15 minutos & 30 minutos & 45 minutos & 60 minutos \\
\hline 3.1 & & & & & \\
\hline 3.2 & & & & & \\
\hline 3.3 & & & & & \\
\hline 3.4 & & & & & \\
\hline 3.5 & & & & & \\
\hline 3.6 & & & & & \\
\hline
\end{tabular}

5 Recursos: no local onde ocorrerá a sessão, as cadeiras deverão estar dispostas em forma circular, para que todos se comuniquem, e $o$ anotador deverá ter papel e caneta para anotações. 
O plano foi colocado em prática; o engenheiro de conhecimento fez o papel de moderador na sessāo de brainstorming, de modo que, quando um estivesse se pronunciando e outro se lembrasse de algo para complementar, existisse ponderaçäo e bom senso para dar a palavra ao outro. As idéias foram registradas pelo anotador na coluna "Dados Originais" da Tabela 7.5. Após ter identificado todas as funcionalidades desejáveis do pacote, foi realizada a conversão desses dados originais para requisitos do cliente, completando a Tabela 7.5. Na seqüência, foi feita a seleção dos requisitos do cliente entre aqueles que se referem as reais necessidades do pacote. A partir dos requisitos do cliente selecionados, foi elaborada a tabela de desdobramento dos requisitos do cliente (Tabela 7.6) preenchendo-se apenas as duas primeiras colunas.

O conhecimento adquirido foi validado junto ao especialista de domínio, o cliente e o avaliador de pacote. Para isso, realizou-se uma inspeção para ser averiguada tanto a consistência quanto a completitude do conhecimento conceitual do domínio adquirido. Depois de realizada a inspeção notou-se que não haveria necessidade de realizar outro ciclo brainstorming; desse modo, o ciclo seguinte (de determinação de importância das características do pacote) foi realizado visando a obtenção do grau de importância para cada característica obtida no primeiro cicio. 
Tabela 7.5 - Obtenção dos Dados Originais - Recursos Humanos

\begin{tabular}{|c|c|c|c|}
\hline $\mathbf{N}^{\circ}$ & DADOS ORIGINAIS & $\begin{array}{c}\text { DESDOBRAMENTO DA CENA } \\
\text { (quem, onde, quando, como, } \\
\text { por que) }\end{array}$ & REQUISITO DO CLIENTE \\
\hline \multirow[t]{3}{*}{1} & \multirow{3}{*}{$\begin{array}{l}\text { Pacote deve ser de aparência } \\
\text { agradável }\end{array}$} & \multirow[t]{3}{*}{ Caixa do produto } & Visual bonito \\
\hline & & & Facil de ler \\
\hline & & & Fácil de entender \\
\hline 2 & Pacote deve ter um único título & Caixa do produto & Fácil de identificar \\
\hline 3 & $\begin{array}{l}\text { Apresentar descrição do nome, da } \\
\text { versáo e do fomecedor }\end{array}$ & Caixa do produto & $\begin{array}{l}\text { Ter conhecimento do nome, da } \\
\text { versão e do fornecedor }\end{array}$ \\
\hline 4 & $\begin{array}{l}\text { Deve apresentar o conteúdo da } \\
\text { embalagem }\end{array}$ & $\begin{array}{l}\text { Manuais, disco de 1,44 MB, CD- } \\
\text { ROM, etc }\end{array}$ & $\begin{array}{l}\text { Fácil de saber o conteúdo da } \\
\text { embalagem }\end{array}$ \\
\hline 5 & $\begin{array}{l}\text { Deve apresentar as principais } \\
\text { atividades }\end{array}$ & Utilização do produto & $\begin{array}{l}\text { Fácil de saber as principais } \\
\text { caracteristicas }\end{array}$ \\
\hline 6 & $\begin{array}{l}\text { Deve fazer referència aos } \\
\text { documentos disponiveis }\end{array}$ & Caixa do produto & $\begin{array}{l}\text { Fácil de saber se há referência a } \\
\text { documentos disponíveis }\end{array}$ \\
\hline 7 & $\begin{array}{l}\text { Deve descrever o tipo de } \\
\text { computador, quantidade de } \\
\text { memória, espaço em disco, } \\
\text { sistema operacional, unidades de } \\
\text { disco e cd-rom necessário }\end{array}$ & $\begin{array}{l}\text { Configuraçăo básica para } \\
\text { instalar o sistema }\end{array}$ & $\begin{array}{l}\text { Facil de saber a plataforma } \\
\text { necessária }\end{array}$ \\
\hline 8 & $\begin{array}{l}\text { Possibilidade de fazer integração } \\
\text { com outros módulos }\end{array}$ & Sistema & $\begin{array}{l}\text { Ter possibilidade de integraçöes } \\
\text { com outros módulos }\end{array}$ \\
\hline \multirow[t]{3}{*}{9} & \multirow{3}{*}{$\begin{array}{l}\text { Sistema deve rodar em ambiente } \\
\text { Windows }\end{array}$} & \multirow{3}{*}{$\begin{array}{l}\text { Windows 95, Windows 98, } \\
\text { Windows NT }\end{array}$} & Ambiente multi-usuário (rede) \\
\hline & & & $\begin{array}{l}\text { Fácil manuseio das entradas e } \\
\text { saídas }\end{array}$ \\
\hline & & & $\begin{array}{l}\text { Possibilidade para abrir várias } \\
\text { janelas e traba!har em paralelo }\end{array}$ \\
\hline 10 & Deve ser fácil de instalar & Sistema & Fácil de instalar \\
\hline 11 & $\begin{array}{l}\text { Deve ser possível solicitar } \\
\text { manutençáo }\end{array}$ & Sistema & Ter contrato de manutençäo \\
\hline 12 & $\begin{array}{l}\text { Fácil de instalar em outro } \\
\text { computador }\end{array}$ & Sistema & $\begin{array}{l}\text { Fácil de instalar em outro } \\
\text { equipamento }\end{array}$ \\
\hline 13 & $\begin{array}{l}\text { Ser fácil de tirar dúvidas por } \\
\text { telefone, internet, etc }\end{array}$ & Uso do Sistema & Ter contrato de assisténcia \\
\hline 14 & $\begin{array}{l}\text { Ter possibilidade de processar } \\
\text { cálcujos tanto para professores } \\
\text { como para funcionários }\end{array}$ & $\begin{array}{l}\text { Férias, } 13^{\circ} \text { salário, rescisão } \\
\text { contratual, folha de pagamento, } \\
\text { etc }\end{array}$ & $\begin{array}{l}\text { Fácil de controlar a } \\
\text { Administraçấo de Pessoal }\end{array}$ \\
\hline 15 & $\begin{array}{l}\text { Ter possibilidade de registrar } \\
\text { atendimentos ambulatoriais e } \\
\text { médicos. }\end{array}$ & Funcionárlos e professores & $\begin{array}{l}\text { Fácil de controtar a Medicina do } \\
\text { Trabalho }\end{array}$ \\
\hline 16 & $\begin{array}{l}\text { Ter possibilidade de fazer uma } \\
\text { triagem e seleçăo de candidatos a } \\
\text { partir do confronto dos requisitos } \\
\text { do cargo com o currículo dos } \\
\text { candidatos intemos e extemos }\end{array}$ & & $\begin{array}{l}\text { Fácil de controlar o } \\
\text { Recrutamento e Seleçăo }\end{array}$ \\
\hline 17 & $\begin{array}{l}\text { Ter possibilidade de registrar } \\
\text { horas normais trabalhadas, horas } \\
\text { extras, compensaços }\end{array}$ & Funclonários e professores & Fácil de controlar o Cartăo Ponto \\
\hline 18 & $\begin{array}{l}\text { Ter possibilidade de registrar os } \\
\text { requisitos e descriçóes de cargos, } \\
\text { de procedimentos operacionais, } \\
\text { estruturas salariais, propostas de } \\
\text { enquadramentos salariais } \theta \text { de } \\
\text { cargos }\end{array}$ & Funcionários e professores & $\begin{array}{l}\text { Fácil de controlar Cargos } \theta \\
\text { Salários }\end{array}$ \\
\hline 19 & $\begin{array}{l}\text { Ter possibilidade de cadastrar a } \\
\text { Ficha de Registro de Empregado } \\
\text { eletrónica }\end{array}$ & $\begin{array}{l}\text { Dados do cadastro do } \\
\text { empregado }\end{array}$ & $\begin{array}{l}\text { Fácil de registrar Ficha de } \\
\text { Empregado }\end{array}$ \\
\hline
\end{tabular}


Tabela 7.5 - Obtençāo dos Dados Originais - Recursos Humanos (continuação)

\begin{tabular}{|c|c|c|c|}
\hline $\mathbf{N}^{\circ}$ & DADOS ORIGINAIS & $\begin{array}{l}\text { DESDOBRAMENTO DA CENA } \\
\text { (quem, onde, quando, como, } \\
\text { por que) }\end{array}$ & REQUISITO DO CLIENTE \\
\hline 20 & $\begin{array}{l}\text { Ter possibilidade de fazer a } \\
\text { Contabilizaçáo da Provisäo e do } \\
\text { Pagamento }\end{array}$ & $\begin{array}{l}\text { Integraçăo de dados com a } \\
\text { Contabilidade }\end{array}$ & $\begin{array}{l}\text { Fácil de integrar os dados do RH } \\
\text { com a Contabilidade }\end{array}$ \\
\hline 21 & $\begin{array}{l}\text { Ter possibilidade de registrar } \\
\text { observaçes referentes às } \\
\text { alteraçōes realizadas no cálculo da } \\
\text { Folha de Pagamento }\end{array}$ & & $\begin{array}{l}\text { Gerar um Histórico sobre as } \\
\text { diversas alteraçōes efetuadas no } \\
\text { cálculo da Folha de Pagamento }\end{array}$ \\
\hline 22 & $\begin{array}{l}\text { Descrever o conhecimento } \\
\text { especifico exigido para a aplicaçäo } \\
\text { do sistema }\end{array}$ & Caixa do produto & $\begin{array}{l}\text { Ter conhecimento sobre o grau } \\
\text { mínimo de instruçăo necessário } \\
\text { para operar o sistema }\end{array}$ \\
\hline \multirow[t]{2}{*}{23} & \multirow[t]{2}{*}{ Deve ser fornecido treinamento } & \multirow[t]{2}{*}{ usar o sistema } & $\begin{array}{l}\text { Ter conhecimento se é oferecido } \\
\text { treinamento }\end{array}$ \\
\hline & & & Fácil de aprender a usar \\
\hline 24 & $\begin{array}{l}\text { Descrever se apresenta menus, } \\
\text { janelas, teclas de funçăo e de } \\
\text { auxilio }\end{array}$ & Caixa do produto & Fácil de saber o tipo de interface \\
\hline 25 & $\begin{array}{l}\text { Possibilitar mudanças de } \\
\text { parámetros, desde que essas } \\
\text { alteraçōes näo sejam muito técnicas }\end{array}$ & Cálculo da Folha de Pagamento & $\begin{array}{l}\text { Fácil de alterar parâmetros para } \\
\text { efetuar o cálculo da Folha de } \\
\text { Pagamento }\end{array}$ \\
\hline 26 & $\begin{array}{l}\text { Sistema deve ter um desempenho } \\
\text { adequado durante sua utilizaçäo }\end{array}$ & $\begin{array}{l}\text { Cálculo da Folha de Pagamento } \\
\text { e emissão de relatórios }\end{array}$ & $\begin{array}{l}\text { Ter conhecimento do tempo de } \\
\text { processamento e de execução dos } \\
\text { dados }\end{array}$ \\
\hline 27 & Ter uma rotina própria de backup & Sistema & $\begin{array}{l}\text { Fácil de gerar cópias de } \\
\text { segurança }\end{array}$ \\
\hline 28 & $\begin{array}{l}\text { Apresentar as mesmas funçōes que } \\
\text { foram descritas na caixa do produto }\end{array}$ & Manual do usuário & $\begin{array}{l}\text { Fácil de saber se as informaçōes } \\
\text { apresentadas no manual do } \\
\text { usuário são as mesmas } \\
\text { apresentadas na caixa do produto }\end{array}$ \\
\hline 29 & $\begin{array}{l}\text { Ter f́ndice ou sumário para } \\
\text { visualizaçăo geral das informaçōes }\end{array}$ & Manual do usuário & $\begin{array}{l}\text { Ter Índice para facilitar acesso } \\
\text { geral às informaçōes }\end{array}$ \\
\hline \multirow[t]{2}{*}{30} & \multirow{2}{*}{$\begin{array}{l}\text { Apresentar as telas em modo } \\
\text { gráfico com uma breve explicação } \\
\text { com exemplos }\end{array}$} & \multirow[t]{2}{*}{ Manual do usuário } & Fácil de visualizar as telas \\
\hline & & & $\begin{array}{l}\text { Fácil de entender as explicaçóes } \\
\text { das telas com exemplos }\end{array}$ \\
\hline 31 & Mostrar exemplos dos relatórios & Manual do usuário & $\begin{array}{l}\text { Fácil de entender os exemplos de } \\
\text { saida dos dados (relatórios) }\end{array}$ \\
\hline 32 & $\begin{array}{l}\text { As informações devem ser corretas } \\
\text { e sem ambigüidades }\end{array}$ & Manual do usuário & $\begin{array}{l}\text { Apresentar as informaçōes } \\
\text { corretas e sem ambigüidades }\end{array}$ \\
\hline 33 & $\begin{array}{l}\text { A linguagem utilizada deve ser } \\
\text { acessivel } \theta \text { evitar termos técnlcos }\end{array}$ & Manual do usuário & $\begin{array}{l}\text { Entender facilmente a linguagem } \\
\text { utilizada }\end{array}$ \\
\hline 34 & $\begin{array}{l}\text { As informaçöes devem ser } \\
\text { coerentes }\end{array}$ & Pacote e manual do usuário & $\begin{array}{l}\text { Ter coerêncla das informaçöes } \\
\text { contidas no manual do usuário } \\
\text { com as informaçōes contidas na } \\
\text { descriçāo da caixa }\end{array}$ \\
\hline 35 & $\begin{array}{l}\text { Ter consistência de vocabulário } \\
\text { entre as mensagens }\end{array}$ & $\begin{array}{l}\text { Dos programas e o manual do } \\
\text { usuário }\end{array}$ & $\begin{array}{l}\text { Ter consistência de vocabulário } \\
\text { entre as mensagens dos } \\
\text { programas } \theta \text { o manual do usuário }\end{array}$ \\
\hline 36 & $\begin{array}{l}\text { As mensagens, os formatos de tela } \\
\text { de entrada de dados e os relatórios } \\
\text { devem estar estruturados de } \\
\text { maneira uniforme }\end{array}$ & Uso do pacote & $\begin{array}{l}\text { Ter controle da operação e do } \\
\text { comportamento do programa }\end{array}$ \\
\hline 37 & $\begin{array}{l}\text { Ter garantia dos dados mesmo } \\
\text { quando informar dados fora dos } \\
\text { limites especificados }\end{array}$ & Uso do pacote & $\begin{array}{l}\text { Ter controle do estado anormal } \\
\text { sem perdr os dados }\end{array}$ \\
\hline 38 & $\begin{array}{l}\text { As mensagens na tela devem ser } \\
\text { claras }\end{array}$ & Uso do pacote & $\begin{array}{l}\text { Diferenciar mensagens de } \\
\text { confirmaçāo, consulta, advertência }\end{array}$ \\
\hline
\end{tabular}


Tabela 7.5 - Obtenção dos Dados Originais - Recursos Humanos (continuação)

\begin{tabular}{|c|l|l|l|}
\hline $\mathbf{N}^{\circ}$ & \multicolumn{1}{|c|}{ DADOS ORIGINAIS } & $\begin{array}{l}\text { DESDOBRAMENTO DA CENA } \\
\text { (quem, onde, quando, como, } \\
\text { por que) }\end{array}$ & REQUISITO DO CLIENTE \\
\hline 39 & $\begin{array}{l}\text { O formato das telas e de relatórios } \\
\text { devem ser claros }\end{array}$ & Uso do pacote & $\begin{array}{l}\text { Fácil de entender as telas e } \\
\text { relatórios }\end{array}$ \\
\hline 40 & $\begin{array}{l}\text { Ter mensagens de alerta quando } \\
\text { for excluir ou sobrepor alguma } \\
\text { informação }\end{array}$ & Uso do pacote & $\begin{array}{l}\text { Ter mensagens de alerta quando } \\
\text { for excluir ou sobrepor alguma } \\
\text { informaçăo }\end{array}$ \\
\hline 41 & $\begin{array}{l}\text { Ter um menu mostrando as } \\
\text { principais funcóes do pacote }\end{array}$ & Uso do pacote & $\begin{array}{l}\text { Ter um menu mostrando as } \\
\text { principais funçóes do pacote }\end{array}$ \\
\hline 42 & Ter teclas de auxilio para cada tela & Uso do pacote & $\begin{array}{l}\text { Ter teclas de aux́lio para cada } \\
\text { tela }\end{array}$ \\
\hline
\end{tabular}


Tabela 7.6 - Tabela de Desdobramento dos Requisitos do Cliente - Recursos Humanos

\begin{tabular}{|c|c|c|}
\hline $1^{\circ}$ Nivel & $2^{\circ}$ Nivel & $\begin{array}{c}\text { Grau de } \\
\text { Importância }\end{array}$ \\
\hline \multirow[t]{3}{*}{ 1. Aparência agradável } & 1.1 Visual bonito & \\
\hline & 1.2 Ser fácil de ier as informaçōes & \\
\hline & 1.3 Ser fácil de entender as informaçōes & \\
\hline \multirow[t]{4}{*}{ 2. Fácil de |dentfflcar } & 2.1 A caixa do produto & \\
\hline & 2.20 nome, versăo e fornecedor & \\
\hline & 2.3 o conteúdo da émbalagem & \\
\hline & 2.4 As principais características & \\
\hline \multirow{12}{*}{$\begin{array}{l}\text { 3. Fácil de saber se as } \\
\text { informações estão } \\
\text { declaradas }\end{array}$} & 3.1 Referência a documentos de requisitos & \\
\hline & 3.2 o tipo de piataforma necessária & \\
\hline & 3.3 integraçőes com outros móduios & \\
\hline & 3.40 responsávei peia instaiaçāo & \\
\hline & 3.5 Ter contrato de manutenção & \\
\hline & 3.6 Fácil de ser instalado ern outro equipamento & \\
\hline & 3.7 Ter contrato de assistência & \\
\hline & 3.80 grau de conhecimento mínimo exigido & \\
\hline & 3.9 Apresentar o tempo de resposta e de execucão dos dados & \\
\hline & 3.10 Fácil de gerar cópias de segurança dos dados (backup) & \\
\hline & 3.11 Fácil de saber o tipo de interface & \\
\hline & 3.12 Ter indicação de treinamento & \\
\hline \multirow{2}{*}{$\begin{array}{l}\text { 4. Fácil de registrar } \\
\text { informaçöes }\end{array}$} & 4.1 Fácil de registrar Ficha de Empregado & \\
\hline & $\begin{array}{l}\text { 4.2 Fácil de gerar histónico das alteraçóes efetuadas no cáiculo da Foiha } \\
\text { de Pagamento }\end{array}$ & \\
\hline \multirow{5}{*}{$\begin{array}{l}\text { 5. Fácil de controlar } \\
\text { informações }\end{array}$} & 5.1 Fácil de controiar a administração de pessoal & \\
\hline & 5.2 Fácil de controlar a medicina do trabalho & \\
\hline & 5.3 Fácil de controiar o recrutamento e seleção & \\
\hline & 5.4 Fácil de controlar o cartão ponto & \\
\hline & 5.5 Fácil de controlar cargos e salários & \\
\hline \multirow{2}{*}{$\begin{array}{l}\text { 6. Ser ambiente multi- } \\
\text { usuário }\end{array}$} & 6.1 Possibilitar trabalhar em rede & \\
\hline & 6.2 Abrir várias janelas $\theta$ trabalhar em paralelo & \\
\hline \multirow{6}{*}{$\begin{array}{l}\text { 7. Entender facilmente o } \\
\text { manual do usuário }\end{array}$} & 7.1 Apresentar as informaçōes corretas e sem ambigüidades & \\
\hline & 7.2 Entender facilmente a linguagem utilizada & \\
\hline & 7.3 Ter indice para facilitar acesso geral às informações & \\
\hline & 7.4 Ser fácil de visualizar as telas & \\
\hline & 7.5 Ser fácil de entender as explicaçőes das telas com exemplos & \\
\hline & 7.6 Ser fácil de entender os exempios de saida dos dados (relatórios) & \\
\hline 8. Ser completo & $\begin{array}{l}\text { 8.1 Manual do usuário deve apresentar as mesmas funções que foram } \\
\text { declaradas na caixa do produto }\end{array}$ & \\
\hline \multirow[t]{2}{*}{$\begin{array}{l}\text { 9. Ter consistência das } \\
\text { informações }\end{array}$} & $\begin{array}{l}\text { 9.1 Possuir coerēncia das informaçōes contidas no manual do usuário } \\
\text { com as informaçoes contidas na descrição da caixa do produto }\end{array}$ & \\
\hline & $\begin{array}{l}\text { 9.2 Ter consistência de vocabulário entre as mensagens dos programas e } \\
\text { o manual do usuário }\end{array}$ & \\
\hline \multirow[t]{12}{*}{ 10. Fácil de usar } & 10.1 Fácil manuseio das entradas e saidas & \\
\hline & $\begin{array}{l}10.2 \text { Ter controle da operação e do comportamento do programa em } \\
\text { execuçäo }\end{array}$ & \\
\hline & 10.3 Ter controte do estado anormal sem perder os dados & \\
\hline & $\begin{array}{l}10.4 \text { Ser possivel diferenciar mensagens de confirmação, da consulta, de } \\
\text { advertência e de efro }\end{array}$ & \\
\hline & 10.5 Ter um menu mostrando as principais funcöes & \\
\hline & 10.6 Fácil de entender as telas e relatórios & \\
\hline & $\begin{array}{l}\text { 10.7 Ter mensagens de aierta quando for excluir ou sobrepor aiguma } \\
\text { informaçầo }\end{array}$ & \\
\hline & 10.8 Ter tectas de auxilio para cada tela & \\
\hline & 10.9 Fácil de alterar parametros para o cáiculo da Folha de Pagamento & \\
\hline & 10.10 Fácil de integrar dados do RH com a Contabilidade & \\
\hline & 10.11 Ser fácil de aprender a usar & \\
\hline & 10.12 Ser fácil de usar & \\
\hline
\end{tabular}


- Ciclo de Determinação de Importância das Características do Pacote

Para auxiliar a condução da sessão de entrevista estruturada, realizada com os membros da sessão, foi elaborado um plano (Quadro 7.7).

O plano foi colocado em prática, preenchendo-se a terceira coluna com o grau de importância de cada uma das características do Pacote (Tabela 7.7).

As prionidades das características do pacote foram validadas junto ao cliente.

Quadro 7.7 - Estrutura do Plano para a Sessão de Entrevlsta Estruturada - Recursos Humanos

\section{PLANO PARA A SESSÃO DE ENTREVISTA ESTRUTURADA}

1 Introdução: o objetivo deste plano é orientar o Engenheiro de Conhecimento a conduzir uma sessão de entrevisto estruturada.

\section{Gerenciamento}

Local de Sessão: Setor de Recursos Humanos

Data da Sessão: 16/02/2000 Horário: 9:45

Tempo Total: 0:35

Engenheiro de Conhecimento: Jusane Farina Lara

Entrevistado/Fonte de Conhecimento: Juliana Malvesso Lima

Meta da Sessão: questionar sobre o grau de importância de cada uma das características do Pacote identificadas no ciclo anterior.

\section{Tarefos:}

3.4 Deve ser exposto ao entrevistado a importância de suas informações.

3.5 Apresentar a Tabeia de Desdobramento dos Requisitos do Cliente (TDRC) e questionar o Cliente quanto à prioridade.

3.6 A escala de valores possíveis para o grau de importância deve ser de um (1) a cinco (5). O valor um (1) corresponde a nenhumo importância, o valor dois (2) corresponde a pouca importância, o valor três (3) corresponde a alguma importância, o valor quatro (4) corresponde a importante e o valor cinco (5) corresponde a muito importante.

4 Cronograma: O entrevistado deve gastar 30 minutos para responder as questöes.

5 Recursos: o local selecionado para a entrevista deve ser isolado de quaisquer outras pessoas que não façam parte da sessão, para que não haja interferência na lógica de raciocínio do Cliente. 
Tabela 7.7 - Tabela de Desdobramento dos Requisitos do Cliente com o Grau de Importáncia - Recursos Humanos

\begin{tabular}{|c|c|c|}
\hline $1^{\circ}$ Nivel & $2^{\circ}$ Nivel & $\begin{array}{c}\text { Grau de } \\
\text { Importância' }\end{array}$ \\
\hline \multirow[t]{3}{*}{ 1. Aparência agradável } & 1.1 Visual bonito & 4 \\
\hline & 1.2 Ser fácil de ler as informacōes & 4 \\
\hline & 1.3 Ser fácil de entender as informacōes & 4 \\
\hline \multirow[t]{4}{*}{ 2. Fácil de ídentificar } & 2.1 A caixa do produto & 4 \\
\hline & 2.20 nome, versão e fornecedor & 4 \\
\hline & 2.30 conteúdo da ernbalagem & 4 \\
\hline & 2.4As principais caracteristicas & 5 \\
\hline \multirow{12}{*}{$\begin{array}{l}\text { 3. Fácil de saber se as } \\
\text { informaçōes estāo } \\
\text { deciaradas }\end{array}$} & 3.1 Referência a documentos de requisitos & 3 \\
\hline & 3.20 tipo de plataforma necessária & 5 \\
\hline & 3.3 Integraçōes com outros módulos & 5 \\
\hline & 3.40 responsável pela instalaçåo & 3 \\
\hline & 3.5 Ter contrato de manutença & 5 \\
\hline & 3.6 Fácil de ser instalado em outro equipamento & 3 \\
\hline & 3.7 Ter contrato de assistência & 5 \\
\hline & 3.80 grau de conhecimento minimo exigido & 4 \\
\hline & 3.9 Apresentar o tempo de resposta e de execução dos dados & 3 \\
\hline & 3.10 Fácii de gerar cópias de segurança dos dados (backup) & 5 \\
\hline & 3.11 Fácil de saber o tipo de interface & 4 \\
\hline & 3.12 Ter indicaçao de treinamento & 5 \\
\hline \multirow{2}{*}{$\begin{array}{l}\text { 4. Fácil de registrar } \\
\text { informaçōes }\end{array}$} & 4.1 Fácil de registrar Ficha de Empregado & 3 \\
\hline & $\begin{array}{l}\text { 4.2 Fácil de gerar histórico das aiteraçöes efetuadas no cálculo da Folha } \\
\text { de Pagamento }\end{array}$ & 4 \\
\hline \multirow{5}{*}{$\begin{array}{l}\text { 5. Fácil de controlar } \\
\text { informaçōes }\end{array}$} & 5.1 Fácil de controlar a administraçăo de pessoal & 5 \\
\hline & 5.2 Fácil de controlar a medicina do trabalho & 4 \\
\hline & 5.3 Fácll de controlar o recrutamento e seleçāo & 2 \\
\hline & 5.4Fácil de controlar o cartāo ponto & 5 \\
\hline & 5.5 Fácil de controlar cargos e salários & 4 \\
\hline \multirow{2}{*}{$\begin{array}{l}\text { 6. Ser ambiente multi- } \\
\text { usuário }\end{array}$} & 6.1 Possibilitar trabalhar em rede & 4 \\
\hline & 6.2 Abrir várias janelas e trabalhar em paraleio & 4 \\
\hline \multirow{6}{*}{$\begin{array}{l}\text { 7. Entender facilmente o } \\
\text { manual do usuário }\end{array}$} & 7.1 Apresentar as informaçōes corretas e sem ambiguidades & 4 \\
\hline & 7.2 Entender facilmente a linguagem utilizada & 4 \\
\hline & 7.3 Ter indice para facilitar acesso geral às informacöes & 4 \\
\hline & 7.4 Ser fácil de visualizar as telas & 4 \\
\hline & 7.5 Ser fácii de entender as explicaçōes das telas com exemplos & 4 \\
\hline & 7.6 Ser fácil de entender os exemplos de saída dos dados (relatórios) & 3 \\
\hline 8. Ser completo & $\begin{array}{l}\text { 8.1 Manual do usuário deve apresentar as mesmas funçōes que foram } \\
\text { declaradas na caixa do produto }\end{array}$ & $\overline{5}$ \\
\hline \multirow[t]{2}{*}{$\begin{array}{l}\text { 9. Ter consistência das } \\
\text { informaçőes }\end{array}$} & $\begin{array}{l}\text { 9.1 Possuir coerência das informaçōes contidas no manual do usuário } \\
\text { com as informaçoos contidas na descricẳo da caixa do produto }\end{array}$ & 4 \\
\hline & $\begin{array}{l}\text { 9.2 Ter consistência de vocabulário entre as mensagens dos programas e } \\
\text { o manuai do usuánio }\end{array}$ & 4 \\
\hline \multirow[t]{12}{*}{ 10. Fácil de usar } & 10.1 Fácil manuseio das entradas e saídas & 4 \\
\hline & $\begin{array}{l}10.2 \text { Ter controle da operaçāo e do comportamento do programa em } \\
\text { execuçáo }\end{array}$ & $\overline{3}$ \\
\hline & 10.3 Ter controle do estado anormal sem perder os dados & 3 \\
\hline & $\begin{array}{l}\text { 10.4 Ser possivel diferenciar mensagens de confirmaçăo, de consulta, de } \\
\text { advertência e de erro }\end{array}$ & 3 \\
\hline & 10.5 Ter um menu mostrando as principais funcōes & 4 \\
\hline & 10.6 Fácil de entender as telas e relatónios & 3 \\
\hline & $\begin{array}{l}10.7 \text { Ter mensagens de alerta quando for excluir ou sobrepor alguma } \\
\text { informação }\end{array}$ & 4 \\
\hline & 10.8 Ter tecias de auxilio para cada tela & 4 \\
\hline & 10.9 Fácil de alterar paråmetros para o cálculo da Folha de Pagamento & 5 \\
\hline & 10.10 Fácii de integrar dados do RH com a Contabilidade & 5 \\
\hline & 10.11 Ser fácil de aprender a usar & 5 \\
\hline & 10.12 ser fácil de usar & 5 \\
\hline
\end{tabular}

\footnotetext{
1 Escala de Likert: 1 - nenhuma importância 2 - pouca importância 3 -alguma importância 4 -importante 5 muito importante
} 
- Construção da Matriz Casa da Qualidade

Para construção da matriz Casa da Qualidade utilizou-se a ferramenta QFDT (Quality Function Deployment Tool) descrita no Apêndice A.

A tabela de desdobramento dos requisitos do cliente produzida pelo processo de aquisição de conhecimento IPAIA, instanciado para o domínio QFD - Casa da Qualidade, determinaram as "linhas" da matriz Casa da Qualidade. As informaçöes contidas na Tabela 7.7 que correspondem aos desdobramentos dos requisitos do cliente e ao grau de importância, foram transcritas para o lado esquerdo da matriz (Figura 7.2). Nas "colunas" da matriz foram colocadas as características de qualidade para pacote de software. Em seguida, realizou-se a correlação entre os requisitos do cliente com as caracteristicas de pacote de software, conforme o procedimento descrito na seção 5.3 do Capítulo 5 . Finalmente, a ferramenta QFDT gerou o grau de importância das características de pacote apresentadas na última linha da matriz da Figura 7.2.

Em função do formato de apresentação, a ferramenta QFDT fez uma pequena modificação no modo de cálculo do grau de importância (última linha da matriz da Figura 7.2), - que não altera o percentual final de cada característica do pacote de software. A alteração está relatada no Quadro 7.8.

Quadro 7.8 - Procedimento para obter o Grau de Importância das Características de Pacote

a) Obter a antepenúltima linha da matriz Casa da Qualidade como apresentada na seção 5.3 do Capítulo 5.

b) Realizar o somatório da coluna "grau de importância dos requisitos do cliente".

c) Realizar o somatório da linha "grau de importância das características de pacote" obtido no item a).

d) Calcular a proporção, dividindo o valor obtido no item b) pelo valor obtido no item c).

e) Multiplicar a proporção obtida no item d) por cada valor da linha do item a). 


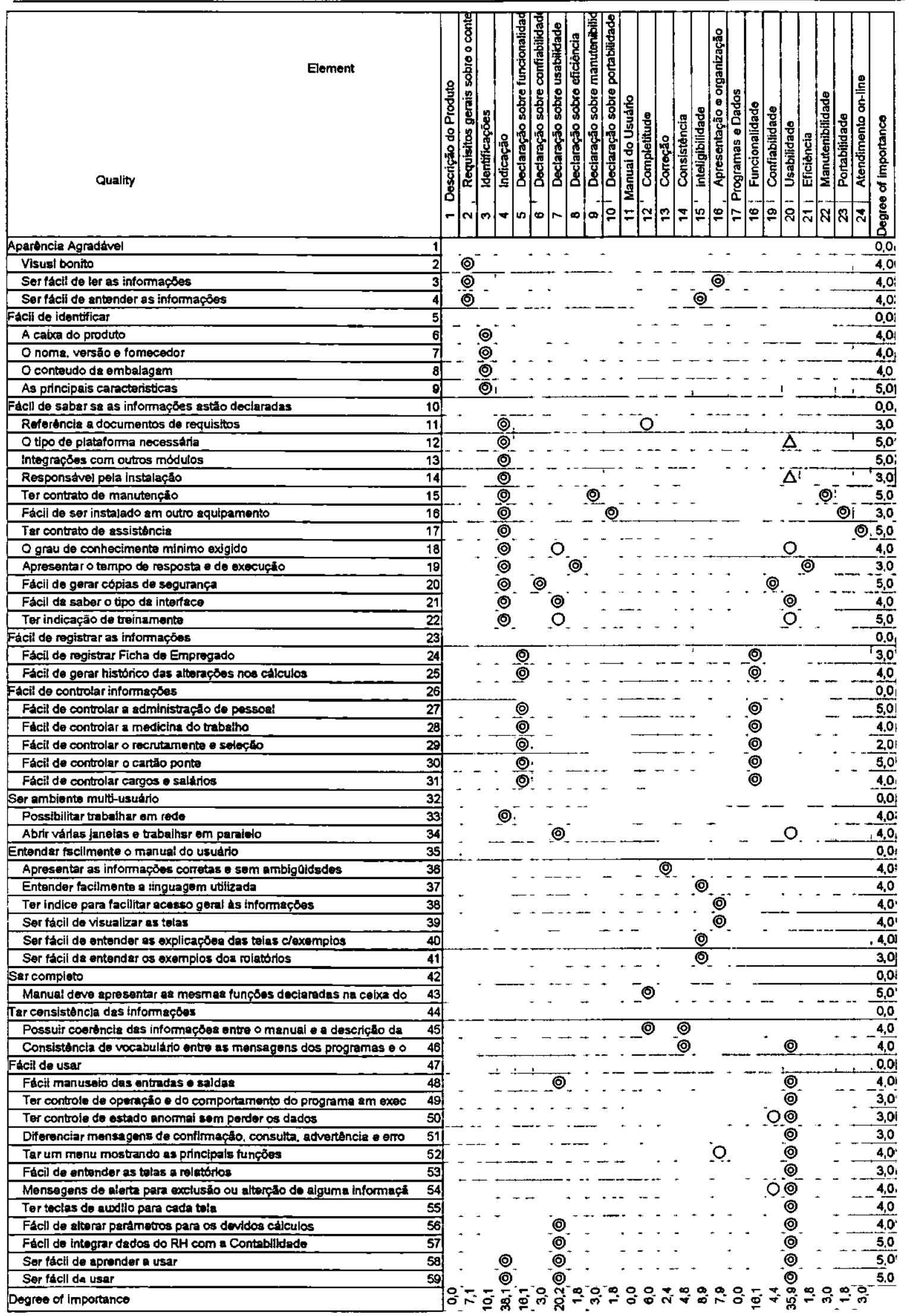

Figura 7.2 - Matriz Casa da Qualidade - Recursos Humanos 
Para realizar a geração do grau de importância das características de pacote, deve-se converter os valores do grau de importância (última linha da matriz da Figura 7.2) em valores percentuais. Para isso, deve-se seguir os passos descritos abaixo:

a) Transcrever os valores da última linha da matriz da Figura 7.2 para as colunas correspondentes da matriz da Tabela 7.8;

b) Realizar o somatóno para os valores das colunas correspondentes a cada característica de pacote: descrição do produto, manual do usuánio e programas $\theta$ dados da Tabela 7.8. Transcrever o resultado para as colunas correspondentes da Tabela 7.8;

c) Realizar o somatónio dos valores obtidos no item b). Transcrever o resultado para a célula " $\sum$ Grau de Importância das Características de Pacote";

d) Transformar os valores obtidos na penúltima linha da Tabela 7.8 na base $100 \%$. Transcrever os resultados para a última linha da matriz da Tabela 7.8 nas colunas corresponderites.

Tabela 7.8 - Geraçăo do Grau de Importancia em Percentagem - Recursos Humanos

\begin{tabular}{|c|c|c|c|c|c|c|c|c|c|c|c|c|c|c|c|c|c|c|c|c|}
\hline \multirow{3}{*}{ Requisitos do Cliente } & \multirow{3}{*}{ 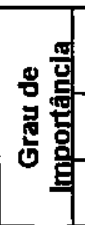 } & \multicolumn{19}{|c|}{ Características de Pacote de Software } \\
\hline & & \multicolumn{9}{|c|}{ Descrição do Produto } & \multicolumn{4}{|c|}{$\begin{array}{l}\text { Manual do } \\
\text { Usuário }\end{array}$} & \multicolumn{6}{|c|}{ Programas \& Dados } \\
\hline & & & & & & & & & & & & & & & & & & & & \\
\hline & & & & & & & & & & & & & & & & & & & & \\
\hline & & & & & & & & & & & & & & & & & & & & \\
\hline & & & & & & & & & & & & & & & & & & & & \\
\hline $\begin{array}{l}\text { Grau de Importância das } \\
\text { Características de Pacote }\end{array}$ & & $\bar{N}$ & 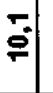 & $\bar{\phi}$ & $\bar{q}^{-}$ & : & กั. & $\stackrel{\infty}{-}$ & 요 & $\stackrel{\infty}{-}$ & : & \pm & $\stackrel{\infty}{\rightarrow} \underset{\infty}{\infty}$ & $\stackrel{9}{n}$ & $\bar{\varphi}$ & + & cos & $\stackrel{\infty}{=}$ i & $\stackrel{\infty}{-}$ & 울 \\
\hline $\begin{array}{l}\sum \text { Grau de Importância das } \\
\text { Características de Pacote } \\
197,20\end{array}$ & & & & & & 1,2 & & & & & & & 10,0 & & & & & 36,0 & & \\
\hline Necessidades do Cliente (\%) & & & & & & 1,32 & & & & & & & 5,21 & & & & & 3,47 & & \\
\hline
\end{tabular}




\subsection{2 - Avaliação do Pacote de Software - Recursos Humanos}

A Universidade do Oeste de Santa Catarina possui um Sistema de Recursos Humanos denominado Vetorh. Esse sistema foi adquirido da empresa Senior Sistemas, localizada na cidade de Blumenau (SC), através do seu representante local de software, CBA Informática Ltda. Atualmente, o sistema roda em ambiente DOS, mas a instituição está migrando para uma nova versăo em ambiente Windows. O Vetorh é um completo sistema de administração de pessoal, que permite o controle dos colaboradores em todos os estágios, legais ou gerenciais, abrangendo todo o departamento de pessoal, tratando desde a admissão, transporte, férias, folha de pagamento até a rescisão contratual. Este sistema também administra e automatiza a apuração da freqüência, ou seja, o cartão ponto.

Para a avaliação do pacote de software Vetorh analisou-se a descrição do produto apresentada na embalagem do produto, o manual do usuário que acompanha a caixa e a avaliação do pacote através da utilização do sistema. O engenheiro de conhecimento responsável pela avaliação foi a própria autora deste trabalho de mestrado.

O pacote de software Vetorh foi avaliado aplicando-se as métricas definidas no Capítulo 6.

Para medição, os questionários do Quadro 7.9 foram respondidos considerando-se o pacote de software Vetorh.

Primeiramente, somou-se as notas das respostas das caracteristicas de qualidade obtendo-se a nota de cada requisito de qualidade.

Posteriormente, contou-se a quantidade de questões existentes para cada requisito de qualidade. Para o requisito de qualidade descrição do produto tem-se 23 questões que multiplicado por dois (2) que é a nota máxima obtida para cada resposta, obteve-se 46 para a nota máxima. Para os demais requisitos de qualidade repetiu-se o mesmo procedimento.

Finalmente, converteu-se a nota de cada requisito de qualidade em valor percentual. Para isso, dividiu-se o valor de cada célula correspondente a nota pela nota máxima e multiplicou-se por 100. Para o requisito de qualidade descrição do produto, dividiu-se a nota cujo valor é 25 pela nota máxima cujo valor é 46, multiplicado por 100 , obteve-se o resultado $54 \%$. Para os demais requisitos de qualidade repetiu-se o mesmo procedimento. 
Quadro 7.9 - Avaliação do Pacote de Software - Recursos Humanos

\begin{tabular}{|c|c|}
\hline \multicolumn{2}{|l|}{$\begin{array}{l}\text { REQUISITO DE QUALIDADE: DESCRIÇĀO DO PRODUTO } \\
\text { Nota }=25\end{array}$} \\
\hline MEDIDAS & RESPOSTAS \\
\hline \multicolumn{2}{|c|}{ Característica de Qualidade: Requisitos Gerais sobre o conteúdo da descrição do produto } \\
\hline $\begin{array}{l}\text { 1. O conteúdo da descrição do produto está inteligivel, completo e } \\
\text { possui boa organizaçăo e apresentaçăo? }\end{array}$ & $\begin{array}{ll}\text { O.V Nẫo. A descriçāo está muito técnica } \\
\text { 1. Algumas partes estāo dificels de compreender } \\
\text { 2. Sim. Geralmente } \\
\end{array}$ \\
\hline \multicolumn{2}{|l|}{ Caracteristica de Qualidade: Identificaçăo } \\
\hline $\begin{array}{l}\text { 2. O documento da descriçăo do produto possui uma única } \\
\text { identificaçāo? }\end{array}$ & $\begin{array}{ll}0 . & \text { Nåo } \\
2 . \checkmark & \text { Sim }\end{array}$ \\
\hline $\begin{array}{l}\text { 3. A identificação do produto possui o nome do produto e uma } \\
\text { versăo ou data? }\end{array}$ & $\begin{array}{ll}0 . & \text { Năo } \\
2 . \checkmark \mathrm{Sim}\end{array}$ \\
\hline $\begin{array}{l}\text { 4. A Identificação do fornecedor contém o nome e o endereço de, } \\
\text { no minimo, um fornecedor? }\end{array}$ & $\begin{array}{ll}0 . & \text { Näo } \\
2 . & \text { Sim }\end{array}$ \\
\hline $\begin{array}{l}\text { 5. Existe indicaçäo das tarefas que podem ser realizadas utillzando } \\
\text { o produto? }\end{array}$ & $\begin{array}{ll}\text { Năo } \\
\text { 2. Sim }\end{array}$ \\
\hline $\begin{array}{c}\text { 6. A descriçāo do produto faz referência aos documentos de } \\
\text { requisitos com os quais o produto está em conformidade? }\end{array}$ & $\begin{array}{l}\text { 0. Não } \\
\text { 1. Faz referèncla apenas para alguns documentos } \\
\text { 2. Sim } \\
\end{array}$ \\
\hline \multicolumn{2}{|l|}{ Característica de Qualidade: Indicaçāo } \\
\hline $\begin{array}{l}\text { Existe indicaçāo dos requisitos de hardware e software para } \\
\text { colocar o produto em uso, ou seja, nomes de fabricantes e } \\
\text { Identificaçăo do tipo de todos os componentes? }\end{array}$ & $\begin{array}{l}\text { 0. Năo } \\
\text { 1. Alguns requlsitos estão identificados, não todos } \\
\text { 2. } \quad \text { Sim. Todos os requisitos estão identificados }\end{array}$ \\
\hline $\begin{array}{l}\text { 8. Se a descriçäo do produto faz referênclas a interfaces com } \\
\text { outros produtos, essas interfaces ou produtos estão } \\
\text { ldentlficados? }\end{array}$ & \begin{tabular}{|l|l|} 
0. Não \\
1. Algumas interfaces ou produtos estão identificados \\
2.r Sim. Todas as interfaces ou produto estăo \\
identlficados
\end{tabular} \\
\hline $\begin{array}{l}\text { 9. Todo componente fisico do produto fornecido está identificado, } \\
\text { Incluindo todos os documentos impressos e todos os meios de } \\
\text { armazenamento? }\end{array}$ & 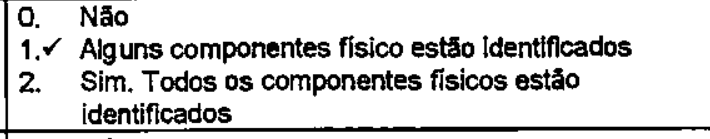 \\
\hline $\begin{array}{l}\text { 10. A descrição do produto fornece uma declaraçã̃o indlcando se a } \\
\text { instalaçăo do produto é oferecida ou năo? }\end{array}$ & $\begin{array}{ll}0 . & \text { Năo } \\
2 . \checkmark & \text { SIm }\end{array}$ \\
\hline $\begin{array}{l}\text { 11. A descrlção do produto fornece uma declaraçăo indicando se a } \\
\text { manutenção do produto é oferecida ou năo? }\end{array}$ & $\begin{array}{l}\text { 0. Nåo } \\
\text { 2. S Sirn }\end{array}$ \\
\hline \multicolumn{2}{|l|}{ Característica de Quaiidade: Declaração sobre Funcionalidade } \\
\hline $\begin{array}{l}\text { 12. A descriçăo do produto fornece urna visão geral das funçōes } \\
\text { dlsponiveis para o usuário do produto, os dados necessários e } \\
\text { as facilidades oferecidas? }\end{array}$ & $\begin{array}{l}\text { Năo } \\
\text { 1. Apresenta algumas funçöes disponiveis, nåo todas } \\
\text { 2. Sim. Apresenta todas as funçōes disponiveis }\end{array}$ \\
\hline $\begin{array}{l}\text { 13. Os valores limite são especificados para todos os dados de } \\
\text { entrada que deverăo ser testados? }\end{array}$ & \begin{tabular}{|l|l|}
0. & Não \\
1. $\checkmark$ Apresenta alguns valores limite \\
2. Sim. Apresenta todos os valores limite \\
\end{tabular} \\
\hline $\begin{array}{l}\text { 14. A descrição do produto Inclui Informaçoes a respeito de } \\
\text { maneiras, se fornecidas, para evitar o acesso năo autorizado } \\
\text { (acidental ou intencional) a programas e dados? }\end{array}$ & $\begin{array}{l}\text { 0.V Nåa } \\
\text { 1. Apresenta algumas informaçōes } \\
\text { 2. Sim. Apresenta todas as informaçōes }\end{array}$ \\
\hline
\end{tabular}


Quadro 7.9 - Avaliação do Pacote de Software - Recursos Humanos (continuação)

\begin{tabular}{|c|c|}
\hline REQUISITO DE QUALIDADE: DESCRIÇĀO DO PRODUTO & ... \\
\hline MEDIDAS & RESPOSTAS \\
\hline \multicolumn{2}{|l|}{ Característica de Qualidade: Declaração sobre Confiabilidade } \\
\hline $\begin{array}{l}\text { 15. Existe uma declaraçáa dizendo como se deve fazer backup } \\
\text { (através do Sistema Operacional ou de um comando especiflco } \\
\text { contido no software produto)? }\end{array}$ & $\begin{array}{l}\text { 0. Näo } \\
2 . \quad \text { Sim }\end{array}$ \\
\hline $\begin{array}{l}\text { 16. É possivei reverter funçōes de efelto drástico decorrentes de erro } \\
\text { de usuário? }\end{array}$ & $\begin{array}{|ll|}0 . & \text { Näo } \\
1 . & \text { As vezzes, nāo sempre } \\
2 . & \text { Sim. Geraimente } \\
\end{array}$ \\
\hline \multicolumn{2}{|c|}{ Característica de Qualidade: Declaração sobre Usabilidade } \\
\hline $\begin{array}{l}\text { 17. O tipo de interface com o usuário está especificado na descriçăo } \\
\text { do produto, por exemplo, menu, janelas, teclas de funçăo, função } \\
\text { de help? }\end{array}$ & $\begin{array}{l}\text { 0. Näo } \\
\text { 1. Alguns tipos de interfaces estäo especificados } \\
\text { 2.V Sim. Todos os tipos de interfaces estāo } \\
\text { especificados }\end{array}$ \\
\hline $\begin{array}{l}\text { 18. Se é necessário conhecimento especifico para a aplicaçăo do } \\
\text { produto, este conhecimento especifico exigido está descrito na } \\
\text { descrição do produto? }\end{array}$ & $\begin{array}{ll}0 . \checkmark & \text { Não } \\
2 . & \operatorname{Sim}\end{array}$ \\
\hline $\begin{array}{l}\text { 19. Se o produto pode ser adaptado pelo usuárlo, entāo as } \\
\text { ferramentas para essa adaptaçăo e as condiçōes para seu uso } \\
\text { estāo identificadas? (exemplos: mudança de parâmetros, } \\
\text { mudança de algoritmos para computaçāo e atribuição de teclas } \\
\text { de funçăo). }\end{array}$ & 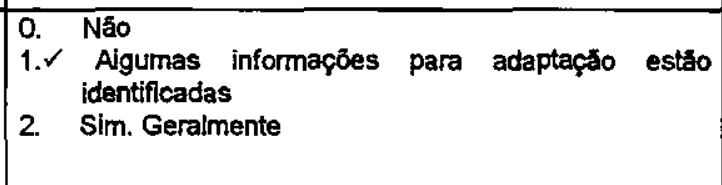 \\
\hline $\begin{array}{l}\text { 20. Se a proteçāo técnica contra infraçōes a direltos autorais pode } \\
\text { dificultar a usabilidade, entăo essa proteçăo está declarada? } \\
\text { (exemplos: proteçāo técnica contra cópias, datas programadas } \\
\text { de expiraçāo de uso, lembretes interativos para pagamento por } \\
\text { cópia) }\end{array}$ & $\begin{array}{ll}\text { O.V } & \text { Não } \\
1 . & \text { Aigumas informaçōes estäo declaradas } \\
2 . & \text { Sim. Geralmente }\end{array}$ \\
\hline \multicolumn{2}{|l|}{ Característica de Qualidade: Declaração sobre Eficiência } \\
\hline $\begin{array}{l}\text { 21. A descrição do produto possui dados sobre o comportamento do } \\
\text { produto em relação ao tempo, tais como tempo de resposta e de } \\
\text { processamento e a velocidade de execuçāo? }\end{array}$ & $\begin{array}{ll}0 . \checkmark & \text { Năo } \\
2 . & \text { Sim }\end{array}$ \\
\hline \multicolumn{2}{|l|}{ Característica de Qualidade: Declaraçäo sobre Manutenibilldade } \\
\hline $\begin{array}{l}\text { 22. A descrição do produto contém declaraçōes que evidenciam o } \\
\text { esforço necessário para fazer modificaçōes especificadas no } \\
\text { software? }\end{array}$ & $\begin{array}{ll}0 . \checkmark & \text { Năo } \\
2 . & \text { Sim }\end{array}$ \\
\hline \multicolumn{2}{|l|}{ Característica de Qualidade: Declaraçäo sobre Portabilidade } \\
\hline $\begin{array}{l}\text { 23. A descrição do produto contém declaraçōes que evidenciam a } \\
\text { capacidade do software ser transferido de um ambiente para } \\
\text { outro? }\end{array}$ & $\begin{array}{ll}\text { 0.V Não } \\
2 . & \text { Sim }\end{array}$ \\
\hline
\end{tabular}


Quadro 7.9 - Avaliação do Pacote de Software - Recursos Humanos (continuação)

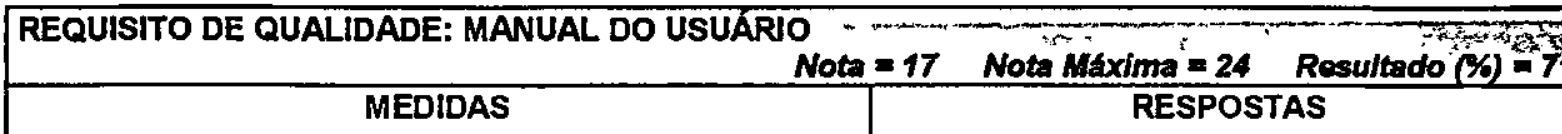

Característica de Qualidade: Completitude

1. As informaçōes contidas na descrição do produto também estăo incluidas no manual do usurário?

0. Năo

1. Algumas informaçōes

2. $\operatorname{sim}$

2. As informaçōes ausentes (que estão faltando) estão claramente 0 . Não, a informação ausente cuja ausência é óbvia, não identificadas na norma com relação a quando ou como a informaçāo tomar-se-á disponivel e será incluida no manual do usuário? está disponive

1.V A intormação ausente é fundamentai identlflca-la

2. Sim - a intormação da informação ausente é satlsfatória ou aparentemente nenhuma informaçăo está faltando

3. O manual do usuário possul exemptos de teias (menus, etc) que 0 . Năo. Somente figuras das telas principals são podertam ser encontradas durante a execução do sofware? mostradas

1. Figuras de telas, menus, etc, são mostrados mas seus conteúdos năo sāo mostrados

2. $\checkmark \operatorname{Sim}-0$ número e a qualidade das figuras de telas no manuai do usuário são satisfatórios

Caracteristica de Qualidade: Correção

4. As informaçōes contidas no manual do usuário estāo corretas, ou seja, sem ambiguldades e erros?

O. Nảo

1. Algumas informaçōes estão ambíguas

2. Sim, todas

\section{Caracteristica de Qualldade: Consistência}

5. Os documentos do manual do usuário nảo apresentam 0 . Quase sempre apresentam contradiçōes contradiçöes entre si e com a descriçäo do produto?

1. Usuaimente, mas nảo sempre

2. Geraimente nāo apresentam contradiçöes

6. A tabela do conteúdo está consistente com o conteúdo do manual com respelto à paginaçăo, títulos e numeraçå?

7. Quando a diretriz (norma) no manual do usuário, descreve funçōes especificas do software, são observadas se a funçāo executa como 0 esperado (ou seja, as consequênclas da execução da função, de fato, săo como as descritas no manual do usuário)?

8. Os termos definidos no manual do usuário estão explicados consistentemente?

0. Nấo ou nenhuma tabela de conteúdo fol encontrada 1. Menos do que 5 inconsistências foram encontradas 2.r Sim

O. Näo

1. Algumas funçōes executam como o esperado

2. Sim, todas as funçōes executam como o esperado

O. Nāo, geraimente näo

1.ฬ Usualmente, mas näo sempre

2. Sim, sempre

Caracteristica de Qualidade: Inteligibilidade

9. O manual do usuário está bem escrito e de fácil entendimento $0 . \checkmark \mathrm{Nảo}$. O manual está muito técnico para um leitor sem nenhum conhecimento (background) do sistema?

1. Algumas partes estáo dificeis de compreender

2. Sim, geraimente

Característica de Qualidade: Apresentacäo o Organizacão

10. O manual do usuário Inclui uma lista de referências para outros documentos importantes com relaçăo ao sistema atual?

0. Não

1. A lista do referẻncia está desestruturada / incompleta I dificil para usar

2. Sim, a lista de referência está suficientemente completa - proveltosa ou aparentemente, outros documentos nāo são essenciais para o entendimento do usuário com relacăo ao sistema

Muitas repetiços ou nenhuma definiça foi encontrada encontrados no texto ou essas definiçōes estảo incluidas nas referências?

1. Algumas repetiçöes

2. Referências para definiçőes únicas

12. O manual do usúário contém figuras, tabelas, etc, para explicar 0 . Năo melhor o conteúdo num grau satisfatório (aceitável)?

1. Figuras, etc, são usadas raramente

2. Flguras, etc, são usadas extensivamente 
Quadro 7.9 - Avaliação do Pacote de Software - Recursos Humanos (continuação)

\begin{tabular}{|c|c|}
\hline $\begin{array}{l}\text { REQUISITO DE QUALIDADE: PROGRAMAS E DADOS } \\
\text { Nota }\end{array}$ & Nota Maxima $=26 \quad$ Resultado $(\%)=85$ \\
\hline MEDIDAS & RESPOSTAS \\
\hline Característica de Qualidade: Funclonalidade & \\
\hline $\begin{array}{l}\text { 1. Existe um manual de instalação com instruçōes detalhadas para } \\
\text { o usuário realizar a instalação dos programas? }\end{array}$ & $\begin{array}{l}\text { O. Näo } \\
\text { 2.V Sim - ou aparentemente, a instalaçāo dos programas } \\
\text { näo é realizada pelo próprio usuário }\end{array}$ \\
\hline $\begin{array}{l}\text { 2. É possivel Instalar os programas segulndo as informaçōes } \\
\text { contidas no manual de instalaçăo? }\end{array}$ & \begin{tabular}{|l} 
Não \\
2. Sim - ou aparentemente, a Instalação dos programas \\
não é realizada pelo próprio usuário
\end{tabular} \\
\hline $\begin{array}{l}\text { 3. É possível veriflcar se uma instalação dos programas foi bem } \\
\text { sucedida? }\end{array}$ & \begin{tabular}{|l} 
O. Não \\
2. S Sim - ou aparentemente, a instalaçāo dos programas \\
nāo é realizada pelo próprio us uário
\end{tabular} \\
\hline $\begin{array}{l}\text { 4. O controle da operaçáco e do comportamento do programa pelo } \\
\text { usuário, por exemplo, mensagens, formatos de tela de entrada e } \\
\text { relatórios impressos estáo estruturados de maneira uniforme? }\end{array}$ & $\begin{array}{ll}\text { 0. Não } \\
\text { 1. Algumas informaçð̄es estão estruturadas } \\
\text { 2. Sim, todas }\end{array}$ \\
\hline $\begin{array}{l}\text { 5. Existe consistência de vocabulário entre as mensagens dos } \\
\text { programas e a documentaçăo? }\end{array}$ & $\begin{array}{ll}\text { O. Nảo } \\
\text { 2.r Sim }\end{array}$ \\
\hline Característica de Qualidade: Confiabilidade & \\
\hline $\begin{array}{l}\text { 6. Se os dados estiverem fora dos limites especiflcados, o usuáno } \\
\text { conseguirá controlar esse estado anormal sem perder dados? }\end{array}$ & $\begin{array}{ll}\text { 0. } & \text { Năo } \\
2 . \checkmark & \text { Sim }\end{array}$ \\
\hline Característica de Qualidade: Usabilidade & \\
\hline $\begin{array}{l}\text { 7. As mensagens de erro apresentam informaçōes necessárlas } \\
\text { para a solução da situaçăo de erro (por exemplo, uma referência } \\
\text { a um item no manual do usuário)? }\end{array}$ & $\begin{array}{|ll|}0 . \checkmark & \text { Não } \\
2 . & \text { Sim }\end{array}$ \\
\hline $\begin{array}{l}\text { 8. Existe identificaçāo da função do programa que está sendo } \\
\text { executada no momento? }\end{array}$ & $\begin{array}{l}\text { O. Näo } \\
\text { 1. Alguns programas exibem a identficicação da funçăo } \\
\text { que está sendo executada } \\
2 . \checkmark \text { Sim } \\
\end{array}$ \\
\hline $\begin{array}{l}\text { 9. As mensagens dos programas foram projetadas de forma que o } \\
\text { usuário possa diferenciá-las pelo tipo (por exemplo, mensagens } \\
\text { de confirmaçāo, consulta, advertêncla e erro)? }\end{array}$ & $\begin{array}{ll}0 . & \text { N5a } \\
2 . \checkmark \operatorname{Sim}\end{array}$ \\
\hline 10. Existe clareza nos formatos de telas de entrada e relatórios? & $\begin{array}{ll}0 . & \text { Nâo } \\
2 . \checkmark \text { Sim }\end{array}$ \\
\hline $\begin{array}{l}\text { 11. Na execuçāo de funçōes como apagar dados ou sobrepo-jos, } \\
\text { existe atertas claros para as consequências de uma determinada } \\
\text { confirmaçāo? }\end{array}$ & $\begin{array}{ll}\text { O. Nâo } \\
\text { 2. }\end{array}$ \\
\hline $\begin{array}{l}\text { 12. Pode-se interromper um processamento demorado sem Ter } \\
\text { consequências graves? }\end{array}$ & $\begin{array}{ll}0 . \checkmark & \text { Não } \\
2 . & \text { Sim }\end{array}$ \\
\hline Caracteristica de Qualidade: Auxilio (holp) & \\
\hline $\begin{array}{l}\text { 13. Está disponivel ateridimento on-line em caso de dúvida a respeito } \\
\text { do software produto? }\end{array}$ & $\begin{array}{l}\text { O. Nảo } \\
\text { 2. Sim }\end{array}$ \\
\hline
\end{tabular}


Para realizar o julgamento foi necessário completar o Quadro 7.10. Para isso, transcreveu-se as necessidades do cliente (obtido em percentual na última linha da matriz da Tabela 7.8 da seção 7.3.1) para a respectiva coluna de "ñecessidades do cliente(\%)". Em seguida, transcreveu-se o resultado (obtido da avaliação do pacote do Quadro 7.9 da seção anterior) para a respectiva coluna "resultado(\%)". Finalmente, multiplicou-se o valor da coluna "necessidades do cliente" pelo valor em percentual da coluna "resultado(\%)", obtendo-se a coluna "proporção".

Quadro 7.10 - Comparaçāo das Necessidades do Cliente versus Avaliação do Pacote do Recursos Humanos

\begin{tabular}{|c|c|c|c|}
\hline $\begin{array}{c}\text { Características de Qualidade } \\
\text { de Pacote de Software }\end{array}$ & $\begin{array}{c}\text { Necessidades } \\
\text { do Cliente (\%) }\end{array}$ & \multicolumn{2}{|c|}{ Avallaçăo do Pacote } \\
\cline { 3 - 4 } & & Resultado(\%) & Proporçăo \\
\hline Descriçäo do Produto & 51,32 & 54 & 27,71 \\
\hline Manuai do Usuário & 15,21 & 71 & 10,8 \\
\hline Program as e Dados & 33,47 & 85 & 28,45 \\
\hline Valor Medido & $100 \%$ & & $66,96 \%$ \\
\hline
\end{tabular}

Para interpretar o Quadro acima deve-se comparar os valores que estão na coluna "necessidades do cliente" com os valores que estão na coluna "resultado(\%)". Por exemplo, analisando-se os valores da penúltima linha, as necessidades do cliente com relação a característica de pacote de software "programas e dados" foi $33,47 \%$ e o pacote avaliado atendeu $85 \%$. Proporcionalmente, obteve-se 28,45 dos 33,47 exigidos pelo cliente. Pode-se notar que na avaliação do pacote, a característica de qualidade programas e dados é a que está mais próxima das necessidades do cliente.

Somando-se os valores que estão na coluna "proporção", obtem-se $66,96 \%$ para o valor medido que se refere ao resultado da avaliação do pacote de software do Setor de Recursos Humanos.

Como não houveram outros pacotes de administração de recursos humanos para serem analisados, o cliente foi questionado sobre sua satisfação com relação ao pacote vetorh. Segundo o cliente, ele está satisfeito com o pacote vetom, o que corresponde com o resultado obtido de $66,96 \%$ do atendimento do pacote com relação as suas reais necessidades. 


\section{4 - Consideraçōes Finais}

Neste capitulo foram apresentados dois estudos de caso para exemplificar o procedimento para escolha de pacote de software na área de Sistemas de Informação.

No capítulo a seguir são apresentadas as conclusōes deste trabalho, bem como futuros desenvolvimentos que podem advir do mesmo. 


\section{CAPÍTULO 8 - CONCLUSÕES}

\section{1 - Conclusões}

Este trabalho teve como objetivo apresentar um procedimento para escolha de pacote de software na área de Sistemas de Informação. O que motivou o desenvolvimento do procedimento foi a dificuldade que as pessoas enfrentam quando desejam comprar um pacote de software ${ }^{1}$ de sistemas de informação que atenda suas necessidades específicas. Atualmente existem diferentes pacotes de software para aplicações similares em sistemas de informação. São inúmeras as opções quando se deseja adquirir, por exemplo, um sistema de contas a pagar, controle de estoque, contabilidade, etc.

A existência dessas muitas opçōes deve-se ao fato de que o uso do computador nas atividades diárias das pessoas tem crescido substancialmente, o que motiva as "software houses" a desenvolver cada vez mais sistemas especificos que atendam a essas atividades.

Diante de tantas opções, qual pacote escolher? Como saber qual pacote atende melhor as necessidades da aplicação? Qual característica do pacote è mais importante?

\footnotetext{
${ }^{1}$ Um pacote de software envolve um conjunto completo e documentado de programas fornecidos a diversos usuários para uma aplicação ou função genérica.
} 
No que se refere à tradução dos desejos do cliente para requisitos de pacote, utilizouse uma abordagem do programa de Gerenciamento da Qualidade Total (TQM), geralmente utilizada em ambiente de manufatura tradicional. Essa abordagem denomina-se Quality Function Deployment (QFD) $\theta$, apesar da mesma ser direcionada originalmente para desenvolvimento, neste trabalho ela foi adaptada para auxiliar a escolha de um pacote de software. A adaptação foi efetuada, inicialmente, na utilização apenas da primeira matriz - a matriz Casa da Qualidade, sendo que o QFD é composto de quatro matrizes. A segunda adaptação foi efetuada nas colunas da matriz Casa da Qualidade, nas quais foram fixadas as caracteristicas de qualidade para pacote de software, estabelecidas pela norma NBR 12119 da ABNT.

Para auxiliar o preenchimento das linhas da matriz Casa da Qualidade, que correspondem às necessidades do cliente e respectivas prioridades, instanciou-se um processo de aquisição de conhecimento (IPAIA), desenvolvido no ICMC [Jubileu, 1999] para o domínio QFD - Casa da Qualidade.

Estabelecidas as diretrizes para ajudar a tradução das necessidades do cliente em requisitos de qualidade de pacote, ficou ainda o problema de como avaliar os diversos pacotes disponiveis para a mesma aplicação, visando uma escolha adequada. Criou-se então neste trabalho, uma proposta de métricas que permitem, através de questionários, que os pacotes sejam avaliados.

O julgamento da escolha do pacote, proposto neste trabaiho, utilizou o resultado obtido na matriz Casa da Qualidade, que expressam as necessidades do cliente e o resultado dos questionários que mostra a qualidade de cada pacote avaliado.

\section{2 - Contribuições deste Trabalho}

Durante o andamento deste trabalho, constatou-se que, de fato, existe a necessidade de um procedimento para escolha de pacote de software na área de sistemas de informação, devido ao grande número de opções de pacote de software nessa área. Nesse sentido, o processo de aquisição de conhecimento IPAIA, instanciado para o domínio QFD - Casa da Qualidade, facilitou a obtenção das necessidades do cliente com relação às características de pacote de software, permitindo também que essas características fossem priorizadas sob o ponto de vista do cliente. 
Outro aspecto importante, que ajudou o usuário na escolha, foi a criação de métricas ${ }^{2}$ para aplicar na avaliação de pacotes de software, possibilitando assim, realizar uma comparação entre as reais necessidades do cliente e as caracteristicas que os pacotes oferecem. A partir desse resultado o cliente teve condiçöes de tomar uma decisão sobre qual pacote escolher.

Para validar o procedimerito proposto neste trabalho, realizou-se dois estudos de caso e dessa experiência constatou-se que a sessão de brainstorming estruturado, realizada para obter as necessidades do clierite, foi importante no direcionamento das idéias para as características de qualidade de pacote. O usuário, ao mesmo tempo que pôde expor suas idéias livremente, teve também uma orientação para que se expressasse especificamente com relação a fatores importantes de pacotes de software. Isso reduziu o tempo da sessão, sem reduzir os limites da imaginação.

Da matriz Casa da Qualidade diversos resultados podem ser extraídos se considerado, independeritemerite, o relacionamento das características de descrição do produto, manual do usuário e programas e dados com as necessidades do cliente:

- Da relação necessidades do cliente com a característica de qualidade descrição do produto, pode-se realizar indicações para o designer da embalagem do pacote de software;

- Considerando-se a relação necessidades do cliente com a característica de qualidade manual do usuário, pode-se realizar indicaçōes para a criação de documentos;

- Finalmente, considerando-se a relação necessidades do cliente com a caracteristica de qualidade programas e dados, pode-se obter os requisitos para desenvolvimento de um software que atenda melhor as necessidades do cliente.

\section{3 - Trabalhos Futuros}

A partir dos resultados deste trabalho, outros projetos podem ser desenvolvidos:

- Como nos dois estudos de caso realizou-se a avaliação de apenas um pacote de software, tanto na área de cantinas como na área de administração de recursos humanos, é interessante que se faça a avaliação para vários pacotes de software da mesma aplicaçăo, para que o procedimento seja melhor validado;

\footnotetext{
${ }^{2}$ Questionário desenvolvido com base nas subcaracteristicas de qualidade de pacote de software estabelecidas pela norma NBR 12119
} 
- Visto que nas métricas propostas, cada característica de qualidade (descrição do produto, manual do usuário, programas e dados) teve o mesmo grau de importáncia na avaliação do pacote, poderia ser feita uma extensão das métricas, incluindo-se um peso para cada uma das subcaracterísticas;

- Como a ferramenta QFDT utilizada para construir as matrizes Casa da Qualidade dos dois estudos de caso não atendeu todo o processo de aquisição de conhecimento IPAIA, instanciado para o domínio QFD - Casa da Qualidade, poderia ser desenvolvida uma ferramenta QFD direcionada especificamente para o uso desse processo;

- Também seria interessante desenvolver uma ferramenta que possibilitasse automatizar as métricas propostas, facilitando a resposta dos questionánios e a conclusăo da qualidade do pacote;

- Para facilitar a comparação entre as necessidades do cliente e os pacotes avaliados, as duas ferramentas citadas acima deveriam ser integradas, para que fosse possivel realizar a escolha do pacote. 


\section{REFERÊNCIAS BIBLIOGRÁFICAS}

[Akao, 1990]

[Akao, 1996]

[Andert, 1999]

[ASI, 1995]

[ASI, 1999]
AKAO, Y., Quality Function Deployment: Integrating Customer Requirements into Product Design, Portland: Productivity Press, 1990.

AKAO, Y., Introdução ao Desdobramento da Qualidade, Tradução de Zelinda Tomie Fujikawa e Seiichiro Takahashi, Belo Horizonte, UFMG, Escola de Engenharia, Fundaçăo Christiano Ottoni, 1996 viii, $187 p$.

ANDERT, Ed. P. Jr. Expert System Software Verification, Validation and Test. Published in: ASQC Proceedings of the Second International Conference on Software Quality, 1992, [on line], [10/03/1999], Disponivel na internet:

<http://www.consys.com/publications/w test.html >

AMERICAN SUPPLIER INSTITUTE (ASI), Quality Function Deployment for Products: Implementation Manual, Dearbom, 1995. AMERICAN SUPPLIER INSTITUTE (ASI), Quality Function Deployment, [on line], [11/02/1999], Disponivel na intemet: $<$ http://mwn.asiusa.com/QFD/> 
[Becker, 1998]

[Bouchard, 1999]

[Carvalho, 1997]

[Cheng, 1995]

[Cohen, 1937]

[Cooke, 1994]

[Dean, 1994a]

[Eureka, 1992]

[Gootinalake \& Khebbal, 1995]

[Gremba \& Myers, 1998]
BECKER ASSOCIATES, Quality Function Deployment, [on line], [11/04/1999], Disponível na internet:

\section{$<$ http://www.becker-associates.com/tocafd.htm>}

BOUCHARD, T. J. "Whatever Happened to Brainstorming?" In Guide to Creative Action, 1977, [on line], [19/05/1999], Disponivel na internet: <http://www.rla.unc.edu/lessons/brain rules.htm>

CARVALHO, MARLY M. DE, QFD - Uma Ferramenta de Tomada de Decisão em Projeto, Tese de Doutorado, UFSC, Florianópolis, 1997, 162p.

CHENG, L. C.; e outros, QFD: Planejamento da qualidade, Belo Honizonte, UFMG, Escola de Engenharia, Fundaçăo Christiano Ottoni, 1995, 262p.

COHEN, L., Quality Function Deployment: how to make QFD work for you, Addison-Wesley Publishing Company, 1937.

COOKE, N. J. Varieties of knowledge elicitation techniques. International Joumal of Human-Computer Studies, v. 41, n. 6, p. 801-849, 1994.

DEAN, EDWIN B., The Voice of the Customer, [on line], [11/11/1998], Disponivel na internet:

$<$ http://mijuno.larc.nasa.gov/dfc/qfd/voc.html>

EUREKA, W. E.; RYAN, N. E., QFD: Perspectivas gerenciais do desdobramento da função qualidade, Tradução de Maria Júlia Pereira Quintella, Rio de Janeiro, Qualitymark Ed., 1992.

GOONATILAKE, S. KHEBBAL, S. Intelligent Hybrid Systems: Issues, Classifications and Future Directions (Chapter 1). Intelligent Hybrid Systems, Edited by S. Goonatilake and S. Khebbal, John Wiley \& Sons Ltd, 1995.

GREMBA, J.; MYERS, C. The IDEAL Process Model: A Practical Guide for Improvement, in: [on line], [25/08/1998], Disponivel na internet: <http://www.sei.cmu.edu/activities/ideal/ideal.bridge.html> 
[Haag, 1996]

[Hauser, 1988]

[ISO/IEC 9126, 1991]

[Jubileu, 1999]

[Kano, 1984]

$[\mathrm{KCl}, 1999]$

(Kidd, 1987)

[King, 1987]

[King, 1989]

[Mazur, 1998]

[MCGraw \& Briggs, 1989]

[NBR 12119, 1996]
HAAG, S.; RAJA, M. K.; SCHKADE, L. L., Quality Function Deployment Usage in Software Development, Communications of the $A C M$, v. 39, n. 1, p. 41-49, janeiro, 1996.

HAUSER, JOHN R.; CLAUSING, D., The House of Quality, Harvard Business Review, p. 63-73, maio-junho, 1988.

ISO/IEC 9126, Information Technology - Software Product Evaluation - Quality characteristics and guidelines for their use, junho, 1991.

JUBILEU, Andrea Padovan, Aquisiçăo de Conhecimento Como Apoio ao Método de Engenharia Reversa FUSION-RE/l, Dissertação de Mestrado, ICMC-USP, 1999, 140p.

KANO, N.; e outros, "miryokuteki Hinshitsu to Atarimae Hishitsu" (Qualidade Atrativa e Qualidade Óbvia) Hinshitsu, Vol. 14, n. 2, p. 39-48, fevereiro, 1984.

$\mathrm{KCl}$ - Kanten Communications International. The Basic Rules of Brainstoming, [on line], [19/05/1999], Disponivel na internet: <http://www.kanten.com/RBWV/bsrules.html>

KIDD, A.L. Knowledge Acquisition for Expert Systems. Plenum Press - New York and London, 1987.

KING, R., Listening to the Voice of the Customer: Using the Quality Function Deployment System, National Productivity Review, p. 277281, 1987.

KING, B., Better Designs in half the time: Implementation Quality Function Deployment in America, GOALQPC, Methuen, 1989.

MAZUR, GLEN, QFD FAQ, [on line], [29/10/1998], Disponivel na internet:

$<$ http://hww-personal.engin.umich.edu/ qmazur/afd.htm>

MCGRAW, K.L.; BRIGGS, K.H. Knowledge Acquisition - Principles and Guidelines. Prentice-Hall, 1989.

NBR 12119, Tecnologia de Informação - Pacotes de Software Teste e requisitos de qualidade - Versão brasileira baseada na norma ISO/IEC 12119/1994, agosto, 1996. 
[NBR ISO/IEC 9126, 1994]

[Ohfuji, 1997]

[Osbome, 1999]

[Peixoto, 1998]

[Pressman, 1994]

[Rezende \& Pugliesi, 1998]

[Shindo, 1998]

[Shindo, 1999]

[Silva, 1998]

[Tuthill, 1990]

[Wilson, 1999]
NBR ISO/IEC 9126, Tecnologia de Informação - Avaliação de Produto de Software - Caracteristicas de Qualidade e Diretrizes para o seu uso - Versão brasileira baseada na norma ISO/IEC 9126/1991, agosto, 1994.

OHFUJI, T.; e outros, Métodos de Desdobramento da Qualidade, Tradução de Zelinda Tomie Fujikawa, Belo Horizonte, UFMG, Escola de Engenharia, Fundação Christiano Ottoni, 1997, 256p. it.

OSBORNE. Generic Brainstorming Rules, Henley Management College, [on line], [19/05/1999], Disponivel na internet: $<$ http://www.henleymc.ac.uk/research/creat $01 . h t m>$

PEIXOTO, M. O. DA CUNHA, Uma proposta de aplicação da metodologia desdobramento da função qualidade (QFD) que sintetiza as versões QFD-estendido e QFD das quatro ênfases, Dissertação de Mestrado, EESC-USP, 1998, 148p.

PRESSMAN, R. S., Software Engineering - A Practitioner's Approach, Edição Européia, McGraw-Hill, 1994.

REZENDE, S. O; PUGLIESI, J. B. Aquisição de Conhecimento Explicito ou Manual. Notas do ICMSC, n. 37, março, 1998.

SHINDO Laboratory, Quality Function Deploymenbt, Yamanashi University, [on line], [31/05/2000], Disponivel na internet: $<$ http://www.is.esi.vamanashi.ac.jp/Int $1 /$ services/gfd/>

SHINDO, Hisakazu, Application of QFD to Software Development and QFD Software Tools, $5^{\text {th }}$ intemational Symposium on Quality Function Deployment, Belo Horizonte, MG, agosto, 1999.

SILVA, L. A., Qualidade de Software: Manifestações aos Clientes, Developers Magazine, 1998.

TUTHILL, G. S. Knowledge Engineering: Concepts and Practices for Knowledge-Based System. TAB - Books Inc., 1990.

WILSON, Michael. Knowledge Acquisition: The current position. Science and Engineering Research Council. Rutherford Appleton Laboratory, [on line], [14/01/1999], Disponivel na internet: $<$ http://www.dci.clrc.ac.uk/ActivityPublications/92> 


\section{BIBLIOGRAFIA COMPLEMENTAR}

[Abbot, 1955]

[Andrade, 1996]

[Broh, 1974]

[Crosby, 1979]

[Dean, 1994b]

[Delta, 1994]

[Delta, 1999a]

[Delta, 1999b]
ABBOT, L., Quality and Competion, Nova York, Columbia University Press, 1955.

ANDRADE, Ana Luísa P., e outros, Aplicação da Norma ISO/EC 12119 na Avaliação da Qualidade de Produtos de Software, VII Conferência Intemacional de Tecnologia de Software, junho, 1996. $\mathrm{BROH}$, R. A., Managing quality for higher profits, Nova York, McGraw-Hill, 1974.

CROSBY, P. B., Quality is free, Nova York, McGraw-Hill, 1979.

DEAN, EDWIN B., Quality Function Deployment, [on line], [11/11/1998], Disponivel na internet:

<http://mijuno.larc.nasa.gov/dfc/afd/afd.html>

DELTA, Hans Kyster, MicroScope - The Evaluation of Software Product Quality, versão 2.02.A, fevereiro, 1994.

DELTA Software Engineering, [on line], [02/09/1999], Disponivel na internet: <http://www.delta.dk/se/scope/usabilit.htm>

DELTA Software Engineering, [on line], [02/09/1999], Disponivel na internet: <http://www.delta.dk/se/scope/sub-char.htm> 
[Delta, 1999c]

[Delta, 1999d]

[Endo, 1998]

[Erikkson, 1993]

[ISO/IEC 9126-2, 1995]

[ITI, 1998]

[Juran, 1974]

[Leffler, 1982]

[Nurna, 1999]

[Oliveira, 1994]

[Paladini, 1990]

[Tsukumo, 1996]
DELTA Software Engineering, [on line], [02/09/1999], Disponivel na internet: <http://www.delta.dk/se/scope/support.htm>

DELTA Software Engineering, [on line], [02/09/1999], Disponivel na internet: <http://www.delta.dik/se/scope/ecq.htm>

ENDO, C., Uma Estratégia para Iniciar Melhoria de Processo de Software, Dissertação de Mestrado, ICMC-USP, 1998, 95p.

ERIKKSON, I.; MCFADDEN, F., Quality Function Deployrnent: a Tool to Improve Software Quality, Information and Software Technology, v. 35, n. 9, p. 491-498, seternbro, 1993.

ISO/IEC 9126-2, Information Technology - Software Quality Characteristics and Metrics - Extemal Metrics, abnil, 1995.

INTERNATIONAL TECHNEGROUP INCORPORATED (ITI), The Basics of QFD, [on line], [11/11/1998], Disponivel na internet:

$<$ http:/hwww.titi-oh.corn/cppd/qfd/s

JURAN, J. M.; e outros, Quality control handbook, Nova York, McGraw-Hill, 1974.

LEFFLER, K. B., Ambiguous changes in product quality, Arnerican Economic Review, 1982, p. 956-967.

NUCLEO DE MANUFATURA AVANÇADA (NUMA), Quality Function Deployment, [on line], [20/04/1999], Disponivel na internet: $<$ http://www.numa.org.brl>

OLIVEIRA, M. A. L. DE, Qualidade: o desafio da pequena e média empresa, Rio de Janeiro, Qualityrnark Ed., 1994.

PALADINI, E. P., Controle de Qualidade - Uma Abordagem Abrangente, Editora Atlas AS, 1990.

TSUKUMO, Alfredo N.; e outros, Avaliação Incrernental de Qualidade de Produto de Software baseada na ISO/EC 9126 (NBR 13596), X Simpósio Brasileiro de Engenharia de Software, 1996. 


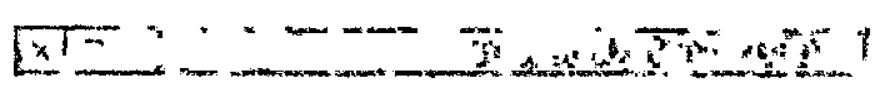

\section{APÊNDICE A - QUALITY FUNCTION DEPLOYMENT TOOL (QFDT)}

A ferramenta QFDT (Quality Function Deployment Tool) foi desenvolvida no laboratório Shindo da Universidade de Yamanashi no Japão. O projeto da ferramenta foi desenvolvido pelo Professor-Hisakazu-Shindo-e-implementado-pelo-Sr-Yanarso-Anang- $\theta_{\text {, }}$ resultado do estudo e desenvolvimento da ferramenta QFDT foi apresentado no Simpósio Internacional do QFD em agosto de 1998 em Sydney [Shindo, 1998; Shindo, 1999].

O desenvolvimento da ferramenta QFDT tem como objetivo suprir todas as necessidades do QFD, uma vez que, as ferramentas existentes no mercado não atendem a todos os conceitos do QFD.

A seguir apresenta-se as telas que foram utilizadas da ferramenta QFDT para a elaboração da matriz Casa da Qualidade para os estudos de casos 1 e 2: 
- A Figura A.1 mostra a interface gráfica da ferramenta QFDT para exibição das opçōes disponiveis:

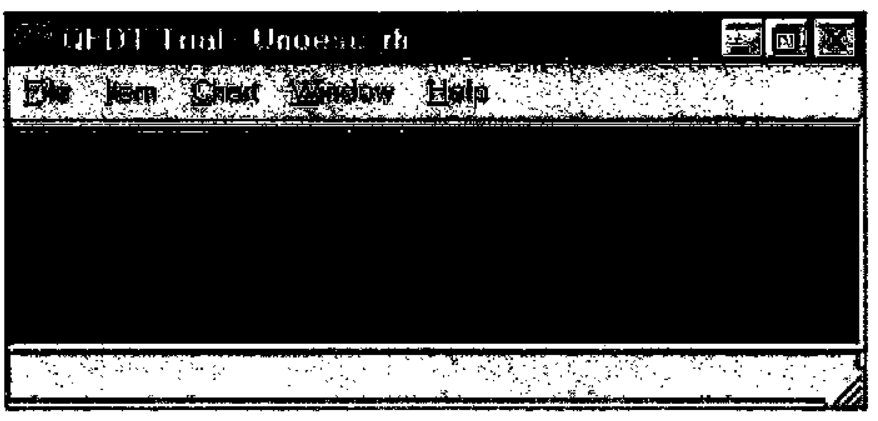

Figura A.1 - Exibição da Interface Gráfica Principal

- A Figura A.2 mostra as informações disponíveis para a Qpção "File". Essa opção permite criar um arquivo novo, abrir um arquivo já existente, salvar um arquivo ou sair da ferramenta.

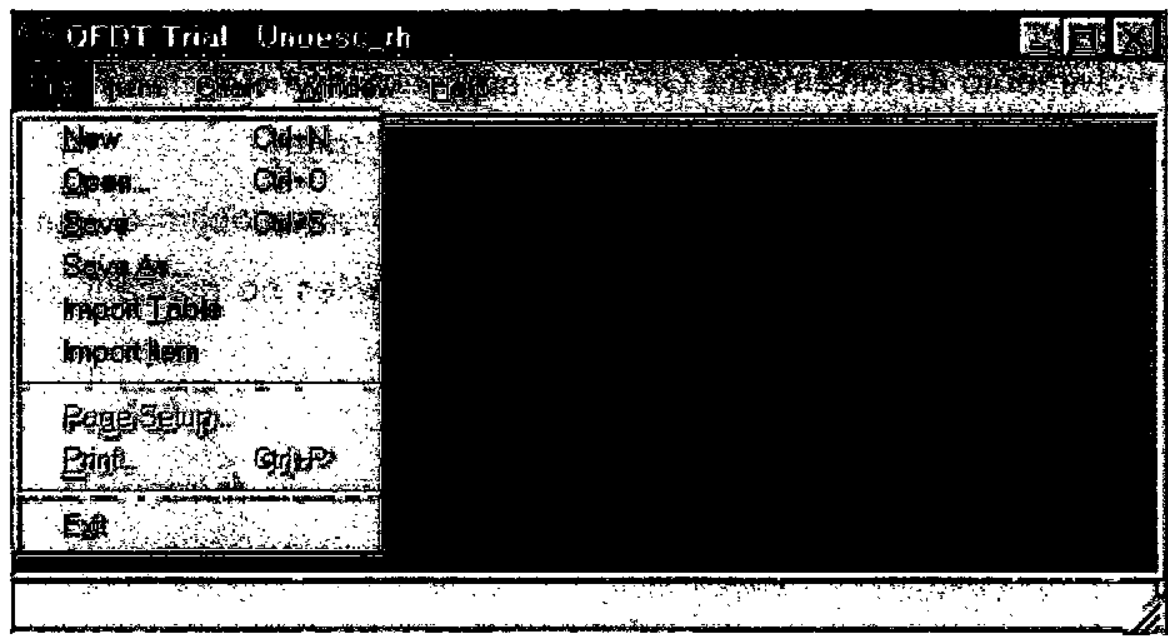

Figura A.2 - Escolha da opçăo para acessar informaçס̄es do "File" 
- A Figura A.3 apresenta as informações disponiveis para a opção "Item" .

Essa opção permite acessar informações sobre "Quality", "Element", "Cost", etc.

Dentro do contexto deste trabalho utiliza-se apenas as informações referentes a

"Quality" e "Element".

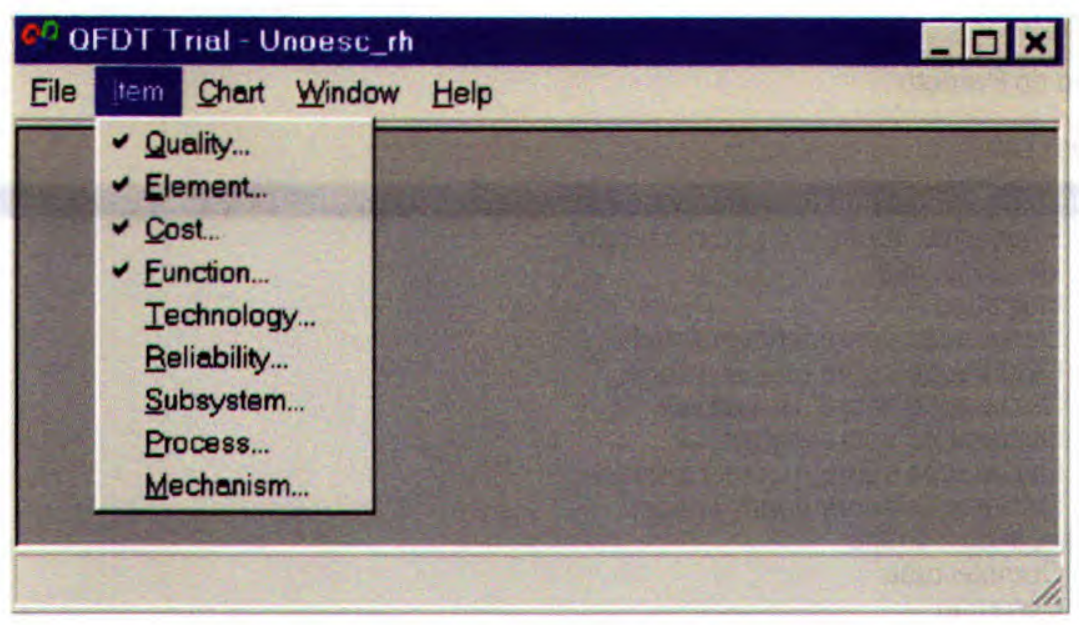

Figura A.3 - Escolha da opção para acessar informações do "Item"

- Figura 4 possibilita inserir, alterar, excluir ou consultar informações sobre a opção "Quality", ou seja, são informações sobre os requisitos do cliente.

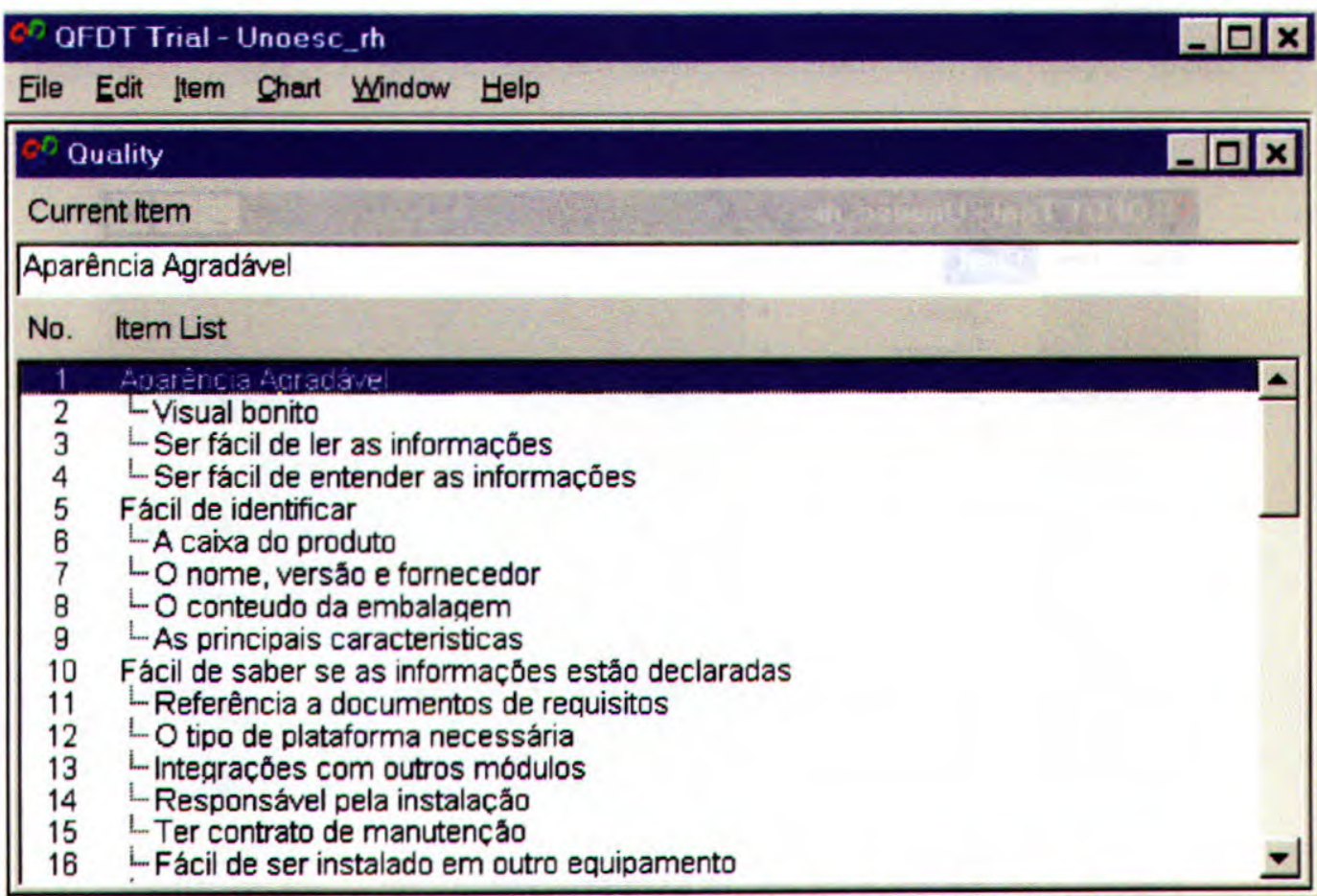

Figura A.4 - Interface Gráfica das informações "Quality" 
- A Figura A.5 possibilita inserir, alterar, excluir ou consultar informações sobre a opção "Element", ou seja, são informações sobre os requisitos de produto. Os requisitos de produto representam as características de pacote de software.

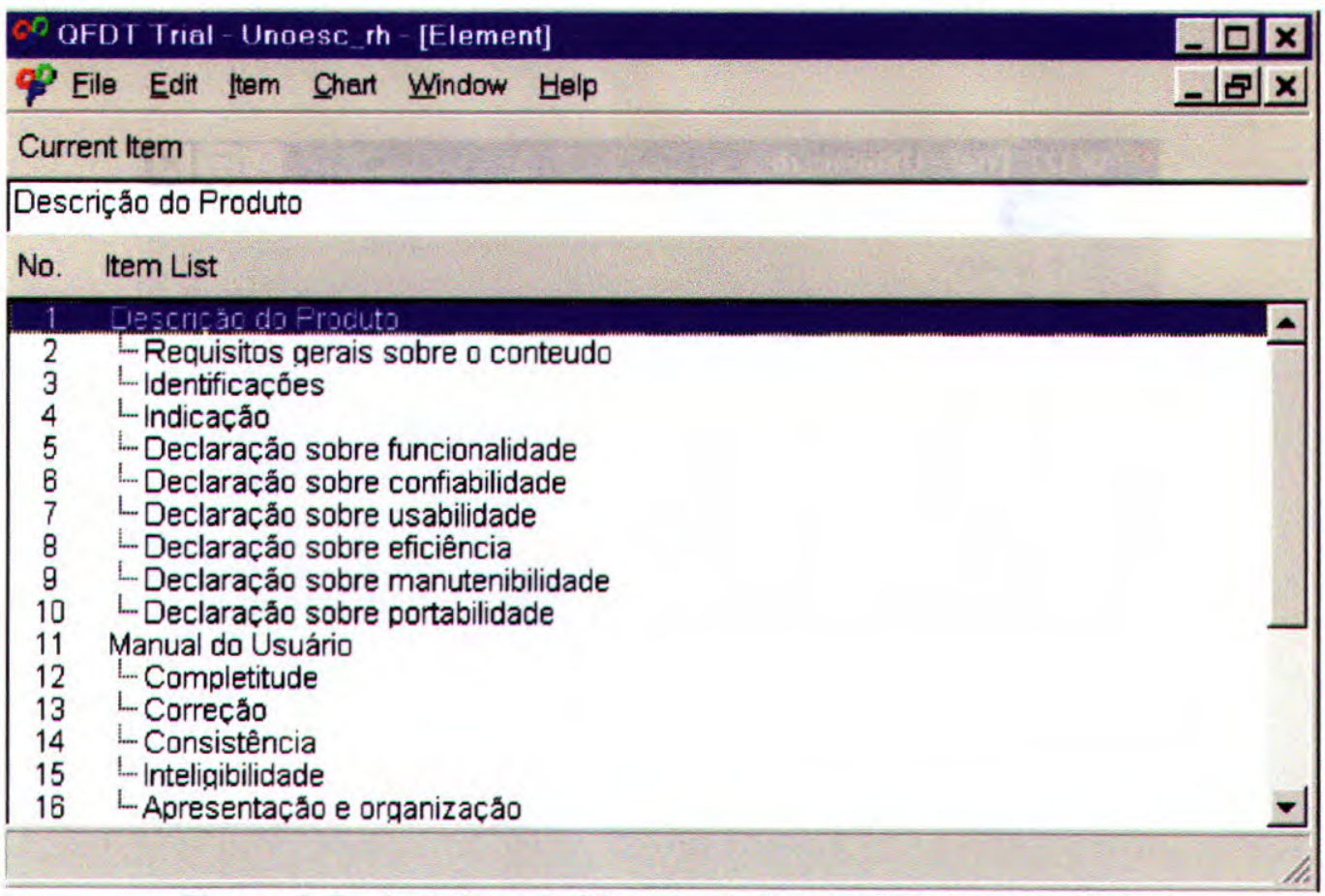

Figura A.5 - Interface Gráfica das informações "Element"

- A Figura A.6 apresenta as informações disponiveis para a opção "Chart" .

Essa opção permite relacionar informações sobre "Quality", "Element", "Cost", etc. Possibilita também acessar informações sobre "Quality Planning".

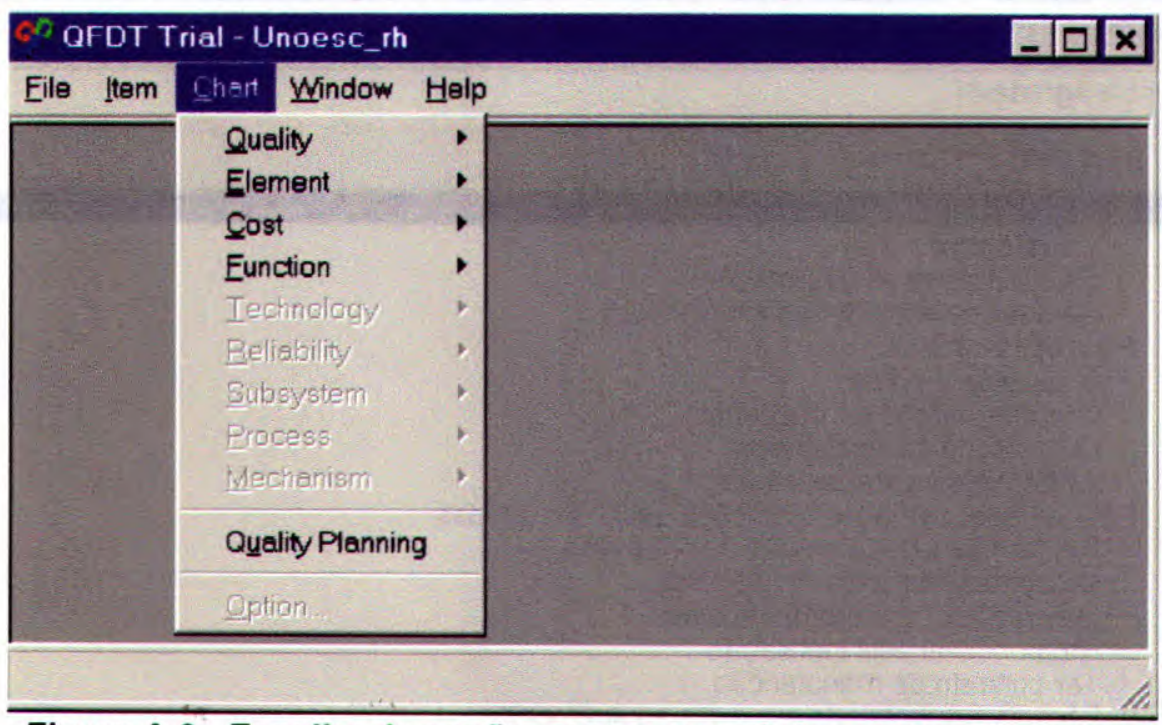

Figura A.6 - Escolha da opção para acessar informações do "Chart" 
- A Figura A.7 mostra a interface gráfica para acessar informações do "Quality Planning". Dentro do contexto deste trabalho insere-se informações sobre o grau de importância dos requisitos do cliente.

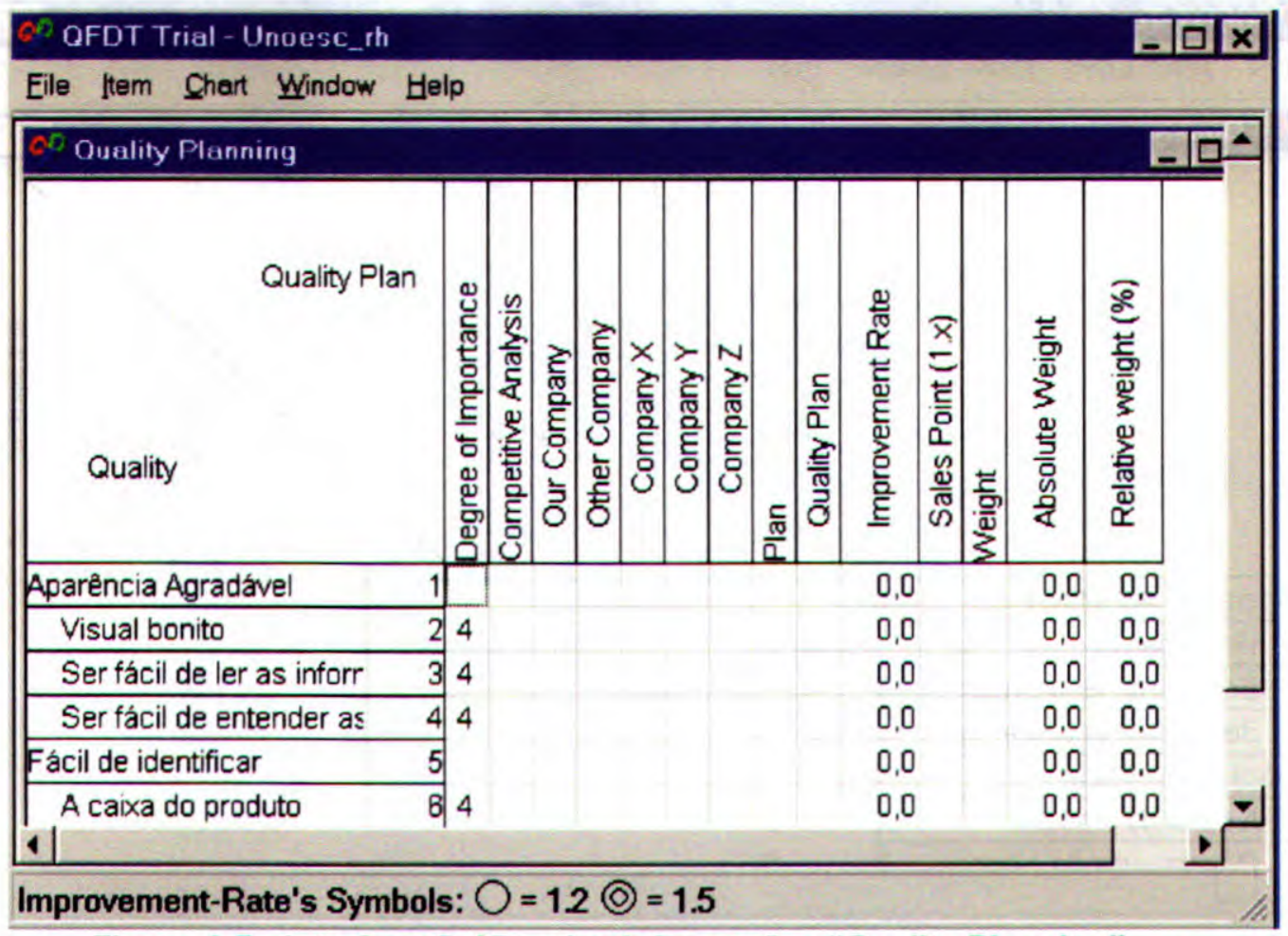

Figura A.7 - Interface Gráfica das informações "Quality Planning"

- A Figura A.8 apresenta informações para a escolha dos diversos relacionamentos entre "Quality", "Element", "Cost”, etc. Dentro do contexto deste trabalho, utilizase o relacionamento entre "Quality" e "Element", ou seja, relaciona-se os requisitos do cliente com as características de pacote de software.

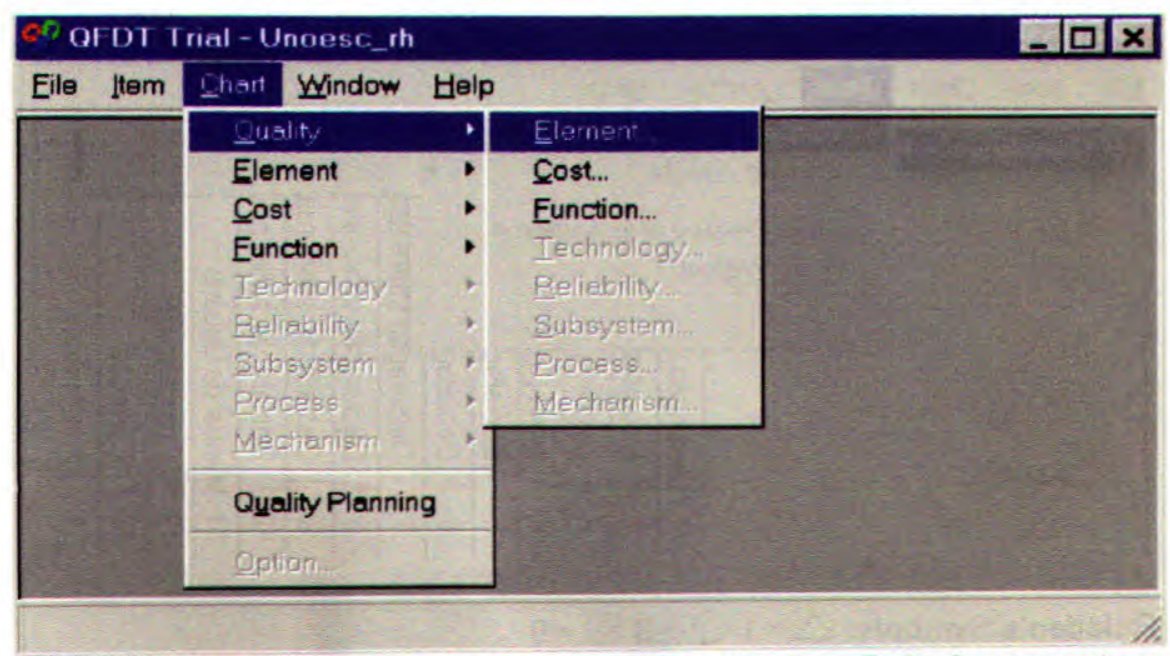

Figura A.8 - Interface Gráfica para Determinar os Relacionamentos 
- A Figura A.9 apresenta a interface gráfica para determinar os relacionamentos entre os requisitos do cliente ("Quality") e as características de pacote de software ("Element").

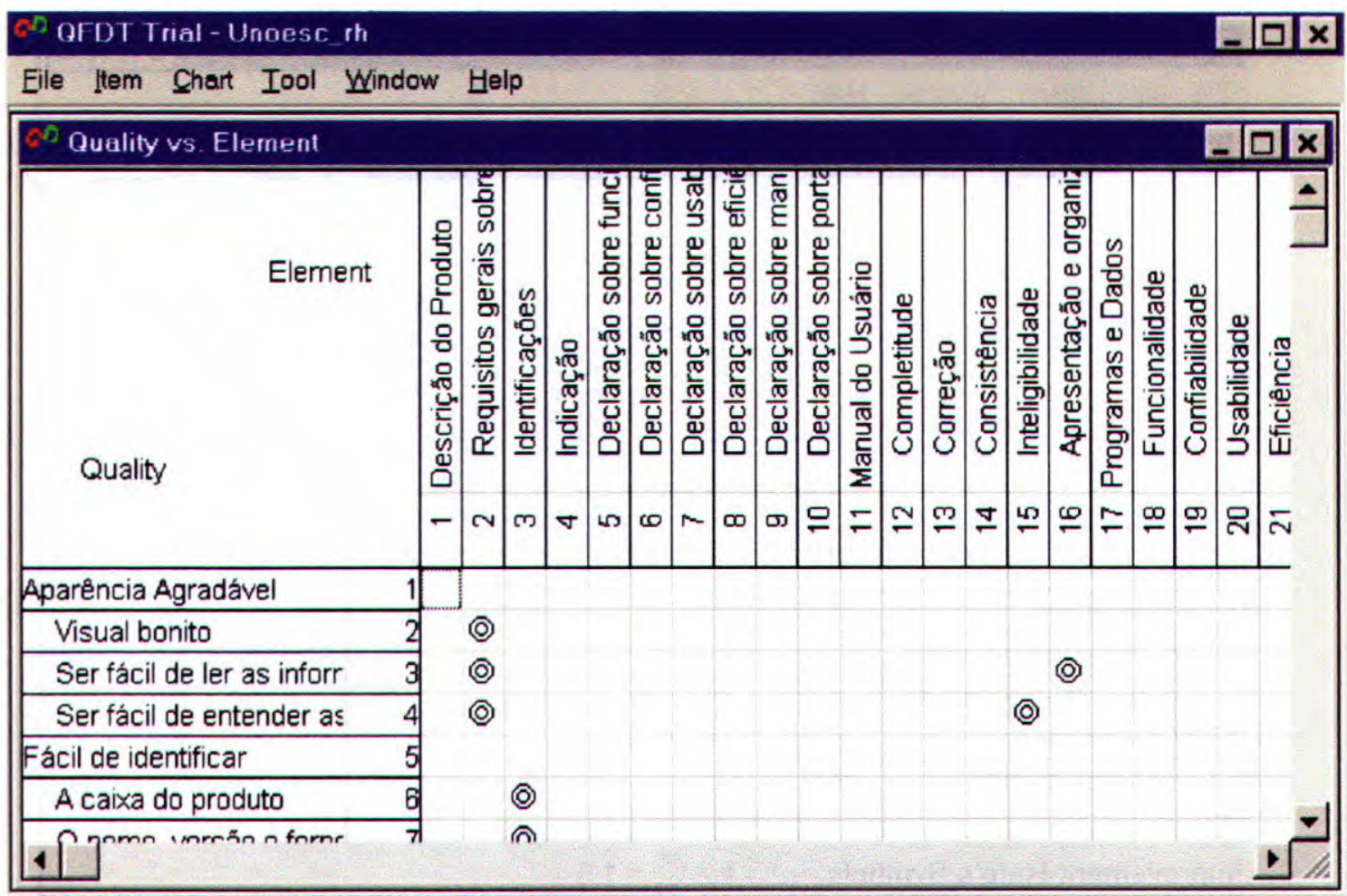

Relation's Symbols: $\triangle=1 O=3(0)=9$

Figura A.9 - Interface Gráfica entre os relacionamentos "Quality" e "Element"

- A Figura A.10 apresenta as informações disponíveis para a opção "Toll". Dentro do contexto deste trabalho utiliza-se a conversão do grau de importância.

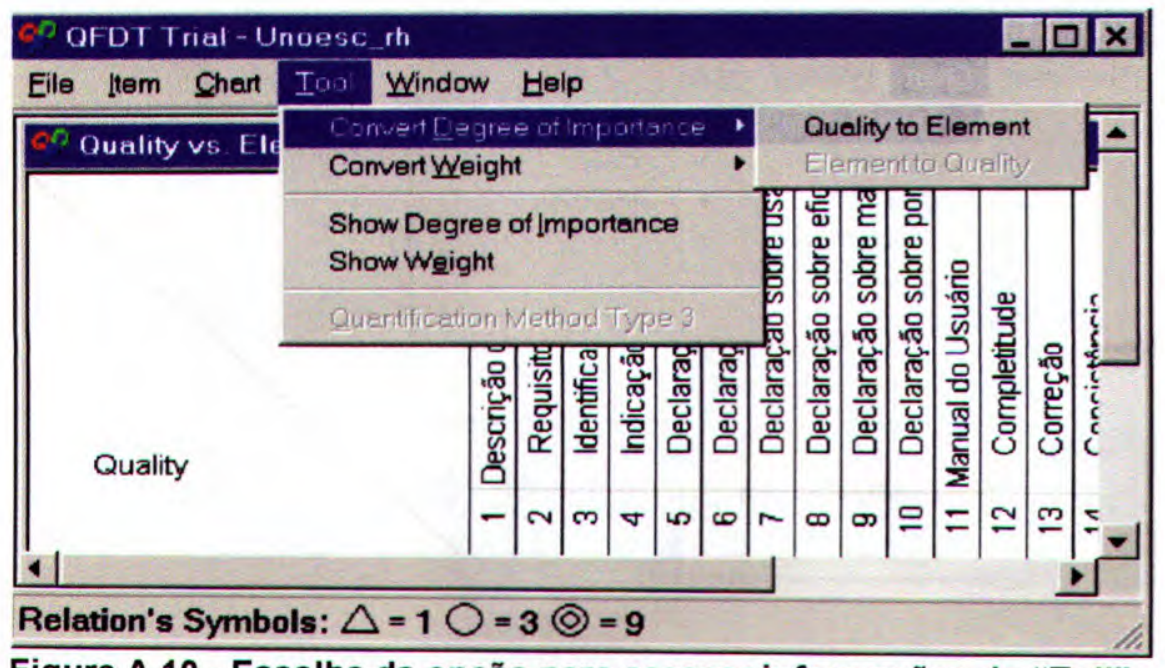

Figura A.10 - Escolha da opção para acessar informações do "Toll" 
- A Figura A.11 mostra a matriz Casa da Qualidade e calcula o grau de importância das características de pacote de software.

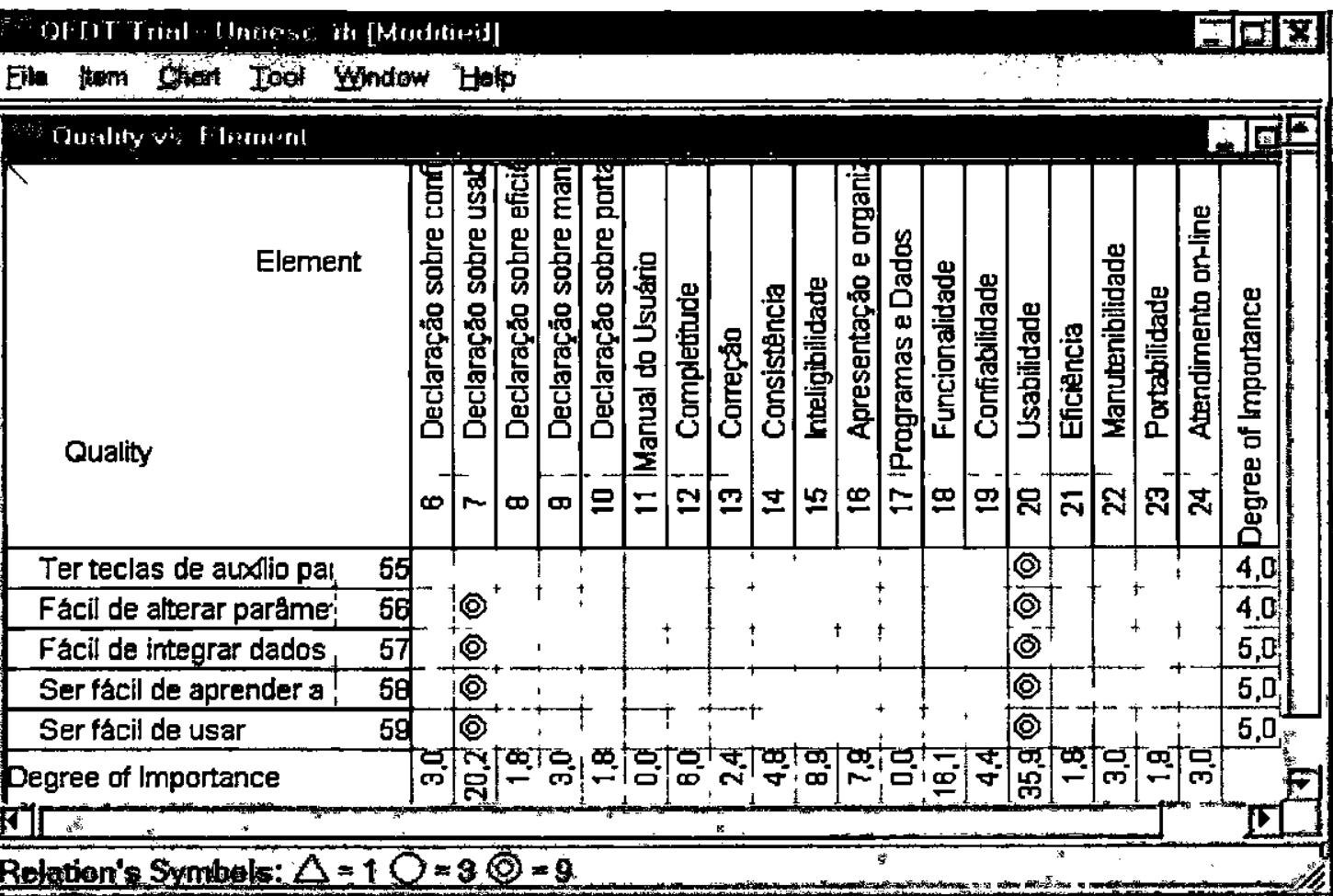

Figura A.11 - Edição da matriz Casa da Qualidade 
